Contract No. W-7405-eng-26

OPERATIONS DIVISION

Radioisotope Department

\title{
OAK RIDGE NATIONAL LABORATORY SHIPPING CONTAINERS FOR RAD IOACTIVE MATERIALS
}

R. W. Schaich

Date Published: May 1980

NOTICE This document contains information of a preliminary nature. It is subject to revision or correction and therefore does not represent a final report.

\author{
OAK RIDGE NATIONAL LABORATORY \\ Oak Ridge, Tennessee 37830 \\ operated by \\ UNION CARBIDE CORPORATION \\ for the \\ DEPARTMENT OF ENERGY
}


Printed in the United States of America. Available from National Technical Information Service

U.S. Department of Commerce

5285 Port Royal Road, Springfield, Virginia 22161

NTIS price codes-Printed Copy: A10 Microfiche A01

This report was prepared as an account of work sponsored by an agency of the United States Government. Neither the United States Government nor any agency thereof, nor any of their employees, makes any warranty, express or implied, or assumes any legal liability or responsibility for the accuracy, completeness, or usefulness of any information, apparatus, product, or process disclosed, or represents that its use would not infringe privately owned rights. Reference herein to any specific commercial product, process, or service by trade name, trademark, manufacturer, or otherwise, does not necessarily constitute or imply its endorsement, recommendation, or favoring by the United States Government or any agency thereof. The views and opinions of authors expressed herein do not necessarily state or reflect those of the United States Government or any agency thereof. 


\section{DISCLAIMER}

This report was prepared as an account of work sponsored by an agency of the United States Government. Neither the United States Government nor any agency Thereof, nor any of their employees, makes any warranty, express or implied, or assumes any legal liability or responsibility for the accuracy, completeness, or usefulness of any information, apparatus, product, or process disclosed, or represents that its use would not infringe privately owned rights. Reference herein to any specific commercial product, process, or service by trade name, trademark, manufacturer, or otherwise does not necessarily constitute or imply its endorsement, recommendation, or favoring by the United States Government or any agency thereof. The views and opinions of authors expressed herein do not necessarily state or reflect those of the United States Government or any agency thereof. 


\section{DISCLAIMER}

Portions of this document may be illegible in electronic image products. Images are produced from the best available original document. 


\section{OAK RIDGE NATIONAL LABORATORY \\ OPERATED BY UNION CARBIDE CORPORATION}

NUCLEAR DIVISION

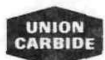

POST OFFICE BOX $X$

OAK RIDGE, TENNESSEE 37830

October 26, 1981

To: Distribution - ORNL/TM-7179 - Oak Ridge National Laboratory Shipping Containers for Radioactive Materials

Attached are revisions to ORNL/TM-7179. Please make the following changes to your copy of this report.

Section I.C

Section II.B

Section III
Add pages I.C.8a and I.C.8b

Replace pages I.C.15 and I.C.16

Replace pages II.B.3, II.B.4, II.B.5, and II.B. 6

Replace pages II.B.57 and II.B.58, and add page II.B.58a

Replace pages II.B.91, II.B.92, and II.B.93

Replace pages III.13, III.14, and III. 15

Replace Distribution Page

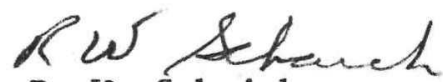

R. W. Schaich

Process Group

Operations Division

RWS : drw

Attachments
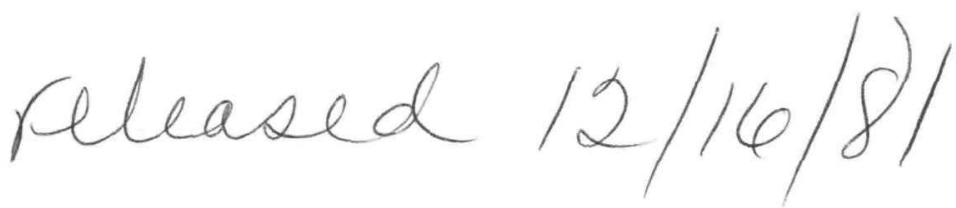


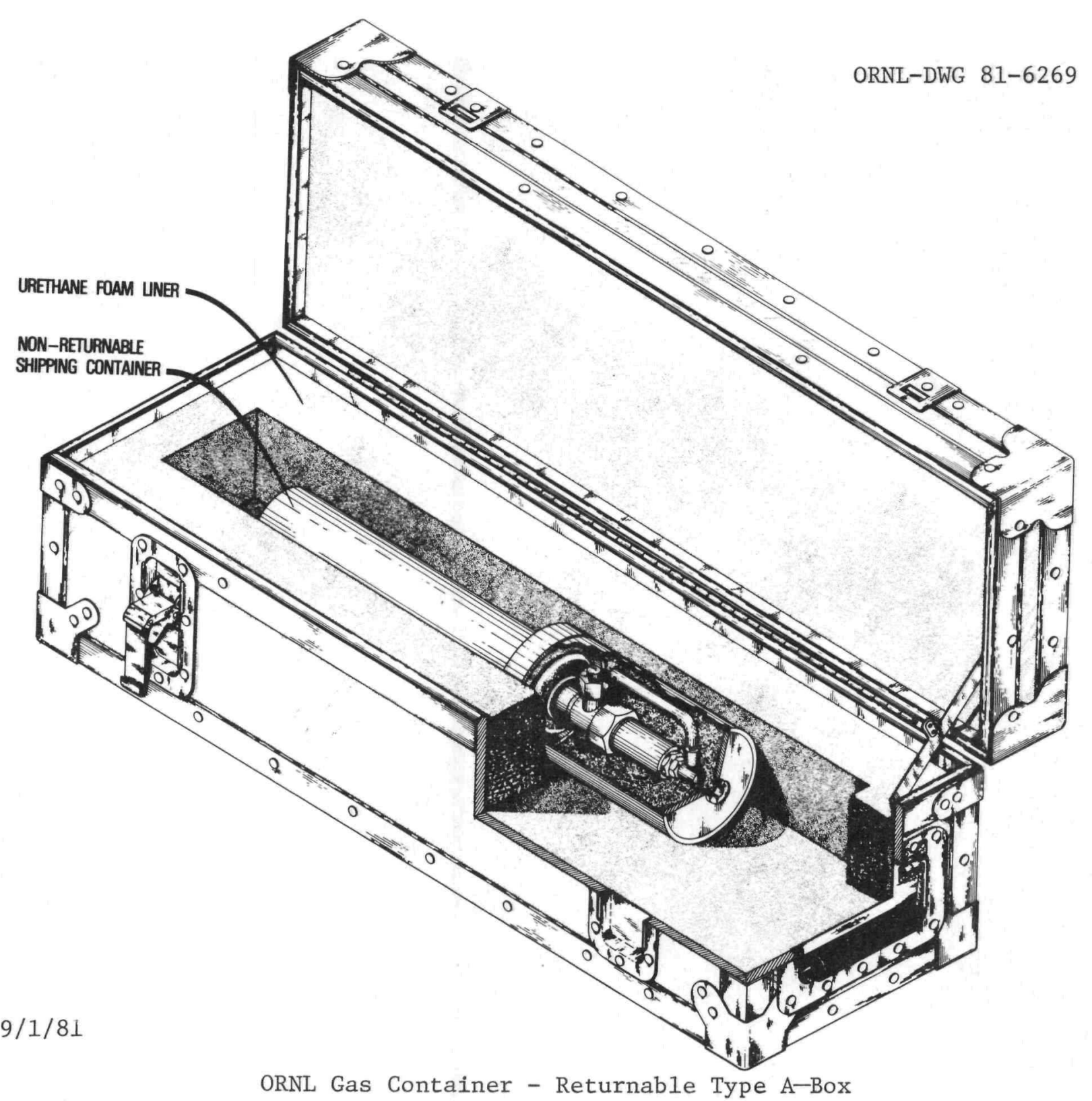


ORNL Photo 5113-81

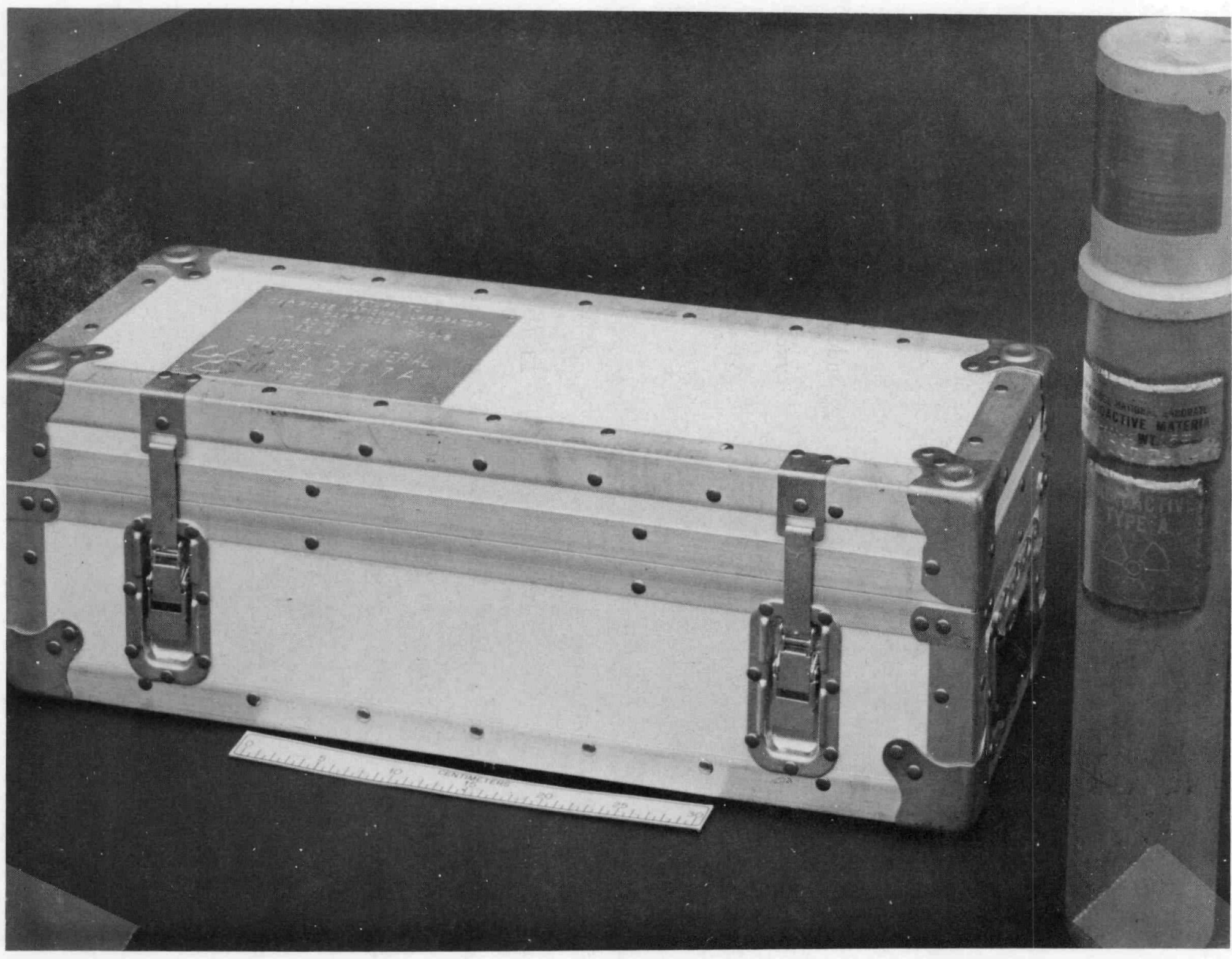


I.C. 15

DOT-IAEA TYPE A

ORNL SHIPPING CONTAINERS

C. Radioactive Gases

5. Non-Shielded - Non-Returnable (1000 cc)

Size: 2" O.D. x $251 / 2$ " Long (Cylinder)

31 1/2" x $51 / 2 "$ x $51 / 2 "$ (P1ywood box)

Inner Containment: Steel gas cylinder (1000 cc) with an "0" ring sealed valve.

Outer Containment: P1ywood box.

Weight: Cylinder -3 lbs.

Cylinder and Plywood Box - 13 1bs.

Radioactive Materials: All Type A quantities of radioactive gases not requiring lead shielding to meet DOT regulations on radiation readings. All gas pressures are less than atmospheric. 


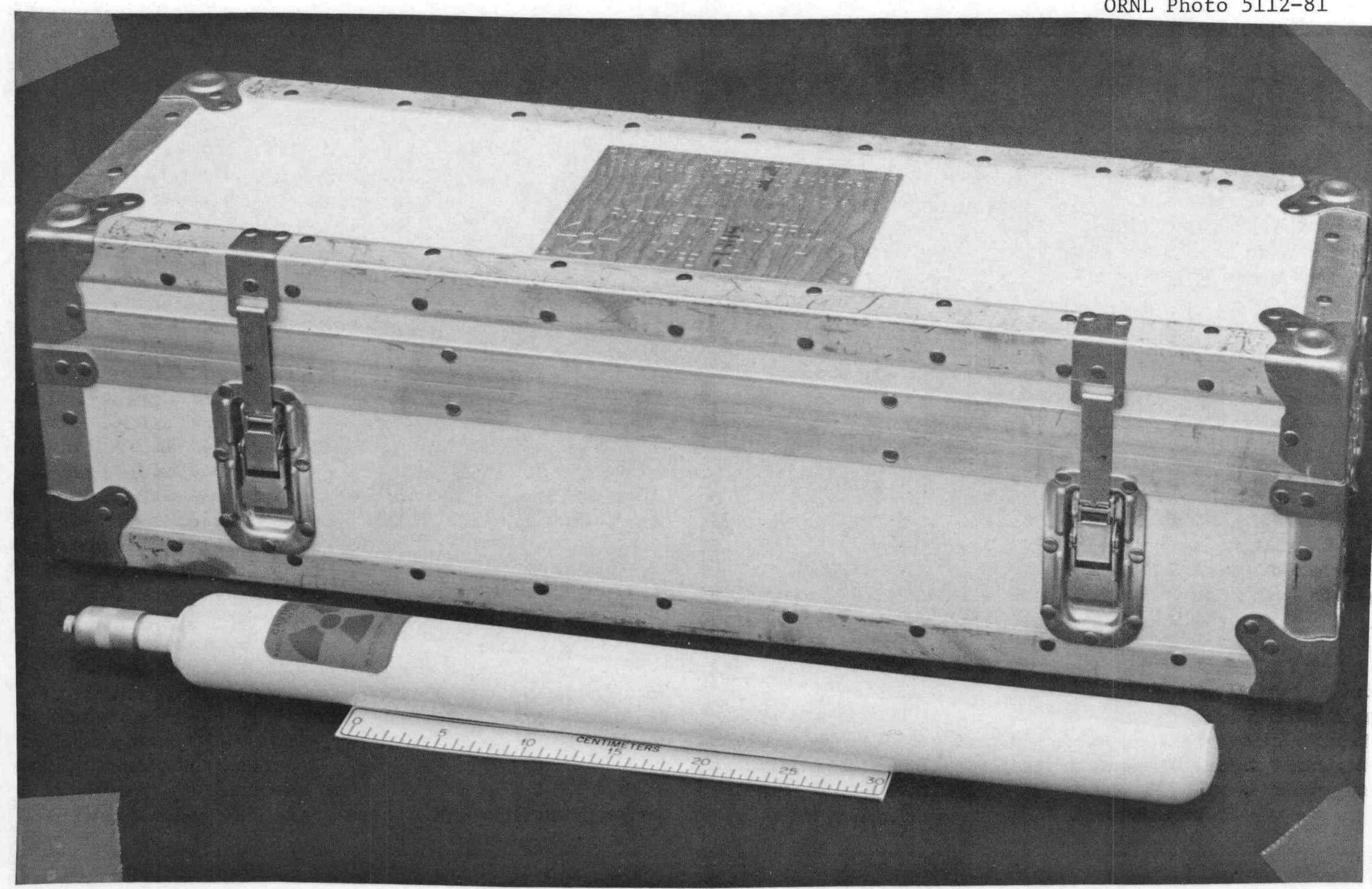

DOT Type A Shipping Package for Non-Returnable Tritium Gas Cylinder 
Table 1. (Continued)

\begin{tabular}{|c|c|c|c|c|c|c|c|c|c|c|c|c|c|c|c|c|c|}
\hline \multirow{2}{*}{ Element ${ }^{1}$} & \multirow{2}{*}{ Radionuclide ${ }^{3}$} & \multicolumn{7}{|c|}{ Transport Group } & \multirow{2}{*}{ Element ${ }^{1}$} & \multirow{2}{*}{ Radionuclide ${ }^{3}$} & \multicolumn{7}{|c|}{ Transport Group } \\
\hline & & I & II & III & IV & $\mathrm{V}$ & VI & VII & & & I & II & III & IV & $\mathrm{v}$ & VI & VII \\
\hline \multirow[t]{8}{*}{ Europium $(63) \ldots$} & $\mathrm{Eu}-147$. & $\ldots$ & $\cdots$ & $\mathrm{x}$ & $\ldots$ & $\ldots$ & $\ldots$ & $\ldots$ & \multirow[t]{3}{*}{ Iridium $(77) \ldots \ldots$} & Ir $-190 \ldots \ldots \ldots$ & $\ldots$ & $\ldots$ & $\ldots$ & $\mathrm{x}$ & $\ldots$ & $\ldots$ & \\
\hline & $\mathrm{Eu}-148 \ldots \ldots \ldots \ldots$ & $\ldots$ & $\ldots$ & $\mathrm{x}$ & ... & $\ldots$ & $\ldots$ & $\ldots$ & & Ir-192....... & $\ldots$ & $\ldots$ & $\mathrm{x}$ & $\ldots$ & $\ldots$ & $\cdots$ & \\
\hline & Eu-149......... & $\ldots$ & $\ldots$ & $\mathrm{X}$ & $\ldots$ & $\ldots$ & $\ldots$ & $\ldots$ & & Ir $-194 \ldots \ldots \ldots$ & $\ldots$ & $\ldots$ & $\ldots$ & $\mathrm{x}$ & $\ldots$ & $\ldots$ & \\
\hline & $\mathrm{Eu}-150 \ldots \ldots \ldots \ldots$ & $\ldots$ & $\ldots$ & $\mathrm{x}$ & $\ldots$ & $\ldots$ & $\ldots$ & $\ldots$ & \multirow[t]{2}{*}{ Iron $(26) \ldots \ldots \ldots$} & $\mathrm{Fe}-55 \ldots \ldots \ldots$ & $\ldots$ & $\ldots$ & $\ldots$ & $\mathrm{X}$ & $\ldots$ & $\ldots$ & \\
\hline & Eu-152m........ & ... & $\cdots$ & $\ldots$ & $\mathrm{X}$ & $\ldots$ & $\ldots$ & $\ldots$ & & $\mathrm{Fe}-59 \ldots \ldots \ldots$. & $\ldots$ & $\ldots$ & $\ldots$ & $\mathrm{x}$ & $\ldots$ & $\ldots$ & \\
\hline & $\mathrm{Eu}-152 \ldots$ & $\ldots$ & $\cdots$ & $\mathrm{x}$ & $\ldots$ & $\ldots$ & $\ldots$ & $\ldots$ & \multirow{3}{*}{ Krypton (36)..... } & $\mathrm{Kr}-85 \mathrm{~m} . \ldots \ldots \ldots$ & $\ldots$ & $\ldots$ & $\mathrm{x}$ & $\ldots$ & $\ldots$ & $\ldots$ & \\
\hline & $\mathrm{Eu}-154 \ldots \ldots \ldots$ & $\ldots$ & $\mathrm{x}$ & $\ldots$ & $\ldots$ & $\ldots$ & $\ldots$ & $\ldots$ & & $\mathrm{Kr}-85 \mathrm{~m}$ & & & & & & & \\
\hline & $\mathrm{Eu}-155 \ldots$ & $\ldots$ & $\ldots$ & $\ldots$ & $\mathrm{X}$ & $\ldots$ & $\ldots$ & $\ldots$ & & (un & & & $\cdots$ & & $\mathrm{x}$ & ... & \\
\hline Fluorine (9).... & $F-18 \ldots \ldots \ldots \ldots$ & $\ldots$ & $\cdots$ & $\ldots$ & $\mathrm{X}$ & $\ldots$ & $\ldots$ & $\ldots$ & & $\mathrm{Kr}-85 \ldots$ & $\ldots$ & $\ldots$ & $\mathrm{X}$ & $\ldots$ & ... & $\ldots$ & \\
\hline \multirow[t]{3}{*}{ Gadolinium (64).. } & $\mathrm{Gd}-151 \ldots$ & $\ldots$ & $\ldots$ & $\mathrm{x}$ & $\ldots$ & $\ldots$ & $\ldots$ & $\ldots$ & & & & & & & & & \\
\hline & $\mathrm{Gd}-153$. & $\ldots$ & $\ldots$ & $\ldots$ & $\mathrm{X}$ & $\ldots$ & $\ldots$ & $\ldots$ & & (uncompressed) $^{2}$ & $\ldots$ & $\cdots$ & $\cdots$ & & & $\mathrm{x}$ & \\
\hline & $\mathrm{Gd}-159 \ldots \ldots \ldots$ & $\ldots$ & $\ldots$ & $\ldots$ & $\mathrm{X}$ & $\ldots$ & $\ldots$ & $\ldots$ & & $\mathrm{Kr}-87 \ldots \ldots \ldots$ & $\ldots$ & $\mathrm{x}$ & $\ldots$ & $\ldots$ & $\ldots$ & $\ldots$ & \\
\hline \multirow[t]{2}{*}{ Gallium (31).... } & $\mathrm{Ga}-67 \ldots \ldots \ldots \ldots$ & $\ldots$ & $\ldots$ & $\mathrm{x}$ & $\ldots$ & $\ldots$ & $\ldots$ & $\ldots$ & & $\mathrm{Kr}-87$ & & & & & & & \\
\hline & $\mathrm{Ga}-72 \ldots$ & $\ldots$ & $\ldots$ & $\ldots$ & $\mathrm{x}$ & $\ldots$ & $\ldots$ & $\ldots$ & & sed $)^{2}$ & $\ldots$ & $\ldots$ & $\ldots$ & & $\mathrm{x}$ & $\ldots$ & \\
\hline \multirow{2}{*}{ Germanium (32)... } & Ge-68......... & $\ldots$ & $\ldots$ & $\mathrm{X}$ & $\ldots$ & $\ldots$ & $\ldots$ & $\ldots$ & \multirow{2}{*}{$\begin{array}{l}\text { Lanthanum }(57) \ldots \ldots \\
\text { Lead }(82) \ldots \ldots \ldots\end{array}$} & $140 \ldots \ldots \ldots$ & $\ldots$ & $\ldots$ & $\ldots$ & $\mathrm{x}$ & $\ldots$ & $\ldots$ & \\
\hline & $\ldots \ldots$ & $\ldots$ & $\cdots$ & $\ldots$ & $\mathrm{x}$ & $\cdots$ & $\cdots$ & $\ldots$ & & $\ldots$. & $\ldots$ & $\ldots$ & \multirow{2}{*}{$\cdots$} & \multicolumn{2}{|c|}{$x \quad \ldots$} & \multirow{2}{*}{$\cdots$} & $\cdots$ \\
\hline \multirow[t]{6}{*}{ Gold (79)....... } & $\mathrm{Au}-193 . \ldots \ldots \ldots$ & $\ldots$ & .. & $\mathrm{X}$ & $\ldots$ & $\ldots$ & $\ldots$ & $\ldots$ & \multirow{4}{*}{ Lutetium (71).... } & $\mathrm{Pb}-210 \ldots \ldots \ldots$ & $\ldots$ & $\mathrm{X}$ & & $\ldots$ & $\ldots$ & & $\cdots$ \\
\hline & $\mathrm{Au}-194 \ldots \ldots \ldots \ldots$ & $\ldots$ & $\cdots$ & $\mathrm{X}$ & $\ldots$ & $\ldots$ & $\ldots$ & $\ldots$ & & $\mathrm{Pb}-212 \ldots \ldots \ldots$ & $\ldots$ & $\mathrm{X}$ & $\ldots$ & $\ldots$ & $\ldots$ & $\cdots$ & \\
\hline & $\mathrm{Au}-195 \ldots \ldots \ldots$ & $\ldots$ & $\ldots$ & $\mathrm{X}$ & $\ldots$ & $\ldots$ & $\ldots$ & $\ldots$ & & $170 \ldots \ldots \ldots$ & $\ldots$ & $\ldots$ & $\mathrm{x}$ & $\ldots$ & $\ldots$ & $\ldots$ & \\
\hline & $\mathrm{Au}-196$ & $\ldots$ & $\ldots$ & $\ldots$ & $\mathrm{X}$ & $\ldots$ & $\ldots$ & $\ldots$ & & $\cdots$ & $\cdots$ & ... & $\mathrm{x}$ & $\cdots$ & $\cdots$ & ... & \\
\hline & $\mathrm{Au}-198 \ldots$. & $\ldots$ & $\cdots$ & $\ldots$ & $\mathrm{x}$ & $\ldots$ & $\ldots$ & $\cdots$ & & $172 \ldots \ldots \ldots$ & $\ldots$ & $\ldots$ & $\mathrm{x}$ & $\ldots$ & $\ldots$ & $\ldots$ & \\
\hline & $\mathrm{Au}-199 \ldots \ldots \ldots$. & $\ldots$ & $\cdots$ & $\ldots$ & $\mathrm{x}$ & $\ldots$ & $\ldots$ & $\ldots$ & & $\mathrm{Lu}-174 \ldots \ldots \ldots$ & $\ldots$ & $\mathrm{X}$ & $\ldots$ & $\ldots$ & $\cdots$ & ... & \\
\hline Hafnium (72).... & Hf-181........ & $\ldots$ & $\ldots$ & $\ldots$ & $\mathrm{x}$ & $\ldots$ & $\ldots$ & $\ldots$ & & $\mathrm{Lu}-177 \ldots \ldots \ldots$ & $\ldots$ & $\ldots$ & $\ldots$ & $\mathrm{x}$ & $\cdots$ & $\cdots$ & \\
\hline Holmium (67)..... & . $\ldots \ldots \ldots \ldots$ & $\ldots$ & $\ldots$ & $\ldots$ & $\mathrm{x}$ & $\ldots$ & $\ldots$ & $\ldots$ & Magnesium (12).... & $\mathrm{Mg}-28 \ldots \ldots \ldots \ldots$ & $\ldots$ & $\ldots$ & $\mathrm{x}$ & $\ldots$ & $\ldots$ & $\ldots$ & \\
\hline Hydrogen (1).... & ee tritium) & $\ldots$ & $\ldots$ & $\ldots$ & $\ldots$ & $\ldots$ & $\ldots$ & .. & Manganese $(25) \ldots$. & $\ldots$ & $\ldots$ & $\ldots$ & $\cdots$ & $\mathrm{X}$ & $\ldots$ & $\ldots$ & \\
\hline Indium $(49(\ldots \ldots)$ & In-113m......... & $\ldots$ & $\cdots$ & $\ldots$ & $\mathrm{X}$ & $\ldots$ & $\ldots$ & $\ldots$ & & $54 \ldots \ldots \ldots$ & $\ldots$ & $\ldots$ & $\cdots$ & $\mathrm{x}$ & $\cdots$ & $\cdots$ & \\
\hline & In-114m........ & $\ldots$ & $\ldots$ & $\mathrm{X}$ & $\ldots$ & $\ldots$ & $\ldots$ & $\ldots$ & & $M n-56 \ldots \ldots \ldots$ & $\ldots$ & $\ldots$ & $\ldots$ & $\mathrm{X}$ & $\ldots$ & $\ldots$ & \\
\hline & In-115m........ & $\ldots$ & $\ldots$ & $\ldots$ & $\mathrm{X}$ & $\ldots$ & $\ldots$ & $\ldots$ & Mercury $(80) \ldots$ & $\mathrm{Hg}-197 \mathrm{~m} . \ldots \ldots$ & $\ldots$ & $\ldots$ & $\ldots$ & $\mathrm{x}$ & $\ldots$ & $\ldots$ & \\
\hline & $\ldots \ldots \ldots$ & $\ldots$ & $\ldots$ & $\ldots$ & $\mathrm{x}$ & $\ldots$ & $\ldots$ & $\ldots$ & & $\mathrm{Hg}-197 \ldots \ldots \ldots$ & $\ldots$ & $\ldots$ & $\ldots$ & $\mathrm{x}$ & $\ldots$ & $\ldots$ & \\
\hline Iodine $(53) \ldots .$. & $I-123 \ldots \ldots \ldots \ldots$ & $\ldots$ & $\ldots$ & $\mathrm{X}$ & $\ldots$ & $\ldots$ & $\ldots$ & $\ldots$ & & $\mathrm{Hg}-203 . \ldots \ldots \ldots$ & $\ldots$ & $\ldots$ & $\ldots$ & $\mathrm{x}$ & $\ldots$ & ... & \\
\hline & $I-124 \ldots$ & $\ldots$ & $\cdots$ & $\mathrm{x}$ & $\ldots$ & $\ldots$ & $\ldots$ & $\cdots$ & Mixed Fission & & & & & & & & \\
\hline & $\mathrm{I}-125 \ldots \ldots \ldots \ldots$ & $\ldots$ & .. & $\mathrm{x}$ & $\ldots$ & $\ldots$ & $\ldots$ & $\ldots$ & Products........ & & & $\mathrm{x}$ & $\ldots$ & $\cdots$ & $\cdots$ & $\cdots$ & \\
\hline & $I-126 \ldots \ldots \ldots \ldots$ & $\ldots$ & $\ldots$ & $\mathrm{x}$ & $\ldots$ & $\ldots$ & $\ldots$ & $\ldots$ & Molybdenum (42)... & Мo-93.. & $\ldots$ & $\mathrm{x}$ & $\ldots$ & $\ldots$ & $\ldots$ & $\ldots$ & \\
\hline & $I-129 \ldots \ldots \ldots \ldots$ & $\ldots$ & $\ldots$ & $\mathrm{X}$ & $\ldots$ & $\ldots$ & $\ldots$ & $\ldots$ & & Mo-99......... & $\ldots$ & $\ldots$ & $\ldots$ & $\mathrm{x}$ & $\ldots$ & $\ldots$ & \\
\hline & $I-130 \ldots$ & $\ldots$ & $\cdots$ & $\mathrm{x}$ & $\ldots$ & $\ldots$ & $\ldots$ & $\ldots$ & Neodymium $(60) \ldots$ & Nd-147... & $\ldots$ & $\ldots$ & $\ldots$ & $\mathrm{x}$ & $\ldots$ & $\ldots$ & \\
\hline & $\mathrm{I}-131 \ldots$ & $\ldots$ & $\cdots$ & $\mathrm{X}$ & $\ldots$ & $\ldots$ & $\ldots$ & & & Nd-149... & $\ldots$ & $\ldots$ & $\ldots$ & $\mathrm{x}$ & $\ldots$ & $\ldots$ & \\
\hline & $I-132 \ldots \ldots \ldots \ldots$ & $\ldots$ & $\ldots$ & $\ldots$ & $\mathrm{X}$ & $\ldots$ & $\ldots$ & $\ldots$ & Neptunium (93).... & $\mathrm{Np}-237 \ldots$ & $\mathrm{x}$ & $\ldots$ & $\cdots$ & $\cdots$ & $\cdots$ & $\cdots$ & \\
\hline & $I-133 \ldots \ldots \ldots \ldots$ & $\ldots$ & $\ldots$ & $\mathrm{x}$ & $\ldots$ & $\cdots$ & $\ldots$ & $\cdots$ & & Np-239......... & $\mathrm{X}$ & ... & $\ldots$ & $\ldots$ & $\cdots$ & $\cdots$ & . \\
\hline & $I-134 \ldots \ldots \ldots \ldots$ & $\cdots$ & $\cdots$ & $\cdots$ & $\mathrm{X}$ & $\cdots$ & $\cdots$ & $\cdots$ & & & & & & & & & \\
\hline & & $\cdots$ & & $\cdots$ & $\mathrm{X}$ & $\cdots$ & $\cdots$ & & & & & & & & & & \\
\hline
\end{tabular}


Table 1. (Continued)

\begin{tabular}{|c|c|c|c|c|c|c|c|c|c|c|c|c|c|c|c|c|c|}
\hline \multirow{2}{*}{ Element ${ }^{1}$} & \multirow{2}{*}{ Radionuclide ${ }^{3}$} & \multicolumn{7}{|c|}{ Transport Group } & \multirow{2}{*}{ Element ${ }^{1}$} & \multirow{2}{*}{ Radionuclide ${ }^{3}$} & \multicolumn{7}{|c|}{ Transport Group } \\
\hline & & I & II & III & IV & V & VI & VII & & & I & II & III & IV & v & VI & VII \\
\hline \multirow[t]{5}{*}{ Nickel (28)...... } & $\mathrm{Ni}-56$. & $\cdots$ & $\ldots$ & $\mathrm{X}$ & $\cdots$ & $\cdots$ & $\cdots$ & $\cdots$ & \multirow{3}{*}{ Protactinium (91). } & $\mathrm{Pa}-230 \ldots \ldots \ldots$ & $\mathrm{X}$ & $\cdots$ & $\cdots$ & $\cdots$ & $\cdots$ & $\cdots$ & \\
\hline & . & $\cdots$ & $\cdots$ & $\mathrm{x}$ & $\cdots$ & $\cdots$ & $\cdots$ & $\cdots$ & & $\mathrm{Pa}-231 \ldots \ldots \ldots$ & $\mathrm{X}$ & $\because$ & $\cdots$ & $\cdots$ & $\cdots$ & $\cdots$ & * \\
\hline & $\mathrm{Ni}-59$. & $\cdots$ & $\cdots$ & $\cdots$ & $\mathrm{X}$ & $\ldots$ & $\cdots$ & $\cdots$ & & $\mathrm{Pa}-233 . \ldots \ldots \ldots$ & $\ldots$ & $\mathrm{X}$ & $\cdots$ & $\cdots$ & $\cdots$ & $\cdots$ & \\
\hline & $i-63$. & $\cdots$ & $\cdots$ & $\cdots$ & $\mathrm{x}$ & $\ldots$ & $\cdots$ & $\cdots$ & \multirow[t]{2}{*}{ Radium $(88) \ldots \ldots$} & $\mathrm{Ra}-223 \ldots \ldots \ldots$ & ... & $\mathrm{x}$ & $\ldots$ & $\cdots$ & $\cdots$ & $\cdots$ & \\
\hline & $\mathrm{Ni}-65$ & $\cdots$ & $\cdots$ & $\cdots$ & $\mathrm{x}$ & $\cdots$ & $\cdots$ & $\ldots$ & & $\mathrm{Ra}-224 \ldots \ldots \ldots$ & $\cdots$ & $\mathrm{x}$ & $\cdots$ & $\cdots$ & $\cdots$ & $\cdots$ & \\
\hline \multirow[t]{4}{*}{ Niobium (41).... } & $\mathrm{Nb}-91 .$. & $\ldots$ & $\cdots$ & $\mathrm{X}$ & $\cdots$ & $\ldots$ & $\cdots$ & $\cdots$ & \multirow{4}{*}{ Radon $(86) \ldots \ldots \ldots$} & $\mathrm{Ra}-226 \ldots$ & $\mathrm{X}$ & $\cdots$ & $\cdots$ & $\cdots$ & $\cdots$ & $\cdots$ & $\cdots$ \\
\hline & $\mathrm{Nb}-93 \mathrm{~m}$. & $\cdots$ & $\cdots$ & $\cdots$ & $\mathrm{X}$ & $\cdots$ & $\cdots$ & $\cdots$ & & $\mathrm{Ra}-228 \ldots \ldots \ldots$ & $\mathrm{X}$ & $\cdots$ & $\cdots$ & $\cdots$ & $\cdots$ & $\cdots$ & $\cdots$ \\
\hline & $\mathrm{Nb}-95 \ldots$ & $\cdots$ & $\cdots$ & $\cdots$ & $\mathrm{x}$ & $\cdots$ & $\cdots$ & $\cdots$ & & $\mathrm{Rn}-220 \ldots \ldots \ldots$ & $\cdots$ & $\cdots$ & $\cdots$ & $\mathrm{X}$ & $\cdots$ & $\cdots$ & $\cdots$ \\
\hline & $\mathrm{Nb}-97 .$. & $\cdots$ & $\cdots$ & $\cdots$ & $\mathrm{X}$ & $\cdots$ & $\cdots$ & $\cdots$ & & & $\cdots$ & $\mathrm{x}$ & $\cdots$ & $\because$ & $\cdots$ & $\cdots$ & \\
\hline \multirow[t]{4}{*}{ Osmium $(76) \ldots \ldots$} & $\cdots \cdots \cdots$ & $\cdots$ & $\cdots$ & $\cdots$ & $\mathrm{X}$ & $\cdots$ & $\cdots$ & $\cdots$ & \multirow[t]{5}{*}{ Rhenium (75) $\ldots \ldots$. } & $\cdots \cdots$ & $\cdots$ & $\cdots$ & $\cdots$ & $\begin{array}{l}x \\
x\end{array}$ & $\cdots$ & $\cdots$ & \\
\hline & $\ldots \ldots \ldots$ & $\cdots$ & $\cdots$ & $\cdots$ & $\mathrm{X}$ & $\cdots$ & $\cdots$ & $\cdots$ & & $\cdots \cdots$ & $\cdots$ & $\cdots$ & $\cdots$ & $\begin{array}{l}x \\
y\end{array}$ & $\cdots$ & $\cdots$ & $\cdot$ \\
\hline & $0 s-19$ & $\cdots$ & $\cdots$ & $\cdots$ & $x$ & $\ldots$ & $\cdots$ & $\cdots$ & & $\cdots$ & $\cdots$ & $\cdots$ & $\cdots$ & $\mathrm{x}$ & $\cdots$ & $\cdots$ & $\cdots$ \\
\hline & 0s-193. . & $\cdots$ & $\cdots$ & $\cdots$ & $\mathrm{X}$ & $\cdots$ & $\cdots$ & $\cdots$ & & $\mathrm{Re}-188$ & $\cdots$ & $\cdots$ & $\cdots$ & $\mathrm{X}$ & $\cdots$ & $\cdots$ & $\cdots$ \\
\hline \multirow[t]{2}{*}{ Palladium (46)... } & $\mathrm{Pd}-103 \ldots$ & $\cdots$ & $\cdots$ & $\cdots$ & $\mathrm{x}$ & $\cdots$ & $\cdots$ & $\cdots$ & & Re Natural.. & $\cdots$ & $\cdots$ & $\cdots$ & $\mathrm{X}$ & $\cdots$ & $\cdots$ & $\cdots$ \\
\hline & $\mathrm{Pd}-109 . . . \ldots \ldots$ & $\cdots$ & $\cdots$ & $\cdots$ & $\mathrm{x}$ & $\cdots$ & $\cdots$ & $\cdots$ & \multirow{4}{*}{ Rhodium (45)..... } & $\mathrm{Rh}-99 \ldots \ldots \ldots$ & $\cdots$ & $\cdots$ & $\mathrm{X}$ & $\cdots$ & $\cdots$ & $\cdots$ & $\cdots$ \\
\hline \multirow{2}{*}{ Phosphorus (15).. } & $P-32 \ldots \ldots \ldots \ldots$ & $\cdots$ & $\cdots$ & $\cdots$ & $\mathrm{X}$ & $\cdots$ & $\cdots$ & $\cdots$ & & $2 \ldots \ldots \ldots$ & $\cdots$ & $\cdots$ & $\mathrm{X}$ & $\cdots$ & $\cdots$ & $\cdots$ & \\
\hline & $P-33$ & $\cdots$ & $\cdots$ & $\cdots$ & $\mathrm{X}$ & $\cdots$ & $\cdots$ & $\cdots$ & & $\cdots \cdots$ & $\cdots$ & $\cdots$ & $\cdots$ & $\mathrm{X}$ & $\cdots$ & $\cdots$ & \\
\hline \multirow[t]{6}{*}{ Platinum (78).... } & $\cdots \cdots$ & $\cdots$ & $\cdots$ & $\cdots$ & $\mathrm{X}$ & $\cdots$ & $\cdots$ & $\cdots$ & & $\ldots \ldots$ & $\cdots$ & $\cdots$ & $\cdots$ & $\mathrm{X}$ & $\cdots$ & $\cdots$ & $\cdots$ \\
\hline & Pt -193 & $\cdots$ & $\cdots$ & $\cdots$ & $\mathrm{X}$ & $\cdots$ & $\cdots$ & $\cdots$ & \multirow{4}{*}{ Rubidium (37).... } & $\mathrm{Rb}-84 .$. & $\cdots$ & $\cdots$ & $\mathrm{X}$ & $\cdots$ & $\cdots$ & $\cdots$ & $\cdots$ \\
\hline & $\cdots \ldots \ldots$ & $\cdots$ & $\cdots$ & $\cdots$ & $\mathrm{x}$ & $\cdots$ & $\cdots$ & $\cdots$ & & $\cdots \cdots$ & $\cdots$ & $\cdots$ & $\cdots$ & $\mathrm{X}$ & $\cdots$ & $\cdots$ & \\
\hline & $\cdots \cdots \cdots$ & $\cdots$ & $\cdots$ & $\cdots$ & $\mathrm{X}$ & $\cdots$ & $\cdots$ & $\cdots$ & & $\cdots \cdots$ & $\cdots$ & $\cdots$ & $\cdots$ & $\mathrm{x}$ & $\cdots$ & $\cdots$ & \\
\hline & $\cdots \cdots$ & $\cdots$ & $\cdots$ & $\cdots$ & $\mathrm{X}$ & $\cdots$ & $\cdots$ & $\cdots$ & & al.... & $\cdots$ & $\cdots$ & $\cdots$ & $\mathrm{x}$ & $\cdots$ & $\cdots$ & \\
\hline & $\mathrm{Pt}-197 \ldots \ldots \ldots \ldots$ & $\cdots$ & $\cdots$ & $\cdots$ & $\mathrm{X}$ & $\cdots$ & $\cdots$ & $\cdots$ & \multirow[t]{4}{*}{ Ruthenium (44).... } & $\mathrm{Ru}-97 \ldots \ldots \ldots$ & $\cdots$ & $\cdots$ & $\cdots$ & $\mathrm{X}$ & $\cdots$ & $\cdots$ & \\
\hline \multirow[t]{5}{*}{ Plutonium $(94) \ldots$} & ${ }^{4} \ldots \ldots \ldots$ & $\mathrm{X}$ & $\cdots$ & $\cdots$ & $\cdots$ & $\cdots$ & $\cdots$ & $\cdots$ & & $\mathrm{Ru}-103 . \ldots \ldots \ldots$ & $\cdots$ & $\cdots$ & $\cdots$ & $\mathrm{X}$ & $\cdots$ & $\cdots$ & $\cdots$ \\
\hline & $\mathrm{Pu}-239^{4}$. & $\mathrm{X}$ & $\cdots$ & $\cdots$ & $\cdots$ & $\cdots$ & $\cdots$ & $\cdots$ & & $\cdots$ & $\cdots$ & $\cdots$ & $\ddot{y}$ & $\mathrm{X}$ & $\cdots$ & $\cdots$ & $\cdots$ \\
\hline & $\mathrm{Pu}-240 \ldots . . . \ldots$ & $\mathrm{X}$ & $\cdots$ & $\cdots$ & $\cdots$ & $\cdots$ & $\cdots$ & $\cdots$ & & $\mathrm{Ru}-106 \ldots \ldots \ldots$ & $\cdots$ & $\cdots$ & $\mathrm{X}$ & $\cdots$ & $\cdots$ & $\cdots$ & $\cdots$ \\
\hline & ${ }^{4} \ldots \ldots \ldots$ & $\mathrm{x}$ & $\cdots$ & & $\cdots$ & $\cdots$ & $\cdots$ & $\cdots$ & Samarium $(62) \ldots \ldots$ & $\mathrm{Sm}-145 \ldots \ldots \ldots$ & $\cdots$ & $\cdots$ & $\begin{array}{c}x \\
y\end{array}$ & $\cdots$ & $\cdots$ & $\cdots$ & \\
\hline & & $\mathrm{x}$ & $\cdots$ & $\cdots$ & $\cdots$ & $\cdots$ & $\cdots$ & $\cdots$ & & n....... & $\cdots$ & $\cdots$ & $\mathrm{X}$ & $\ddot{v}$ & $\cdots$ & $\cdots$ & \\
\hline Im $(84) \ldots$ & Po-210 & $\mathrm{x}$ & $\cdots$ & $\cdots$ & $\ddot{v}$ & $\cdots$ & $\cdots$ & $\cdots$ & & $\cdots \cdots$ & $\cdots$ & $\cdots$ & $\cdots$ & $\mathrm{X}$ & $\cdots$ & $\cdots$ & \\
\hline Potassium (19)... & $\mathrm{K}-42$ & $\cdots$ & $\cdots$ & $\cdots$ & $\mathrm{X}$ & $\cdots$ & $\cdots$ & $\cdots$ & & $\mathrm{Sm}-1$ & $\cdots$ & $\cdots$ & 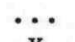 & $\mathrm{X}$ & $\cdots$ & $\cdots$ & $\cdots$ \\
\hline & $\mathrm{K}-43 \ldots$ & $\cdots$ & $\cdots$ & $\mathrm{x}$ & $\cdots$ & $\cdots$ & $\cdots$ & $\cdots$ & Scandium (21).... & $\mathrm{Sc}-44 \mathrm{~m}$. & $\cdots$ & $\cdots$ & $\mathrm{X}$ & $\cdots$ & $\cdots$ & $\cdots$ & $\cdots$ \\
\hline Praseodymium (59) & $\operatorname{Pr}-142 \ldots$ & $\cdots$ & $\cdots$ & $\cdots$ & $\mathrm{X}$ & $\cdots$ & $\cdots$ & $\cdots$ & & $\mathrm{Sc}-46 .$. & $\cdots$ & $\cdots$ & X & $\cdots$ & $\cdots$ & $\cdots$ & $\cdots$ \\
\hline & $\mathrm{Pr}-14$ & $\cdots$ & $\cdots$ & $\ddot{y}$ & $\mathrm{X}$ & $\cdots$ & $\cdots$ & $\cdots$ & & $\mathrm{Sc}-47 \ldots$ & & $\cdots$ & $\cdots$ & $\underset{\mathrm{X}}{\mathrm{X}}$ & $\cdots$ & $\cdot$ & \\
\hline Promethium (61).. & $\begin{array}{l}\mathrm{Pm}-143 \ldots \\
\mathrm{Pm}-144 \ldots\end{array}$ & $\cdots$ & $\cdots$ & $\begin{array}{l}\mathrm{X} \\
\mathrm{X}\end{array}$ & $\cdots$ & $\begin{array}{l}\cdots \\
\cdots\end{array}$ & $\begin{array}{l}\cdots \\
\ldots\end{array}$ & $\begin{array}{l}\cdots \\
\cdots\end{array}$ & & $\begin{array}{l}\mathrm{Sc}-48 \ldots \ldots \ldots \ldots \\
\mathrm{Se}-75 \ldots \ldots \ldots \ldots\end{array}$ & $\cdots$ & $\cdots$ & $\because$ & $\begin{array}{l}X \\
X\end{array}$ & $\cdots$ & $\cdots$ & \\
\hline & $\begin{array}{l}\mathrm{Pm}-1 \\
\mathrm{Pm}-1\end{array}$ & $\ldots$ & $\ddot{x}$ & $\begin{array}{l}\mathrm{X} \\
\ldots\end{array}$ & $\cdots$ & 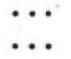 & $\cdots$ & $\begin{array}{l}\cdots \\
\cdots\end{array}$ & Selenium (34).... & $\begin{array}{l}\mathrm{Se}-75 \\
\mathrm{Si}-31\end{array}$ & $\cdots$ & $\cdots$ & $\cdots$ & $\begin{array}{l}\hat{A} \\
\mathrm{x}\end{array}$ & $\ddot{m}$ & $\cdots$ & 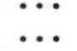 \\
\hline & $P m-146 \ldots \ldots \ldots \ldots$ & $\ldots$ & $\mathrm{x}$ & $\cdots$ & $\cdots$ & $\cdots$ & $\ldots$ & $\cdots$ & $\begin{array}{l}\text { Silicon (14) } \\
\text { Silver (47). }\end{array}$ & $\mathrm{Ag}-1 \mathrm{C}$ & $\ldots$ & $\ldots$ & $\ldots$ & $\mathrm{x}$ & $\ldots$ & & $\cdots$ \\
\hline & $\mathrm{Pm}-147 \ldots . . . \ldots$ & $\ldots$ & $\cdots$ & $\ldots$ & $\mathrm{x}$ & $\cdots$ & $\cdots$ & $\ldots$ & & $\mathrm{Ag}-110 \mathrm{~m} . . . .$. & $\cdots$ & $\cdots$ & $\mathrm{X}$ & $\cdots$ & $\cdots$ & $\ldots$ & $\cdots$ \\
\hline & Pm-149.......... & $\cdots$ & $\cdots$ & $\cdots$ & $\mathrm{X}$ & $\cdots$ & $\ldots$ & $\cdots$ & & $\mathrm{Ag}-111 \ldots \ldots \ldots$ & $\cdots$ & $\cdots$ & $\cdots$ & $\mathrm{X}$ & $\cdots$ & $\cdots$ & $\cdots$ \\
\hline
\end{tabular}


Table 1. (Continued)

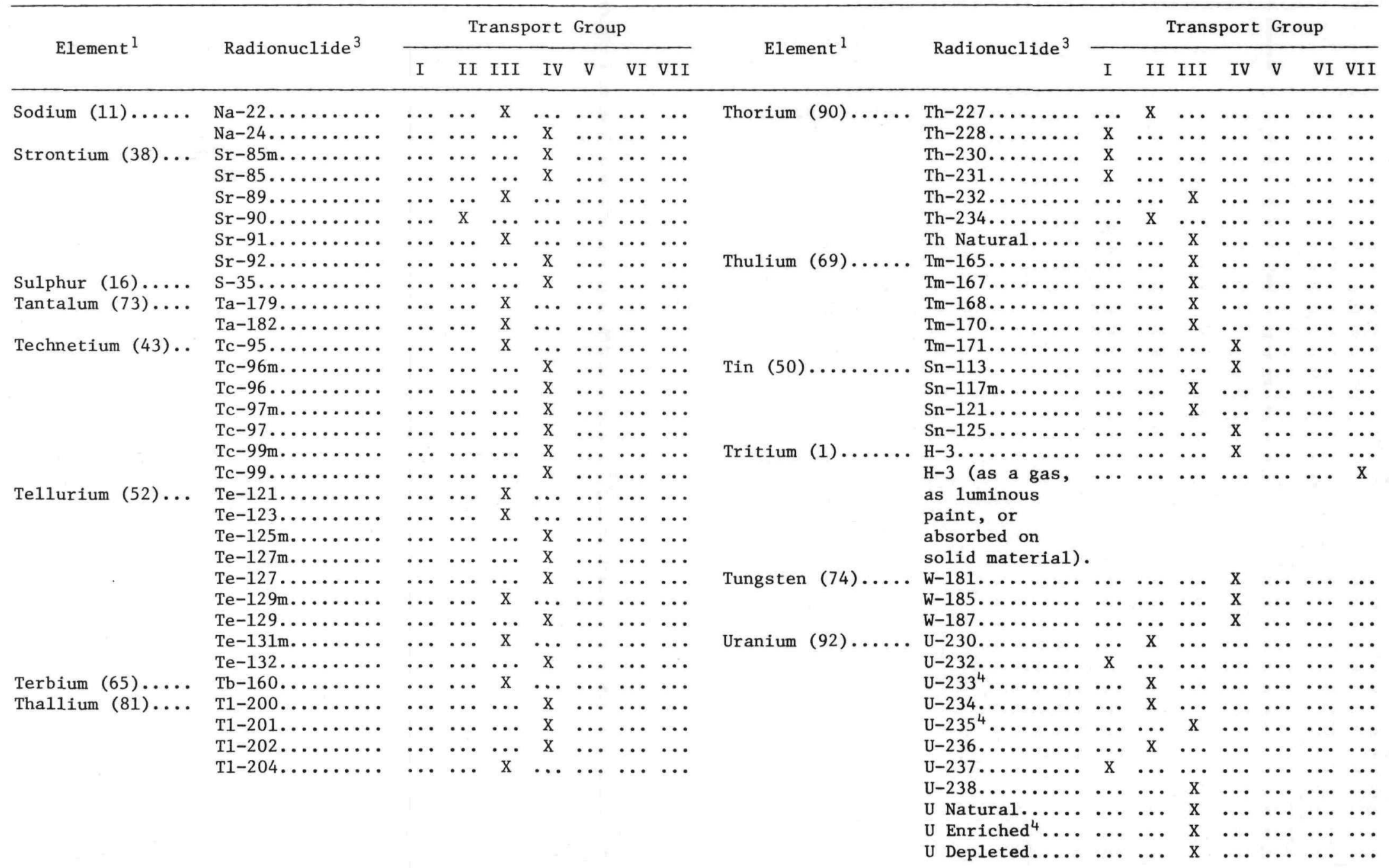


Table 1. (Continued)

\begin{tabular}{|c|c|c|c|c|c|c|c|c|c|c|c|c|c|c|c|c|c|}
\hline \multirow{2}{*}{ Element ${ }^{1}$} & \multirow{2}{*}{ Radionuclide $^{3}$} & \multicolumn{7}{|c|}{ Transport Group } & \multirow{2}{*}{ Element ${ }^{1}$} & \multirow{2}{*}{ Radionuclide ${ }^{3}$} & \multicolumn{7}{|c|}{ Transport Group } \\
\hline & & I & II & III & IV & $\mathrm{v}$ & VI & VII & & & I & II & III & IV & V & VI & VII \\
\hline \multirow[t]{2}{*}{ Vanadium $(23) \ldots$} & $v-48 \ldots \ldots \ldots \ldots$ & $\cdots$ & $\cdots$ & $\cdots$ & $\mathrm{X}$ & $\cdots$ & $\cdots$ & $\ldots$ & \multirow{7}{*}{$\begin{array}{l}\text { Ytterbium (70).... } \\
\text { Yttrium (39)...... }\end{array}$} & $\mathrm{Yb}-175 \ldots \ldots \ldots$ & $\cdots$ & $\ldots$ & $\ldots$ & $\mathrm{x}$ & $\cdots$ & $\cdots$ & $\cdots$ \\
\hline & $v-49 \ldots \ldots \ldots \ldots$ & $\cdots$ & $\ldots$ & $\mathrm{X}$ & $\ldots$ & $\cdots$ & $\cdots$ & $\cdots$ & & $Y-86 \ldots \ldots \ldots$ & $\cdots$ & $\cdots$ & $\mathrm{X}$ & $\cdots$ & $\cdots$ & $\cdots$ & $\cdots$ \\
\hline \multirow{10}{*}{ Xenon $(54) \ldots \ldots$. } & $\mathrm{Xe}-125 \ldots \ldots \ldots$ & $\cdots$ & $\ldots$ & $\mathrm{x}$ & $\cdots$ & $\cdots$ & $\ldots$ & $\ldots$ & & $\mathrm{Y}-87 \ldots \ldots \ldots \ldots$ & $\cdots$ & $\ldots$ & $\mathrm{x}$ & $\cdots$ & $\ldots$ & $\ldots$ & $\cdots$ \\
\hline & Xe-131m.......... & $\cdots$ & $\cdots$ & $\mathrm{x}$ & $\cdots$ & $\cdots$ & $\cdots$ & $\cdots$ & & $Y-88 \ldots \ldots \ldots \ldots$ & $\cdots$ & $\cdots$ & $\mathrm{X}$ & $\cdots$ & $\cdots$ & $\cdots$ & $\cdots$ \\
\hline & $\mathrm{Xe-131m}$ & & & & & & & & & $\mathrm{Y}-90 \ldots \ldots \ldots \ldots$ & $\cdots$ & $\cdots$ & $\ddot{y}$ & $\mathrm{X}$ & $\cdots$ & $\cdots$ & $\cdots$ \\
\hline & $\begin{array}{l}{\text { (uncompressed) })^{2} \text {. }} \text { Xe-133.......... }\end{array}$ & $\cdots$ & $\cdots$ & $\ddot{x}$ & $\cdots$ & $\begin{array}{l}\mathrm{X} \\
\ldots\end{array}$ & $\cdots$ & $\cdots$ & & & $\cdots$ & $\cdots$ & $\begin{array}{l}\mathrm{X} \\
\mathrm{X}\end{array}$ & $\cdots$ & $\cdots$ & $\cdots$ & $\cdots$ \\
\hline & $\begin{array}{l}\mathrm{Xe}-133 \ldots \ldots \ldots \ldots \\
\mathrm{Xe}-133\end{array}$ & $\cdots$ & $\cdots$ & $\mathrm{X}$ & $\cdots$ & $\cdots$ & $\cdots$ & $\cdots$ & & $\begin{array}{l}\mathrm{Y}-91 \ldots \ldots \ldots \ldots \ldots \\
\mathrm{Y}-92 \ldots \ldots \ldots \ldots\end{array}$ & $\ddot{\cdots}$ & $\ddot{m}$ & $\begin{array}{c}x \\
\ldots\end{array}$ & $\ddot{x}$ & $\cdots$ & $\ddot{m}$ & $\ddot{m}$ \\
\hline & (uncompressed) ${ }^{2}$. & $\cdots$ & $\cdots$ & $\cdots$ & $\cdots$ & $\cdots$ & $\mathrm{X}$ & $\cdots$ & \multirow{3}{*}{ Zinc $(30) \ldots \ldots \ldots$} & $\mathrm{Y}-93 \ldots \ldots \ldots$ & $\cdots$ & $\ldots$ & $\cdots$ & $\mathrm{x}$ & ... & $\ldots$ & $\cdots$ \\
\hline & $\mathrm{Xe}-135 \ldots \ldots \ldots$ & $\cdots$ & $\mathrm{X}$ & $\cdots$ & $\cdots$ & $\cdots$ & $\cdots$ & $\cdots$ & & $\mathrm{Zn}-65 \ldots \ldots \ldots$ & $\cdots$ & $\cdots$ & $\cdots$ & $\begin{array}{l}x \\
\mathrm{x}\end{array}$ & $\cdots$ & $\cdots$ & $\cdots$ \\
\hline & $\mathrm{Xe}-135$ & & & & & & & & & Zn-69m......... & $\cdots$ & $\cdots$ & $\cdots$ & $\mathrm{x}$ & $\cdots$ & $\cdots$ & $\cdots$ \\
\hline & $(\text { uncompressed) })^{2}$. & $\cdots$ & $\cdots$ & $\cdots$ & $\cdots$ & $\mathrm{X}$ & $\cdots$ & $\cdots$ & \multirow{3}{*}{ Zirconium $(40) \ldots$. } & $\mathrm{Zn}-69 \ldots \ldots \ldots$ & $\cdots$ & $\cdots$ & ... & $\mathrm{X}$ & $\cdots$ & $\cdots$ & $\cdots$ \\
\hline & & & & & & & & & & $\begin{array}{l}\mathrm{Zr}-88 \ldots \ldots \ldots \ldots \\
\mathrm{Zr}-93 \ldots \ldots \ldots \ldots\end{array}$ & $\cdots$ & $\cdots$ & $\mathrm{X}$ & $\ddot{x}$ & $\cdots$ & $\cdots$ & $\cdots$ \\
\hline $\begin{array}{l}{ }^{1} \text { Atomic n } \\
{ }^{2} \text { Uncompre } \\
\text { (absolu }\end{array}$ & at & & & & 14 & & & & & $\begin{array}{l}\mathrm{Zr}-95 \ldots \ldots \ldots \ldots \\
\mathrm{Zr}-97 \ldots \ldots \ldots\end{array}$ & $\begin{array}{l}\cdots \\
\cdots \\
\cdots\end{array}$ & $\begin{array}{l}\cdots \\
\cdots\end{array}$ & $\ddot{x}$ & $\ddot{x}$ & $\begin{array}{l}\cdots \\
\cdots \\
\cdots\end{array}$ & $\begin{array}{l}\cdots \\
\cdots\end{array}$ & $\begin{array}{l}\cdots \\
\cdots \\
\cdots\end{array}$ \\
\hline
\end{tabular}

${ }^{3}$ Atomic weight shown after the radionuclide symbol.

${ }^{4}$ Fissile radioactive material. 


$$
\text { I.A.1 }
$$

DOT-IAEA TYPE A

ORNL SHIPPING CONTAINERS

A. Radioactive Liquids and Solids

1. Non-Shielded - Non-Returnable

Size: $8^{\prime \prime} \times 8^{\prime \prime} \times 8^{\prime \prime}$ or $12^{\prime \prime} \times 12^{\prime \prime} \times 12^{\prime \prime}$

Inner Containment: Duraglass bottle or Special Form capsule in a schedule 40 steel pipe nipple. Glass bottle volume varies from $15 \mathrm{cc}$ to $200 \mathrm{cc}$.

Outer Containment:- DOT SPEC 2N tin can in cardboard (12B) box with protective cardboard inserts.

Weight: 3 1bs.

Radioactive Materials: All Type A quantities of radioactive liquids or solids requiring minimal shielding (liquids in Duraglass bottles only). 
ORNL Photo 4281-77

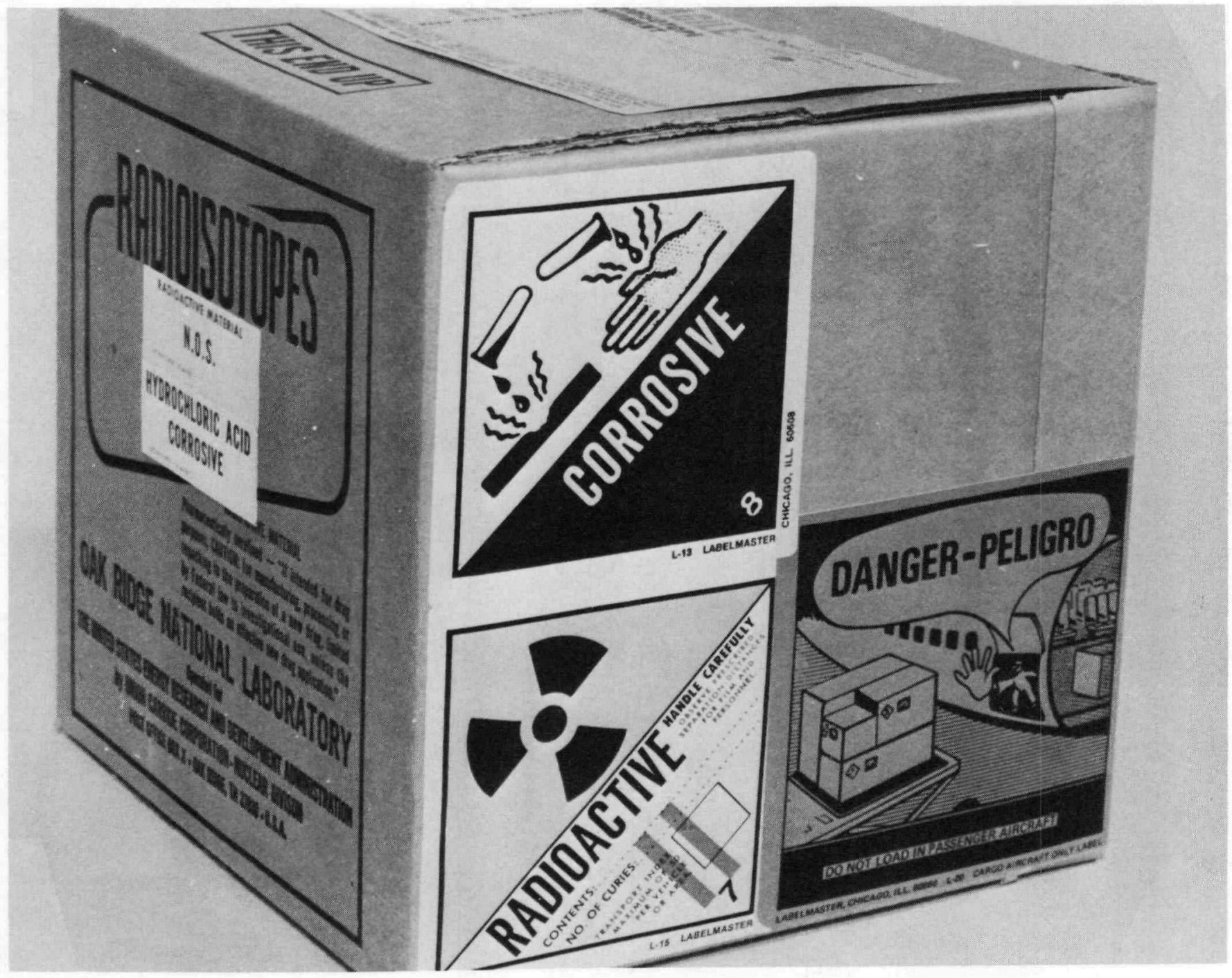

ORNL Non-Returnable Type A Package 

है

H

D

f 


\section{I.A.5}

DOT-IAEA TYPE A

ORNL SHIPPING CONTAINERS

A. Radioactive Liquids and Solids

2. Shielded - Non-Returnable

Size: $8^{\prime \prime} \times 8^{\prime \prime} \times 8^{\prime \prime}$

Innter Containment: Duraglass bottle (15-200 cc size) or Special Form capsule wrapped in absorbent material and sealed in lead shields (0.5 or 1.0 inches thick).

Outer Containment: DOT SPEC 2N tin can in cardboard (12B) box with protective cardboard inserts.

Weight: $0.5 \mathrm{in}$. lead shielding - $22 \mathrm{lbs}$.

1.0 in. lead shielding - 33 lbs.

Radioactive Materials: All Type A quantities of radioactive liquids or solids requiring lead shielding to meet DOT radiation requirements (1iquids in Duraglass bottles only).

Revised 3/1/81 
ORNL Photo 2271-78

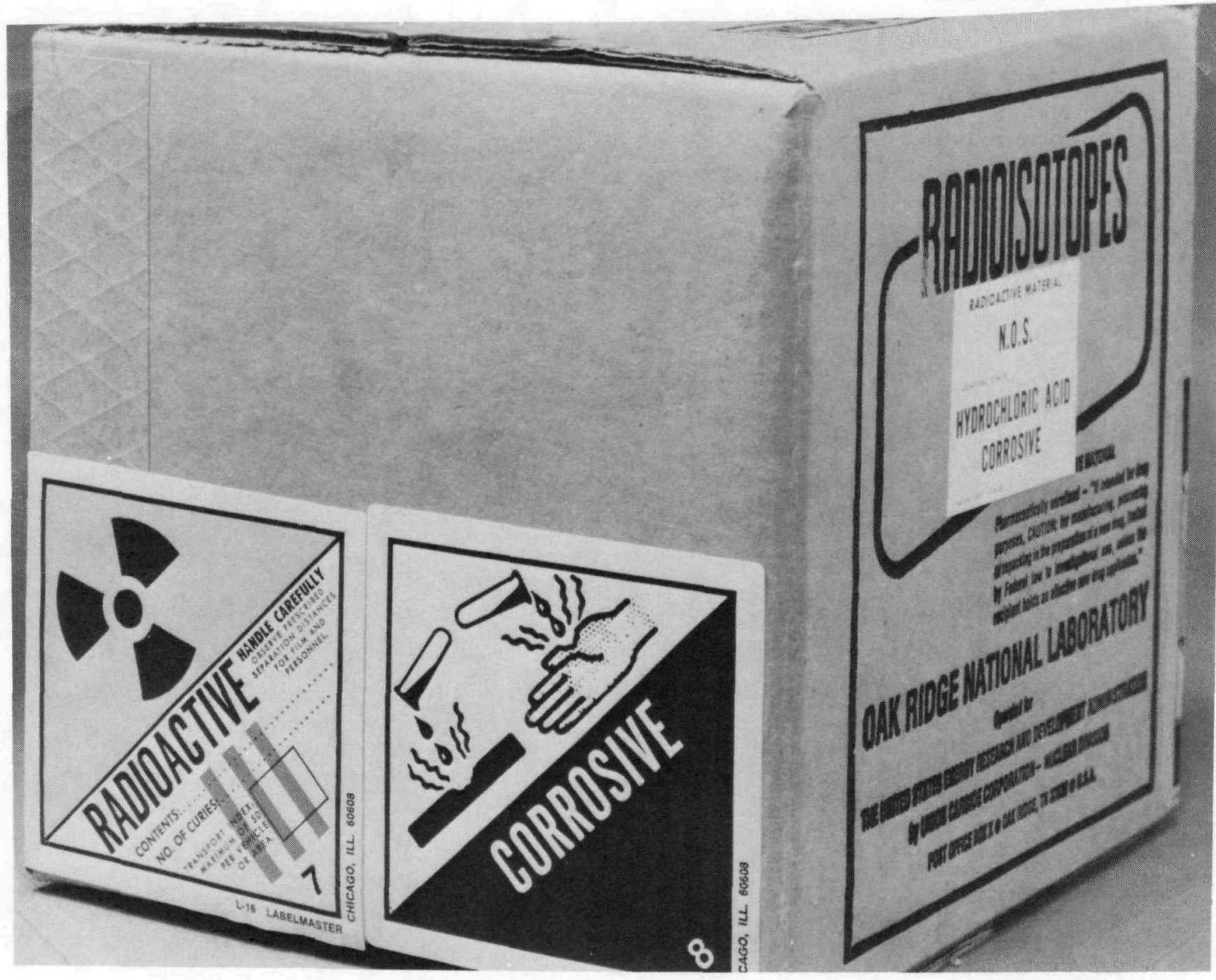

$\stackrel{+}{\dot{a}}$

ORNL Non-Returnable Type A Package

( 8 in. by 8 in. by 8 in.) 


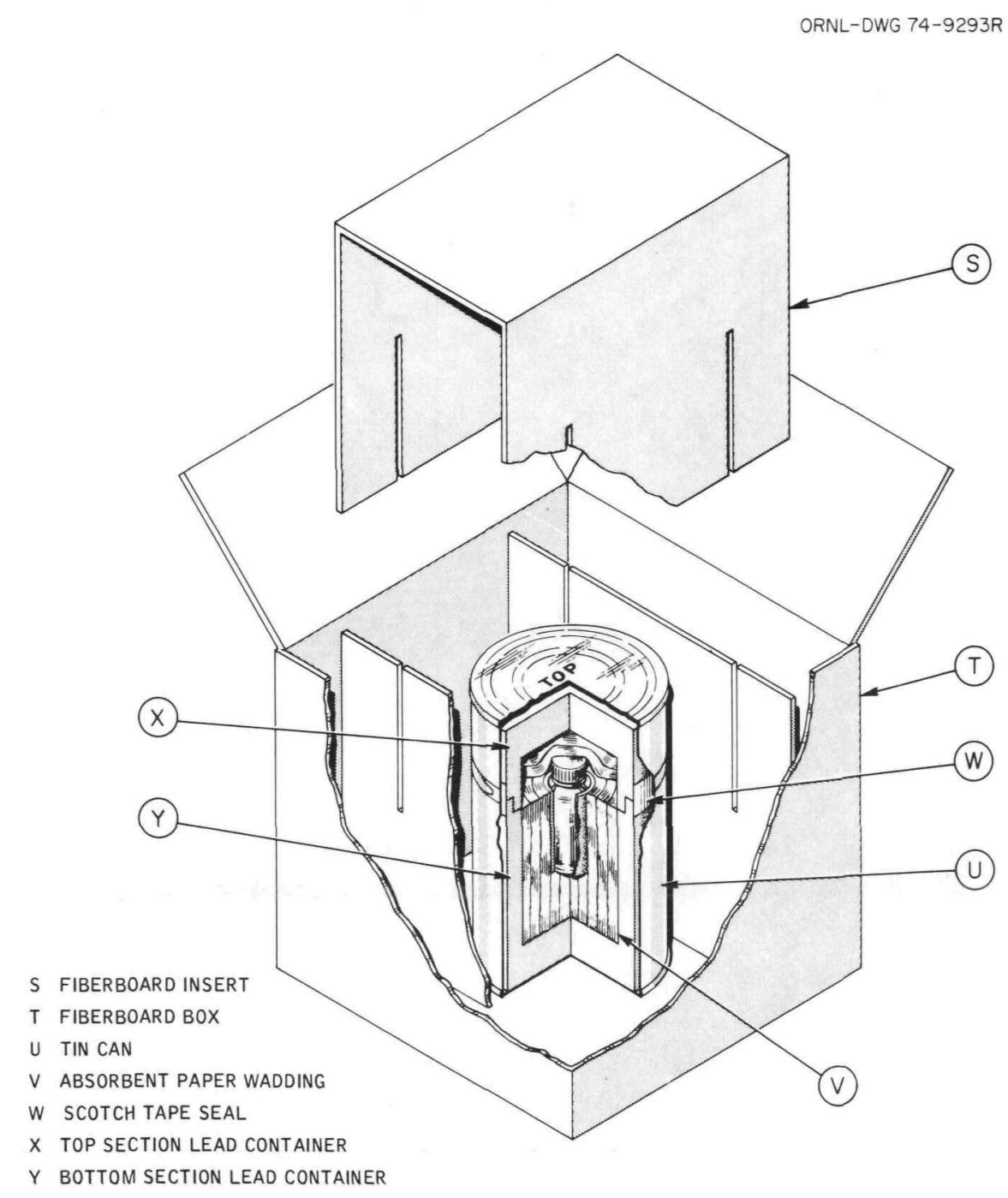

DISPOSABLE CONTAINER FOR RADIOACTIVE

LIQUID AND SOLID SHIPMENTS

Limited to DOT Type A Quantities 


\section{I.A. 8}

DOT-IAEA Type A

ORNL SHIPPING CONTAINERS

\section{A. Radioactive Liquids and Solids}

\section{Shielded - Returnable Outer Container}

Size: $15^{\prime \prime} \times 15^{\prime \prime} \times 15^{\prime \prime}$

Inner Containment: Duraglass bottle (15-50 cc size) or Special Form capsule wrapped in absorbent material and sealed in lead shields ( 0.5 to 1.2 inches thick).

Outer Containment: DOT SPEC $2 \mathrm{~N}$ tin can in cardboard (12B) box with protective cardboard inserts. Cardboard box is placed in a fiberglass aluminum reinforced case.

Weight: 0.5 in. 1ead shield - 40 lbs.

$$
\begin{aligned}
& 1.0 \mathrm{in.} \text { lead shielding - } 48 \mathrm{lbs} . \\
& 1.2 \mathrm{in.} \text { lead shielding - } 51 \mathrm{lbs} .
\end{aligned}
$$

Radioactive Materials: All Type A quantities of radioactive liquids or solids requiring lead shielding to meet DOT radiation requirements (liquids in Duraglass bottles only). 
I.A.9

ORNL Photo 0176-81

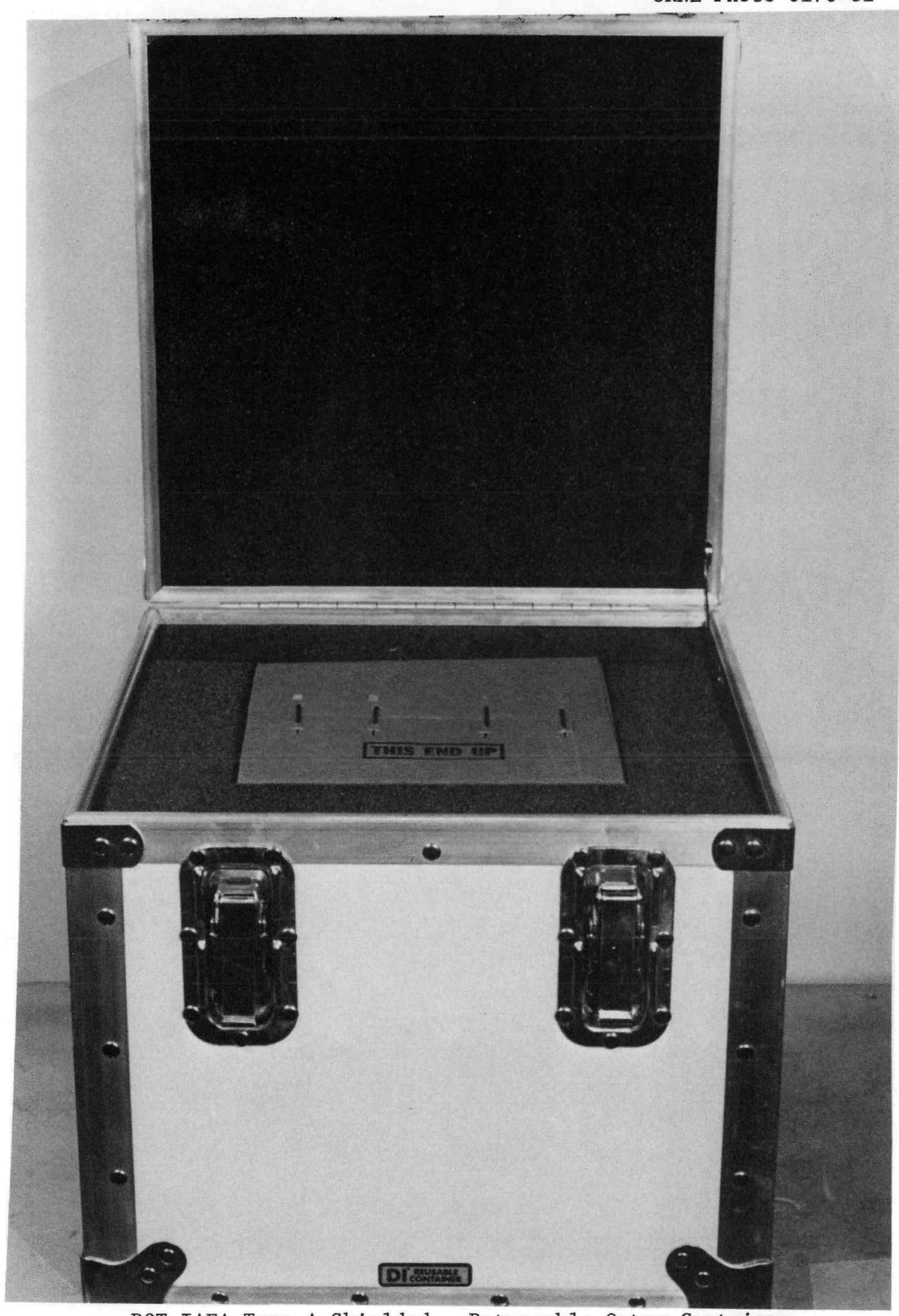

DOT IAEA Type A Shielded - Returnable Outer Container (15 in. by 15 in. by 15 in.)

Revised 3/1/81 


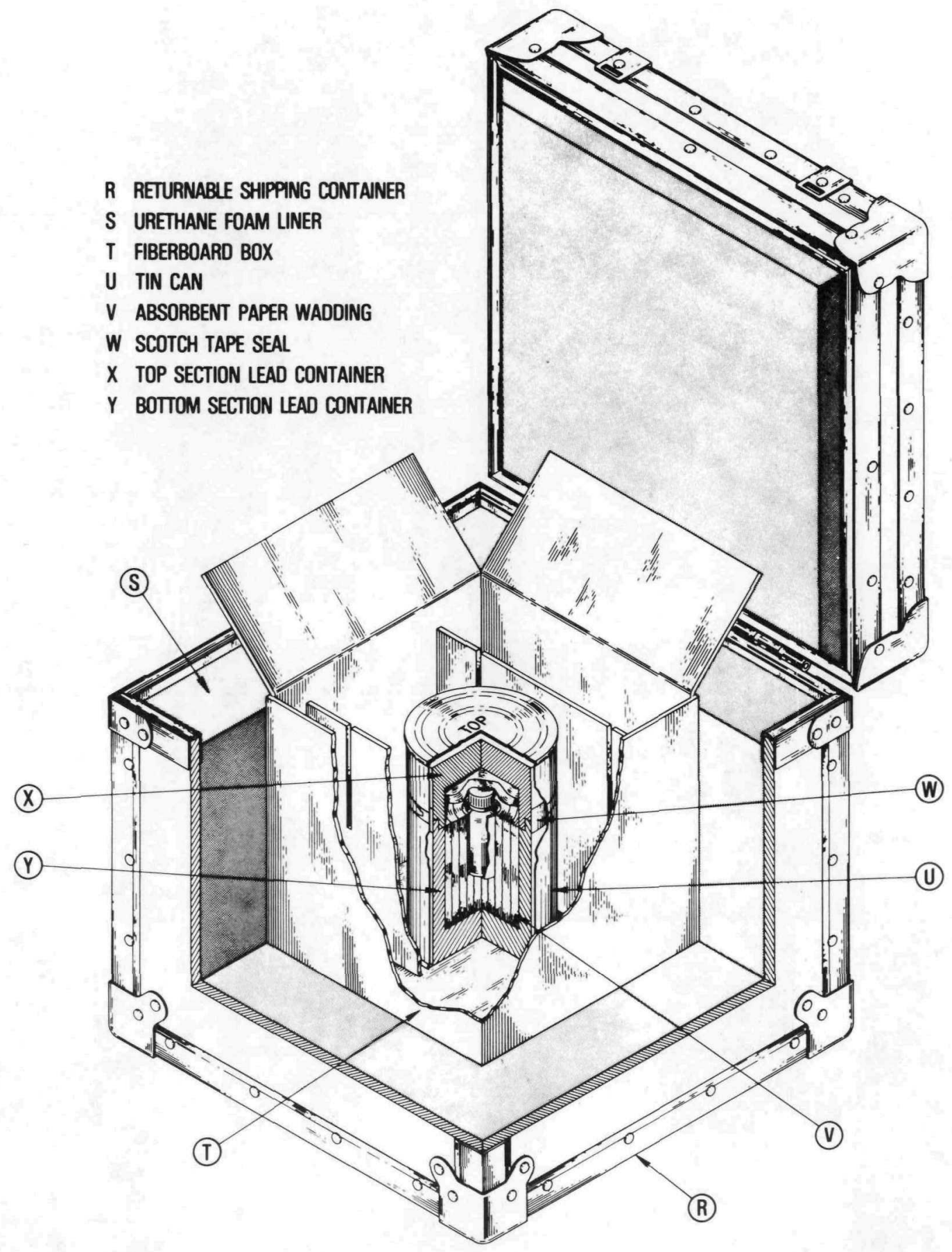

DOT-IAEA Type A Returnable Container

Revised $3 / 1 / 81$ 
DOT-IAEA TYPE A

ORNL SHIPPING CONTAINERS

A. Radioactive Liquids and Solids

\section{Shielded - Returnable}

Size: $17.5^{\prime \prime} \times 17.5^{\prime \prime} \times 16.5^{\prime \prime}-2.0$ in. lead

$21.5^{\prime \prime} \times 21.5^{\prime \prime} \times 16.5^{\prime \prime}-2.5$ and 3.0 in. lead

Inner Containment: Duraglass bottle (15-100 cc) or Special Form capsule in an "0" ring sealed stainless steel container.

Outer Containment: Stainless steel clad lead container with "0" ring seal under bolted lid.

$$
\begin{aligned}
\text { Weight: } & 2.0 \text { in. lead }-136 \text { lbs. } \\
& 2.5 \text { in. lead }-198 \text { lbs. } \\
& 3.0 \text { in. lead - } 212 \text { lbs. }
\end{aligned}
$$

Radioactive Materials: All Type A quantities of radioactive liquids or solids requiring lead shielding to meet DOT regulations on radiation readings (liquids in Duraglass bottles only).

Revised 3/1/81 
I.A. 12

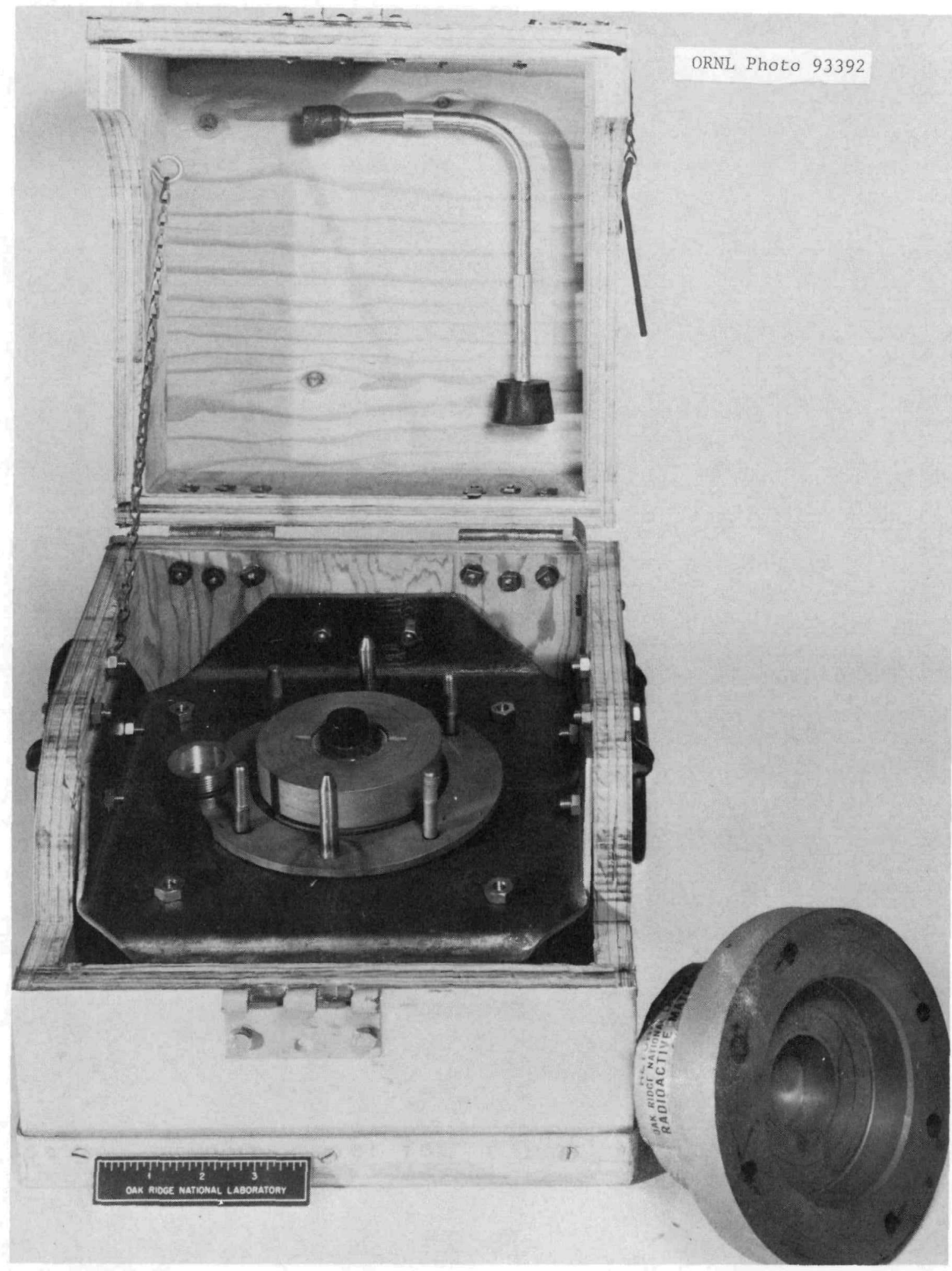

ORNL Returnable Type A Container 
NOTES:

(a) RETURNABLE SHIPPING CONTAINERS ARE IN THREE SIZES: 12 in. $\times 12$ in., 17 in. $\times 17$ in., 21 in. $\times 21$ in.

(b) THICKNESS OF LEAD SHIELDING VARIES FROM $1 \frac{1}{2}$ in. TO 3 in.

(c) VOLUME SIZE OF SHIPMENT FROM $15 \mathrm{ml}$ TO $200 \mathrm{ml}$

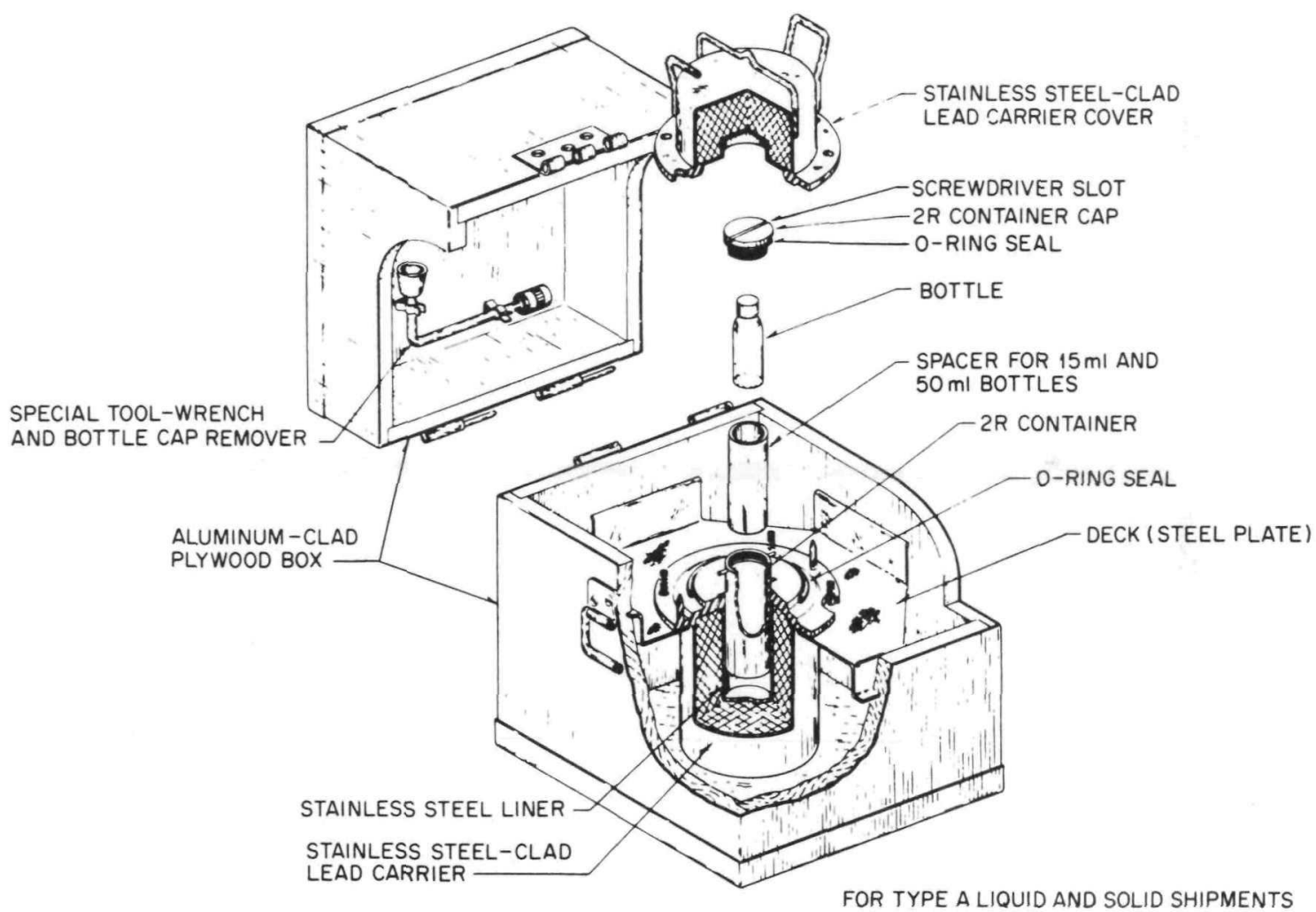

ORNL RETURNABLE SHIELDED SHIPPING

CONTAINER; USA DOT-TA TYPE A 


\section{I.B.1}

DOT-IAEA TYPE A

ORNL SHIPPING CONTAINERS

B. Radioactive Solids Only

\section{Cyclotron Target - 1" Lead}

Size: $123 / 8^{\prime \prime} \times 121 / 2 " \times 6 "$

Inner Containment: Metallic target.

Outer Containment: Stainless steel clad lead container with neoprene gasket under shield cover.

Weight: 129 1bs.

Radioactive Materials: All Type A quantities produced on a cyclotron target. 
I.B.2

ORNL-DWG 78-10542

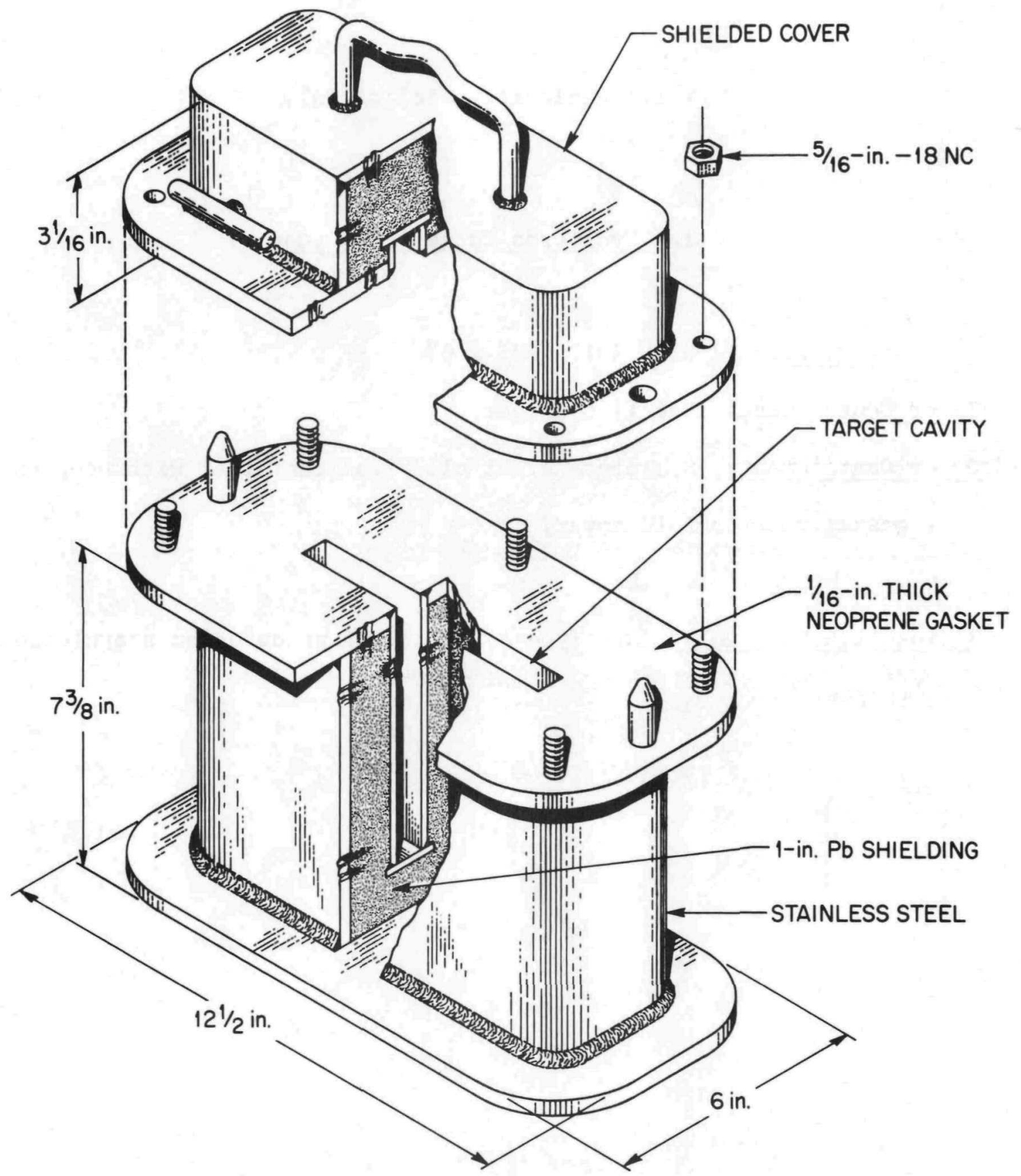

TYPE A ORNL RETURNABLE CYCLOTRON TARGET SHIPPING PACKAGE 1 -in. LEAD SHIELDING, WEIGHT-129 lbs 
I.B. 3

ORNL Photo 2415-78

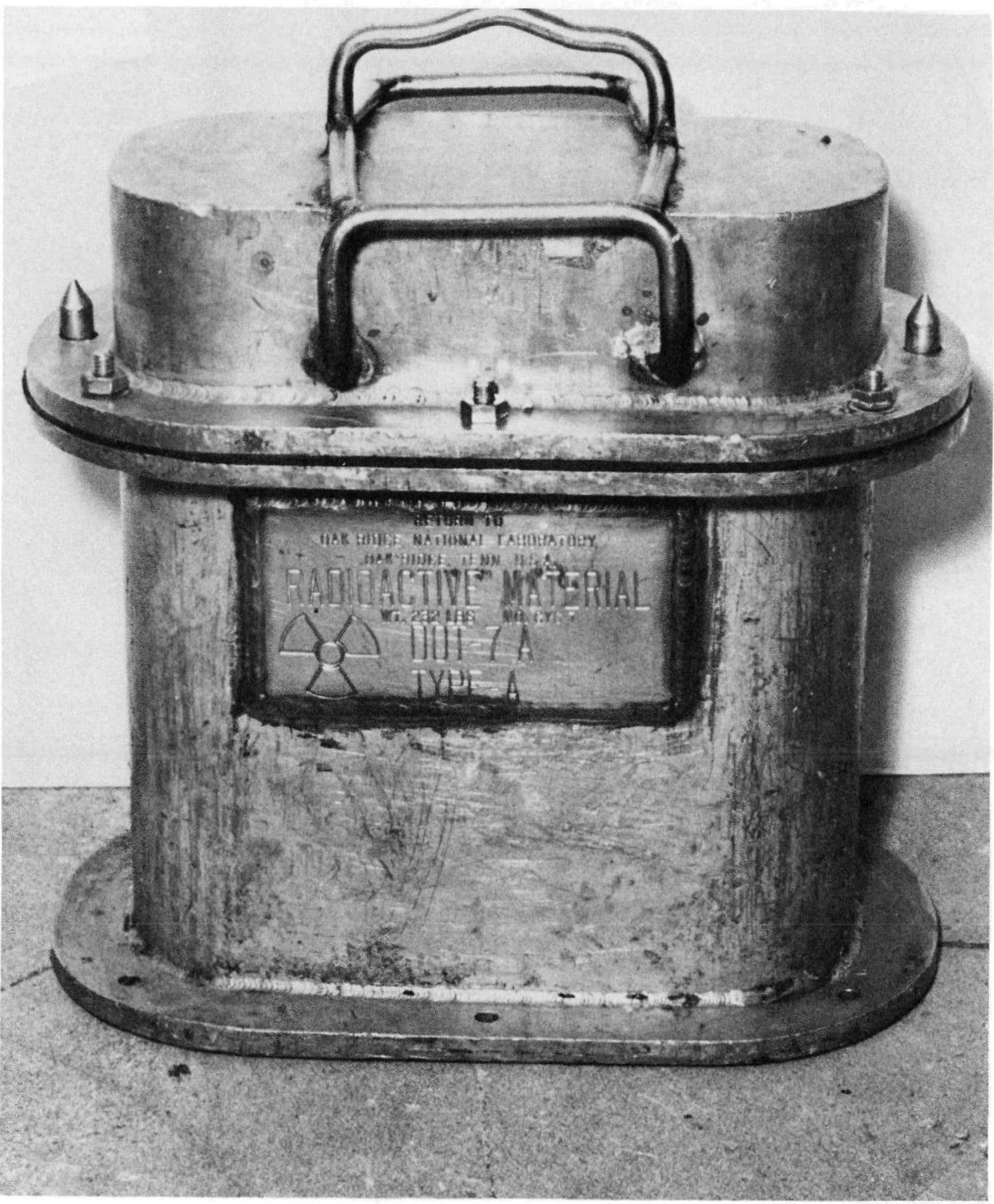

ORNL Cyclotron Target Type A Container 
0

0

- 


$$
\text { I.B. } 5
$$

DOT-IAEA TYPE A

ORNL SHIPPING CONTAINERS

B. Radioactive Solids Only

\section{Cyclotron Target -2 " Lead}

Size: $131 / 2^{\prime \prime} \times 131 / 2^{\prime \prime} \times 77 / 8^{\prime \prime}$

Inner Containment: Metallic target.

Outer Containment: Stainless steel clad lead container with neoprene gasket under shield cover.

Weight: $2851 \mathrm{bs}$.

Radioactive Materials: All Type A quantities produced on a cyclotron target. 


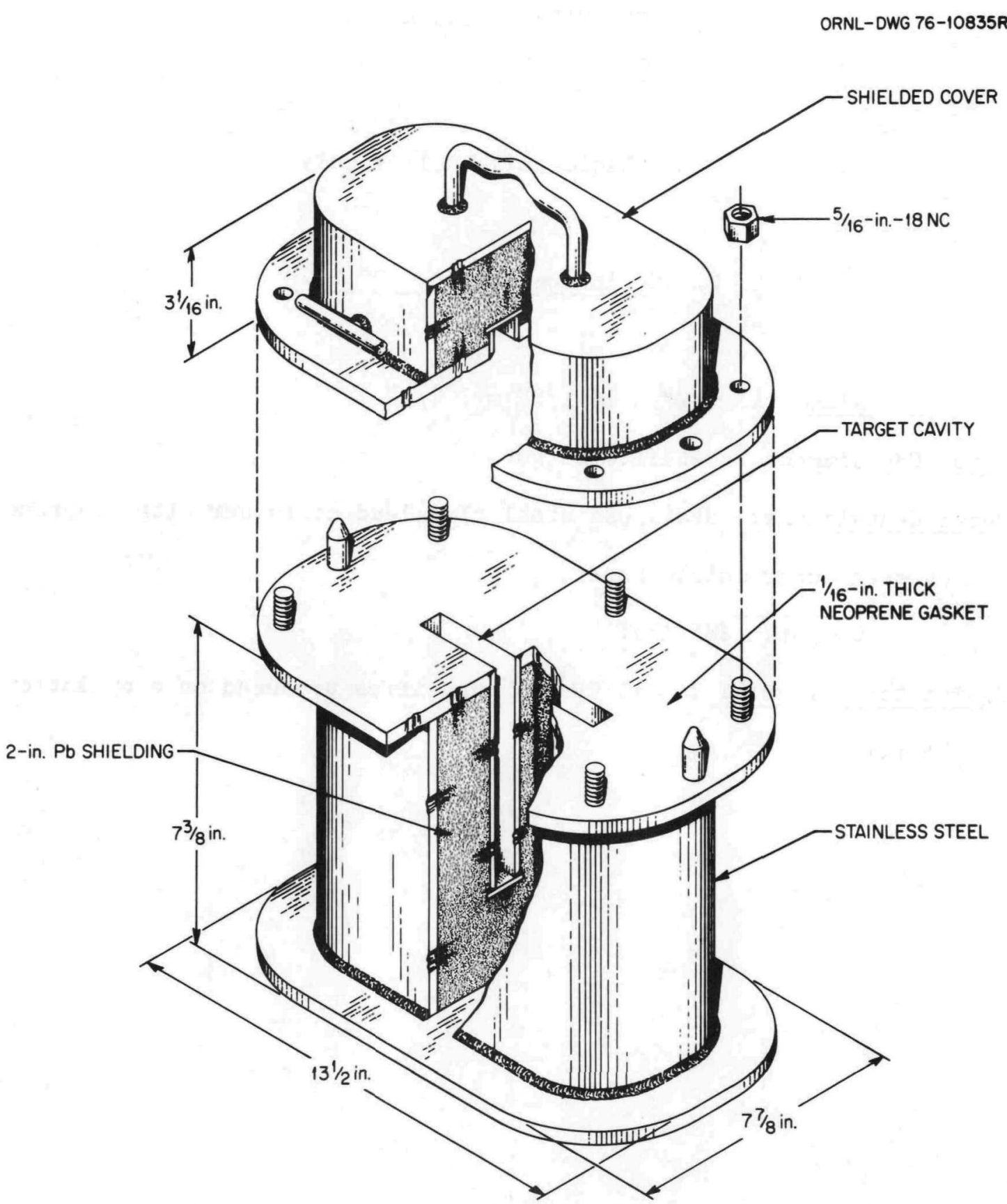

TYPE A ORNL RETURNABLE CYCLOTRON TARGET SHIPPING PACKAGE 2 -in. LEAD SHIELDING, WEIGHT-285 Ibs 


$$
\text { I.B. } 7
$$

DOT-IAEA TYPE A

ORNL SHIPPING CONTAINERS

B. Radioactive Solids On1y

\section{Cyclotron Target -4 " Lead}

Size: $155 / 8^{\prime \prime} \times 181 / 4^{\prime \prime} \times 12^{\prime \prime}$

Inner Containment: Metallic target.

Outer Containment: Stainless steel clad lead container with neoprene gasket under shield cover.

Weight: 400 1bs.

Radioactive Materials: All Type A quantities produced on a cyclotron target. 


\section{I.B. 8}

ORNL Photo 6386-76

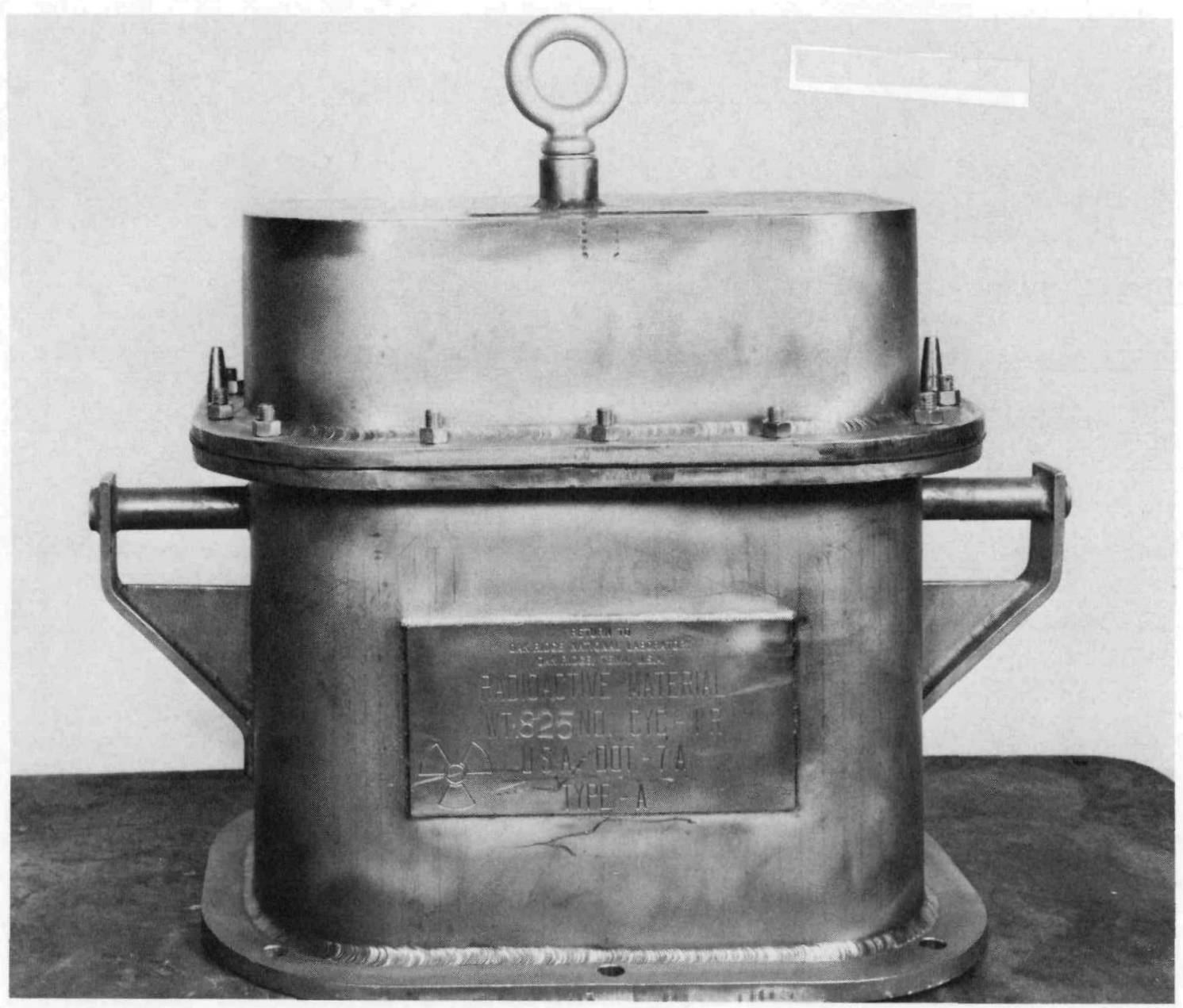

ORNL Cyclotron Target Type A Container 


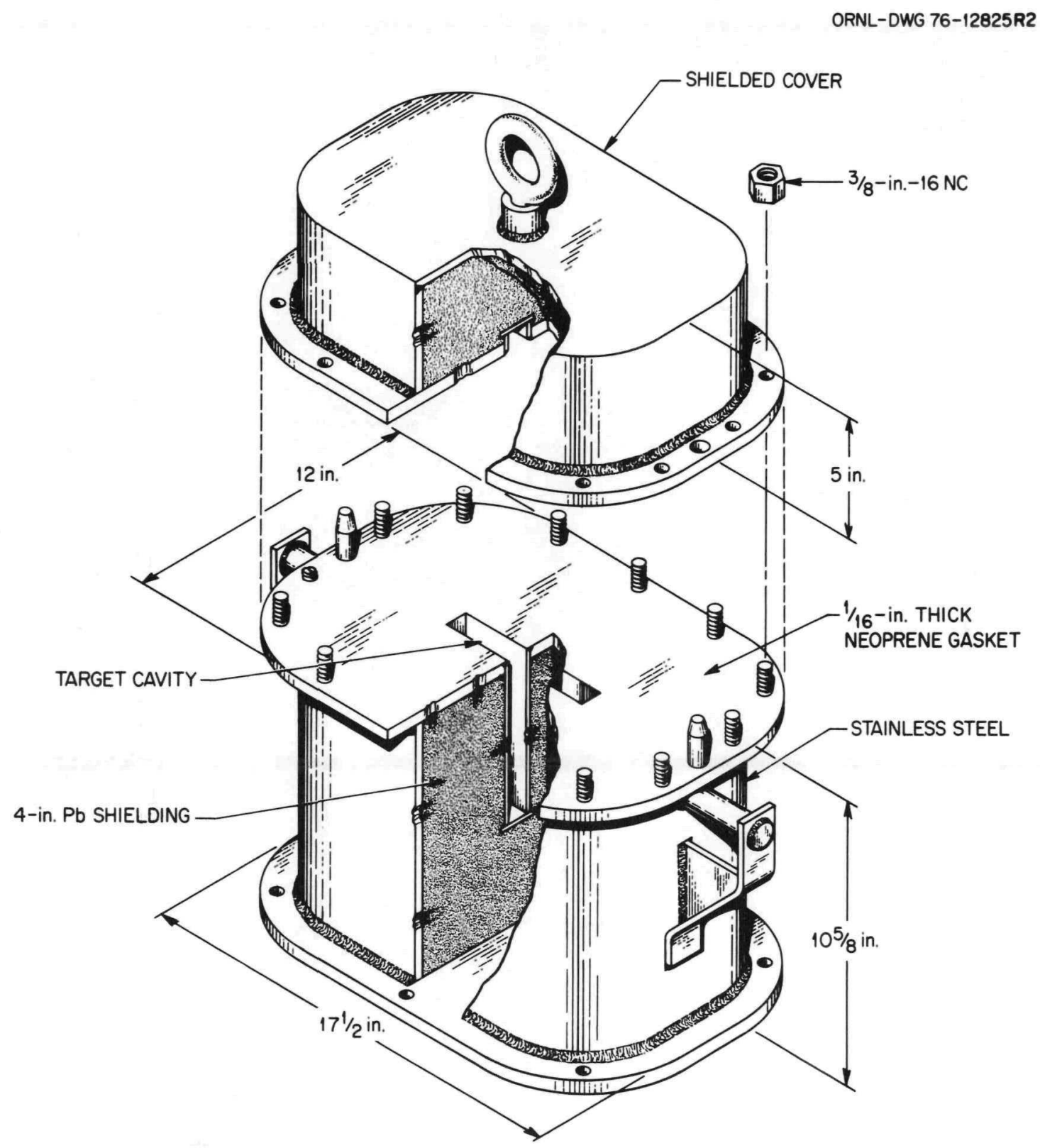

ORNL RETURNABLE CYCLOTRON TARGET SHIPPING PACKAGE 4 -in. LEAD SHIELDING, WEIGHT-800 Ibs 
-

-

- 


\section{I.B. 11}

DOT-IAEA TYPE A

ORNL SHIPPING CONTAINERS

B. Radioactive Solids On1y

4. TRU Neutron Shipping Container

Size: $44 "$ O.D. $\times 48$ " high

Inner Containment: Special Form capsules.

Outer Containment: Steel container with water extended polyester filling.

Weight: $37001 \mathrm{bs}$.

Radioactive Materials: All Type A quantities of radioactive solids requiring neutron shielding to meet DOT radiation requirements. 


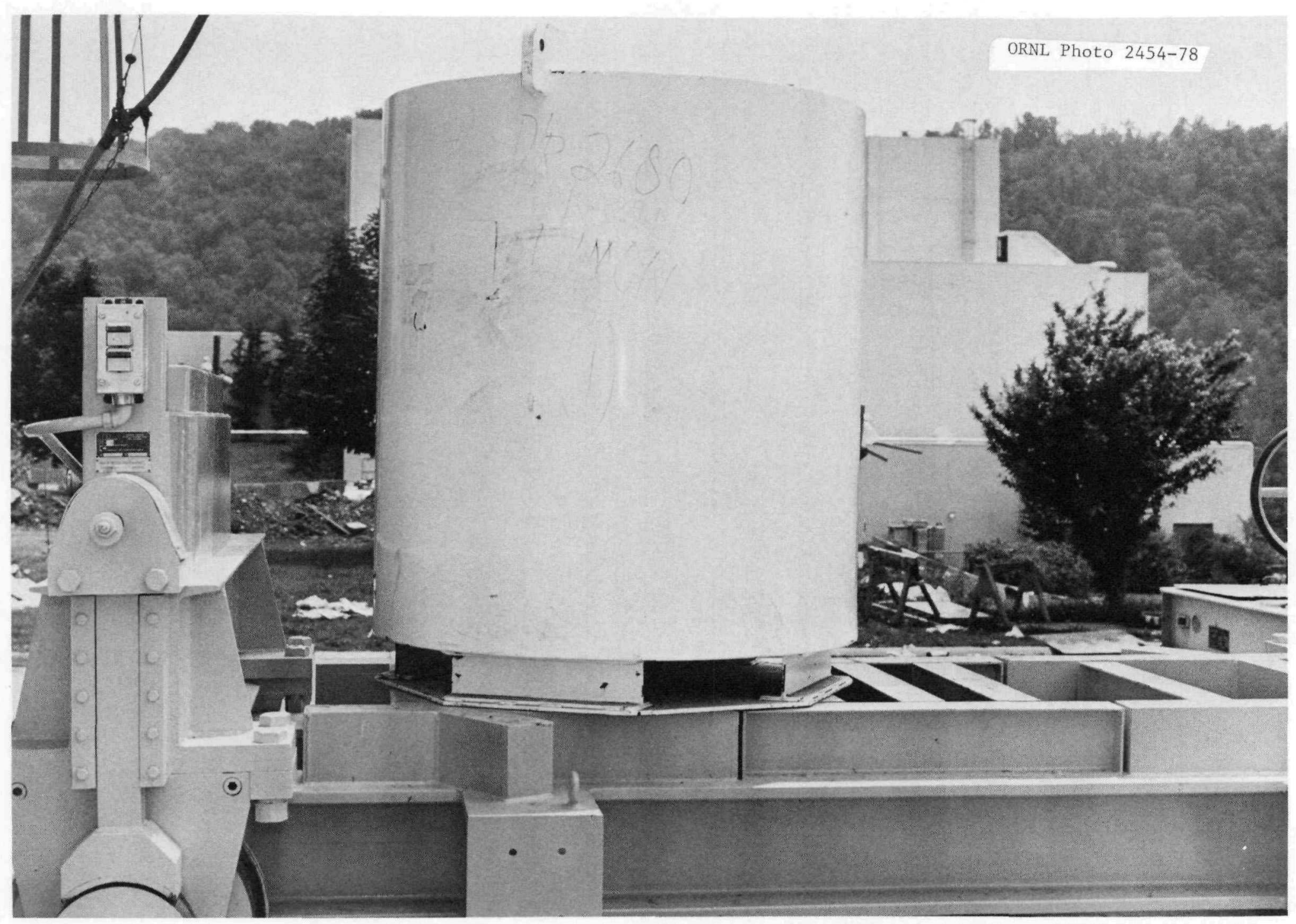

TRU Neutron Shipping Container - Type A 


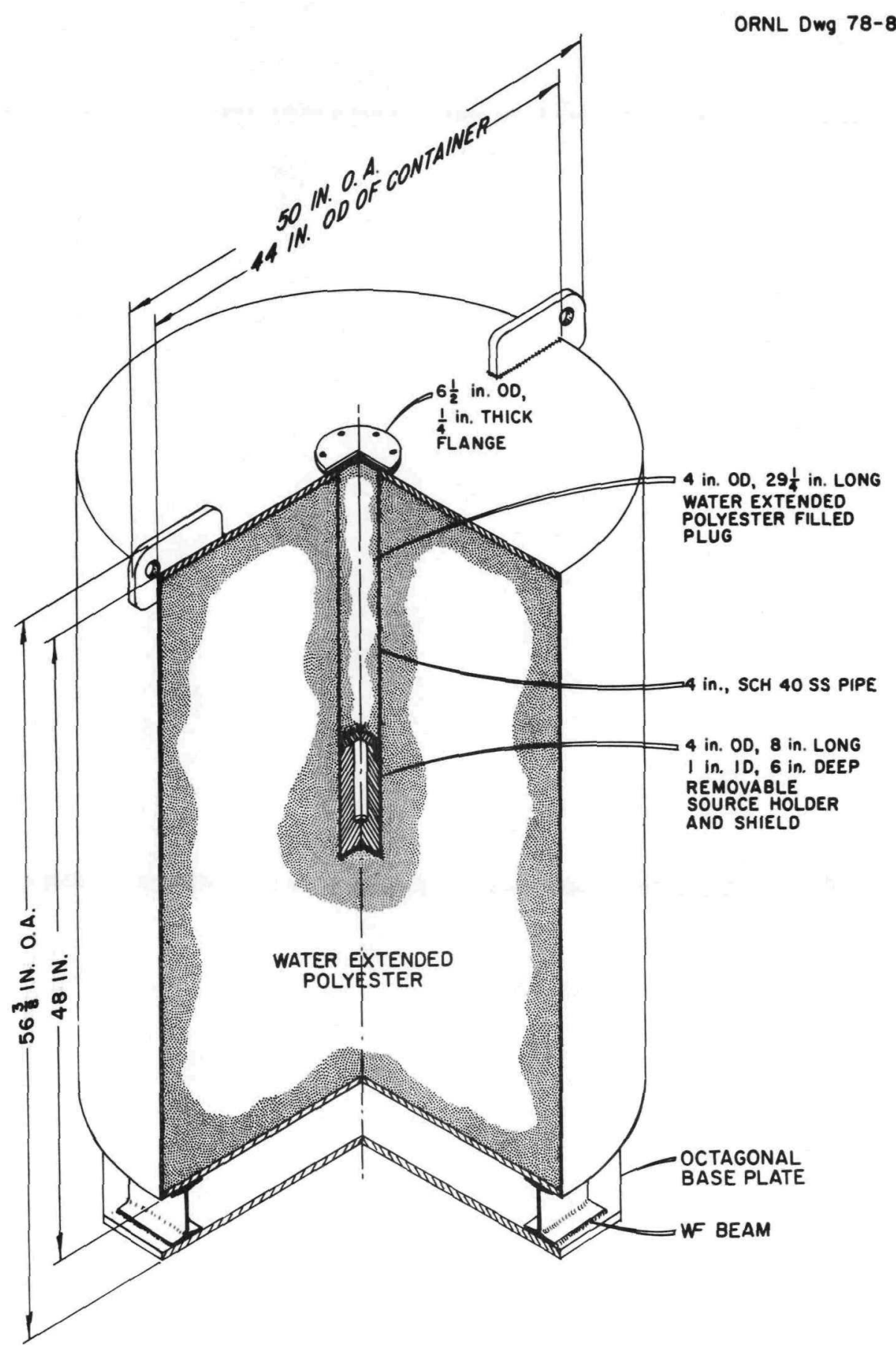

TRU NUCLEAR SHIPPING CONTAINER (TYPE A)

(ATKINSON STEEL CO., SERIAL No. 241)

Gross wt. 3700 lbs 
DOT-IAEA TYPE A

ORNL SHIPPING CONTAINERS

C. Radioactive Gases

\section{Shie1ded - Non-Returnable}

Size: $8 " \times 8 " \times 8$ " or $12 " \times 12 " \times 12 "$

Inner Containment: Glass ampule in a sealed lead shield which is placed in a schedule 40 steel pipe nipple. Absorbent material is wrapped around steel pipe for cushioning. Ampule volume is normally 5 cc. Outer Containment: DOT SPEC 2N tin can in cardboard (12B) box with protective cardboard inserts.

Weight: 4 lbs.

Radioactive Materials: All Type A quantities of radioactive gases requiring minimal shielding. All gas pressures are less than atmospheric. 


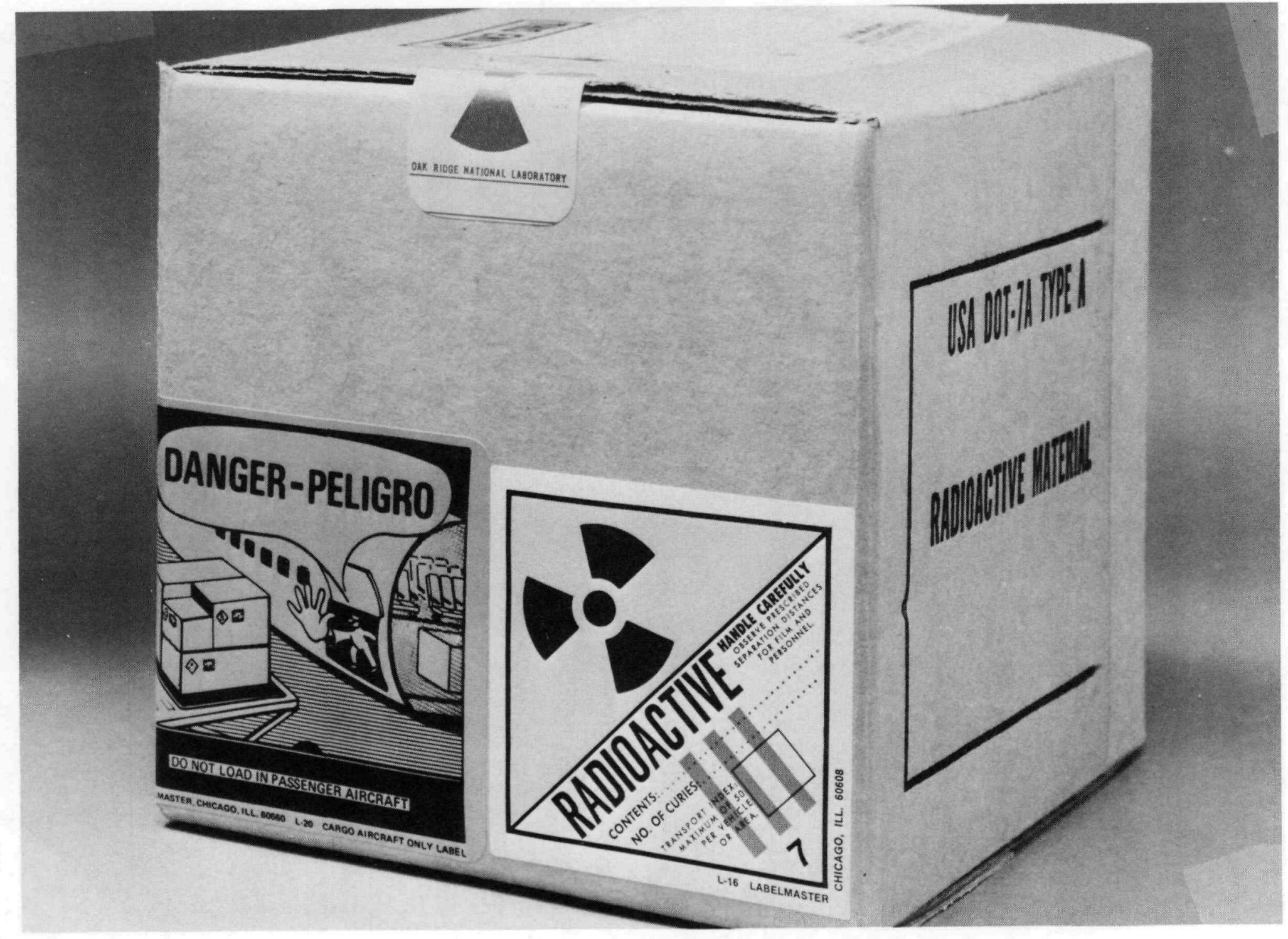

ORNL Non-Returnable Type A Package ( 8 in. by 8 in. by 8 in.) 
I.C. 3

ORNL-DWG 76-3863R

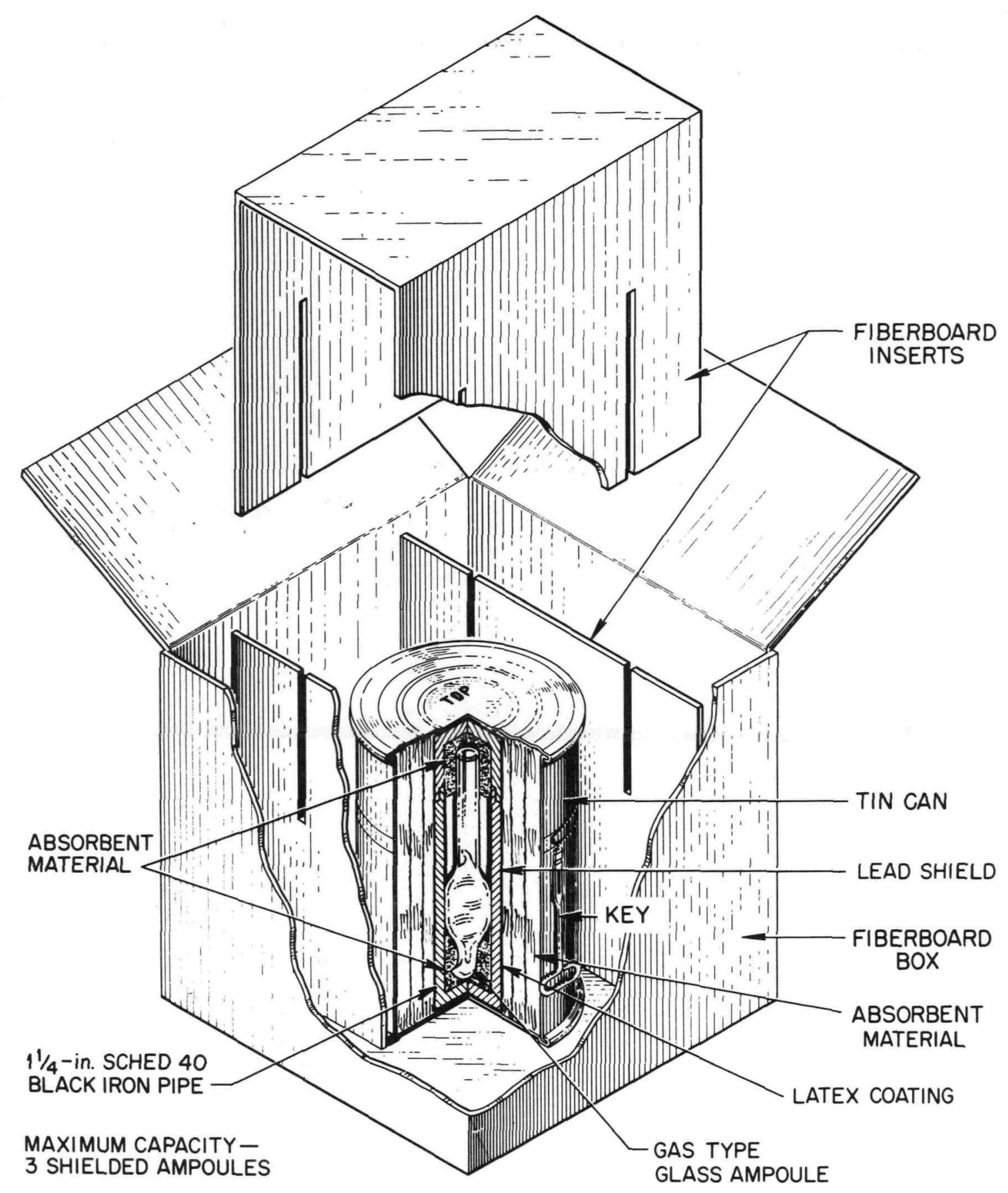

DISPOSABLE CONTAINER FOR RADIOACTIVE GAS SHIPMENTS 
I. C. 4

Blank 
I.C.5

DOT-IAEA TYPE A

ORNL SHIPPING CONTAINERS

C. Radioactive Gases

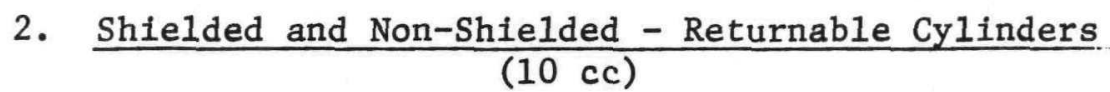

Size: 3 1/2" O.D. x 7 5/16" long

Inner Containment: Stainless steel cylinder (10 cc volume) with a bellows sealed valve.

Outer Containment: Stainless steel cylinder with "0" ring seal under valve cap. Lead shielded between inner and outer containment for gases requiring shielding.

Weight: Without 1ead - 6 1bs.

With lead - 9 1bs.

Radioactive Materials: All Type A quantities of radioactive gases such as tritium, xenon-133, and krypton-85. Lead shielding is used on xenon-133 and krypton-85 to meet DOT regulations on radiation readings. Al1 gas pressures are less than atmospheric. 
ORNL-DWG 77-19132AR

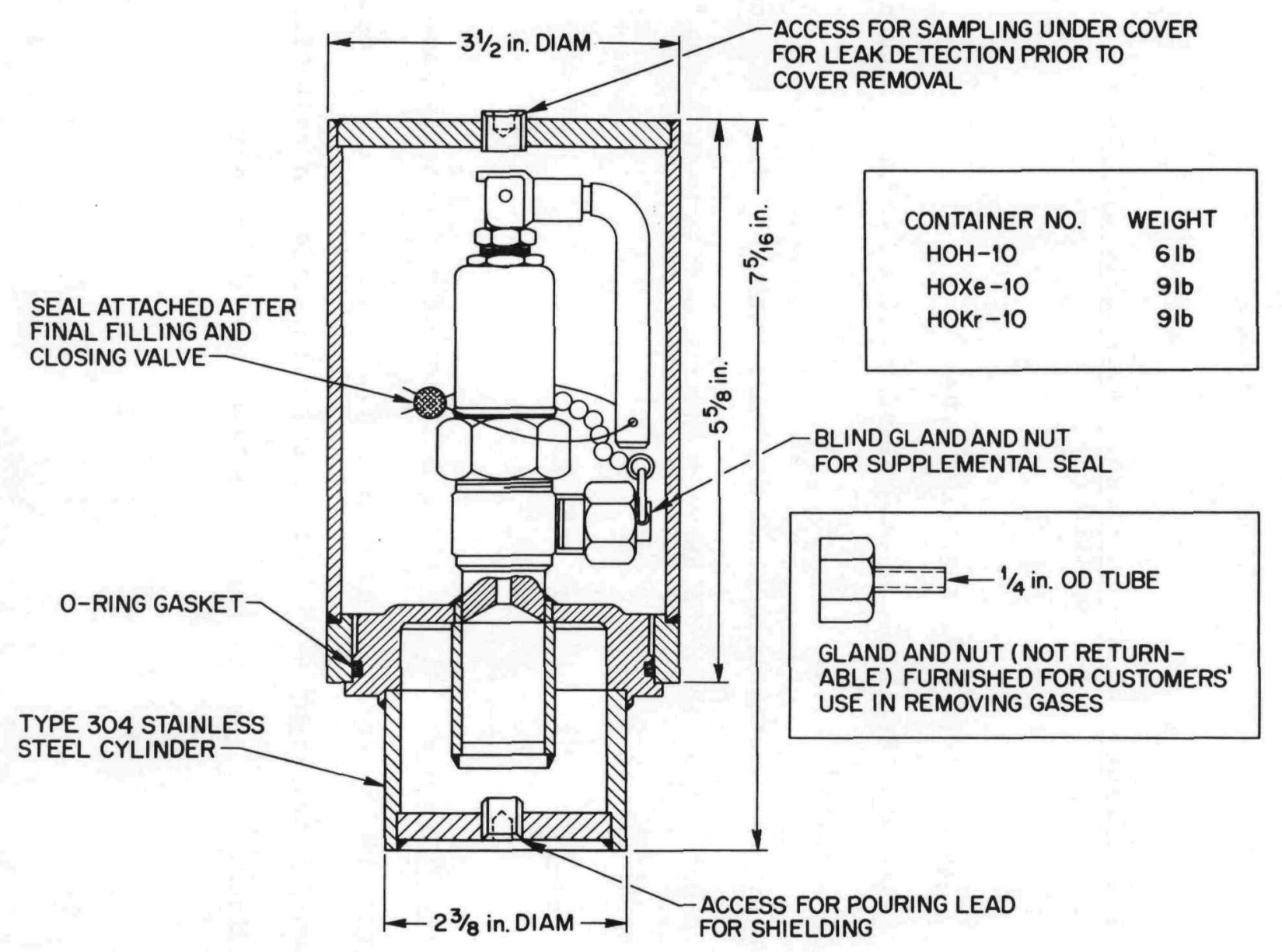

ORNL RETURNABLE GAS CYLINDER - USA DOT TA TYPE A

$10 \mathrm{cC}$ ISOTOPE CONTAINER 
I.C.7

DOT-IAEA TYPE A

ORNL SHIPPING CONTAINERS

C. Radioactive Gases

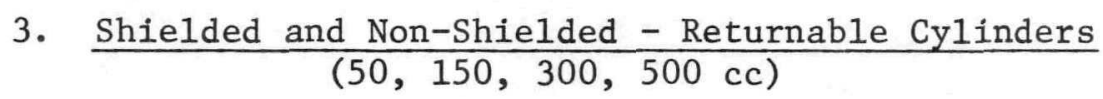

Size: See ORNL Dwg. 77-19134R

Inner Containment: Stainless steel cylinder (50-500 cc volume) with a bellows sealed valve.

Outer Containment: Stainless steel cylinder with "0" ring seal under valve cap. Lead shielded between inner and outer containment for gases requiring shielding.

Weight: See ORNL Dwg. 77-19134R

Radioactive Materials: All Type A quantities of radioactive gases such as tritium, xenon-133, and krypton-85. Lead shielding is used on xenon-133 and krypton-85 to meet DOT regulations on radiation readings. All gas pressures are less than atmospheric. 


\section{I.C. 8}

ORNL Photo 2542-78

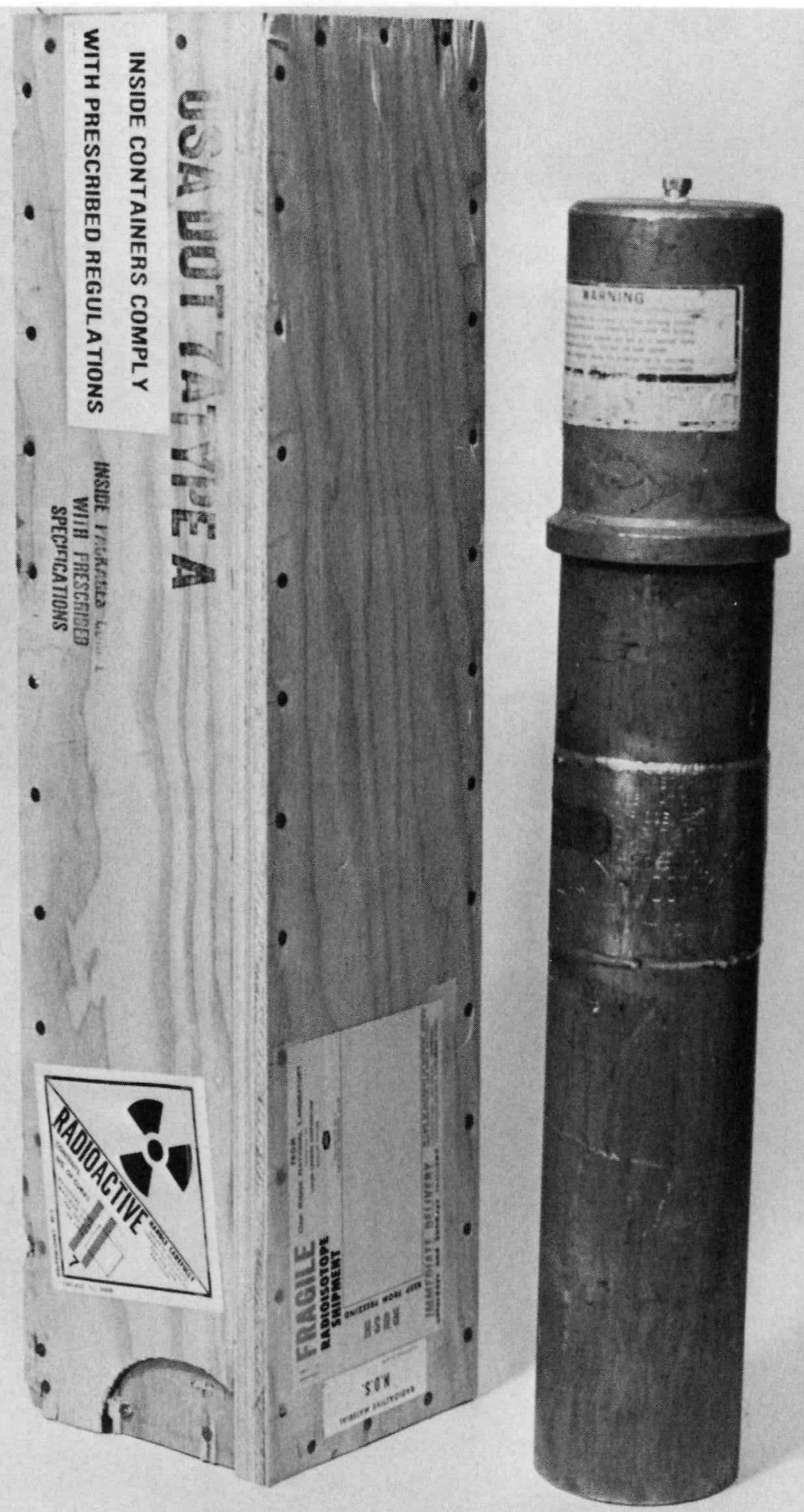

ORNL Gas Container - Type A 


\section{I.C. 9}

ORNL Photo 2543-78
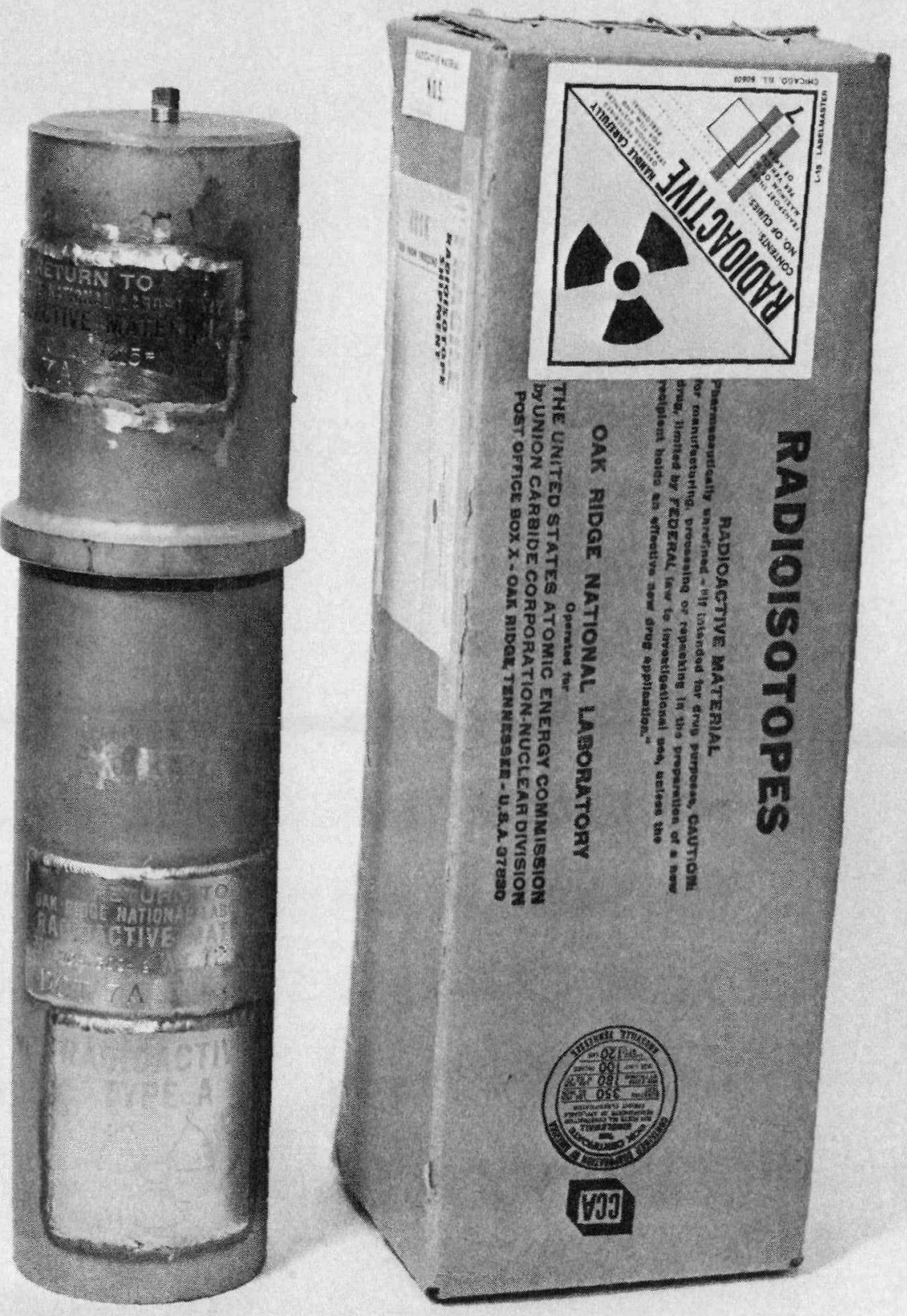

ORNL Gas Container - Type A 
ORNL-DWG 77-19134R

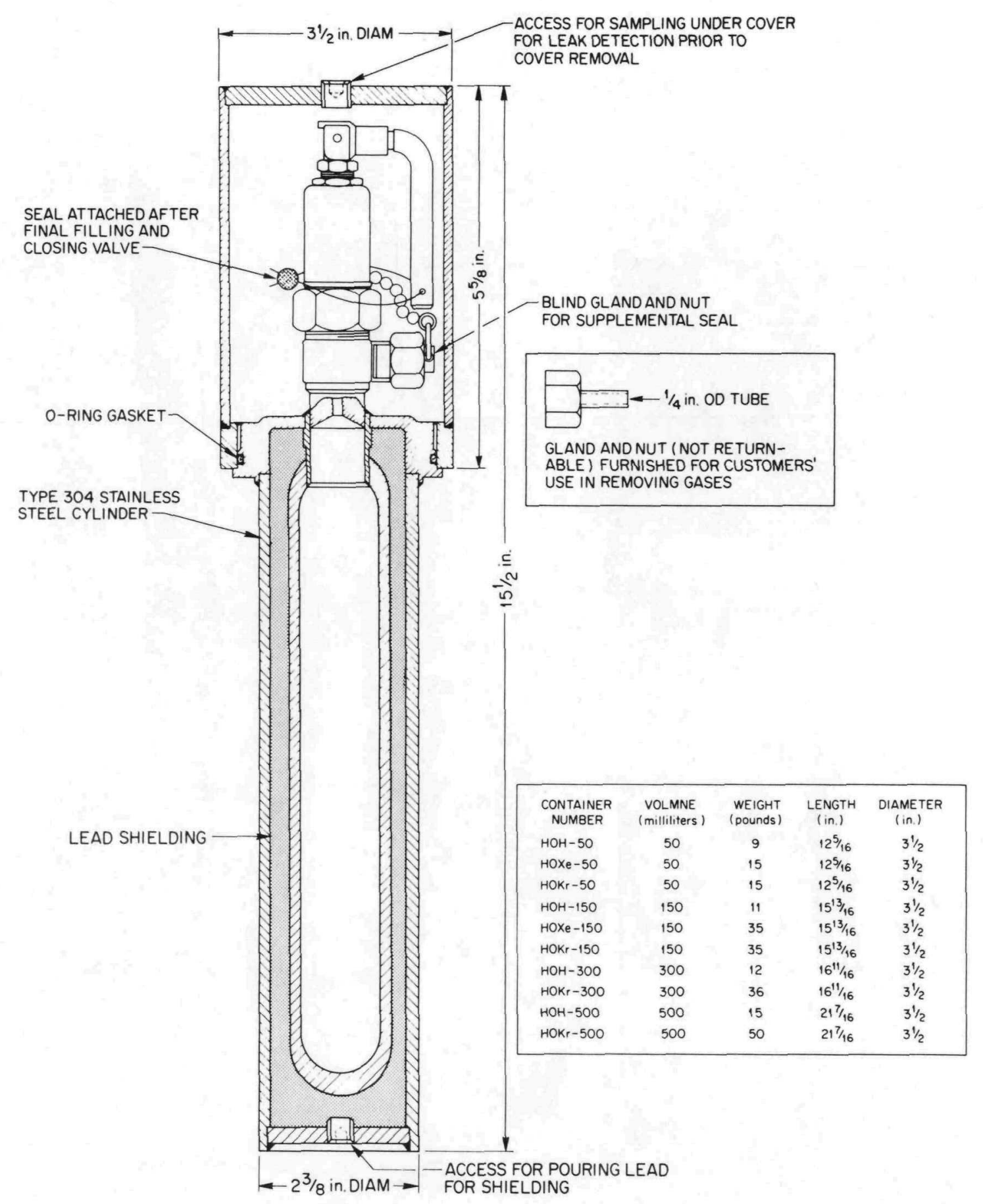

ORNL RETURNABLE GAS CYLINDER - USA DOT TA TYPE A 
DOT-IAEA TYPE A

ORNL SHIPPING CONTAINERS

C. Radioactive Gases

4. Shielded and Non-Shielded - Returnable Cylinders

(1000 cc)

Size: See ORNL Dwg. 75-16651R

Inner Containment: Stainless steel cylinder (1000 cc volume) with a bellows sealed valve.

Outer Containment: Stainless steel cylinder with "0" ring sea1 under valve cap. Lead shielded between inner and outer containment for gases requiring shielding. Gas cylinder placed in 20WC fire and impact shield for transport.

Weight: See ORNL Dwg . 75-16651R

Radioactive Materials: All Type A quantities of radioactive gases such as tritium, xenon-133 and krypton-85. Lead shielding is used on xenon-133 and krypton-85 to meet DOT regulations on radiation readings. All gas pressures are less than atmospheric.

Revised $3 / 1 / 81$ 
I.C. 12

ORNL Photo 0174-81

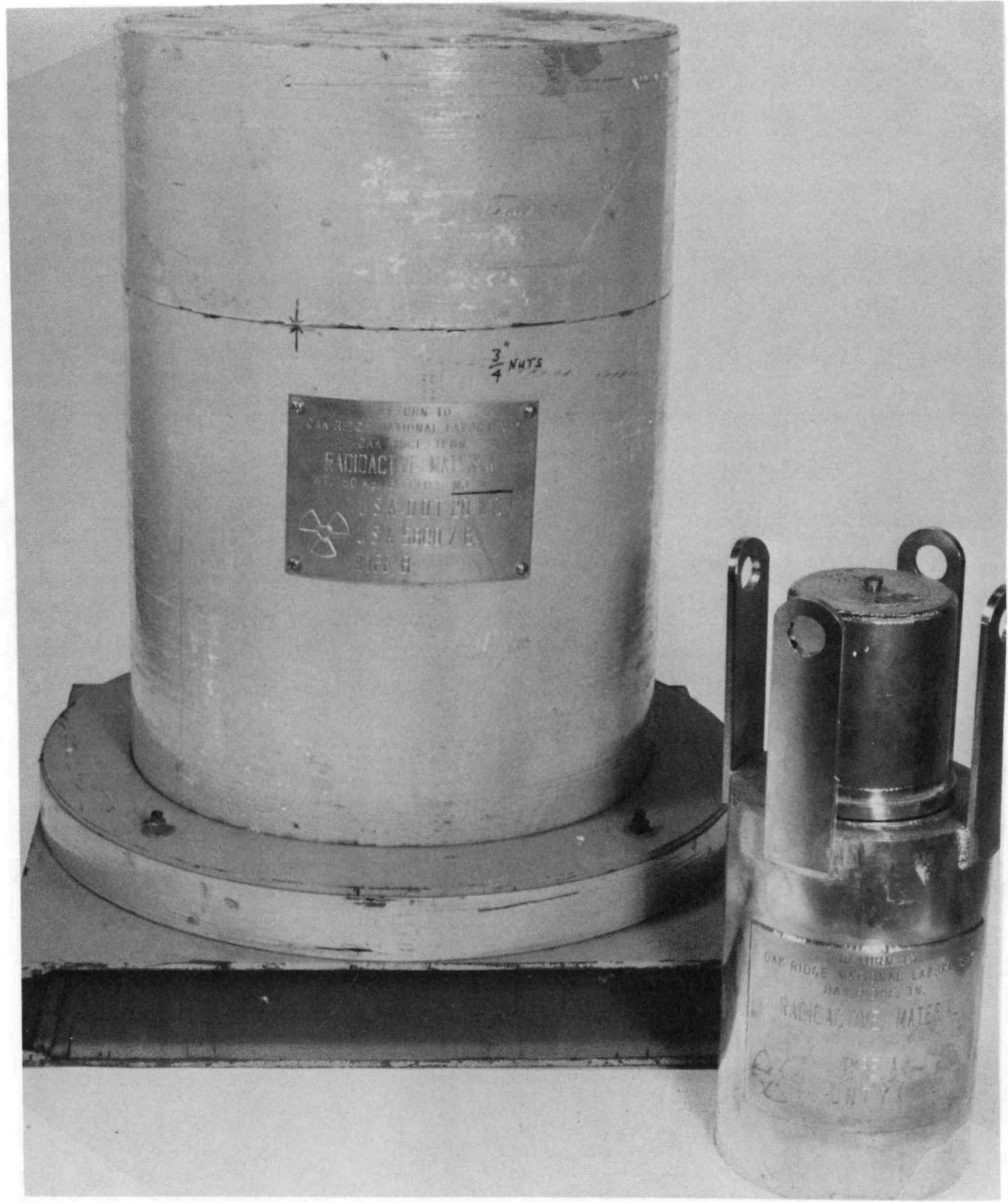

Revised 3/1/81

ORNL Gas Package - Type A 
ORNL-DWG 75-16651R

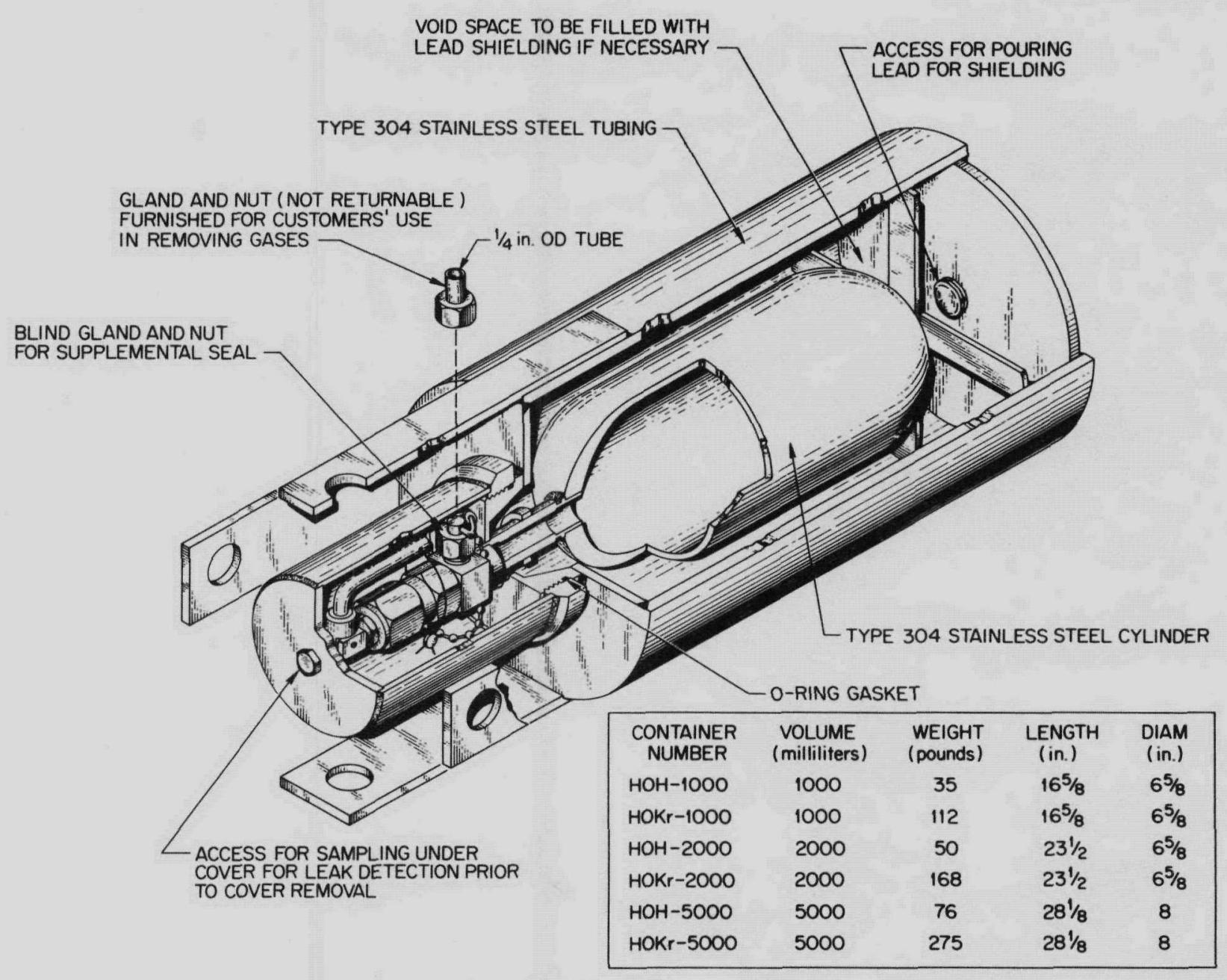

ORNL RETURNABLE GAS CYLINDER; USA DOT TA TYPE A 
0

0

0 
DOT-IAEA TYPE A

ORNL SHIPPING CONTAINERS

C. Radioactive Gases

5. Non-Shielded - Non-Returnable

(1000 cc)

Size: 2" O.D. x $251 / 2$ " Long (Cylinder)

$311 / 2$ " x $51 / 2 "$ x $51 / 2 "$ (Plywood box)

Inner Containment: Stee1 gas cylinder (1000 cc) with an "0" ring sealed valve.

Outer Containment: Plywood box.

Weight: Cylinder - 3 lbs.

Cylinder and Plywood Box - 13 1bs.

Radioactive Materials: All Type A quantities of radioactive gases not requiring lead shielding to meet DOT regulations on radiation readings. All gas pressures are less than atmospheric. 


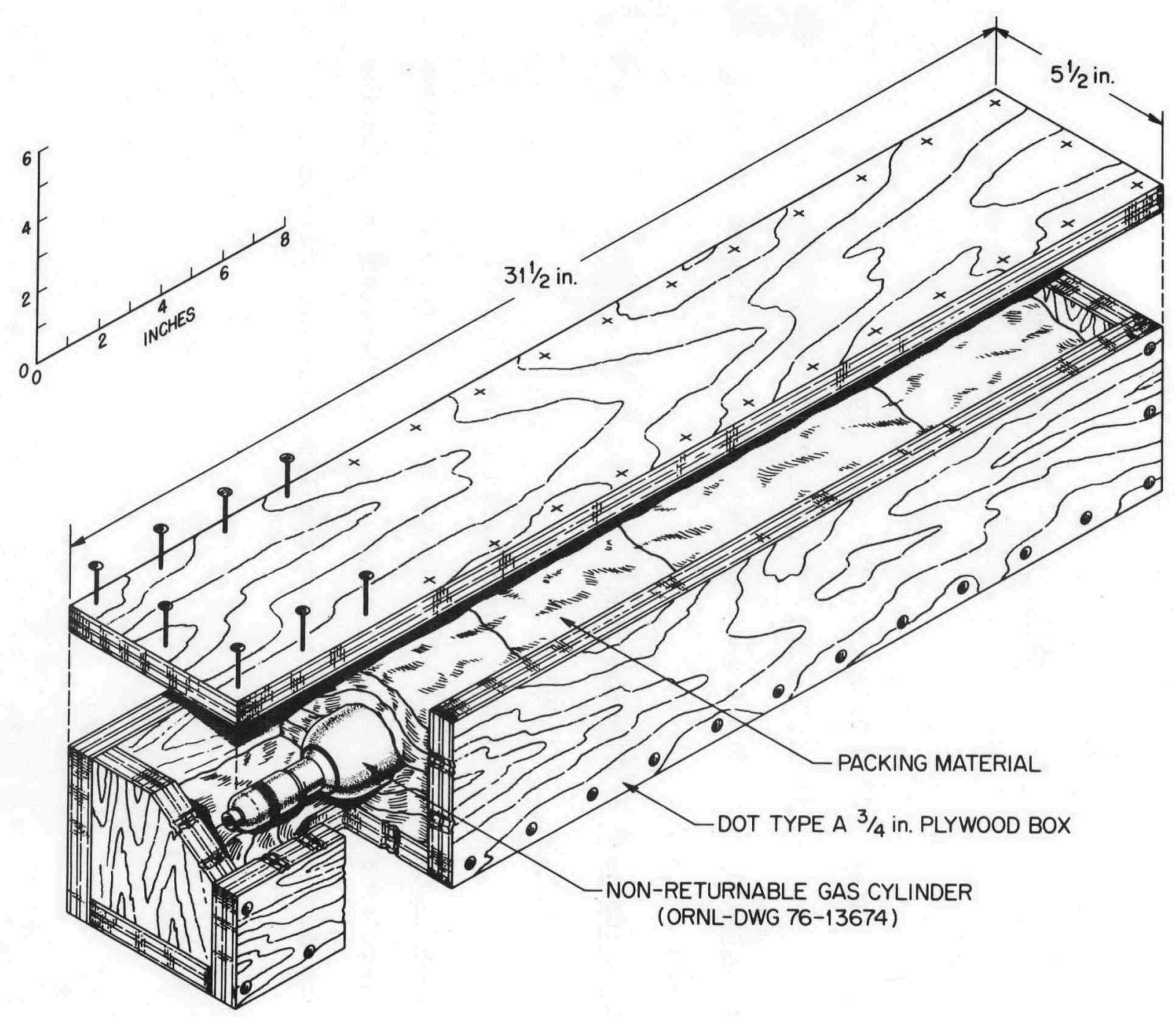

DOT Type A Shipping Package for Non-Returnable Tritium Gas Cylinder 

0

0

0 
DOT-IAEA TYPE A

ORNL SHIPPING CONTAINERS

\section{Radioactive Gases}

\section{Shielded Cylinder - Impact Shield}

Size: $241 / 8^{\prime \prime}$ O.D. $\times 417 / 8$ " in height

Inner Containment: Stainless steel cylinders (2000 cc and $5000 \mathrm{cc}$ volume) with bellows sealed valve.

Outer Containment: Stainless steel cylinder with "0" ring seal under valve cap. Lead shielding between inner and outer cylinders.

Cylinder placed in gas cylinder impact shield (see ORNL

Dwg. 74-8422).

Weight: 2000 cc cylinder - 168 1bs.

5000 cc cylinder - 276 lbs.

Impact shield - 320 lbs.

Radioactive Materials: All Type A quantities of gases requiring lead shielding to meet DOT regulations on radiation readings. 
ORNL Photo 2538-78

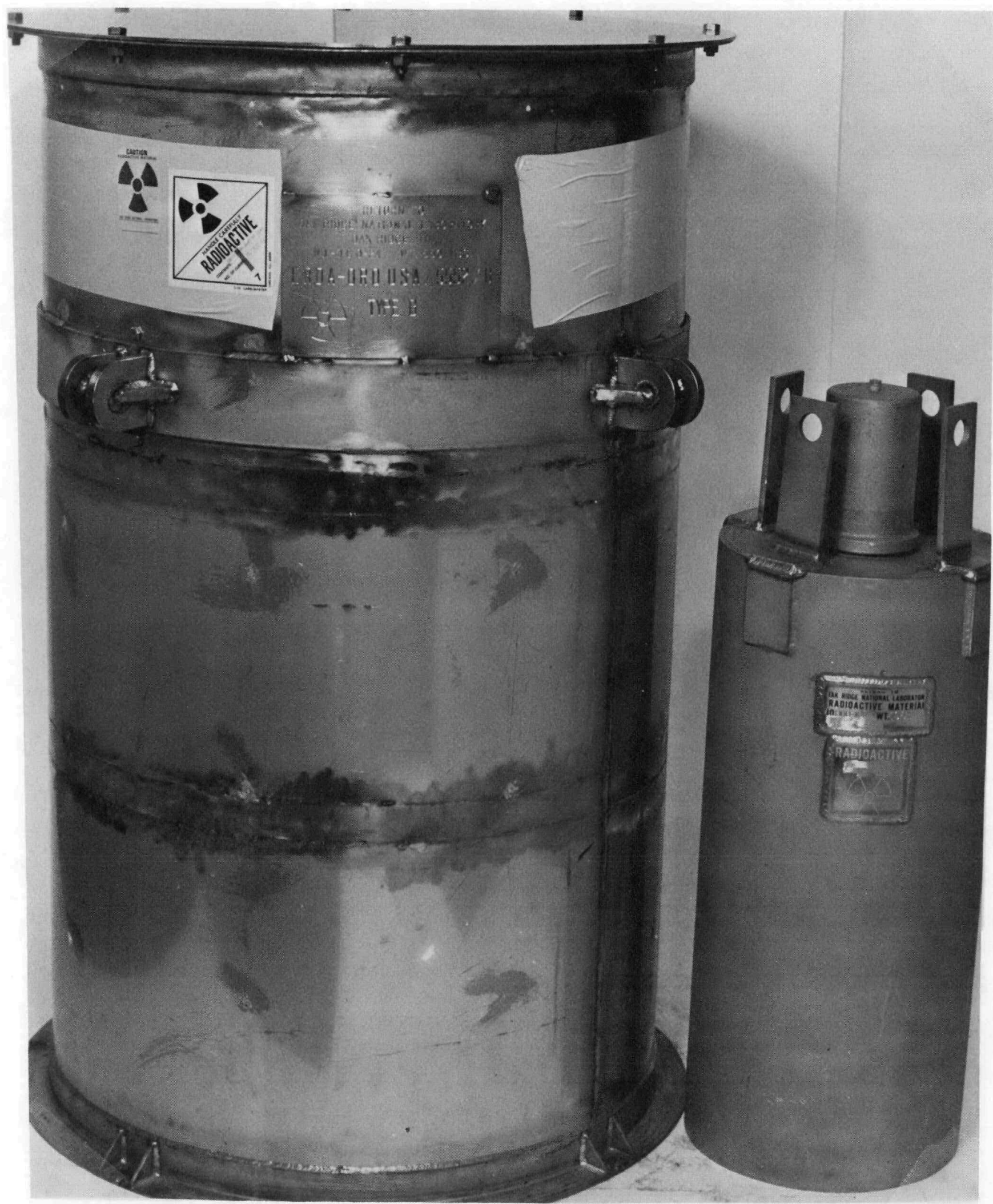

Revised 3/1/81

ORNL Gas Package - Type B 


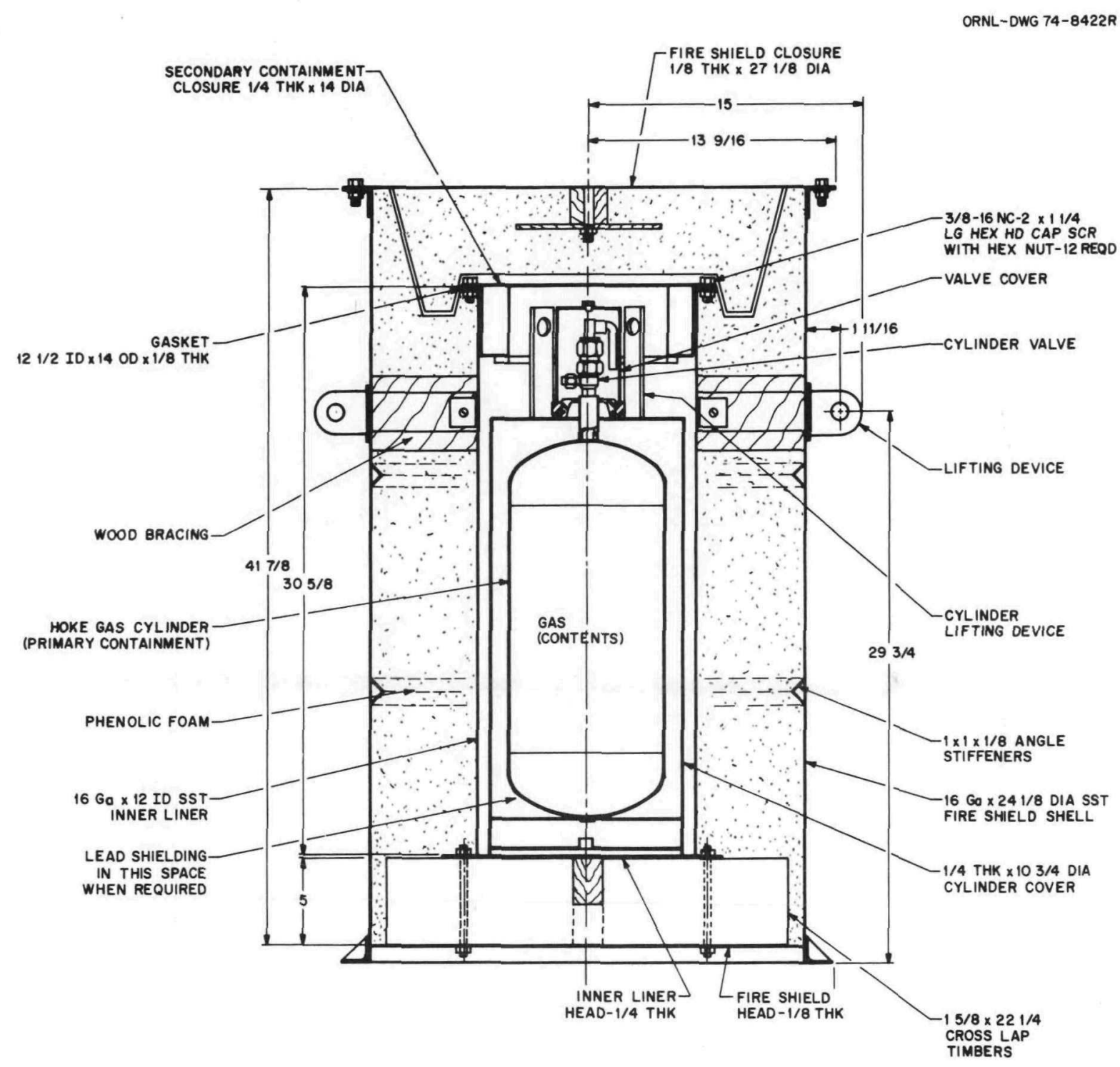

TYPE B

ALL DIMENSIONS GIVEN IN INCHES

ORNL GAS CYLINDER FIRE SHIELD

WEIGHT-320 Ibs 

II. ORNL TYPE B PACKAGES

Oak Ridge National Laboratory (ORNL) shipping containers for radioactive materials which meet the requirements of the Code of Federal Regulations (CFR) No. 49 (Transportation) and the International Atomic Energy Agency (IAEA) Safety Series No. 6 (1973) for Type B packaging are divided into two categories.
A. Radioactive Gases
B. Radioactive Solids

The quantities of radioactive material that are approved for shipment by the CFR-49 (Transportation, Part 173.389e) in a Type B package are listed below.

\begin{tabular}{|c|c|}
\hline Transport group & Type B quantity \\
\hline I............. & 20 \\
\hline II............. & 20 \\
\hline III............. & 200 \\
\hline IV............. & 200 \\
\hline 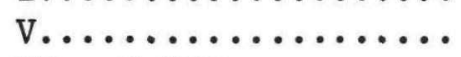 & 5,000 \\
\hline VI and VII.......... & 50,000 \\
\hline Special form........ & 5,000 \\
\hline
\end{tabular}

Large quantities of specific radionuclides can be shipped in packages approved by the Department of Energy (DOE) and the Nuclear Regulatory Commission (NRC). A Certificate of Compliance is issued by the NRC for each package and states the limits for radioactive materials than can be shipped as large quantity.

An IAEA Certificate of Competent Authority is required for all Type B shipments to foreign countries.

The transport group for each radionuclide can be determined from Table I. 
-

-

-

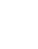

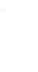


II.A. 1

\section{A. RADIOACTIVE GASES}

GAS CYLINDER FIRE AND IMPACT SHIELD

$(2000,5000,16000 \mathrm{cc})$ 
II. A. 2

ORNL Photo 2538-78

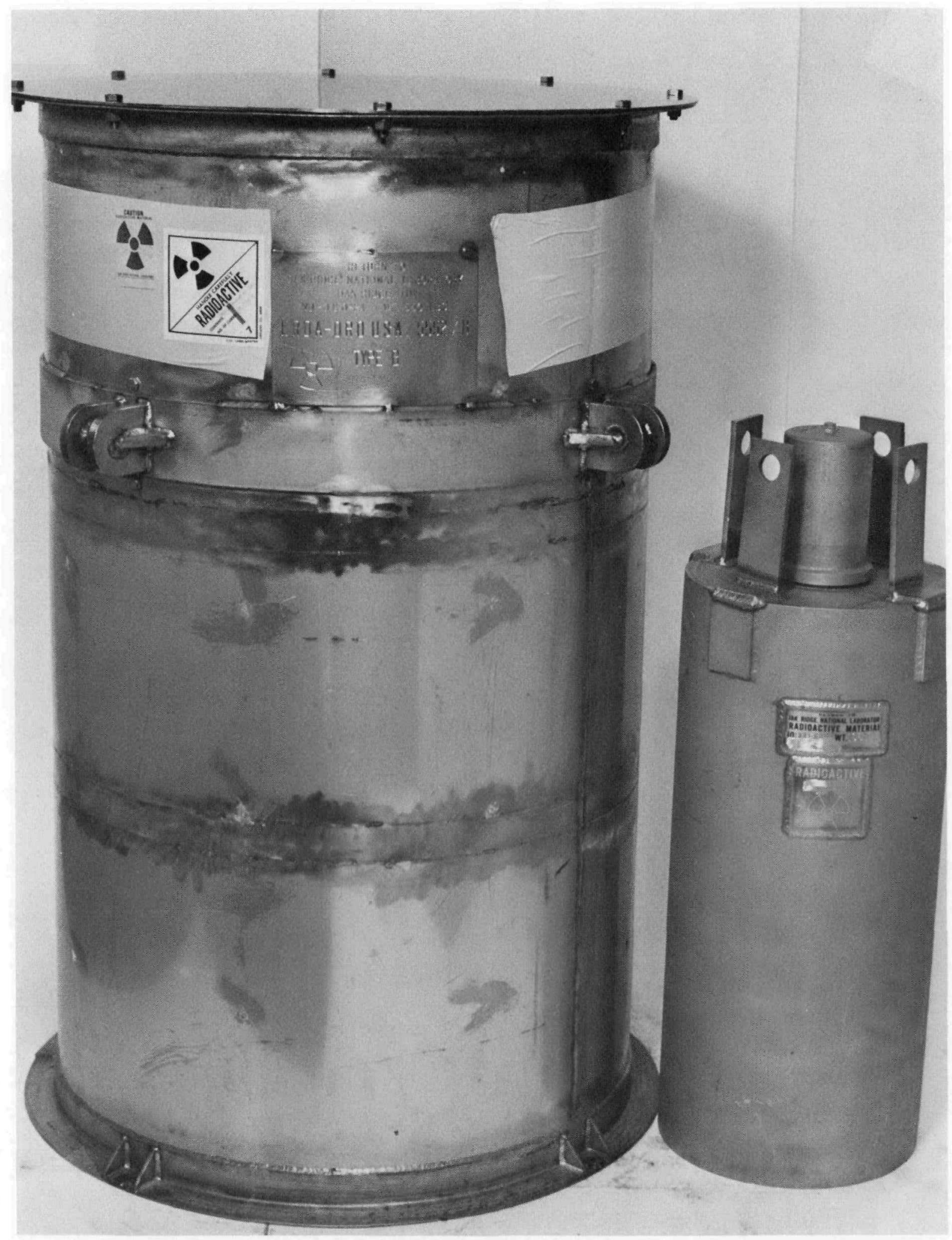

ORNL Gas Package - Type B 


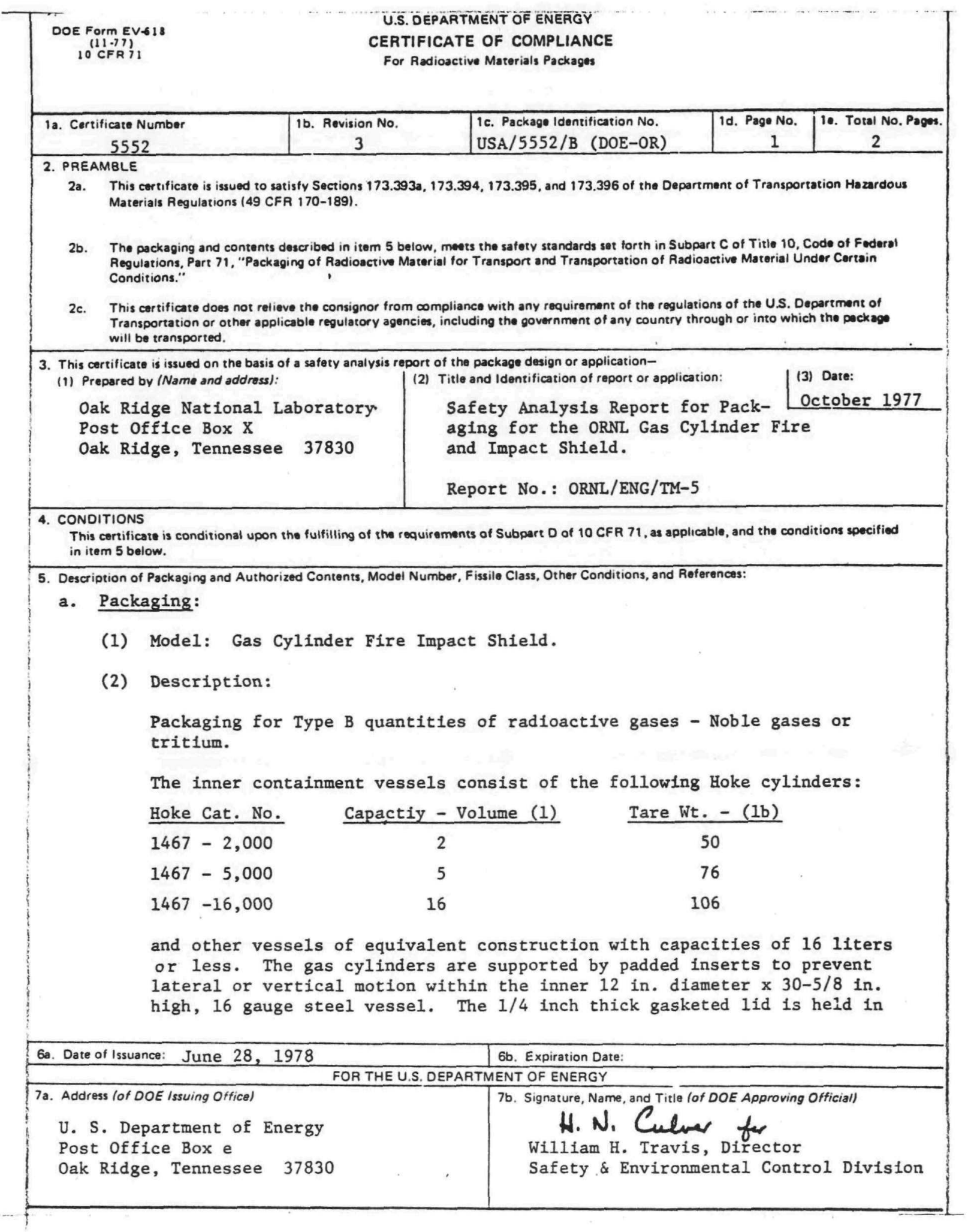


Page 2 - Certificate No. 5552 - Revision 2

12-3/8 in. diameter bolts. Lead, as required, will be positioned inside the inner vessel.

The outer shell consists of a 16 gauge steel, 80 gallon drum with a one-eighth in. thick removable head. The outer drum is two ft. diameter $x$ 41-1/8 in. high. Sealed vent holes are provided in the two types of outer drums. Two types of outer drums are utilized:

(1) The outer drum is mild steel. It utilizes a 12-gauge closure ring with a $3 / 8$ inch diameter bolt and lock nut, or

(ii) The outer drum is $304 \mathrm{~L}$ stainless steel. Its lid is held in place by $8-3 / 8$ inch diameter bolts and nuts and equipped with lock washers.

The space between the inner vessel and outer drum is filled with a high temperature phenolic foam containing glass fibers meeting DOE Specification SP-9. The maximum gross welght of the package is 750 pounds and includes lead shielding.

(3) Drawings

The packagings are as described and fabricated in accordance with Oak Ridge National Laboratory Drawing No. M-11514-EM-001-E.

b. Contents:

(1) Type and Form of Material

Non-fissile radioactive noble gases and tritium.

(2) Maximum quantity of gases not to exceed Type B quantitles of radloactive material consisting of:

Not more than $30,000 \mathrm{C} 1$ of tritium or any noble gases and,

(3) Maximum pressures of gases not to exceed:

(i) Four-fifths atm (11.8 psia) for tritium.

(ii) Five psi (19.7 psia) for other noble gases.

(4) Maximum decay heat load not to exceed five watts. 
II.A.5

A. RADIOACTIVE GASES

SRO-LP 50 FIRE AND IMPACT SHIELD $(50,000 \mathrm{cc})$ 
II.A. 6

ORNL Photo 2416-78

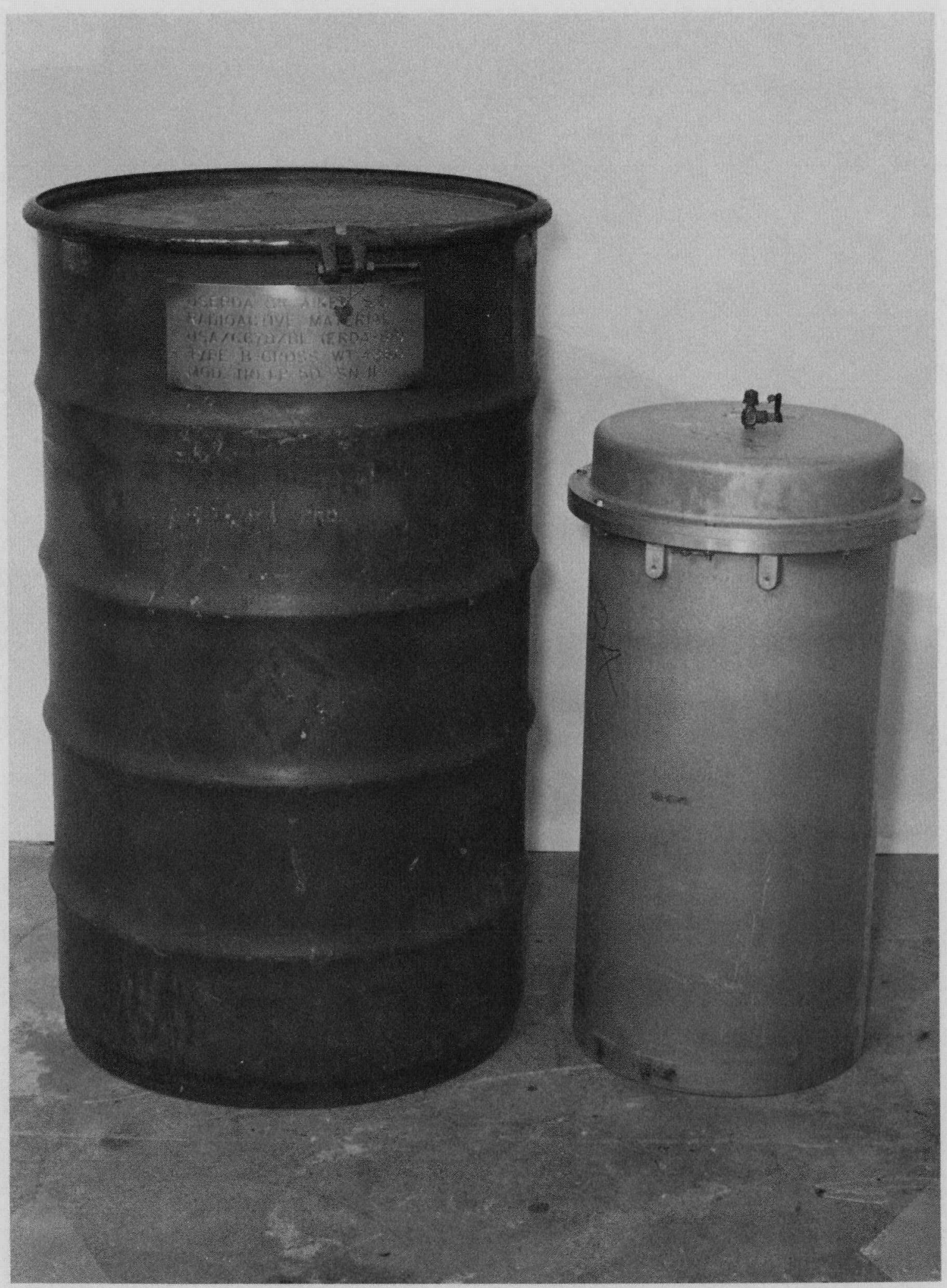

SRO Tritium Shipping Container - Type B 
II.A. 7

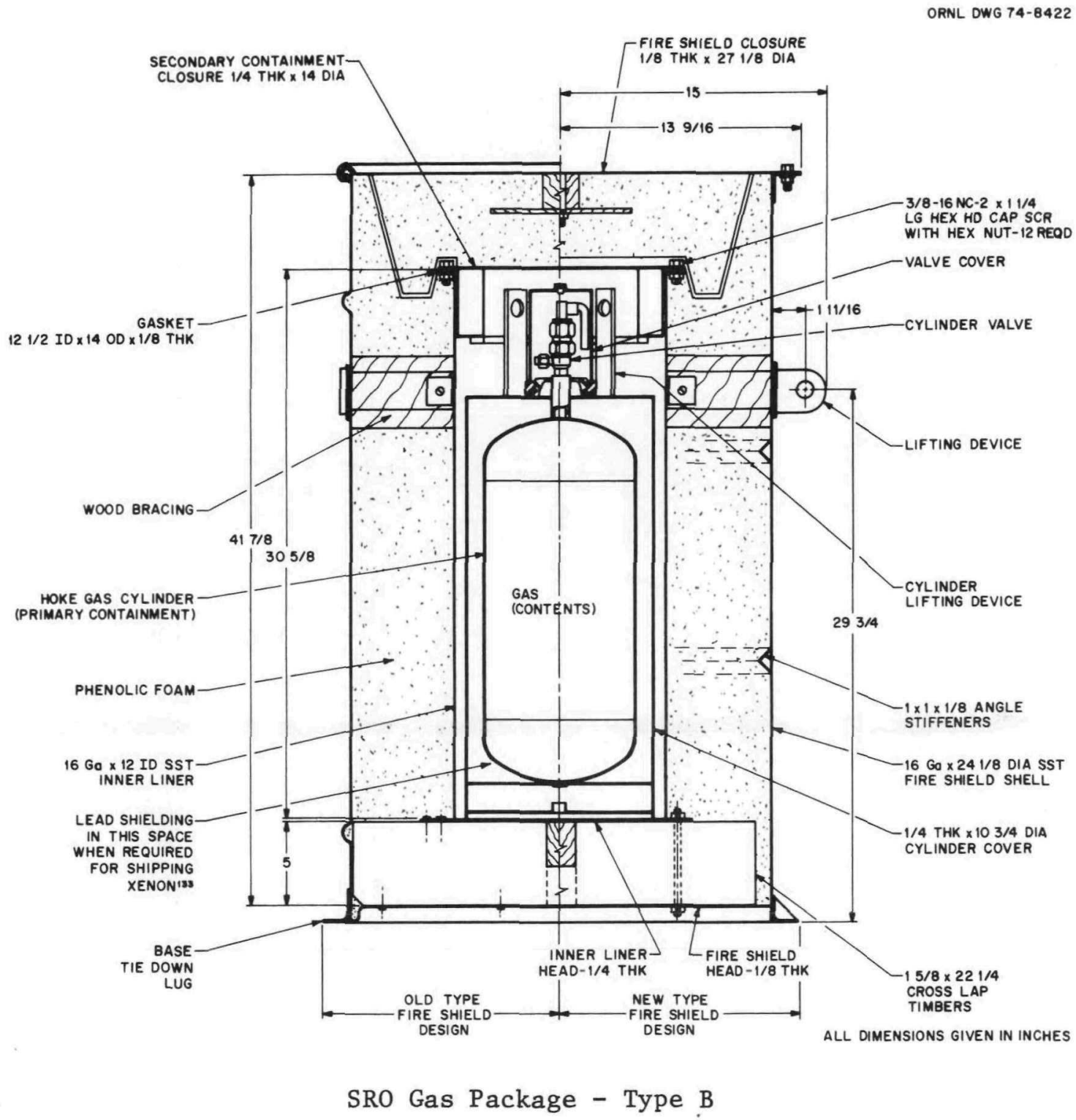




\section{II.A. 8}

ORNL-DWG 78-6199

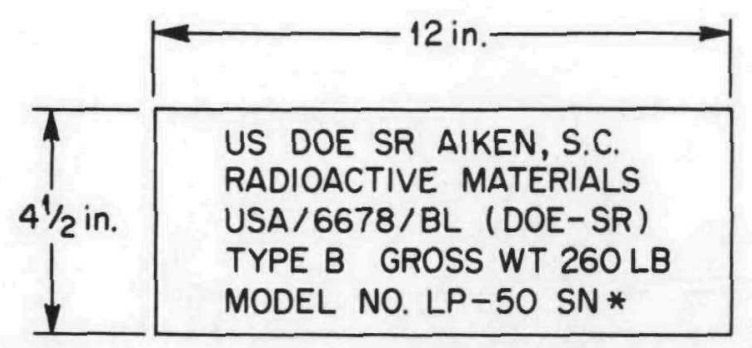

DETAIL A

NOTE: * SERIAL NUMBER AS SPECIFIED ON PURCHASE ORDER

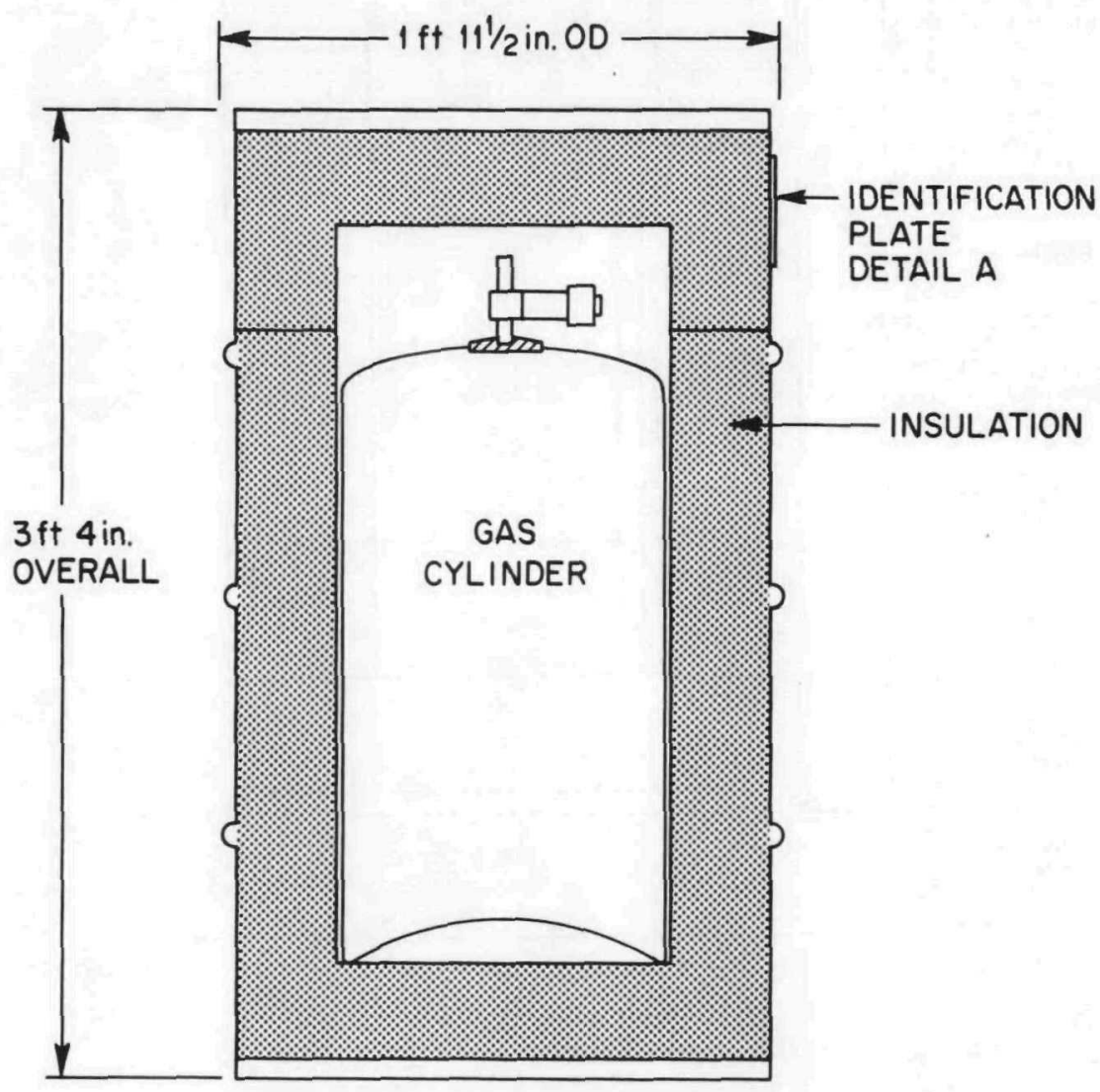

FLAT-TYPE ARRANGEMENT

FIRE AND IMPACT SHIELD FOR LP-50 GAS CYLINDER 
II.A. 9

ORNL- DWG 78-6200
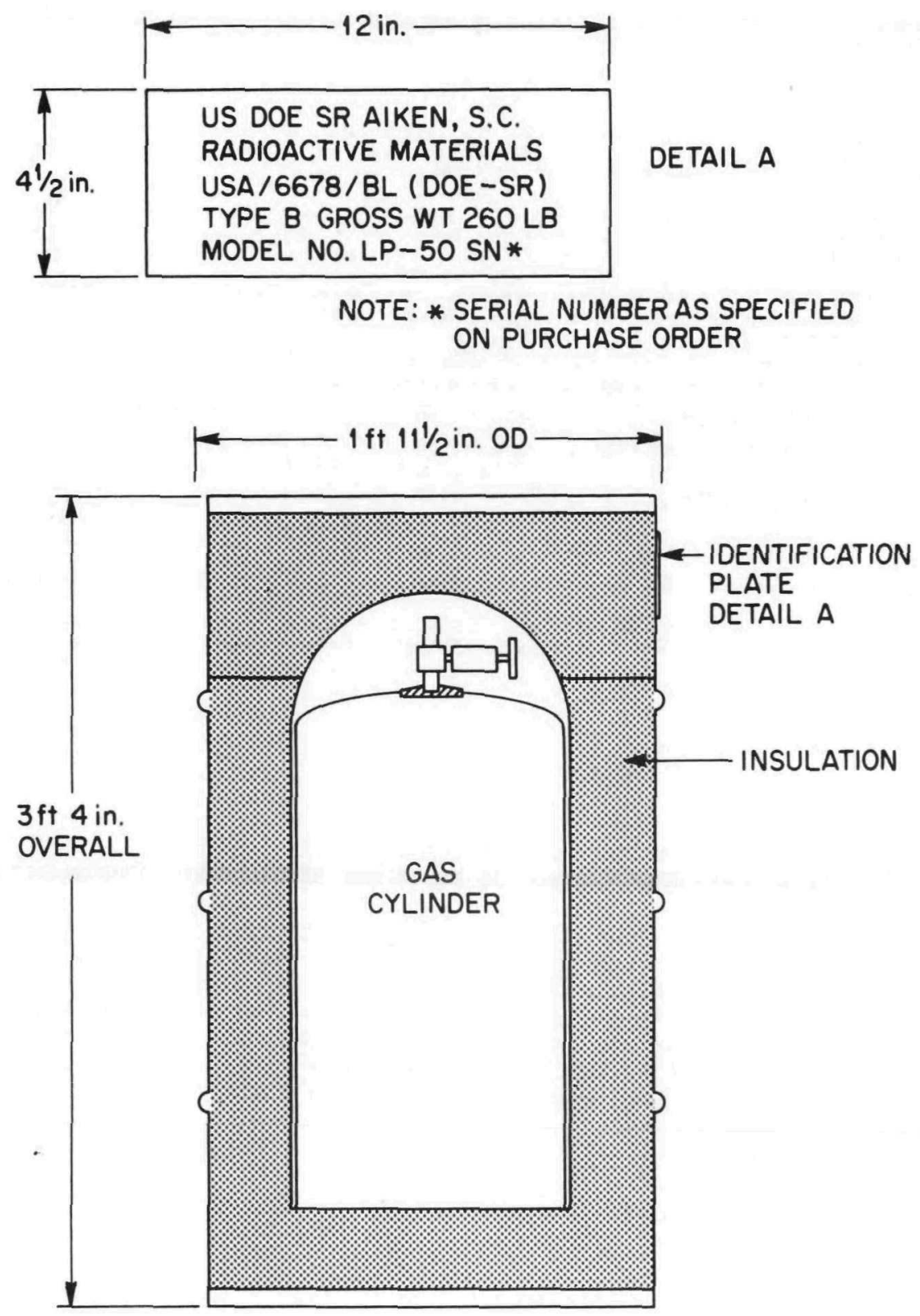

DOME-TYPE ARRANGEMENT

FIRE AND IMPACT SHIELD FOR

LP-50 GAS CYLINDER 
Page 2 - Certificate No. 6678 - Revision No. 0 - Docket No. 71-6678

(b) Contents

(1) Type and form of material

Tritium in mixture with other gases.

(2) Maximum quantity of material per package

Not more than $75,300 \mathrm{~cm}^{3}$ of tritium at STP (1 atm, $25^{\circ} \mathrm{C}$ ), and a maximum activity of 193,500 Curies.

6. The maximum internal fill pressure in the primary containment vessel shail not exceed 24.2 psia at $25^{\circ} \mathrm{C}\left(77^{\circ} \mathrm{F}\right)$.

7

- Acceptance, maintenance and use of the package shall be in accordance with the procedures and requirements of Chapters 6 and 7 of DuPont Report No. DPSPU-74-124-5, April 1975.

8. The leak test described in paragraph 7.1.3 of DuPont Report No. DPSPU-124-5, April 1975 shall be repeated after the third use of each packaging. In addition, a primary containment vessel before use of a packaging for . shipment, shall have been tested in accordance with the above leak test (paragraph 7.1.3, DPSPU-124-5) within the preceeding 12 month period.

8. Expiration date: October 31, 1982.

\section{Reference}

E.I. duPont de Nemours and Company Report No. OPSPU-124-5, April 1975.

FOR THE U.S. NUCLEAR REGULATORY COMMISSION

Clente, The Raval

Charles E. MacDonald, Chief

Transportation Branch

Division Fuel Cycle and

Material Safety

Date:

SEP 291977 
0

-

- 
II.A. 13

A. RADIOACTIVE GASES

KRYPTON-85 SHIPPING CONTAINER 
ORML- OWG $78-14392$

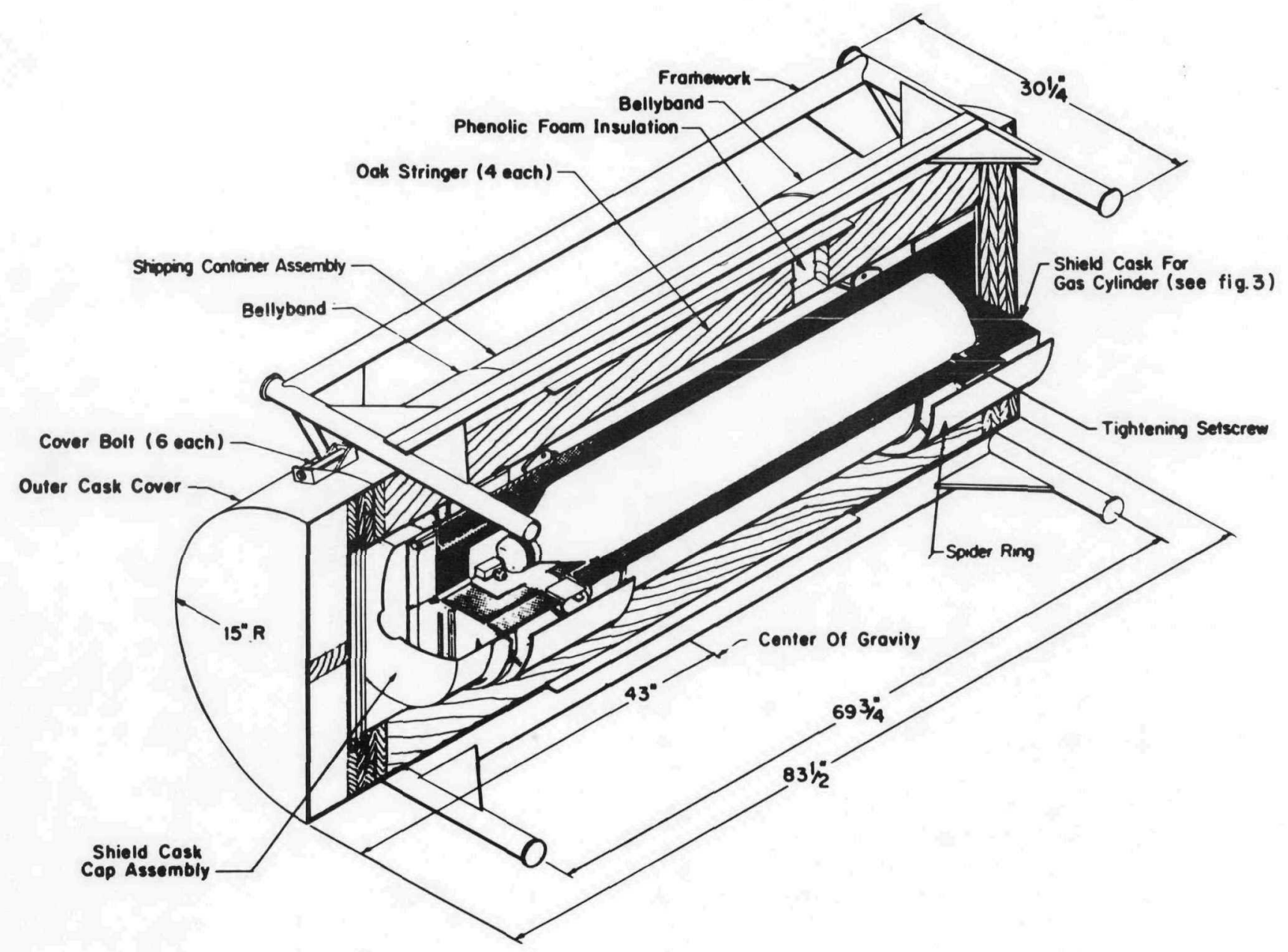

Figure 1 Krypton Shipping Containex 


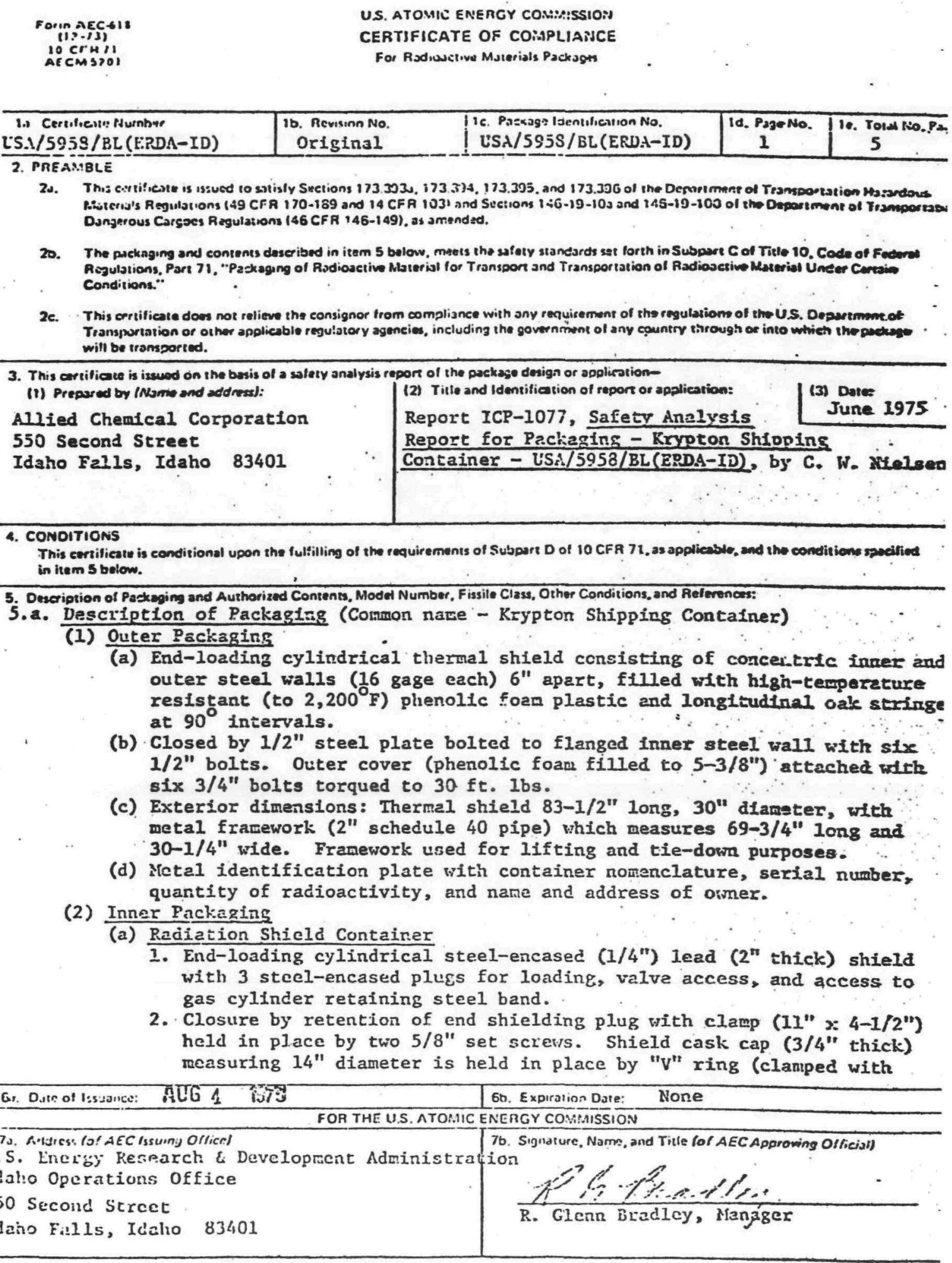


two 5/16" bolts).

(b) Gas Cylinder

1. Primary containment by DOT Specification 3A gas cylinder (length $52^{\prime}$ and outside diaceter of $9^{\prime \prime}$ ) rated to 2015 psig.

2. Equipped with special high temperature monel valve $(: 440 \times 70)$; Kerotest Mfg. Corporation, 2525 Liberty Avenue, Pittsburgh, Pa. 15222. Valve Mieasures $4-5 / 8$ " with a torque of 90 in. Ibs. for closure.

(3) Gross Weight: 5200 lbs.

(4) Sketches of completely assembled container (Figure 1), lead shield and gas cylinder (Figure 2) and special monel valve (Figure 3) are attached.

5.b. Authorized Contents

Gaseous Krypton-85 (Transport Group III) in Large Quantities, not to exceed :

(1) 74,000 Curies

(2) $1000 \mathrm{BTO} / \mathrm{hr}$ decay heat (293 watts)

(3) 500 psig gas cylinder pressure.

5.c. References

(1) A. J. Mallett and S. G. Wheatley, Fissile Material Container and Packagting Development and Testing Program, K-.1661 Union Carbida Corporation, April I, 1966

(2) A. J. Mallett and C. E. Newton, Protective Shipping Packages for 30-Inch Diameter UF Cylinders, $\mathrm{K}-1686$, Union Carbide Corporation, AEC-ORGDP, Apri1 13, 1967

(3) 49 CFR, Parts 170-189, DOT Hazardous Materials Regulations 
II.B.1

B. RADIOACTIVE SOLIDS

$$
\text { DOT-6M }
$$


II.B. 2

ORNL Photo 2539-68

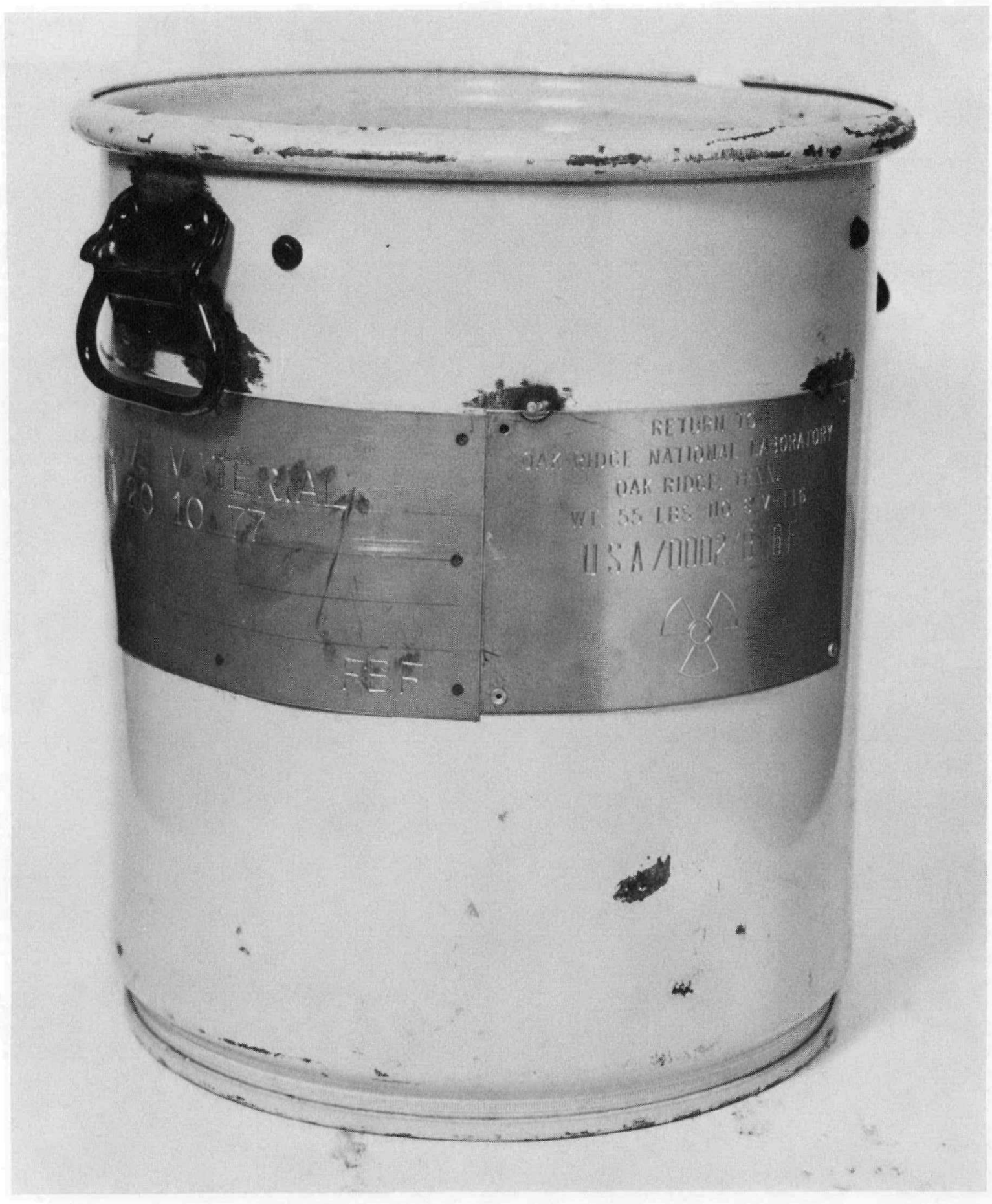

DOT SPEC 6M - Type B Container 
II.B. 3

ORNL- DWG 76-13675R

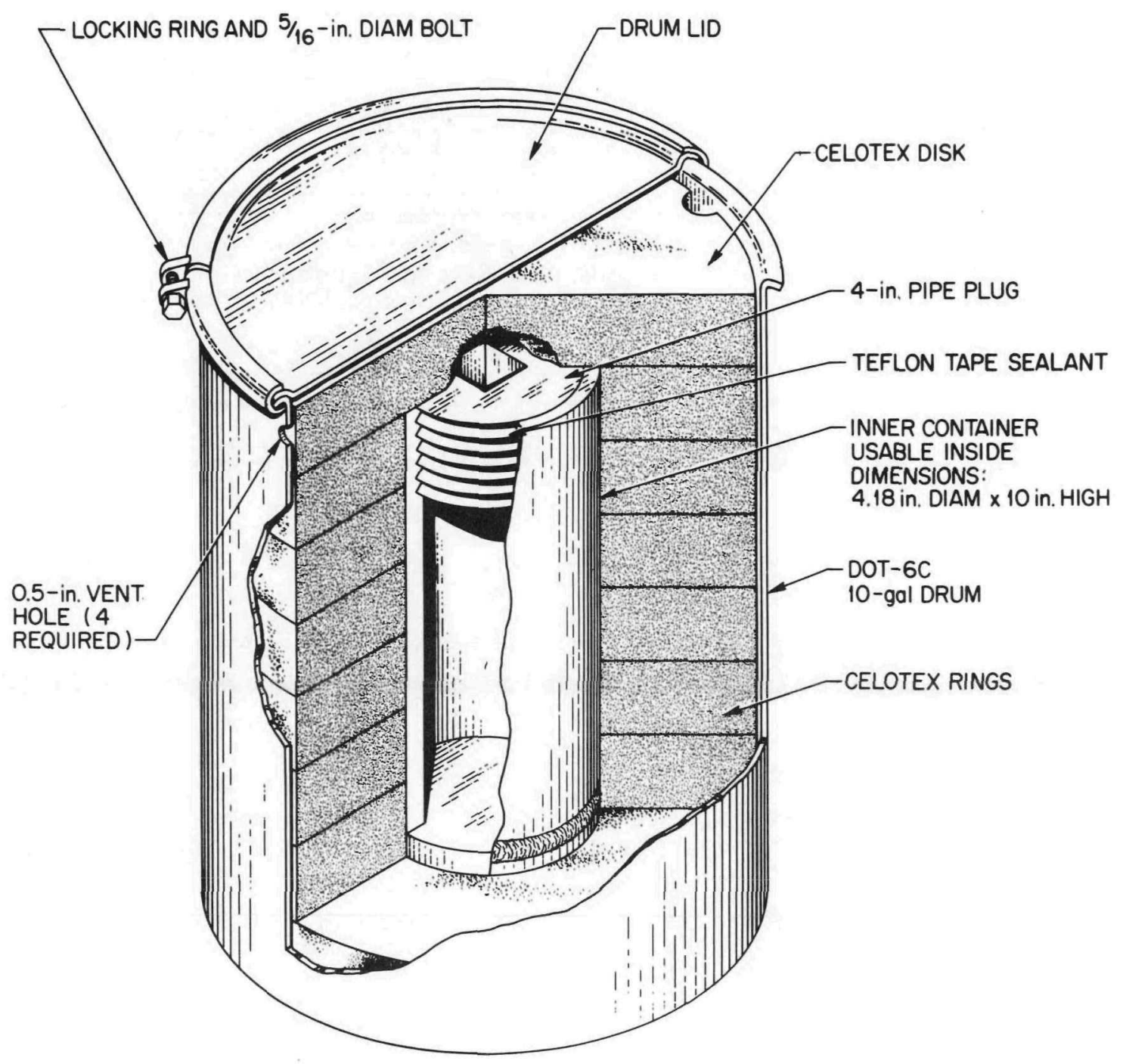

TYPICAL ASSEMBLY DETAIL, 10 gal SIZE DOT-6M

WEIGHT-6O lbs, TYPE B 


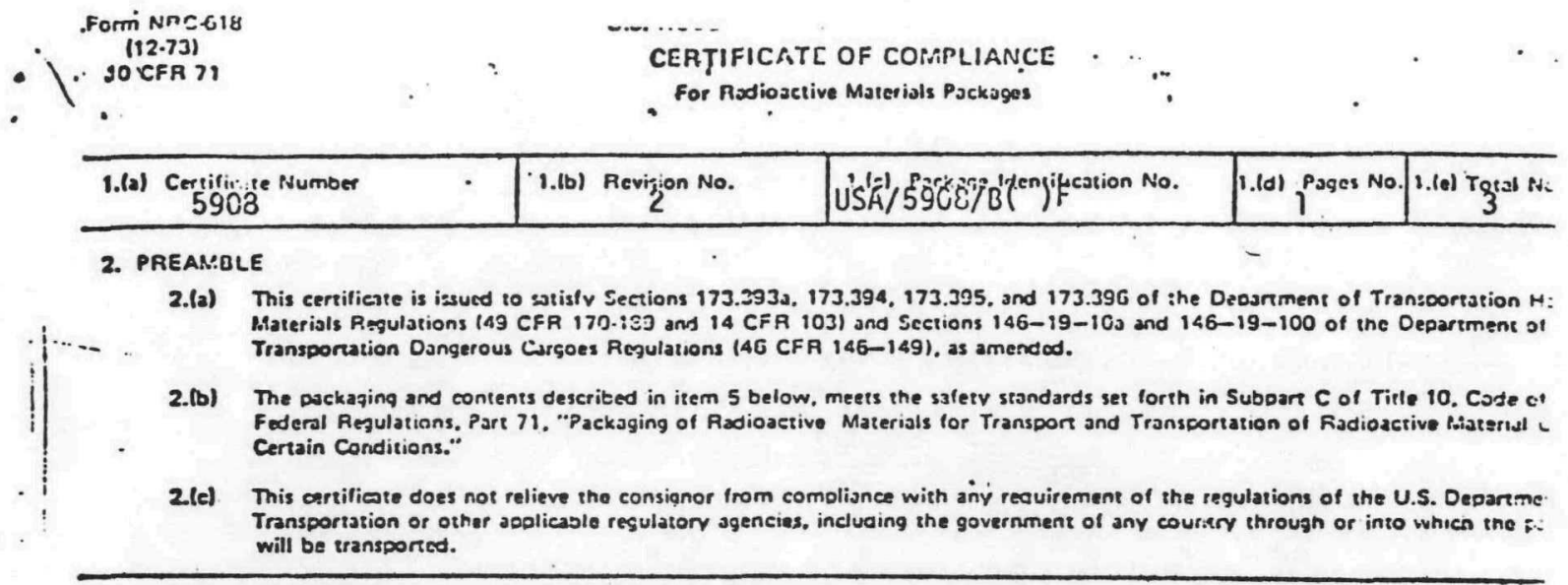

3. This cerrifieze is issued on the basis of a safery analysis report of the package design or applieation-

3.(a) Prepared by (Name and addiess):

The Babcock \& Wilcox Company

609 N. Harren Avenue

Apollo, Pennsylvania 15613

4. CONOITIC::S

3.(b) Title and identificstion of report or apolicstion:

Nuclear Materials and Equipment Corporation epplication dated May 3, 1974, as suppieninented.

This certificte is eonditional upon the fulfilling of the requirements of Subpart D of 10 CFR 71. as asplicable, and the canditions : In irem 5 below.

5. Deseription of Packajing and Authorized Conzents, stodel Number, Fissle Ciass, Other Conditions, and Refertencos:

(a) Packaging

(1) Model No.: DOT-6M Type B

(2) Description

Metal packaging as described and constructed in accordance with DOT Specification 6M (Title 49 \$178.104).

\section{(b) Contents}

(1) Type and form of material

(i) Solid radioactive materials which will not decompose at temperatures up to $250^{\circ} \mathrm{F}$. Carbide compounds are not authorized.

(ii) $\mathrm{UO}_{2}$ or $\mathrm{UO}_{2}-\mathrm{ThO}_{2}$ binary mixtures in the form of powder or compact pellets. The uranium isotopic content is nominally $97 \% \mathrm{U}-233$ with $10 \mathrm{ppm} \mathrm{U-232.}$

(iii) Plutonium nitrate or uranyl nitrate solution in flame sealed glass ampoules or screw top plastic vials, each within one or more additional plastic vials with taped lids, and within a sealed product can or polyethylene bottle containing a sufficient amount of vermiculite to absorb twice the liquid contents present. 
Page 3 - Certificate No. 5908 - Revision No. 2 - Docket No. 71-5903

8. Maximum decay heat per package shall not exceed ten (10) watts.

9. The package authorized by this Certificate of Compliance is hereby approved for use under the general license provisions of Paragraph 71.12(b) of $10 \mathrm{CFR}$ Part 71.

10. Expiration date: February 28, 1981.

\section{REFERENCES}

Nuclear Materials and Equipment Corporation application dated May 3, 1974.

Westinghouse Electric Corporation supplement (WAPD'-RS(CC)-620) dated May 8, 1973 is required for the contents described in $5(b)(1)(i i)$.

Allied Chemical Corporation, Report No. ICP-1061, December 1974 (required for the contents described in 5 (b)(i)(iii) and $5(\mathrm{~b})(2)(\mathrm{iv}))$.

FOR THE U.S. NUCLEAR REGULATORY COMMISSION

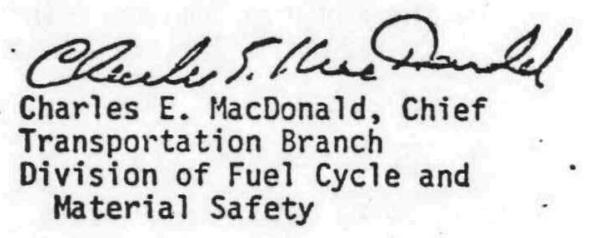

Date: OCT $1 \& 1977$ 
II.B. 7

B. RADIOACTIVE SOLIDS

DOT-20WC-1 
II.B. 8

ORNL Photo 2866-78

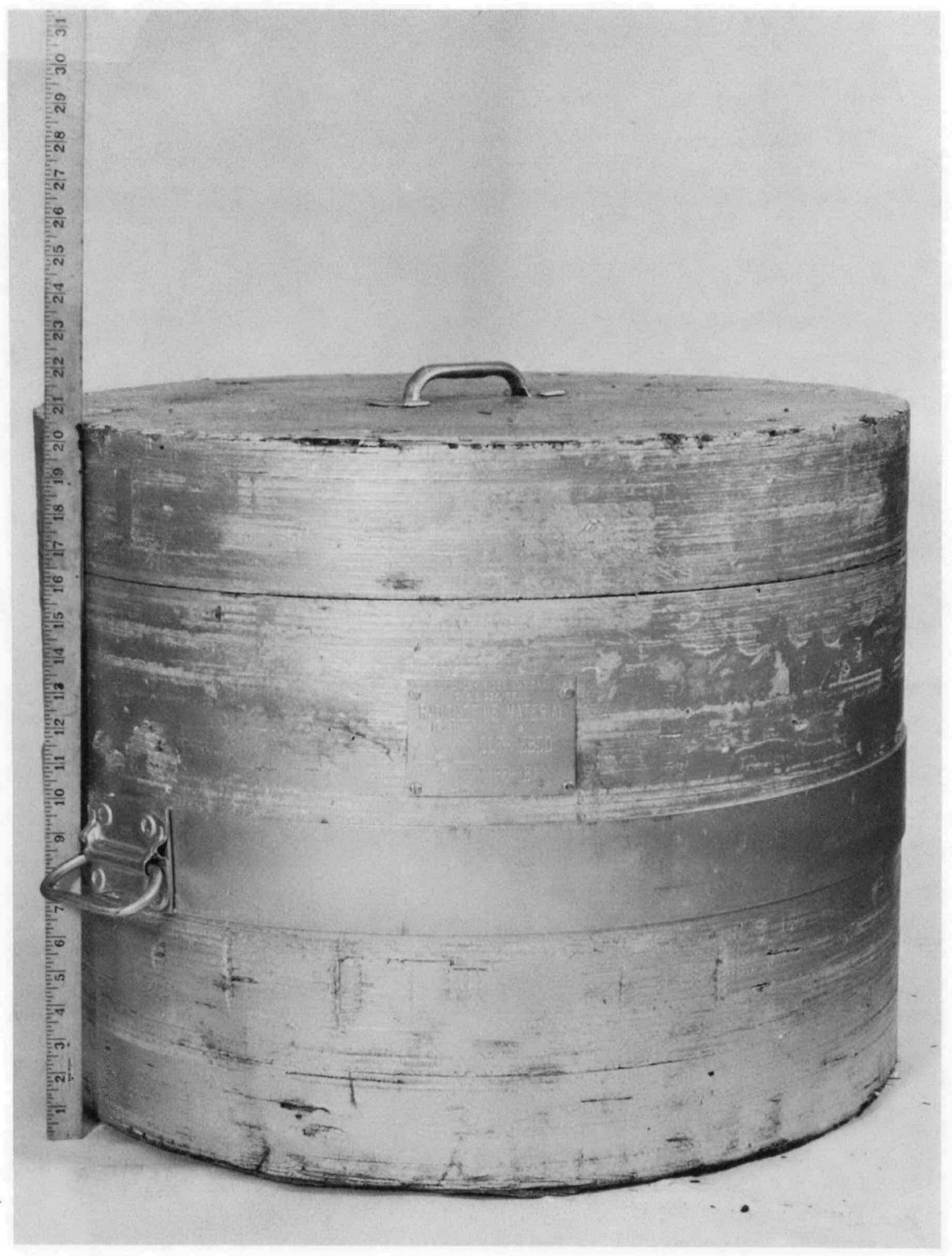

DOT 20WC-1 - Type B Container 
II.B. 9

B. RADIOACTIVE SOLIDS

$$
\text { DOT-20WC-3 }
$$


ORNL Photo 2426-78

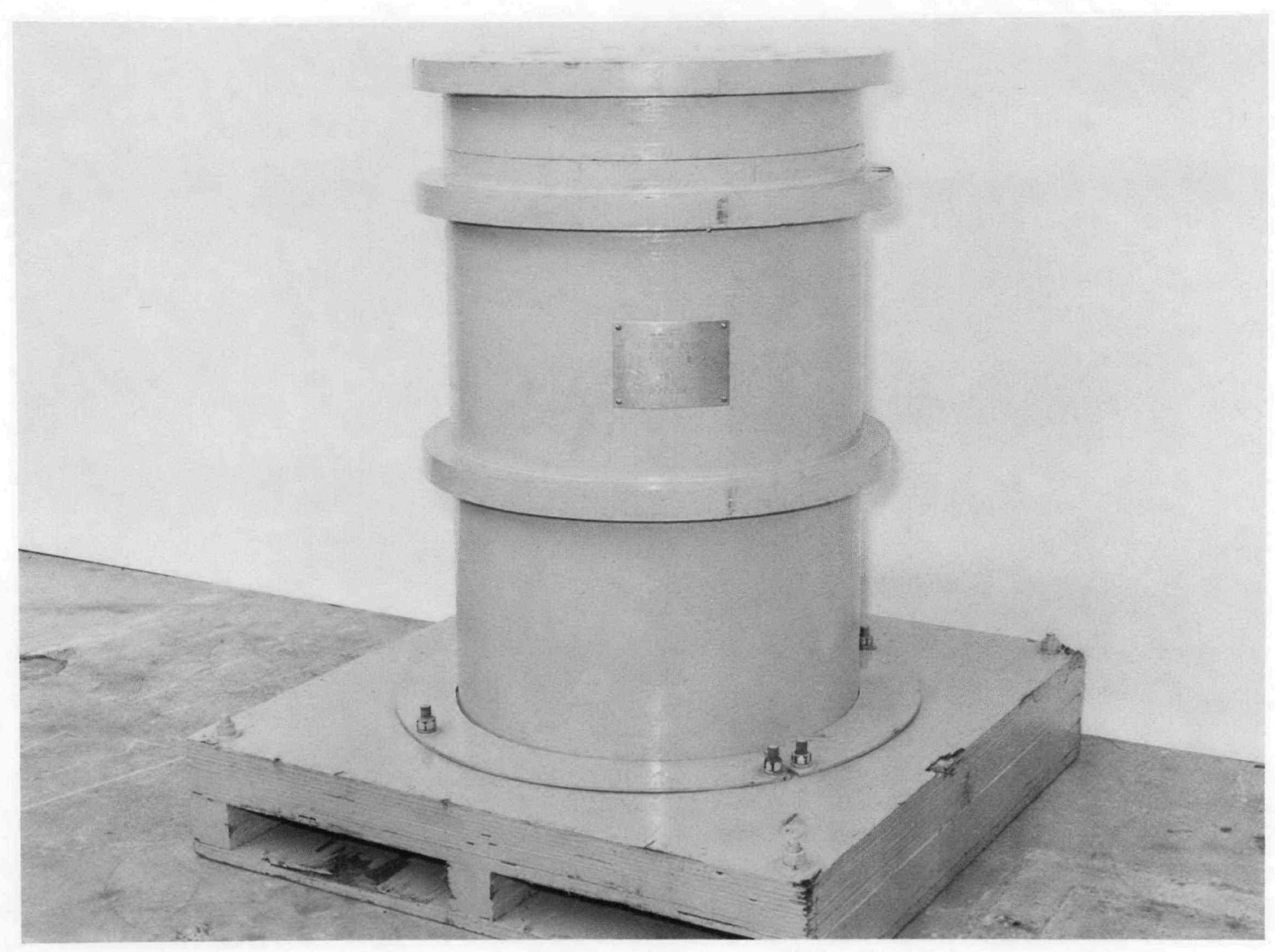

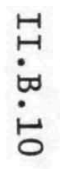

DOT 20WC-3 - Type B Container 
II.B. 11

B. RADIOACTIVE SOLIDS

DOT-20WC-4 
II.B. 12

ORNL Photo 2420-78

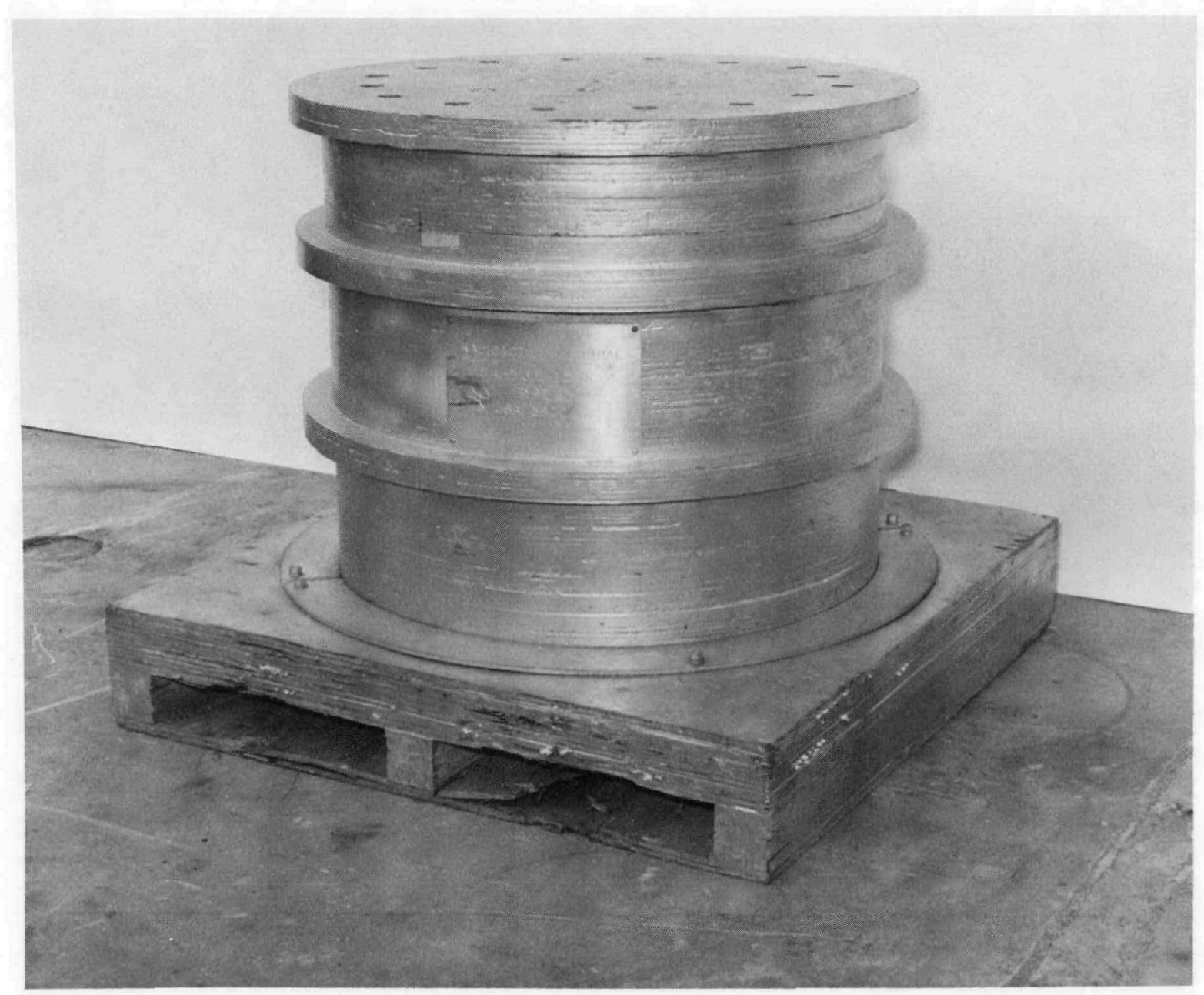

DOT 20WC-4 - Type B Container 
II.B. 13

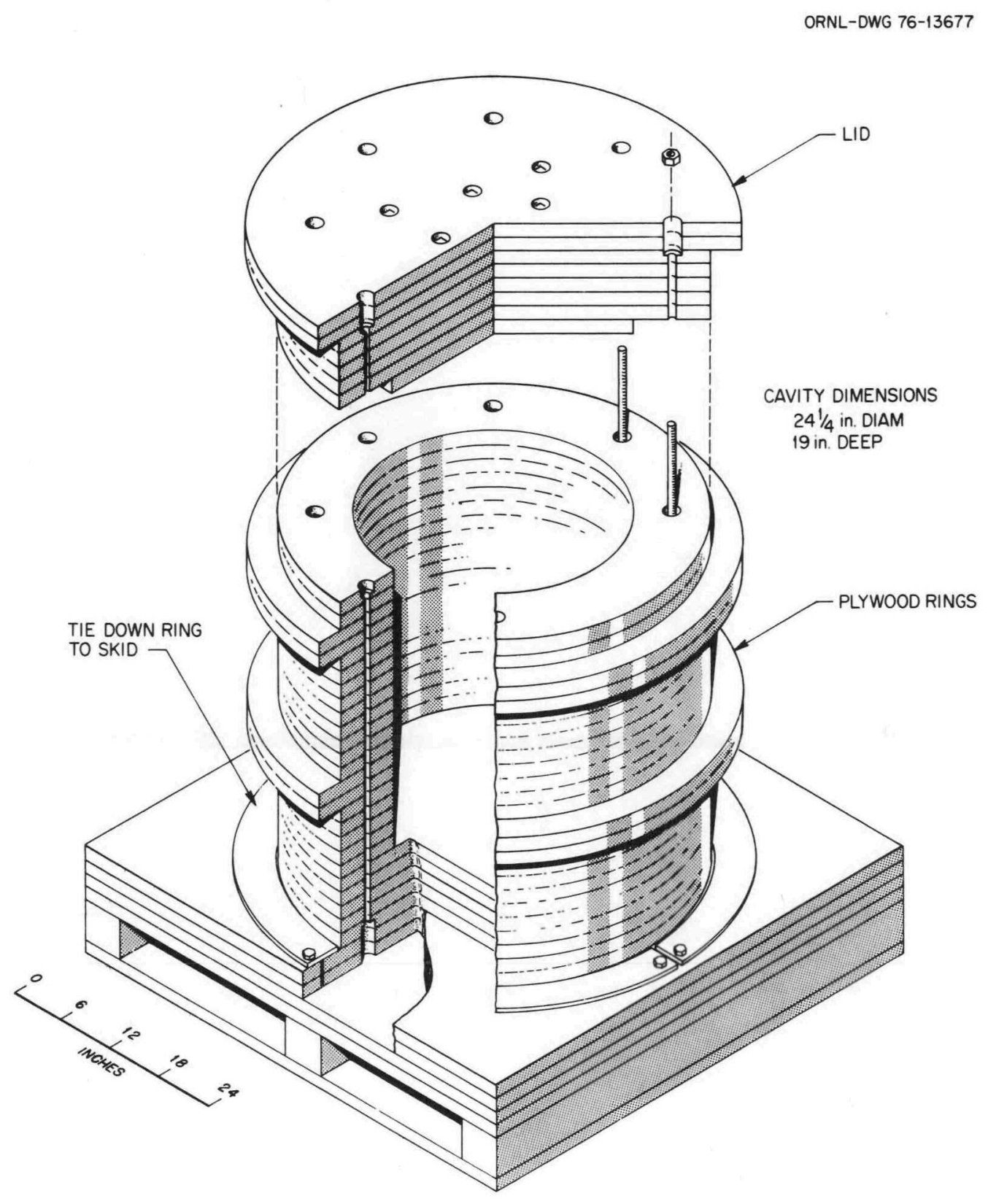

FIRE SHIELD; US DOT-2O WC-4 
-

-

- 
II.B. 15

B. RADIOACTIVE SOLIDS

DOT-20WC-5 
II.B. 16

ORNL Photo 2406-78

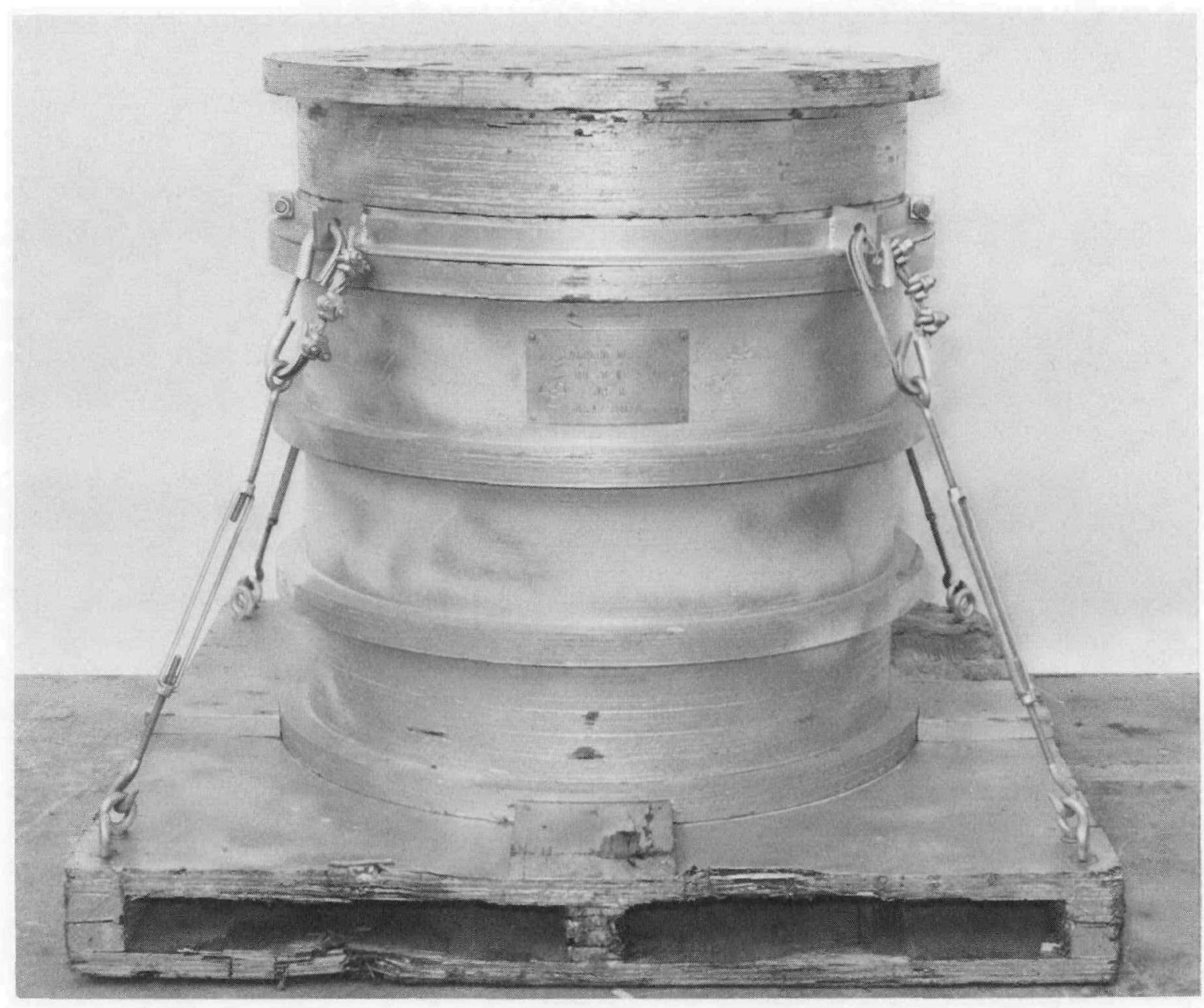

DOT 20WC-5 - Type B Container 


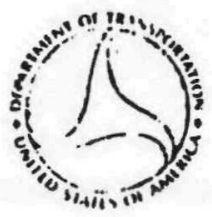

\author{
DEPARTMENT OF TRANSPORTATION \\ HAZARDOUS MATERIALS REGULATIONS BOARD \\ WASHINGTON, D.C. 20590
}

SPECIAL PERMIT NO. 5800

This special permit is issued pursuant to 46 CFR $146.05-4$ of the U. S. Coast Guard (USCG) Dangerous Cargo Regulations and $49 \mathrm{CF} R 170.13$ of the Department of Transportation (DOT) Hazardous Materials Regulations, as amended.

1. The U. S. ATOMIC ENERGY COIMISSION (USAEC) and its contractors and licensees, the DEPARIMENT OF DEPENSE and 1ts contractors, and licensees of "arreement states" as approved by the USAFC, are hereby authorized to ship Type B quantities of any non-fissj.le radioactive material in either normal or special forin, as provided for herein.

2. Each user of this permit must register his identity with this Board prior to his first shipment under the permit.

3. The authorized packaging consists of an interim DOT Spec1fication 20!IC woodon protective jacket, as described in Appendix A hereto, when used with any single one of the following types of inner containment vessels which nust fit snugly within the Jackei:

a. A DOT Specification 55 (or equivalent) metalencased shielded inner containment vessel;

b. A DOT Specification $2 R$ (or equivalent) metal inner containment vessel; or

c. A DOT Specification 7A inner packaging which has a metal outer wall (not authorized for normal form radioactive materials).

4. The packaging design is bascd upon the ambient conditions as prescribed in Marginal C-2.4.3 of the Regulations ror the Safe Transport of Radioactive Materials, 1967 Edition, Intcrnational Atomic Energy Regulation (IAEA).

5. The authorized package meets the criterla of the Internationai Atomic Energy Agency for Type B packaging for radioactive materials.

6. Prior to each shipment authorized by this permit, the shipper shall notify the consignee and, for export shipments, the competint authority of any country into or through which the package vill pass, of the dates of shipment and expected arrival. The shipper shall notify each consignec of any special loading/unloading instructions prior to his first shipment. 
\%. Ihe oulside of eacis frelle : lidsij be plainly and durebly

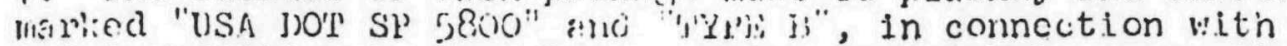

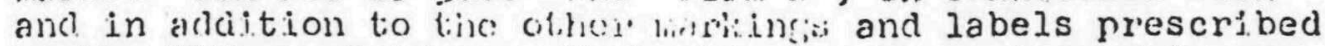

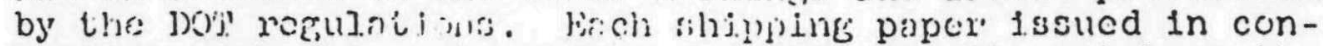

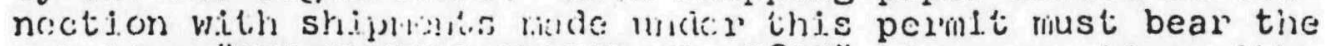

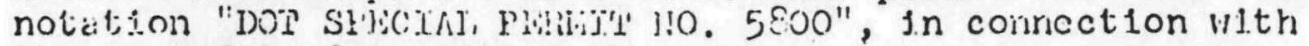
the combdjty descivinion the inon.

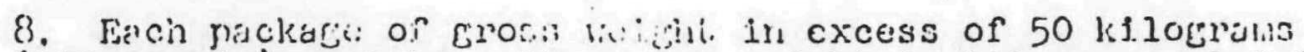
(i10 pouricis) must hove il: (jwes velght in kilograms plain]y and durabjy malked ciim the cillericir. of the package.

9. Shipmonts aro authori:-cii cmly by vasscl, carco-only a1rcrort, passongos-ceisying alrcioft, rail, and motor vehicje.

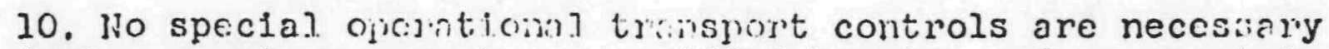
durlng carriage cxecpt is srectsied herein, and no special alrangements have beon mate incior larinal $c-6.5$ or the IAEs Requlations.

11. For shipment:s by water, the shiphes or agent: shall notify the USCG Captain of the Pord in the port area through which the shipment is to be made, of the name of the vessel on which the shipment is to bo mude, and of the time, date, and place of loading. When the initial notification is given in a port arca, it nust be accomininied by a copy of this permit, addressed to the attention of that Capiain of the Port.

12. Any incident involving loss of contents must be promiptiy reported to this Board.

13. This permit does not relieve the shipper or carrier from compliance with any requirenent of the DOT regulations, includIne 46 CFR Paris 116 to 149 or the USCG Regulations, excent as specifically provided for herein, or the regulations of any foreign government into or through which the package will te carried.

14. This permit expires Janury $1 \%, 1971$. 


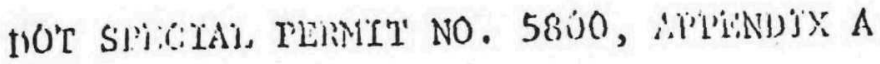

January 1, 1969

Inter:jun Din specificaticn 20\%C

5 178.194 Specification 20 Houden protective jachet

\$ 178.194-1 General requiremints

(a) Each jacket nust mect the applicable requirements of $\mathbf{5} 173.24$ of this chapter.

(b) Maximuin gross veight of the jacket plus the contents may not excced the following:
(1) Spec. 20k:-1: 500 pounds
(2) Spec. 20ric-2: 500 pounds
(3) Spec. 20iric-3: 1000 pounds
(4) Spec. 20ric-4: 2000 pounds
(5) Spec. 2011c-5: 4000 pounds

\section{$\$ 178.194-2$ Materials of construction}

(a) The general configuration of the wooden protective jacket is a hollow cylindrical shell constructed of one-piece discs and rings of plywood or solid hardwood reinfurced with stecl rods.

(b) Plywood must be exterior-grade, void-free, douglas fir (or equivalent) not more than one inch thick. Solid hardyood is authorized for Spec. $20 \%-2$ onl $;$.

(c) Discs and rings must be glued together with a strong, shock-resistant adhesive, such as either of the following:

(1) A resorcinal-formaldehyde adhesive, which has been bonded undar heat and pressure; or

(2) A polyvinyl-acetate emulsion, which has been reinforced with celentcoated nails. The nails must be randomly spaced and must be at 1 east $2-1 / 2$ times as long as the minimun thickness of the plywood discs or rings.

(d) Full-length steel rods are required for reinforcement and lid closure. For Spics. 20\%c-1 and 20wC-2, a mirimum of six rods at least 0.25 inches in diameter are required. For spec. 20w-3, a mininum of 12 rods, at least 0.375 inches in dianeter are required. For spec. 20w- -4 , a minimum of 16 rods at least 0.375 inches in diameter are required, and for spec. 20\%C-5, a minimum of 16 rods at least 0.5 inclies in diameter are required. For spces, $20: \mathrm{ic}-1$ and $20 \%:-2$, steel rods must be equally spaced around the circumference of the rings and discs, midviay between the O.D. and I.D. of the rings. For specs. 20wC:-3 and 20w-4, bolts may be staggered altcrnately in tro rows, at \pm 0.5 inches from ths. 
Iune 11 idway between the 0.11 . and I,b. of the rings. Fur Spec. 20hic-5, bolts mal" he staggereis altriatidy in tr:o rovis at \pm one inch from the line miclvisy between tlir $(1,1)$. and I.T). of the rings. Rod encls must be threacied and sccured with lock nuts and stecl washers, or equivalent davjce, te provide at. leasit a one inch dithetcr bearing surface on cact. curl. Ends of the rols r.ul:t terminate 0.75 inches below the sur:ace of the plywood for specs. 20:0--1 and 20ic-2. For specs. 20wc-3, 20wC-4, arit $20 \mathrm{ric}-5$, the ends of the rods must terfilinat:c 1.5 inches below the surface of the plywood, and thit nortion of cich cnd disc which extends bcyourl the rod ends must be further held in place with lag screws at least four inches long.

(e) 'silicknest of wueden shell:

(1) Spec. 201:0.1: P.t lcast four inchus thick.

(2) Spec. 2u:-2: At lacst linres inches thick. The jacket. must be complotely, ricised by a stecl shell at least 18-gauge thickness, sucil z: , spec. 1711 stecl drum. The steel shell must be verited by at len.t four 0.25 inch diaricter holes, which must be covercd with a iulcible weathcrpruof tape.

(3) Spec. 20h-3: At least five inches thick for the jacket wall, and at least six inchis tliick for the end discs. In additior., at least threc ply:ood clijncs, two inches wide and protrucling two inches beyond the outer surfaces, must be located at each end and midway along the lenglil: of lice jacket,

(4) Spec. $20,0-4$ : At lcast six inches thick for the jacket wall, and at lesst six inches thick for tho end discs. In addition, at least three plywood chines, two inches wide and protruding tro irches bieyond the outer surfictir, must: bo located at each end and midway along the length of the jacket.

(5) Spec. 20rs-5: At least six inchos thick for the jacket wull, and at least cight inches thick for the end discs. In addition, at least five plywood chincs, two inches wide and protruding two inches boyond the outer surfaces, must be located at each end and equally spaced along the length of the jacket.

(f) Figures 1 and 2 illustrate representaive designs.

\$ 178,194-3 Closura

(a) Closure for the wooden protective jacket is provided by the stecl reinforcing rods. The end cup (lid) must fit tightly to th: $b=d_{j}$ of the jacket to prevort a heat pain to the inside of the ja:ket. Tile lid joint for Specs. 20WC-3, 20:C-6, and 20wC-5 may not be co-planar with the end of the inner contairment vessel. 
(b) Spec, 20wc-2. Locking ring closure, if usced, must co:sform to § 178.104-4. Flanged closure, if used, must have at least eight staci bolts (at least 0.25 inci diancter) and lock nuts for equivalcut dovice), spaced not more than five inches betwen centers.

\section{\$ $178.194-4$ Tests}

(a) Each jacket muct be visually inspected for defects such as improper bonding, crackim, crizozion of stecl rods, an improperly fitting closure lid, or other numufacturilig dufects. Particular attention must be given to any separation of the plywool discs and rings which would proyjdc a heat path to the inside of the jacket.

\section{\$ 178.194-5 Painting}

(a) Each jacket must. be co!tpletely painted with a high quality exterior weather resistant paint.

S $17 \% .39 .1-6$ Marking

(a) Each jacket Iutsi be marked on tho external surface as follo;s: "USA DO' 2OWC-( ) PYPE B" and "RADIOACPIVL MATERIAL". The apprecpriate nuneral must be inserted in the markir.g to indicate the appropriate Spec. 20W category; e.g., "USA DOT 2OWC-2". 
-

-

- 
II.B. 23

B. RADIOACTIVE SOLIDS

$$
\text { DOT-21WC }
$$


II.B. 24

ORNL Photo 88461

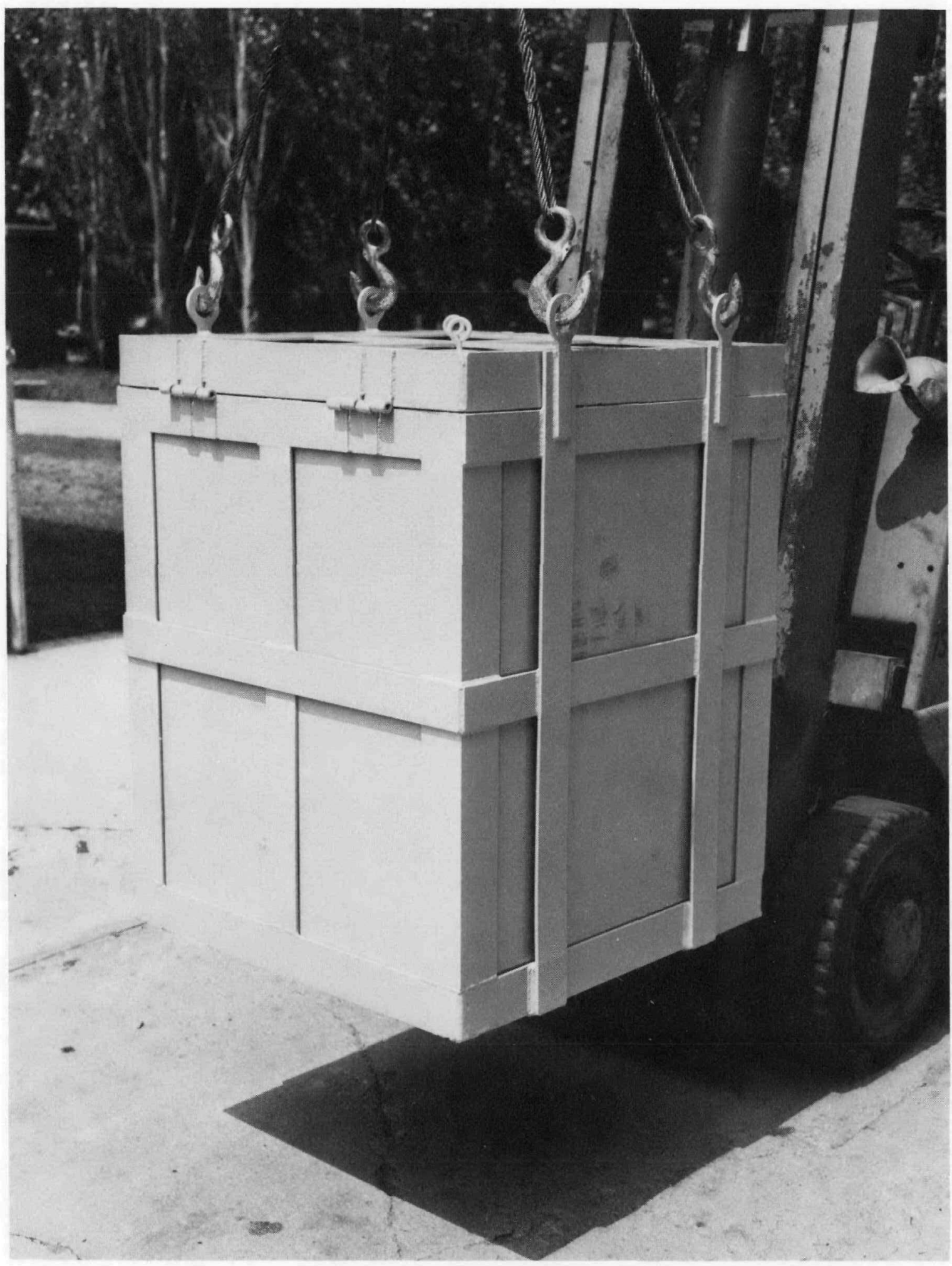

DOT 21WC - Type B Container 


\section{II.B. 25}

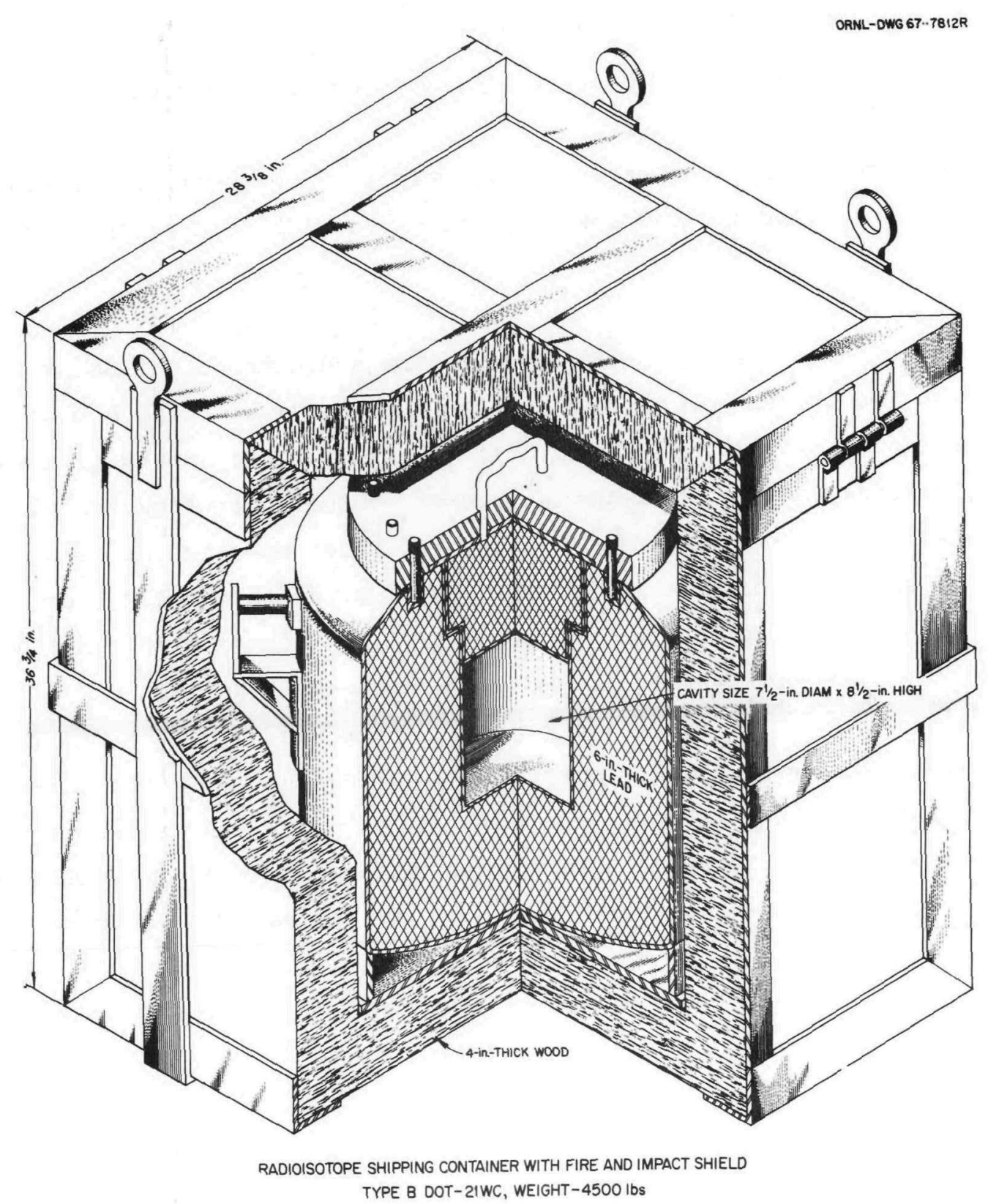




\section{USA DOT SPEC $21 \mathrm{WC}$}

§ 178.195 SPECIFICATION 21WC; wooden-steel protective overpack.

$\S 178.195-1$ General requirements.

(a) Each jacket must meet all the applicable requirements of $\S 173.24$ and this subchapter.

(b) The maximum authorized gross weight of the overpack, including its inner container and contents may not exceed 1360 kilograms (3000 pounds).

§ 168.195-2 Materials of construction and other requirements.

(a) The general configuration of the protective overpack must be a combination of two nested p1ywood boxes, each 2.5 centimeters ( 1 inch) thick, nested within a third wooden box of nominal 5 centimeters (2 inch) thickness solid hardwood. The three nested boxes must be enclosed within a welded framework constructed of mild steel strap, nominally 1 centimeter (3/8-inch) thick by 8-10 centimeters (3-4 inches) wide. A11 outer surfaces of each box must be coated with intumescent paint.

(b) P1ywood must be exterior-grade, void-free, Douglass fir, or equivalent, at least 2.5 centimeters ( 1 inch) thick. Solid hardwood must be maple, or equivalent.

(c) All box joints and interior surfaces must be glued with a strong, shock-resistant adhesive such as polyvinyl-acetate emulsion, or equivalent.

(d) All hardwood joints must be mitered, or equivalent, reinforced with No. 10 cement-coated nails spaced on nominal 15 centimeters (6 inch) centers.

(e) All plywood joints must be butt-type, or equivalent, reinforced with No. 10 cement-coated nails spaced on nominal 15 centimeters ( 6 inch) centers.

(f) The angles and strapping of the metal frame must be spaced such that separation distances do not exceed 15 centimeters ( 6 inches). 
(g) The lid must be of the same material as the box and fabricated in such a manner that closure forms a mitered joint with the hardwood box and 2 stepped-joints with the plywood boxes.

$\S$ 178.195-3 Closure. Closure for the protective overpack must be provided by at least 4 mild steel hinges formed from minimum 2.5 centimeter ( 1 inch) x 5 millimeter (3/16-inch) bar stock. Hinge pins must be minimum 6 millimeter ( $1 / 4-i n c h)$ diameter by 13.3 centimeters ( 5 1/4-inches) long mild steel rod drilled at both ends for cotter pins.

$\S$ 178.195-4 Tests. Prior to each use, each overpack must be visually inspected for defects such as wood checking or splintering, weld cracking, corrosion of steel parts, improper joint bonding, or improperly fitting closure lid.

§ 178.195-5 Required marking. (a) Marking must be as prescribed in $\S 178.24$ of this subchapter.

(b) Marking on the outside of each overpack must include the following:

(1) "USA-DOT 21WC" and "TYPE B" as appropriate.

§ 178.195-6 Typical assembly detail.

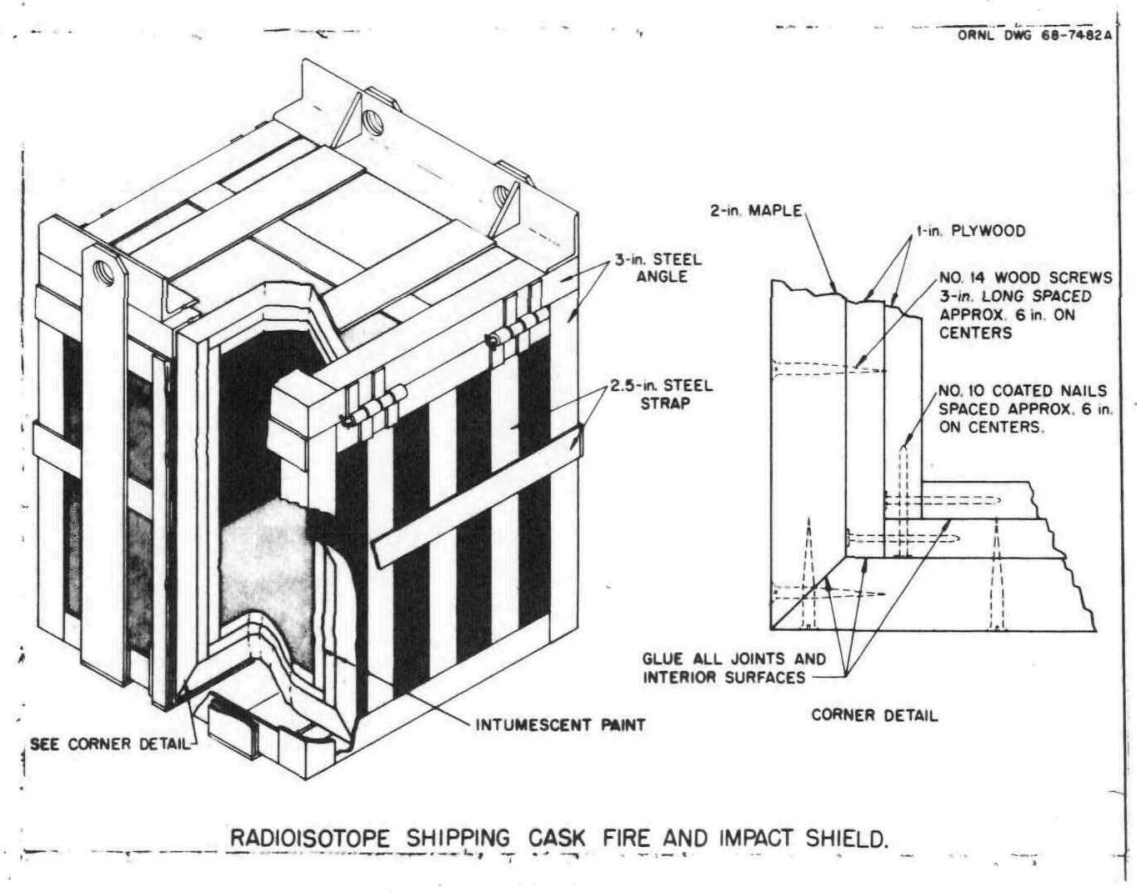


○

○

0 


$$
\text { II.B. } 29
$$

B. RADIOACTIVE SOLIDS

LIOH FIRE AND IMPACT SHIELD 
II.B. 30

ORNL Photo 2868-78

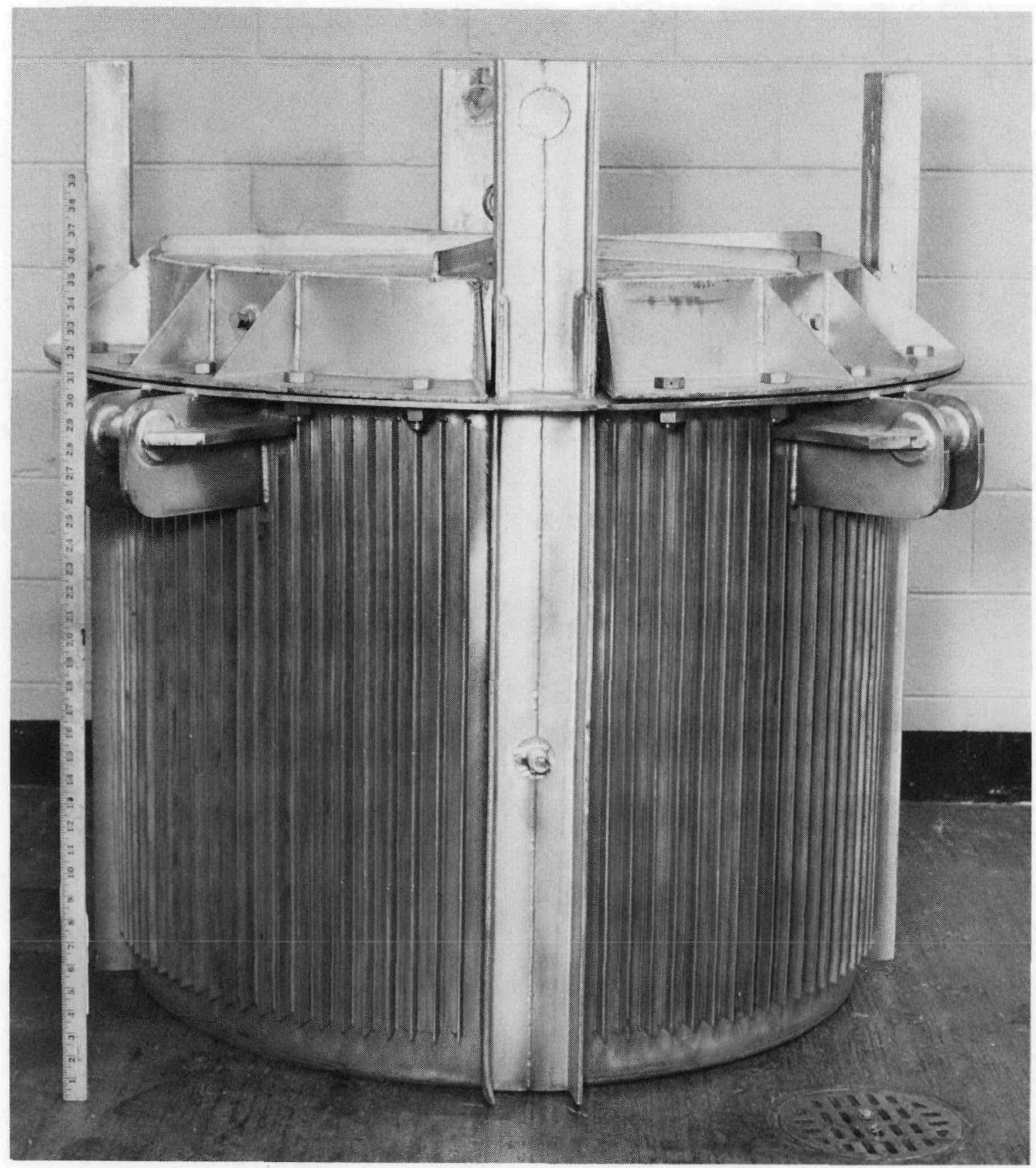

ORNL LiOH Fire and Impact Shield

Type B Container 
II.B. 31

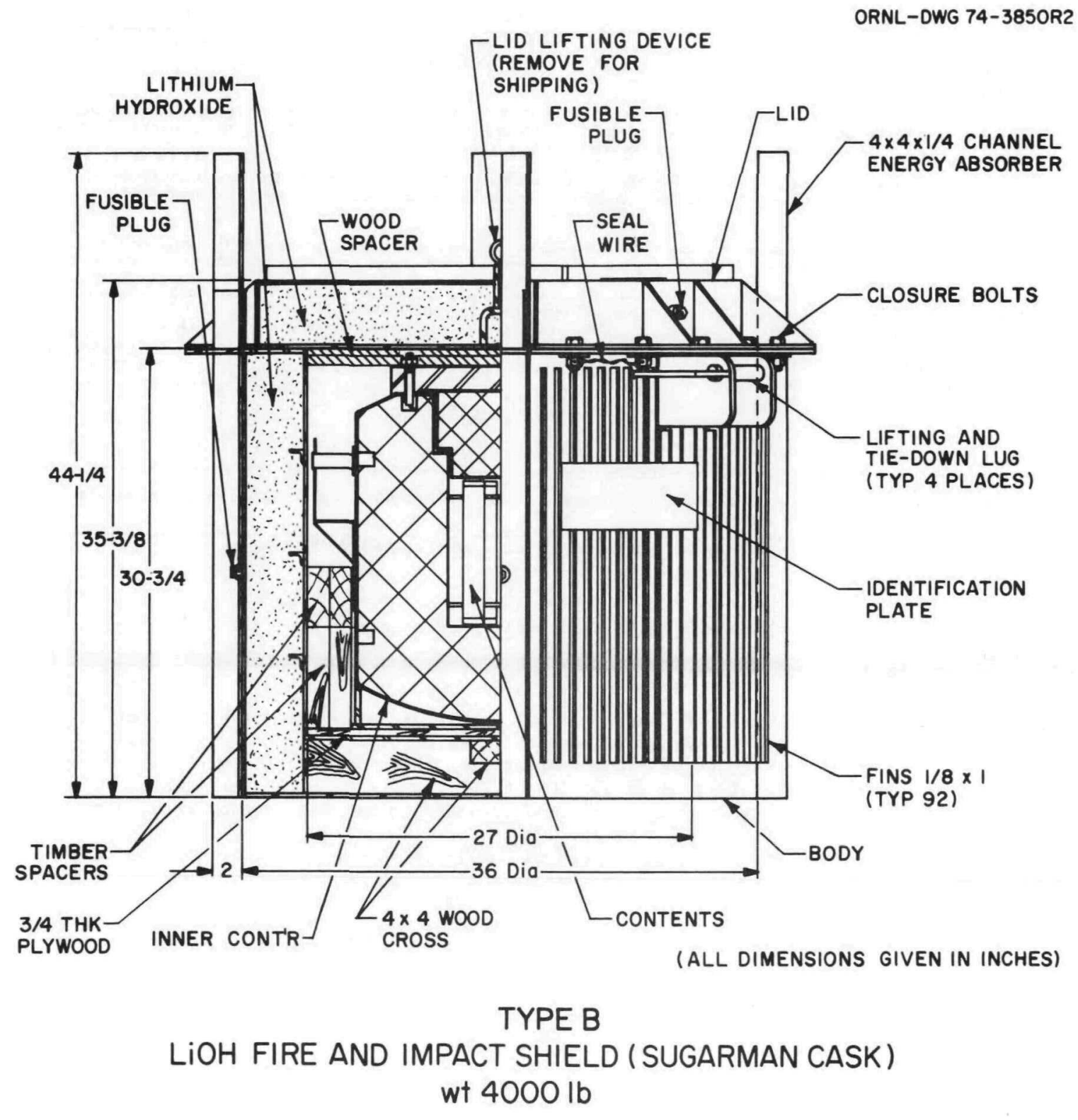




\begin{tabular}{|c|c|}
\hline 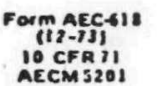 & $\begin{array}{l}\text { US. ATOMIC ENERGY COMMISSION } \\
\text { CERTIFICATE OF COMPLIANCE } \\
\text { For Radioactive Moteridils Padtoges }\end{array}$ \\
\hline
\end{tabular}

\begin{tabular}{|c|c|c|c|c|}
\hline $\begin{array}{l}\text { 12. Certificate Number } \\
\text { USA/9851/BLF (ERDA-ORO) }\end{array}$ & $\begin{array}{l}\text { 1b. Revision No. } \\
0\end{array}$ & $\begin{array}{l}\text { 1c. Package Idennitication No. } \\
\text { USA/9851//BLF (ERDA-ORO) }\end{array}$ & $\left\{\begin{array}{c}\text { 1d. Page No. } \\
1\end{array}\right.$ & 16. Total No. Pages. \\
\hline
\end{tabular}

2. Pheamble

20. This certificate is issued to satisfy Sections 173.393, 173.394, 173.395, and 173.396 of the Department of Transportation Hazardous Materiahs Fegulations (49 CFR 170-189 and 14 CFR 103) and Sections 146-19-10a and 146-19-100 of the Department of Transportation Dongerous Cargoes Regulations (46 CFR 146-149), as amended.

2b. The packaging and contents described in item 5 below, meets the safoty standercts set forth in Subpart $\mathrm{C}$ of Title 10, Code of Federal Aegubations, Part 71, "Packaging of Radioactive Material for Transport and Transportation of Radioective Material Under Certain Conditions."

:

2c. This certificate does not reliewe the consignor from compliance with any requirement of the regulations of the US. Depertment of Trameportation or other applieable repuletory apencies, including the povernment of any country through of into which the package will be wraneported.

3. This certificate is iseved on the basis of a saferty analyis report of the peckage detigh or application

\begin{tabular}{l|l} 
(1) Prepared by (Nome and eddreat: & (2) Title and Identification of report or application:
\end{tabular}

Oak R1dge National Laboratory

Post Offlce Box $X$

Oak Ridge, IN 37830

Safety Analysis Report for

(3) Dato:

November 1977

Packaging for the ORNL Lithlum Hydroxide Fire and Impact Shield

Report No.: ORNL/ENG/TM-8

\section{CONDITIONS}

This certilicate is conditional upon the fulfilling of the requirements of Subpert D of 10 CFR 71, as applieable, and the conditions specified in item 5 betow.

5. Description of Packaging and Autharized Contents, Model Number, Fiasile Class, Other Conditions, and feferences:

(a) Packaging:

(1) Model: Ithium Hydroxide Fire and Impact Shield

(2) Description:

Packaging for Inner Type A and DOT Specification 55 packages to permit transport of Type $B$ and large quantities of radioactive materials and limited quantities of fissile materials, which ara contained within Inner special form encapsulation or DOT Specification $2 R$ containers. The inner vessels will be blocked to minimize movement during transport.

The inner cavity of the shield is a cylinder 27 in. diameter $\times 26$ in. high. The outer shell is $36 \mathrm{in}$. diameter $\times 303 / 4 \mathrm{ln}$. high.

The 1id is $45 / 8^{\circ} \mathrm{in}$. thick. The shield is fabricated from $1 / 8 \mathrm{in}$. thick 304-L stainless steel with the $41 / 4 \mathrm{In}$. nominal space between inner and outer claddins being filled with $\mathrm{L}_{10 \mathrm{H}} \mathrm{H}_{2} \mathrm{O}$ crystals. The outer surface of the shield has 92 vertical cooling fins. The flanged closure is held In posftion by twenty one-inch alloy t teel bolts.

The gross weight of the package is 4,000 1bs.

\begin{tabular}{|c|c|}
\hline 6a. Date of issuance: September 2, 1977 & 6b. Expiration Date: \\
\hline \multicolumn{2}{|c|}{ FOR THE US. ATOMIC ENERGY COMMISSION } \\
\hline $\begin{array}{l}\text { 7a. Address of Issuing Office: } \\
\text { U. S. Energy Research \& Development Adm. } \\
\text { Post Office Box E } \\
\text { Oak Ridge, Tennessee } 37830\end{array}$ & $\begin{array}{l}\text { Will am H. Travis, Diféctor } \\
\text { Safety and Environmental Control Div. }\end{array}$ \\
\hline
\end{tabular}


II.B. 33

Page 2 - Cert1ficate of Compliance, No, USA/9851/BL (ERDA-ORO), Rev. 0

(3) Drawings:

The overpack is described and fabricated in accordance with Union Carbide Corporation, Nuclear Division, Oak Ridge National Laboratory drawings:

$D-R D-2760-D$ through D-RD-2764-D

(b) Contents:

(1) Type and form of material:

Any solid, large quantity of radioactive materials, fissile and nonfissile, meeting special form or packaged in DOT Specification $2 R$ Inner container and whose decay heat load does not exceed 300 watts.

(2) External radiation levels will be within the levels prescribed in DOT Regulations, Title 49.

(3) Specific limits of contents:

$$
\begin{aligned}
& \text { (i) } 5 \mathrm{~g} \text {. of: } \\
& { }^{242} \mathrm{Am},{ }^{244} \mathrm{Cm},{ }^{245} \mathrm{Cm},{ }^{247} \mathrm{Cm},{ }^{249} \mathrm{Cf} \text { or }{ }^{251} \mathrm{Cf} \\
& \text { (ii) } 150 \mathrm{~g} \text {. of : } \\
& 238 \mathrm{PuO}_{2} \\
& \text { (iii) } 100 \mathrm{~g} \text {. of : } \\
& 235 \mathrm{U}, 233_{\mathrm{U}} \text { or }{ }^{239} \mathrm{Pu}
\end{aligned}
$$

(c) Fissile Class: 
○

-

○

.
•

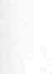
-

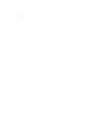
a

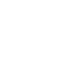
ra .

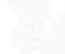


II.B. 35

B. RADIOACTIVE SOLIDS

TUNGSTEN SHIELDED CASKS 
II.B. 36

ORNL Photo 2996-79

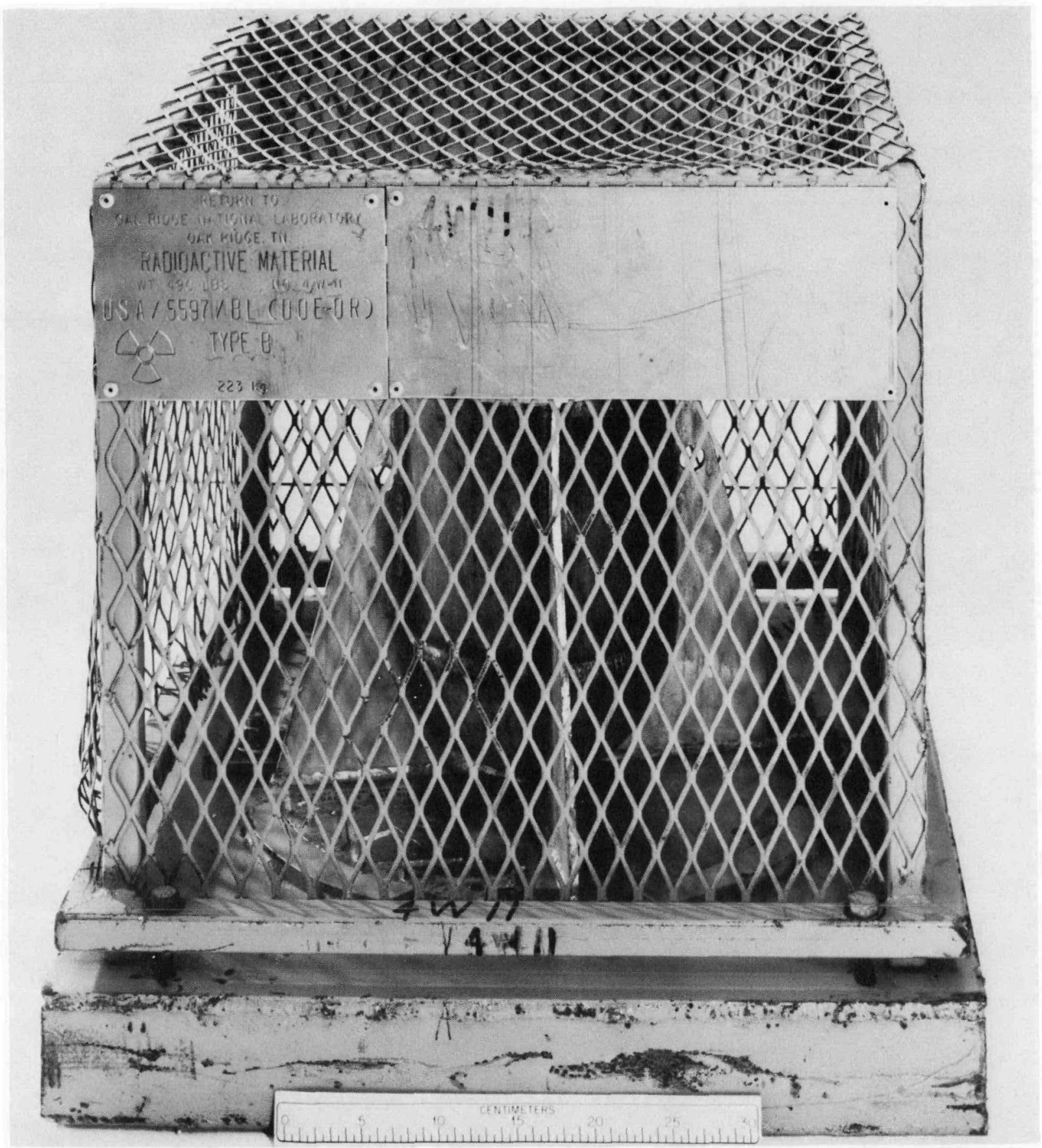

ORNL Tungsten Shielded Type B Container 
II.B. 37

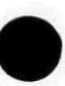

RNL Photo 2541-78

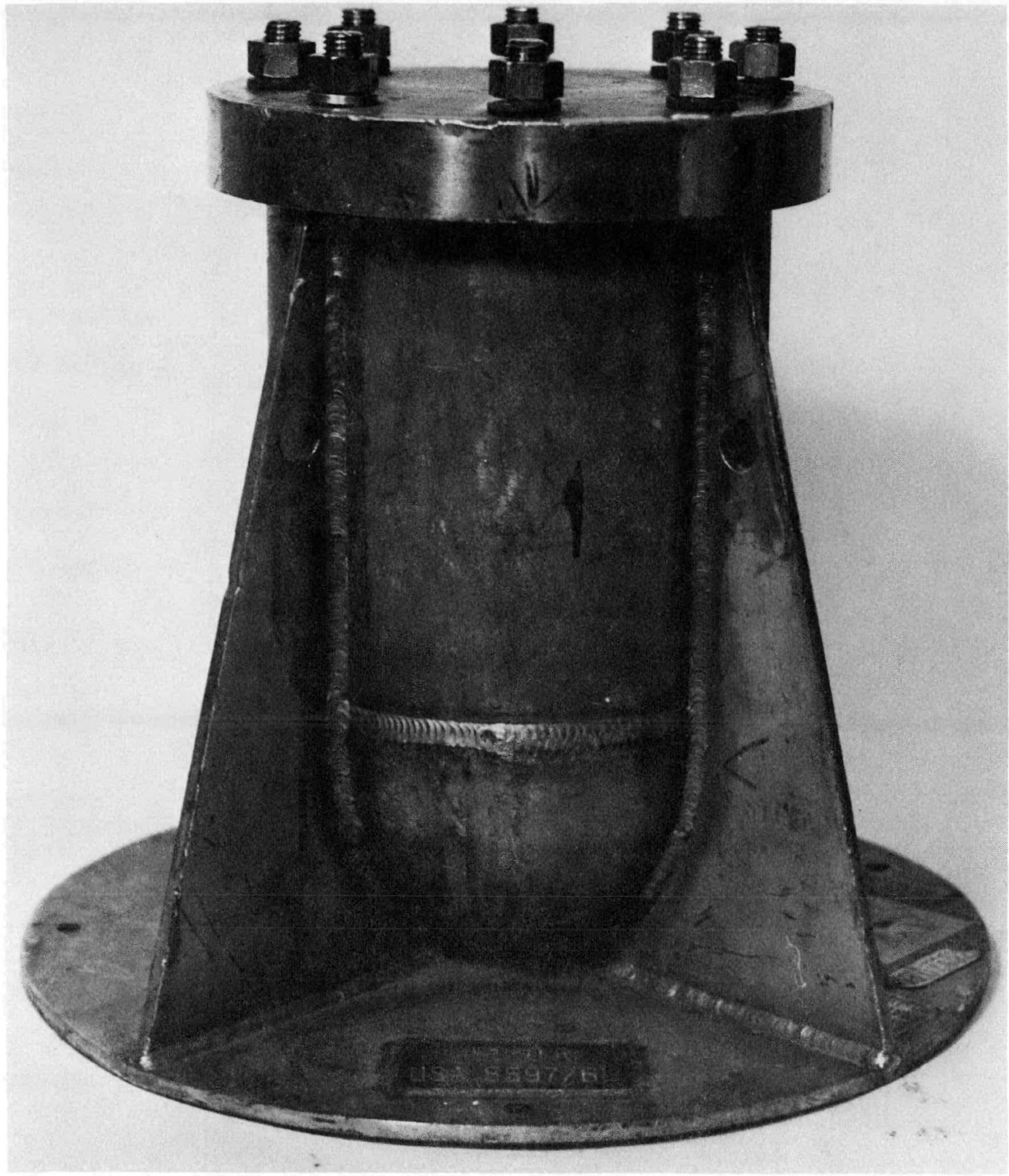

ORNL Tungsten Shielded Type B Container 


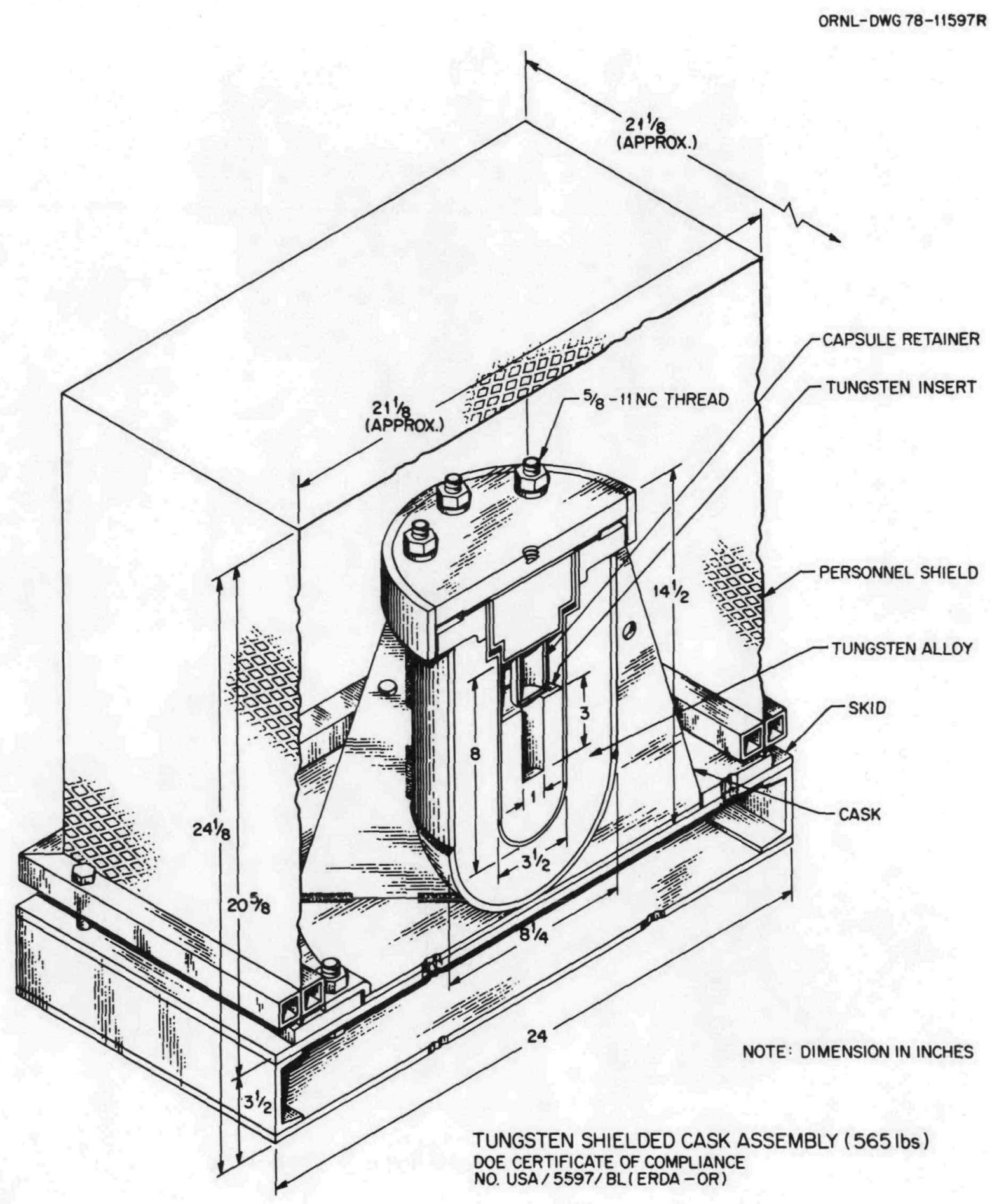




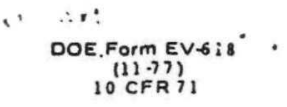

\begin{tabular}{|c|l|l|c|c|}
\hline $\begin{array}{c}\text { 1a. Certificate Number } \\
5597\end{array}$ & $\begin{array}{l}\text { 1b. Revision No. } \\
2\end{array}$ & $\begin{array}{l}\text { 1c. Package Identification No. } \\
\text { USA/5597/BL (DOE-OR) }\end{array}$ & $\begin{array}{c}\text { 1d. Page No. } \\
1\end{array}$ & $\begin{array}{c}\text { 1e. Total No. Pages. } \\
2\end{array}$ \\
\hline
\end{tabular}

2. PREAMBLE

2a. This certificate is issued to satisfy Sections 173.393a, 173.394, 173.395, and 173.396 of the Depertment of Transportation Hazardous Materials Regulations (49 CFR 170-189).

2b. The packaging and contents described in item 5 below, meets the safety standards set forth in Subpart C of Title 10, Code of Federal Regulations, Part 71, "Packaging of Radioactive Material for Transport and Transportation of Radioactive Material Under Certain Conditions."

2c. This certificate does not relieve the consignor from compliance with any requirement of the regulations of the U.S. Department of Transportation or other applicable regulatory agencies, including the government of any country through or into which the package will be transported.

3. This certificate is issued on the basis of a safety analysis report of the package design or application-

(1) Prepared by (Name and address):

(2) Title and Identification of report or application:

(3) Date:

Oak Ridge National Laboratory

Post Office Box X

Oak Ridge, Tennessee 37830

a) Safety Analysis Report for the ORNL Tungsten-Shielded Cask, Report No. ORNL/ENG/TM-3

b) Safety Analysis Report for the ORNL

a) 0 ct. 1977 Tungsten-Shielded Cask, Addendum 1, Report No. ORNL/ENG/TM-3, Addendum 1.

4. CONDITIONS

This certificate is conditional upon the fulfilling of the requirements of Subpart D of 10 CFR 71 , as applicable, and the conditions specified in item 5 below.

5. Description of Packaging and Authorized Contents, Model Number, Fissile Class, Other Conditions, and References:

a. Packaging:

(1) Model: Tungsten-Shielded Cask

(2) Description:

The packaging consists of a right circular cylinder with a hemispherical bottom. It has a maximum outside diameter of 16-in. at the base. The cask itself has an outside diameter of $8-i n$. The overall height is 15-1/4-in. Inner cavity dimensions are 3.120-in. diam. by 6-1/2-in. high. Shielding is composed of a 2 " thickness of isostatically pressed and sintered tungsten alloy containing $95 \%$ tungsten, $3.5 \%$ nickel, and $1.5 \%$ iron, with a $1 / 4-i n$. type $304 \mathrm{~L}$ stainless steel cladding outside and a 1/8-in. type 304L stainless steel cladding inside. The gasketed lid consists of a 150-1b. flange to which the top shield plug is attached and is held in place by eight 5/8-in. studs and bolts. A capped 1-in. pipe is welded to the underside of the cask lid to position the contents. The gross weight of the basic cask is 381 1bs.

A tungsten insert, heat shield, and skid are utilized for shipping radioactive materials having higher internal heat loads and external radiation levels. The gross weight of the cask, insert, heat shie ${ }^{\top} \mathrm{d}$ and skid is $565 \mathrm{lb}$.

\begin{tabular}{l|l}
\hline 6a. Date of Issuance: JAi $25 T 979$ & 6b. Expiration Date: \\
\hline 7a. Address (of DOE Issuing Office) & FOR THE U.S. DEPARTMENT OF ENERGY \\
\begin{tabular}{l|l} 
U. S. Department of Energy & 7b. Signature, Name, and Title (of DOE Approving Official) \\
Post Office Box E & William H. Travis, Director \\
Oak Ridge, Tennessee 37830 & Safety and Environmental Control Division \\
&
\end{tabular}
\end{tabular}


II.B. 40

Certificate No. 5597

2

(3) Drawings:

The packaging is as described and fabricated in accordance with Oak Ridge National Laboratory Drawings No. M-11575-EM-001-E-

Rev. 2, X3D11575-002, and X3D-11575-003-Rev. 3.

b. Contents:

(1) Type and Form of Material:

Non-fissile radioactive materials as solid and in special form.

(2) Maximum quantity of material per package may be a large quantity and not to exceed 25 watts of thermal decay energy without the insert, heat shield, and skid and not to exceed 50 watts of thermal decay energy with the insert, heat shield, and skid. The radioactive contents will be further limited by authorized external radiation levels specified in Department of Transportation (DOT) Regulations. 
II.B. 41

B. RADIOACTIVE SOLIDS

TRU CURIUM SHIPPING CONTAINER 
ORNL Photo 0784-74 R2

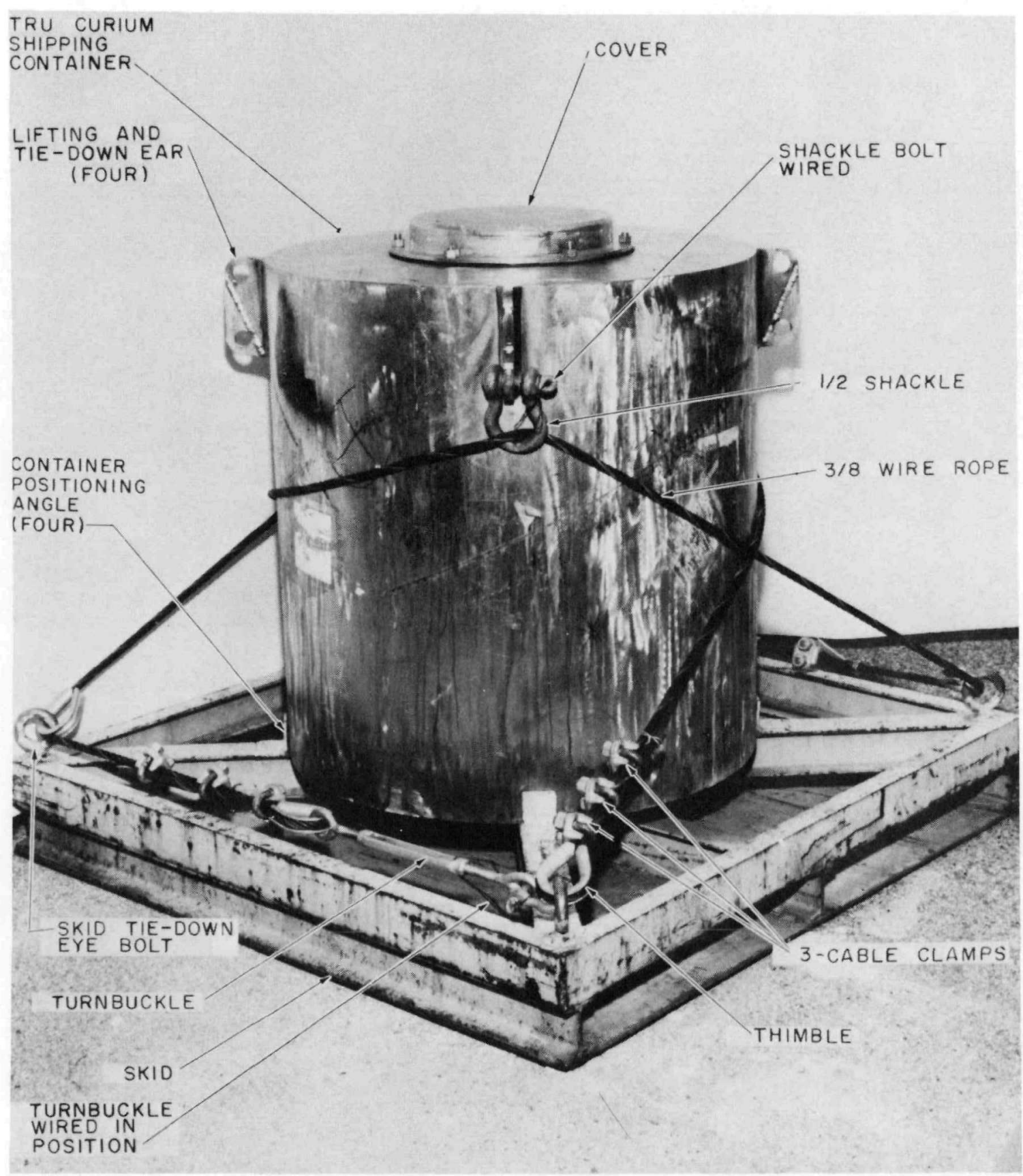

ORNL TRU Shipping Container - Type B 
II.B. 43

ORNL DWG 67-9810

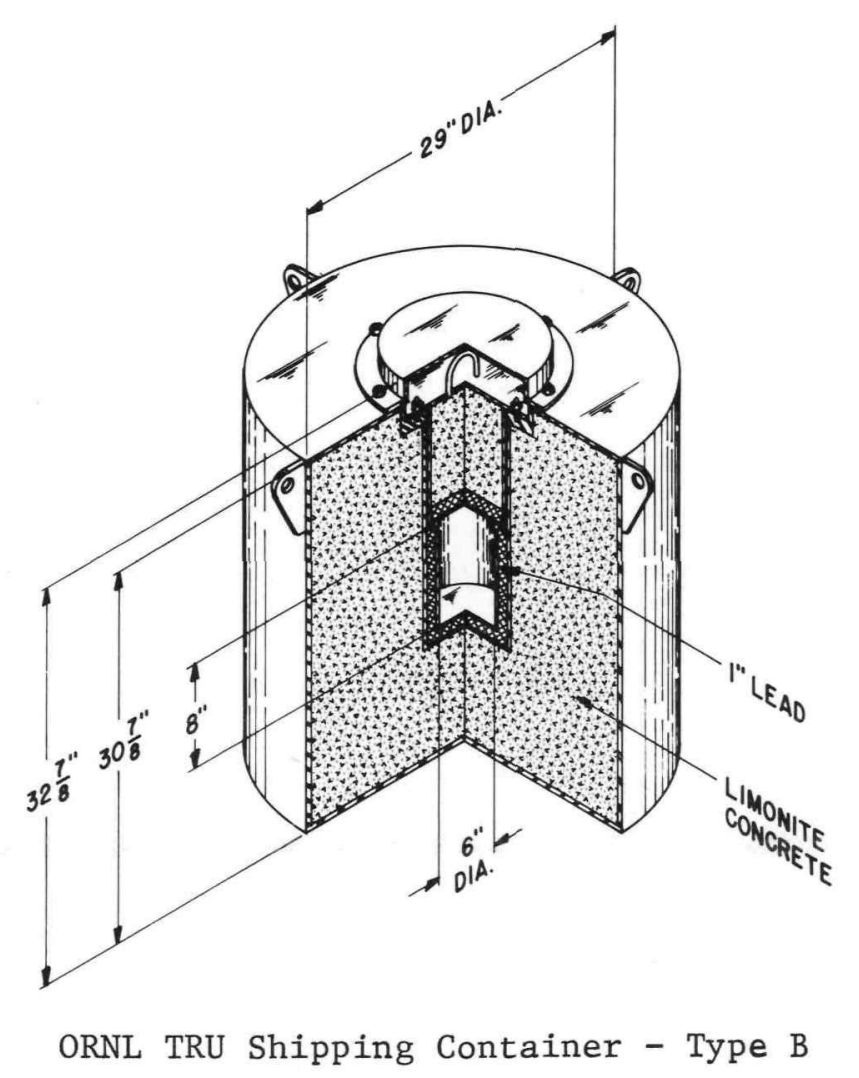




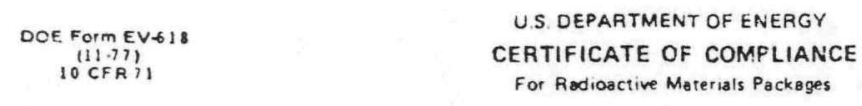

\begin{tabular}{|c|c|c|c|c|c|}
\hline \multicolumn{2}{|c|}{$\begin{array}{l}\text { 1a. Ceristicate Number } \\
5461\end{array}$} & $\begin{array}{l}\text { I0. Fevision No. } \\
1\end{array}$ & $\begin{array}{l}\text { 1c. Package Identification No. } \\
\text { USA/5461/BL (DOE-OR) }\end{array}$ & $\begin{array}{c}\text { 1d. Page No. } \\
1 .\end{array}$ & $\begin{array}{l}\text { 1e. Tota: No. Pages. } \\
2\end{array}$ \\
\hline \multicolumn{6}{|c|}{ 2. PAEAMBLE } \\
\hline $2 a$. & \multicolumn{5}{|c|}{ This certificate is issued to satisfy Sections } \\
\hline $2 \mathrm{~b}$. & \multicolumn{5}{|c|}{$\begin{array}{l}\text { The packaging and contents described in item } 5 \text { below, meets the safety standards set forth in Subpart C of Title 10, Code of Fede:at } \\
\text { Regulations, Fart 71. "Packag'ng of Radioactive Material for Transport and Tiansportation of Radioactive Material Under Certain } \\
\text { Conditions." }\end{array}$} \\
\hline $2 c$ & \multicolumn{5}{|c|}{$\begin{array}{l}\text { This der tificale does not relieve the consignor trom compliance with any requirement of the regulations of the U.S. Department of } \\
\text { Transportaition or oither appicabie regulatory agencies, includ. ing the governmen: of any country through or into which the peckeue } \\
\text { will be transported. }\end{array}$} \\
\hline
\end{tabular}

3. This certificate is issued on the basis of a safety analysis report of the package design or application -

(1) Prepared by iName and address:

Oak Ridge National Laboratory

Post Office Box X

Oak Ridge, Tennessee 37830

(2) Title and identification of report or application.

Safety Analysis Report for Packaging

(SARP) of the Oak Ridge National Laboratory

TRU Curium Shipping Container

Report No.: ORNL-5147/RI

\footnotetext{
4. CONDITIONS

This certificate is conditional upon the fulfilling of the requirements of Subpart D of 10 CFR 71, as applicable, and the conditions specified This certificale
in tem 5 below.

5. Description of Packaging and Authorized Contents, Model Number, Fisstle Class, Other Conditions, and References:
}

a. Packaging:

(1) Model: ORNL TRU Curium Shipping Container

(2) Description:

Packaging for solid radioactive materials. The container is a right circular cylinder $29 \mathrm{in}$. in diameter and $307 / 8 \mathrm{in}$. high with a 304L stainless steel outer she11, which is $3 / 8 \mathrm{in}$. thick for the bottom and sides and $1 / 4 \mathrm{in}$. for the top. The shell for inner cavity is $81 / 4 \mathrm{in}$. diameter $\times 191 / 4 \mathrm{in}$. deep, is fabricated from $1 / 4$ in. thick $304 \mathrm{~L}$ stainless steel plate, and is recessed $13 / 8 \mathrm{in}$. from the top. The cavity shell is a cylinder $81 / 4 \mathrm{in}$. diameter $x 191 / 4 \mathrm{in}$. high and is fabricated from $1 / 4 \mathrm{in}$. thick $304 \mathrm{~L}$ stainless steel. The inner cavity for the radioactive materials is 6 in. diameter $x 8$ in. high and fabricated from $1 / 4$ in. thick $304 \mathrm{~L}$ stainless steel. Seven-eights in. thick lead fills the space between the sides and bottom of the cavity shell and the inner cavity. The annulus between the outer she11 and inner shell is filled with limonite concrete.

The inner cayity is closed with a concrete-and-lead plug which is enclosed in 1/4 in. 304L stainless steel plate. A 1/16 in. thick neoprene gasket serves as a seal between the top flange of the plug and the cask body. Eight

\begin{tabular}{|c|c|}
\hline 6e. Date of Issuance October 1, 1979 & 60. Expiration Date: \\
\hline \multicolumn{2}{|c|}{ FOR THE US DEPARTMENT OF ENERGY } \\
\hline 7a. Adderss for DOE Issuing Office) & 7b. Signature, Name, and Titie Tof DOE Approving Officiail \\
\hline $\begin{array}{l}\text { v. S. Departuent of Energy } \\
\text { Post Office Box E } \\
\text { Oak Ridge, TN } 37830\end{array}$ & $\begin{array}{l}\text { William H. Travis, Director } \\
\text { Safety and Environmental Control Division }\end{array}$ \\
\hline
\end{tabular}


Page 2 - Certificate of Compliance USA/5461/BL

(2) Description (continued)

I/2 ia. $x 13$ NC-2 nuts on studs hold the plug flange to the cask body. A $3 / 8$ in. diameter $304 \mathrm{~L}$ stainless steel bail is used to lift the plug.

A $1 / 4 \mathrm{in}$. thick $304 \mathrm{~L}$ stainless steel plate, which covers the top flange and bail, is held to the top of the cask by six 1/2 in. $x$ $13 \mathrm{NC}-2$ nuts on studs.

The cask is equipped with four $1 / 2 \mathrm{in}$. thick lifting and tie-down ears with two 1 in. diameter holes per ear. The cask is also mounted on a skid for handling with a forklift.

The gross weight of the cask and skid is $28001 \mathrm{~b}$.

(3) Drawing:

The packaging for the TRU Curium Shipping Container 1s constructed in accordance with Oak Ridge National Laboratory Drawing No. M-12175CP-078-E-3.

b. Contents:

(1) Type anf Form ố Material:

Any isotope of plutonium, americium, curfum, berkelium, californium; and fermium in the form of metal, oxide, chloride or other salt.

(2) Maximum quantity of material per package:

(i) A total of $10 \mathrm{~g}$ of ${ }^{239} \mathrm{Pu},{ }^{241} \mathrm{Pu},{ }^{242} \mathrm{Am},{ }^{243} \mathrm{Cm},{ }^{245} \mathrm{Cm},{ }^{247} \mathrm{Cm}$, and/or ${ }^{249} \mathrm{Cf}$.

(ii) $3 g$ of ${ }^{25 l} \mathrm{Cf}$.

(iii) The balance of the transuranic and other non-fissile radioactive materfals will be limited to a hat load of $500 \mathrm{Btu} / \mathrm{hr}$. and to the external radiation levels specified in US DOT Regulations 49 CFR Part 173.393.

(iv) Contents are either singly or doubly encapsulated in a welded container meeting spectal form raquirements and may be further placed in anotier DOT Speciflcation $2 R$ container for handling purposes.

Revised $3 / 1 / 81$ 
0

0

0 
II.B. 47

B. RADIOACTIVE SOLIDS

TRU TEN-TON CALIFORNIUM SHIPPING CONTAINER 
ORNL Photo 2453-78

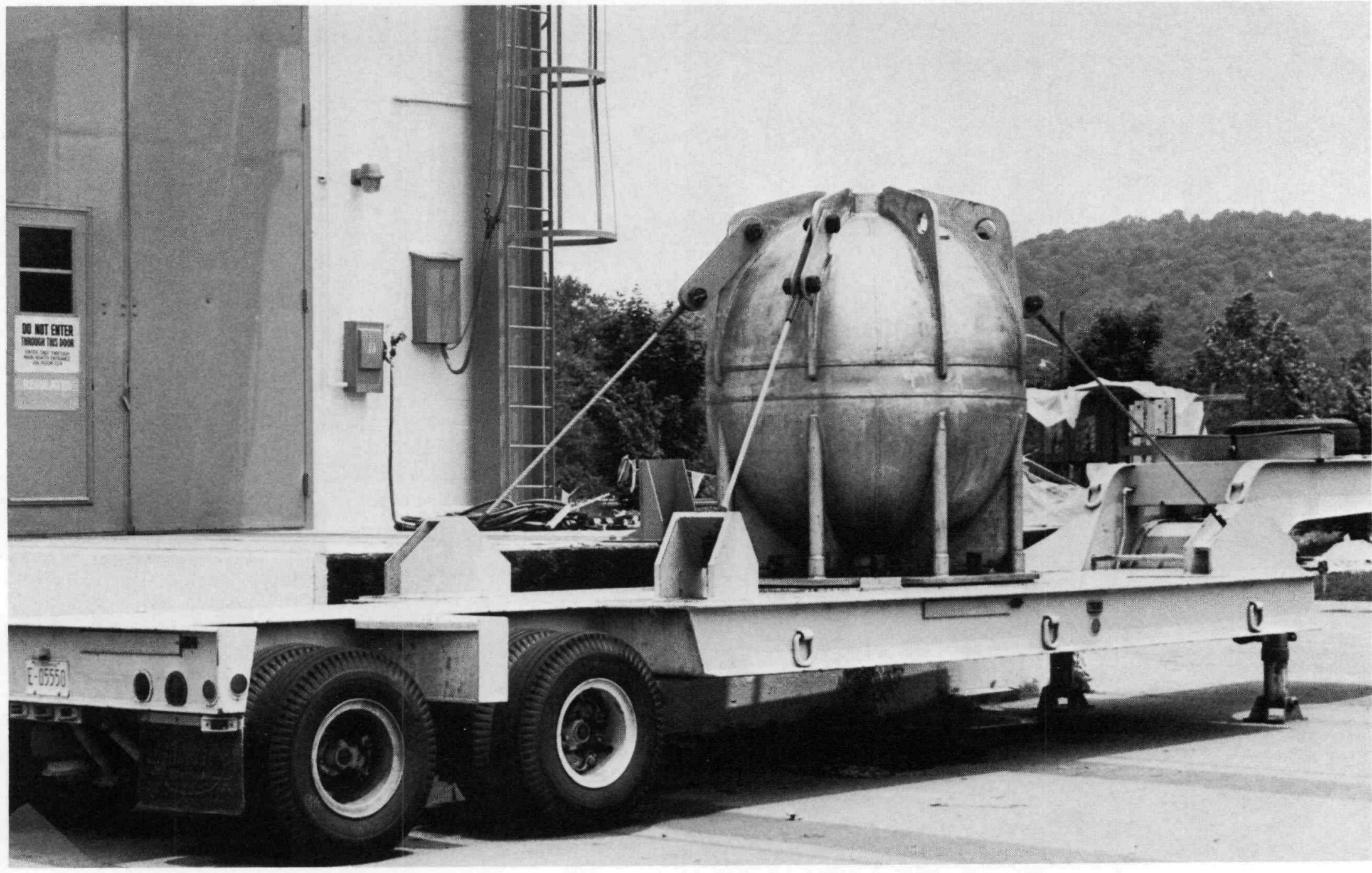

ORNL TRU Californium Shipping Container - Type B 
II.B. 49

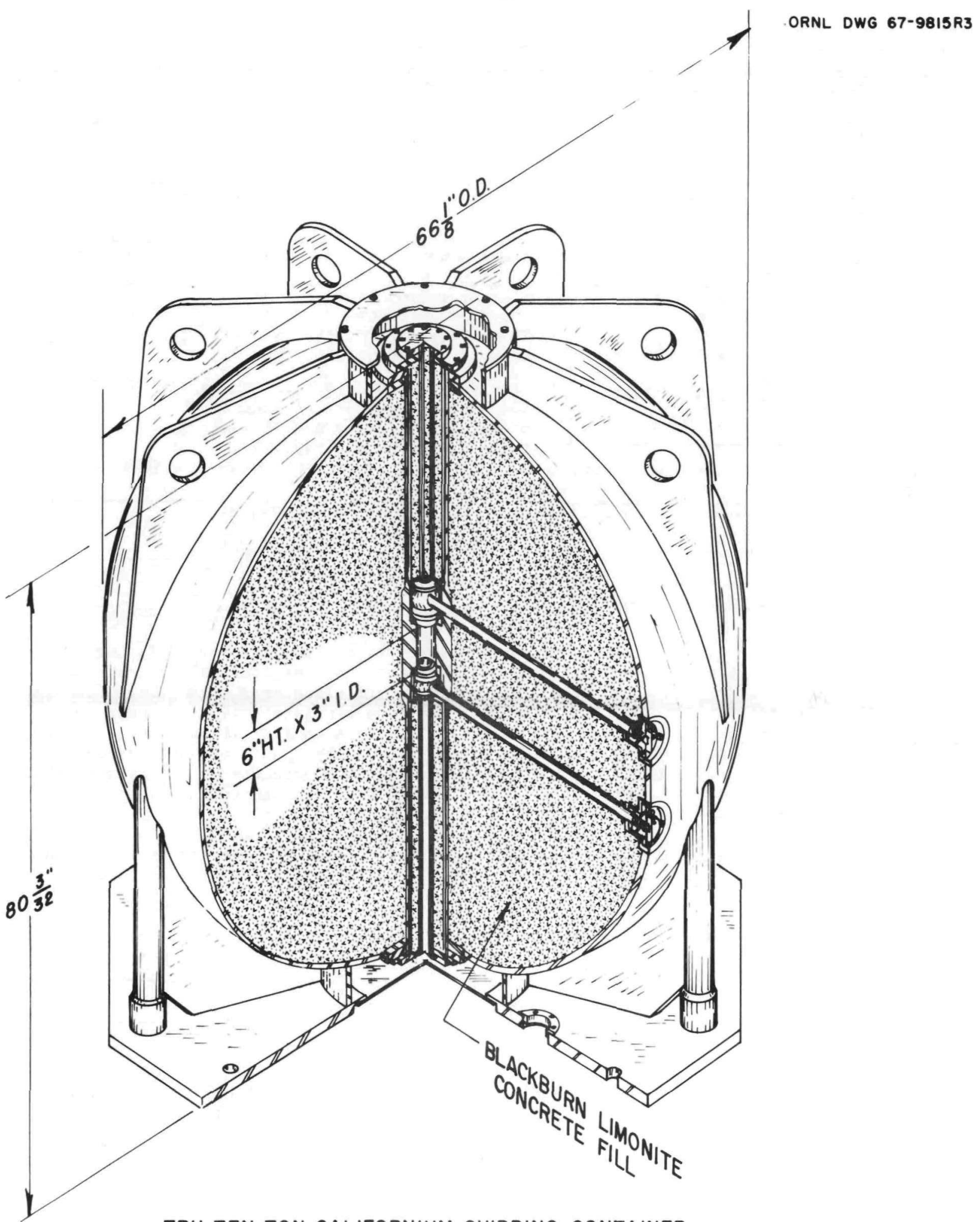

TRU TEN TON CALIFORNIUM SHIPPING CONTAINER 
ค

DOE Form EV 61 :

U.S. DEPARTMENT OF ENERGY

, 10 CFR (11)

CERTIFICATE OF COMPLIANCE

For Radionctive Mareriais Packages

\begin{tabular}{|c|c|c|c|c|c|}
\hline \multicolumn{2}{|c|}{ 1a. Certificate Number } & $\begin{array}{l}\text { 16. Revision No. } \\
1\end{array}$ & $\begin{array}{l}\text { 1c. Package Identification No. } \\
\text { USA/5740/BL. }\end{array}$ & $\begin{array}{c}\text { 1d. Page No. } \\
\end{array}$ & 16. Total No. Pagen. \\
\hline \multicolumn{6}{|c|}{ 2. PREAMBLE } \\
\hline 2a. & \multicolumn{5}{|c|}{$\begin{array}{l}\text { This cerrificate is issued to satisty Sections 173.393a, 173.394, 173.395, and } 173.396 \text { of the Depertment of Transportation Hazardous } \\
\text { Materials Regulations (49 CFR 170-189). }\end{array}$} \\
\hline 2b. & \multicolumn{5}{|c|}{$\begin{array}{l}\text { The pedaging and contents described in item } 5 \text { below, meets the safory standards set forth in Subpart C of Title 10, Code of Federal } \\
\text { Regulations, Part } 71 \text {. "Packaging of Radicactive Material for Transport and Transportation of Radioactive Material Under Cortain } \\
\text { Conditions." }\end{array}$} \\
\hline 2c. & \multicolumn{5}{|c|}{$\begin{array}{l}\text { This cortificate does not relieve the consignor from compliance with any requirement of the regulations of the U.S. Department of } \\
\text { Transportation or other applicable regulatory agencies, including the government of any country through or into which the package } \\
\text { will be transported. }\end{array}$} \\
\hline
\end{tabular}

3. This certificate is issued on the basis of a safery analysis report of the package design of application-

\begin{tabular}{l|ll} 
(1) Prepared by (Name and address): & (2) Title and Identification of report or application: (3) Date:
\end{tabular}

Oak Ridge National Laboratory

Post Office Box X

Oak Ridge, Tennessee 37830

(a) The TRU Ten-Ton Californium Shipping (a) Nov. 19? Container, Report ORNL-TM-3505.

(b) Safety Analysis Report for Packaging (b) To be (SARP) of the Oak Ridge National Lab- issued oratory TRU Californium Shipping Container, Report ORNL-5409, Rev. 1.

4. CONDITIONS

This certificate is conditional upon the fulfilling of the requirements of Subpart D of 10 CFR 71, as applicable, and the conditions specified in item 5 betow.

5. Description of Packaging and Authorized Contents, Model Number, Fissile Class, Other Conditions, and Referencos:

(a) Packaging

(1) Model: ORNL TRU Californium Shipping Container

(2) Description: A 304L stainless steel encased concrete shipping cask

The outer shell consists of two $\frac{1}{2}-i n$. thick, 66-in. diameter hemispherical heads joined by a 6-in. cylindrical section. The cylindrical cavity has a 1-1n. thick stainless steel wall and is 3-in. diamater $\times 6-i n$. 1ong. Shielding consists of 30-in. of Blackburn limonite concrete having a density of $2175 \mathrm{lb} / \mathrm{ft}^{3}$.- Upper and lower level ball valves located at the end of concret filled plugs define, isolate, and seal the cavity. Both of these plugs which utilize 0-ring seals are bolted in place and are protected with a gasketed cover plate. Fusible plugs in the cover plates and the shell will melt to permit steam release in event of thermal exposure.

The top ball valve and plug may be replaced by other plugs for multiple sourc shipments. Sources are contained in DOT Specification 2R or special-form containers.

The cask is mounted onto a 1-in. thick steel base plate by eight steel $2 \frac{1}{2}-1 \mathrm{a}$. NPS Schedule 40 pipe struts. The cask is transported on its own special \begin{tabular}{cc|c|c|}
\multicolumn{1}{c}{ trailer. The gross weight of the cask is 23.5 } \\
\hline January 19, 1979 & 6b. Expiration Date:
\end{tabular} FOR THE U.S. DEPARTMENT OF ENERGY

\begin{tabular}{l|l} 
7a. Address (af DOE lssuing Office) & 7b. Signature, Name, apd Title lof DOE Approving Officiall)
\end{tabular}

U. S. Department of Energy

Post Office Box E

Oak Ridge, Tennessee 37830

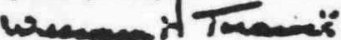

William H. Travis, Director

Safety \& Environmental Control Division 
II.B. 51

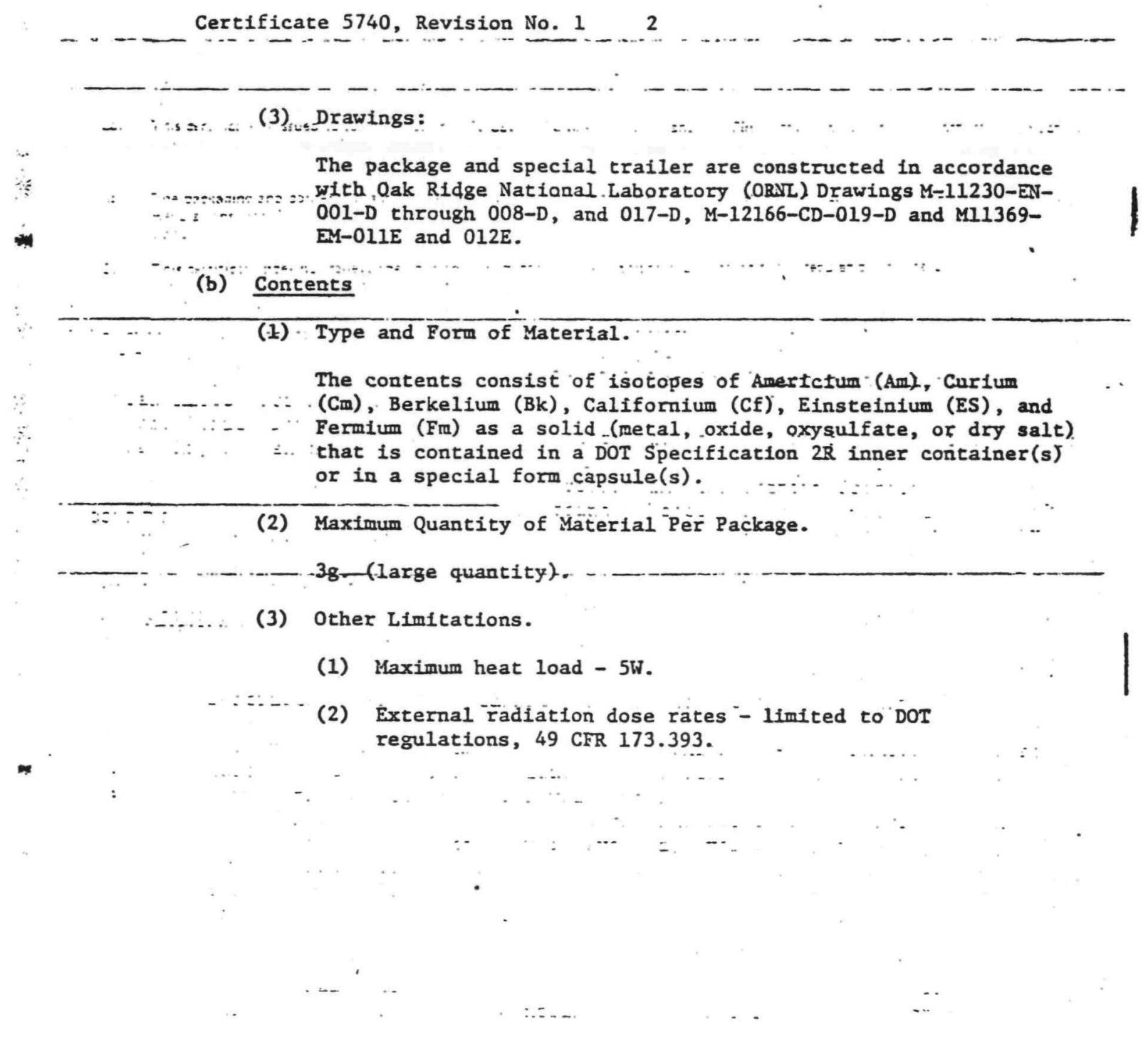


-

○

○ 
II.B. 53

B. RADIOACTIVE SOLIDS

D-38 URANIUM SHIELDED SHIPPING CASK 
ORNL Photo 94766

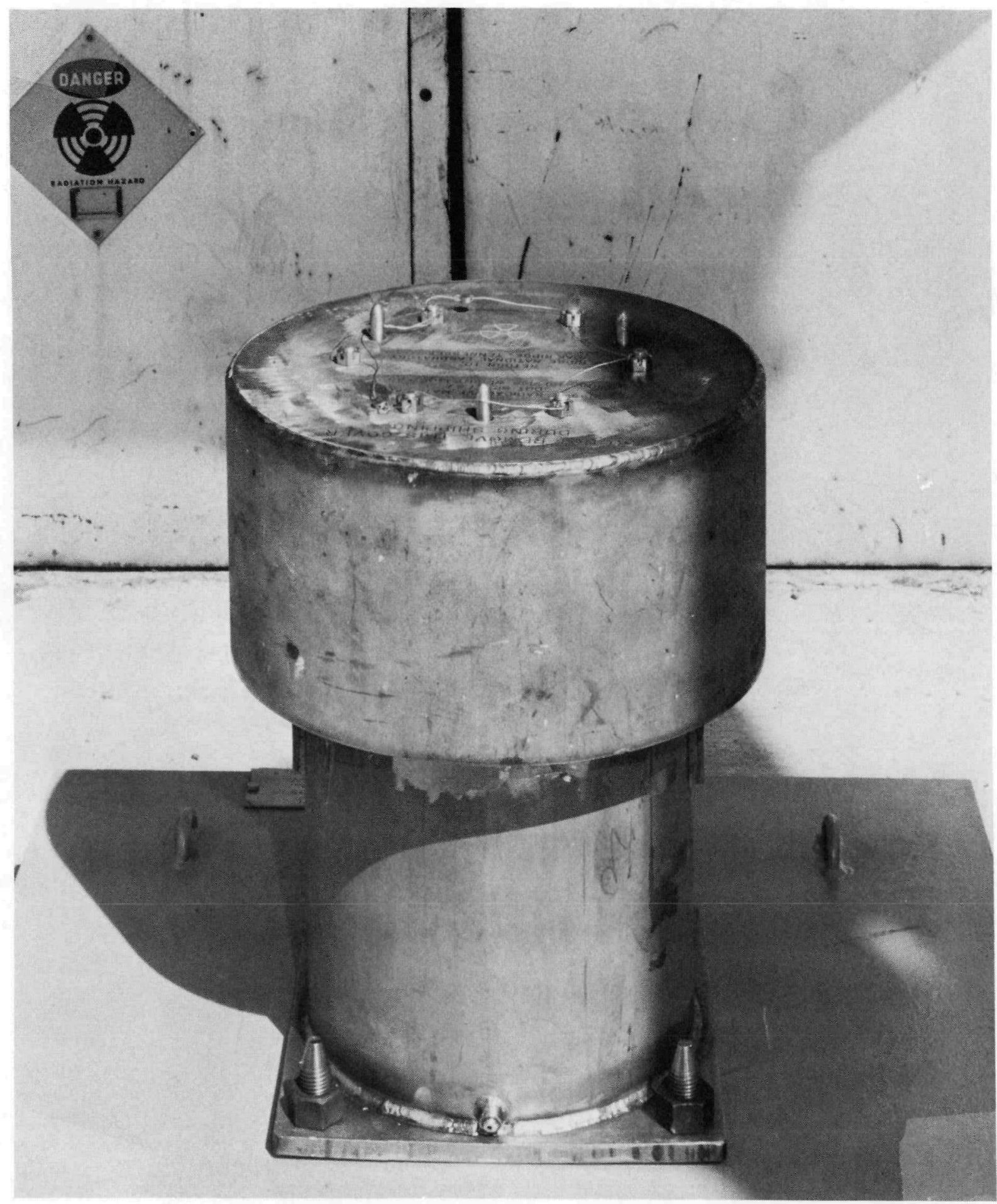

ORNL D-38 Uranium Shielded Container

Type B 
II.B. 55

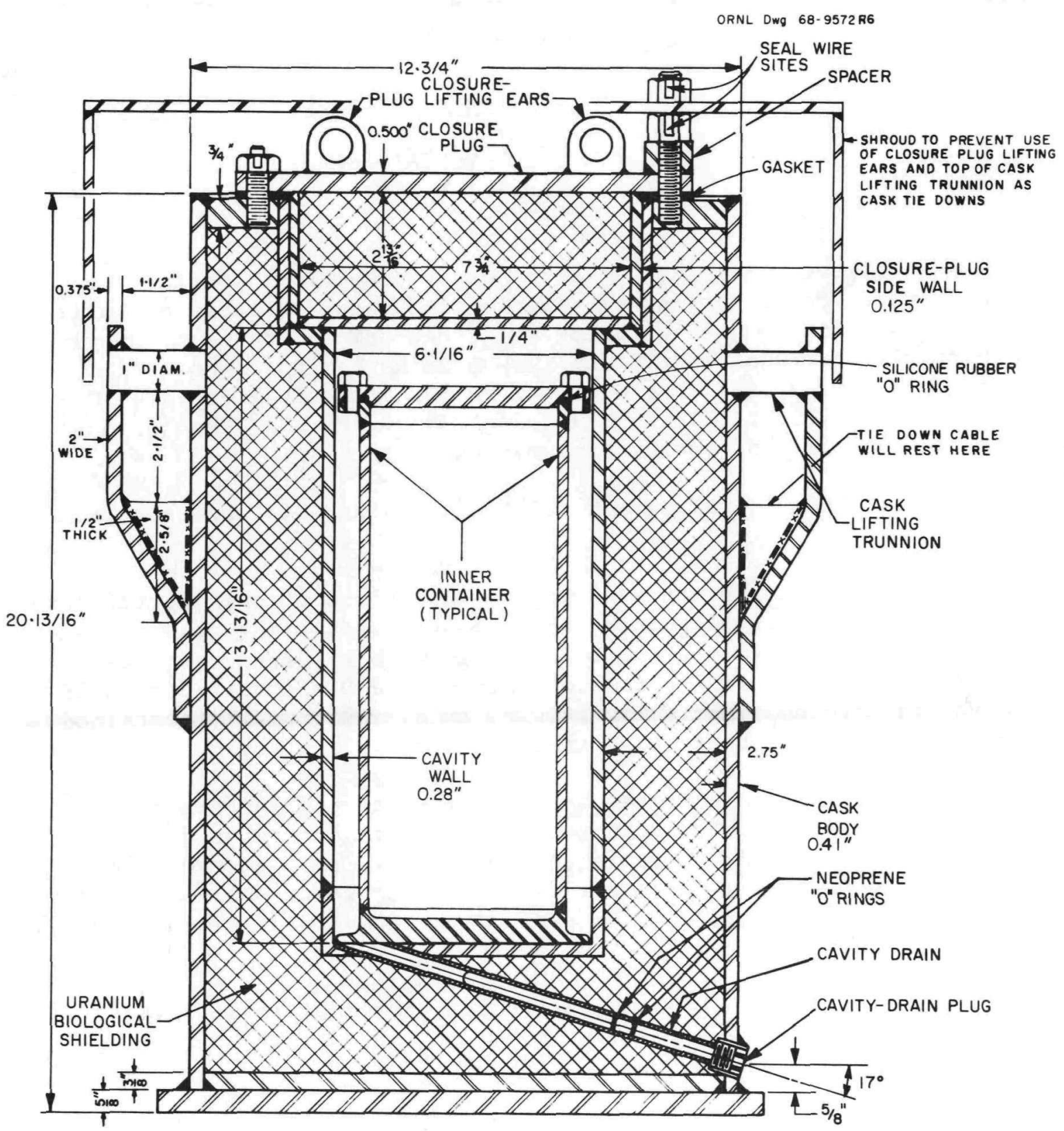

ORNL D-38 Uranium Shielded Container Type B 


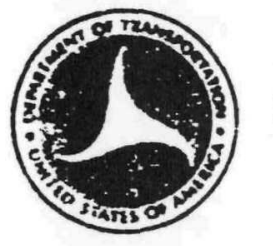

\author{
DEPARTMENT OF TRANSPORTATION \\ RESEARCH AND SPECIAL PROGRAMS ADMINISTRATION \\ WASHINGTON. D.C. 20500
}

IAEA CERTIFICATE OF COMPETENT AUTHORITY

Type B Fissile Radioactive Material Package Design

$\frac{\text { Certificate Number USA } / 5787 / B() F}{(\text { Revision } 1)}$

This establishes that the packaging design described herein, when loaded with the authorized radioactive contents, has been certified by the National Competent Authority of the United States as meeting the regulatory requirements for Type $B$ packaging for fissile radioactive materials as prescribed in IAEA Regulations 8549 CFR $173.393 b, 173.395(c)(2)$ and $173.996(c)(3)$ of the USA ${ }^{2}$ Regulations for the transport of radioactive materials.

I. Package Identification - Model D-38 Uranium Shielded Shipping Cask.

II. Packaging Description - Packaging authorized by this certificate consists of a stainless steel, uranium shielded, right cylindrical cask $123 / 4^{\prime \prime}$ in diameter by $225 / 8^{\prime \prime}$ high with a bolted, gasketed closure. Contents are further contained in a DOT specification $2 R$ or equivalent container, with liquids to be additionally contained in polyethylene or stainless steel bottles.

III. Authorized Radioactive Contents - The authorized contents consist of fissile or large quantities of radioactive materials n.o.s. not to exceed 500 curies, or a thermal decay energy of 80 watts. For fissile radioactive materials, contents shall not exceed 500 grams of uranium-235, 350 grams of uranium-233 or plutonium-239, or 350 grams of any combination thereof.

For fissile materials, shipments are authorized as Fissile Class I.

IV. General Conditions -

a. Each user of this certificate must have in his possession a copy of this certificate.

b. Each user of this certificate, other than the U. S. Department of Energy, Oak Ridge, Tennessee, shall register his identity in writing to the office of Hazardous Materials Regulation, Materials Transportation Bureau, U. S. Department of Transportation, Washington, D. C. 20590. 

c. This certificate does not relieve any consignor or carrier from compliance with any requirement of the Government of any country through or Into which the package is to be transported.

V. Marking and Labeling - The package must bear the marking USA $/ 5787 / B($ ) F as well as the other marking and labels prescribed by the USA Regulations.

VI. Expiration Date - This certificate, unless renewed, expires on January $31,1981$.

This certificate is issued in accordance with the requirements of the IAEA and USA Regulations and in response to the November 25, 1975, petition by the U. S. Energy Research \& Development Administration, Oak Ridge, Tennessee, and in consideration of the associated information provided in USERDA, Oak Ridge Certificate AEC-OR USA/5787/BLF (Appendix A).

Certified by:

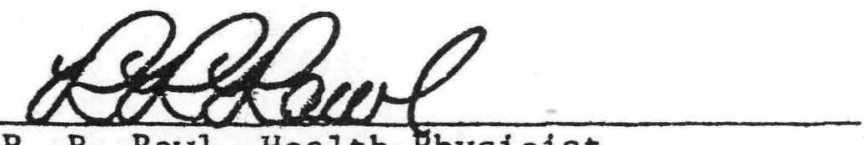

R. R. Rawl, Health Physicist

Office of Hazardous Materials Regulation

U. S. Department of Transportation

Washington, D. C. 20590

\section{Howacey 26,1979}

1"Safety Series No. 6, Regulations for the Safe Transport of Radioactive Materials, 1967 Edftion" published by the International Atomic Energy Agency (IAEA), Vienna, Austria.

2itle 49, Code of Federal Regulations, Parts 100-199, USA.

This certificate supersedes in its entirety DOT Special Permit 5787

with respect to international shipments.

Revision 1 issued to extend expiration date in response to the January 19, 1979, petition by the Department of Energy, Oak Ridge, TN. 
-

Form ACC $\rightarrow 1$

$(0-i 2)$
U.S. ATOMHC CHERGY COR:-:isSION

CERTIFICATE OF COMPLIANCE

For Radicactive Panterials Packeņ?:

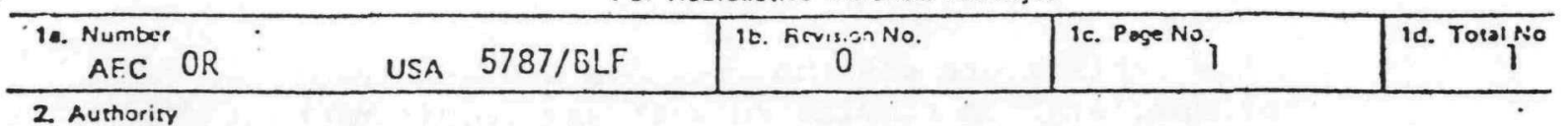

2 Authority

This certificats is issued oursuant to Sections 173.39.4, 173.355, and 173. 05 of the Deporment of Transportation Hazardous Moteria

- Regulations as amended (49 CFR 170-189 and 14 CFR 103), ond AEC A: anual Chapters 5201 aind OJ29.

\section{CONDITICNS}

33. This certificate is issued on the basis of SAFETY ANALYSIS REPORT FOR PACKASING ISARP
(1) Prepured by
Oak Ridge National Laborạtory
(2) Number
P.0. Box $X$
Oak Ridge, Tennessee 37830
ORNIL-Tí-2220
(3) Date Published October 1953

30. The packaging described in the SARP and further described in item 4 beiow, when constructed and assembled as prescribed in the SAR. with the contents as authorized herein, meets the standards prescribed in DOT regulations.

3c. The outside of each packaje must bs plainly and durably marked with the letrers and number shown in item la. on this form in accord. with the standards for markings in paragraph 173.24 (b) of 49 CFA 173.

3d. This certificate does not relieve the consigner from compliance with the regulations of the US. Depaptment of Transportation or other regulatory azencies.

3e. Each user of packages approved undep this certificate shall register his narne and addresa with the issuing office.

4. Description of Packaying and Authorized Contents, Restrictions, and Feterences:

A. The packaging consists of a stainiess-stee? clad, depleted (0.2 wt: 235U) urani: shielded cask, which is a right circular cylinder, 12-3/4" 0.D. $\times$ 22-5/8" high l: a 6" I.D. x 13-13/16" deep central cavity. The uranium shield is 2-3/4" thick. Cask closure is by means of a plug-type uranium-shielded top lid, which is bolte sealed with two neoprene "O"-rings. Contents must be loaded witnin a DOT Speci tion $2 R$ or equivalent, primary inner containnent, with liquids to be additionail contained in polyethylene or stainless bottles. The gross weight of the package about 1300 1b.

B. The authorized contents of each package consist of fissile and large quantities radioactive material N.O.S. in the form of solid and liquid mixed fission produc fuel elements, or waste products. The maximum themal decay energy of the conte: shall not exceed 80 watts and the total radioactivity shall not exceed 500 curie The fissile radioactive material contents shall not exceed $500 \mathrm{~g}$ of $235 \mathrm{U}, 350 \mathrm{~g}$ : $233 \mathrm{U}$ or $239 \mathrm{pu}$, or $350 \mathrm{~g}$ of any combination.

C. Shipments are authorized as Fissile Class I. The Transport Index is assigned on basis of external radiation levels.

D Shinrents aro authorized by vessel and motor vehicle.

\begin{tabular}{|c|c|}
\hline \multirow{3}{*}{$\begin{array}{l}\text { 5. Address lof AEC Approving Olficiall } \\
\text { U.S. Atcmic Energy Comission } \\
\text { P.O. Box E } \\
\text { Oak Ridge, Tennessee } 37830\end{array}$} & 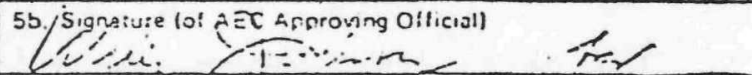 \\
\hline & $\begin{array}{l}\text { 5c. Name and Ti:c (ol AEC Appraving Olfucial)- } \\
\text { billiani if. Travis, Director } \\
\text { safety? Envirnnantal Control divisi }\end{array}$ \\
\hline & \begin{tabular}{l|l} 
6. Expiration $\mathrm{D}_{3}: \mathrm{e}(1 \mathrm{f}$ aspropriate) & $\begin{array}{l}\text { 7. Date } \\
\text { Seotember } 21 .\end{array}$ \\
\end{tabular} \\
\hline
\end{tabular}


II.B. 59

B. RADIOACTIVE SOLIDS

HFIR IRRADIATED FUEL ELEMENT CASK 
ORNL Photo 2376-78

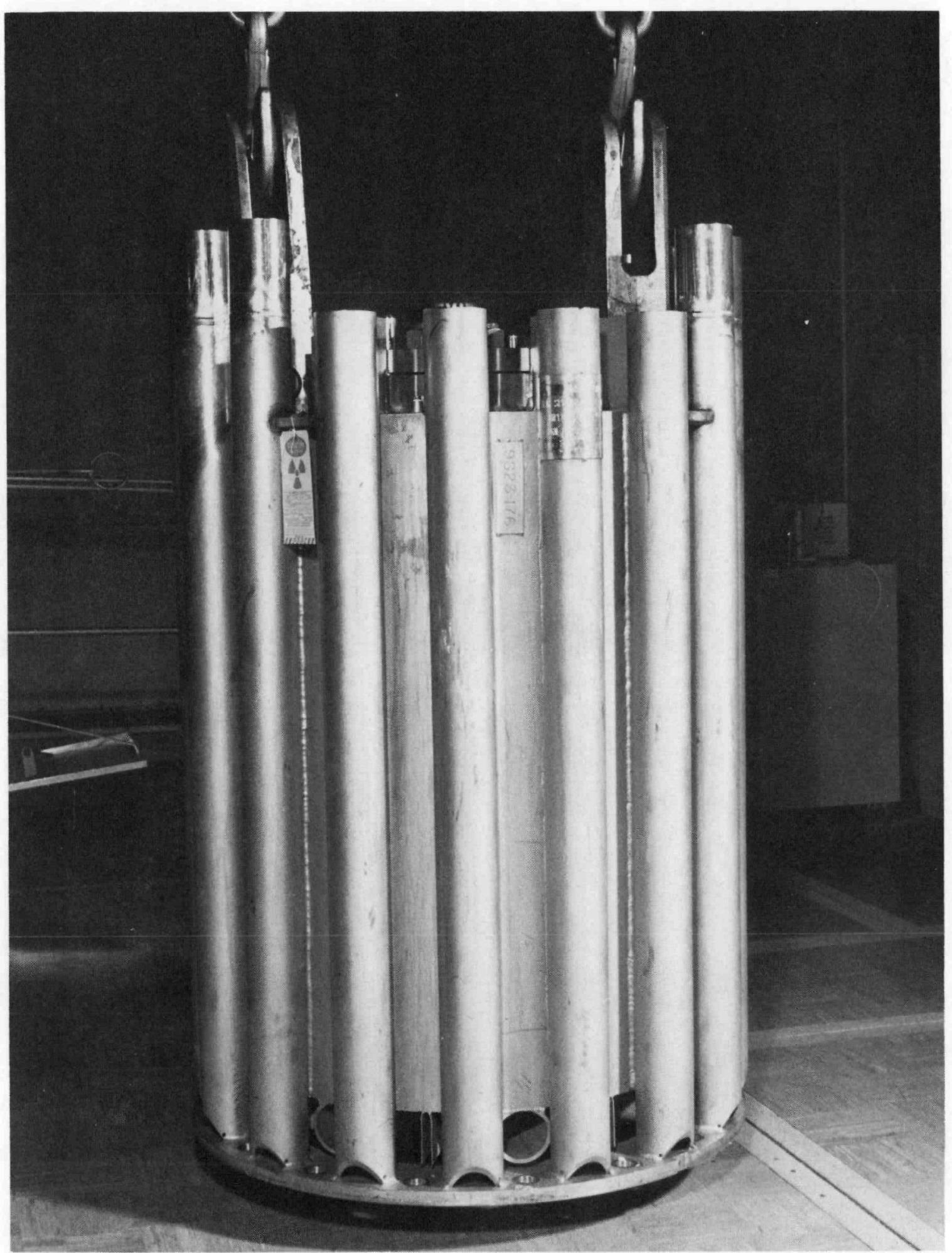

ORNL HFIR Irradiated Fue1 Element Container Type B 
II.B. 61

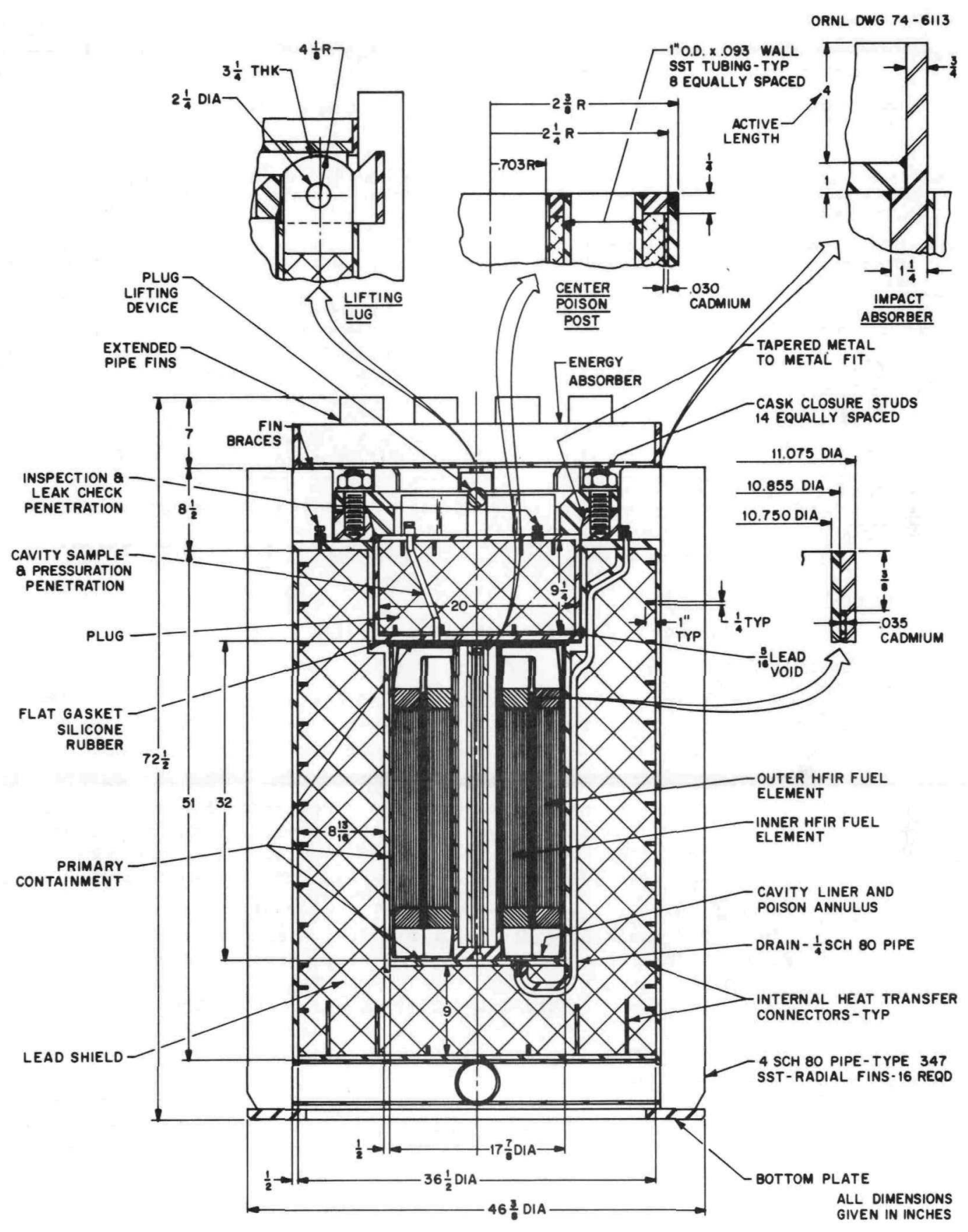

ORNL HFIR Irradiated Fue1 Element Container Type B 
-

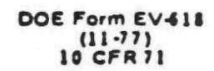

\begin{tabular}{l|l|l|l|l}
\hline $\begin{array}{l}\text { 10. Cortificate Number } \\
5507\end{array}$ & $\begin{array}{c}\text { 1b. Revision No. } \\
7\end{array}$ & $\begin{array}{c}\text { 1c. Package Identification No. } \\
\text { USA/5507/BLF (DOE-OR) }\end{array}$ & $\begin{array}{c}\text { dd. Page No. } \\
1\end{array}$ & $\begin{array}{c}\text { 1e. Total No. Pages. } \\
3\end{array}$ \\
\hline 2. PREMBLE
\end{tabular}

2. PREAMBLE

2a. This certificate is issued to satisfy Sections 173.393a, 173.394, 173.395, and 173.396 of the Depertment of Transportation Hazardous Materials Regulations (49 CFR 170-189).

2b. The packaging and contents deseribed in item 5 below, meets the safety standards set forth in Subpart C of Title 10, Code of Federal Regulations, Part 71, "Packaging of Radioactive Material for Transport and Transportation of Radiosetive Material Under Certain Conditions."

2c. This certificate does not relieve the consignor from compliance with any requirement of the regulations of the U.S. Depertment of Transportation or other applicable regulatory agenciss, including the government of any country through or into which the pack age will be transported.

3. This certificate is issued on the basis of a safety analysis report of the package design or application-

(i) Propared by (Name and address):

Oak Ridge National Laboratory

Post Office Box X

Oak Ridge, TN 37830

(2) Title and Identification of report or apolication:

(3) Date:

a. Safety Analysis Report for Pack- November 1977 aging (SARP) - HFIR Spent Fuel Element Shipping Cask

Report No.: ORNL/ENG/TM-12

(Continued on next page)

4. CONDITIONS

This certificate is conditional upon the fulfilling of the requirements of Subpert D of 10 CFR 71, as applicable, and the conditions specified in item 5 below.

5. Description of Packaging and Authorized Contents, Model Number, Fissile Class, Other Conditions, and References:

(a) Packaging:

(1) Mode1: HFIR* Spent Fuel Element Shipping Cask

(2) Description:

Packaging for irradiated fuel elements and 1rradiated UCC prima -y 99 Mo target capsules. The inner cavity is $177 / 8 \mathrm{in}$. diameter $\times 32 \mathrm{in}$. deep. The internal configuration is determined by the type of fuel elements being shipped as follows:

(1) For HFIR fuel elements - a removable post consisting of aluminum wrapped with cadmium is centered in the cavity. The fuel assembly (1 inner element and 1 outer element) is positioned in the cavity by a concentric fuel basket fabricated of stainless steel clad cadmium.

(11) For ORR (Oak Ridge Research Reactor) type fuel elements which also include BSR (Bulk Shlelding Reactor) fuel elements, for PRR (Puerto Rico Research Reactor) fuel elements, and for $\mathrm{CP}-5$ (Chicago P1le No. 5) fuel assemblies - the fuel elements are positioned in the cavity by a magazine fabricated of stainless steel clad cadmium. The primary $99_{\text {Mo tar- }}$ get capsules will be positioned in the same magazine. Adapters will be utilized to hold the capsules in the magazine. The center post is removed

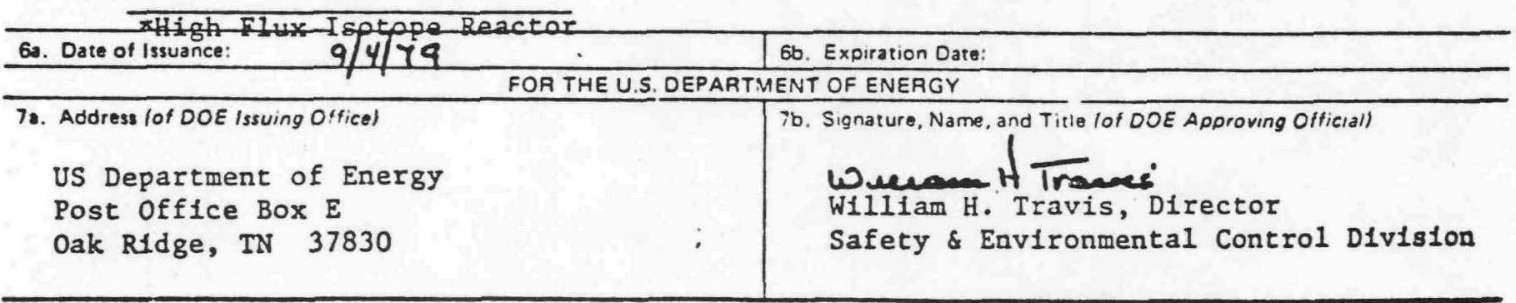


Page 2 - Cert1ficate of Compliance, No. USA/5507/BLF (DOE-OR), Revision 7

3. (2) (Continued)

b. Memorandum from R. M. Moser to William H. Travis, December 30, 1975.

c. Memorandum from R. M. Moser to William H. Travis, October 27, 1976.

d. Letter from M. E. Ramsey to J. A. Lenhard, July 26, 1979.

5. (Continued)

(11i) For PRNC (Puerto Rico Nuclear Center) TRIGA/FLIP type fuel ; assemblies - the fuel assemblies are positioned in the cavity by a steel, aluminum and elastomer basket. The center post is removed.

Shielding consists of a nominal $83 / 4 \mathrm{in}$. thickness of lead between $1 / 2$ Inch thick stainless steel inner and outer liners. Overall dimensions are $463 / 8$ in. diameter $x 721 / 2$ in. high. Access to the cavity is through a top plug having $14-11 / 2$ in. alloy steel studs. The gross welght is 23,000 ib.

(3) Drawings:

The cask and modifications are described in Oak Ridge National Laboratory Drawings: $M-10191-E L-001-D$ through $-006-D,-007-C$, and $-008-D$ through 012-D.

The PRNC TRIGA/FLIP fuel basket is described in Argonne National Laboratory Drawing No.: W-0170-0090-DE-00.

(b) Contents:

(1) Type and Form of Material

Solid, large quantity of radioactive materfals, fissile encased in metal cladding as irradiated fuel elements $O R$ as irradiated primary 9Mo target capsules.

(2) Maximum quantity of fissile material per package

(1) One HFIR frradiated fuel assembly containing up to $9,500 \mathrm{~g}$ of $235 \mathrm{U}$ as uranium oxide at a ${ }^{235} \mathrm{U}$ enrichment up to $93 \%$.

(11) Seventeen ORR-type irradiated fuel elements each containing up to $265 \mathrm{~g}$ of $235 \mathrm{U}$ as uranium-aluminum alloy at a ${ }^{235 \mathrm{U}}$ enrichment up to $93 \%$ for a maximum $235 \mathrm{U}$ content of $4.505 \mathrm{~g}$. 
II.B. 64

Page 3 - Certificate of Compliance, No. USA/5507/BLF (DOE-OR), Revision 7

(111) Seventeen 1rradiated PRR fuel elements each containing up to $192 \mathrm{~g}$ of $235 \mathrm{U}$ as uranium oxide as a $235 \mathrm{U}$ enrichment up to $20 \%$ for a maximum $235 \mathrm{U}$ content of $3,264 \mathrm{~g}$.

(iv) Seventeen irradiated ANL-CP-5 fuel assemblies each containing up to 170 grams of $235 \mathrm{U}$ as uranium-aluminum alloy at a $235 \mathrm{U}$ enrichment up to $93 \%$ for a maximum $235 \mathrm{U}$ content of 2,890 grams.

(v) Forty-eight PRNC TRIGA/FLIP irradiated fuel assemblies, cooled for at least 30 days, each containing up to 125 grams $235 \mathrm{U}$ as a uranium-zirconium hydride mixture, with a $235 \mathrm{U}$ enrichment of $70 \%$, for a maximum $235 \mathrm{U}$ content of 6,000 grams.

(v1) Four Irradiated primary 990 target capsules, cooled for e1ght hours after an irradiation period of less than 30 days, each containing up to 20 grams of $235 \mathrm{U}$ at $93 \%{ }^{235} \mathrm{U}$ enrichment, for a maximum $235_{U}$ content of 80 grams.

The heat load is $\leq 3.75 \mathrm{kw}$.

(c) Fissile Class 
II.B. 65

\section{B. RADIOACTIVE SOLIDS}

ORNL LOOP TRANSPORT CASK 
Photo $0876-72$

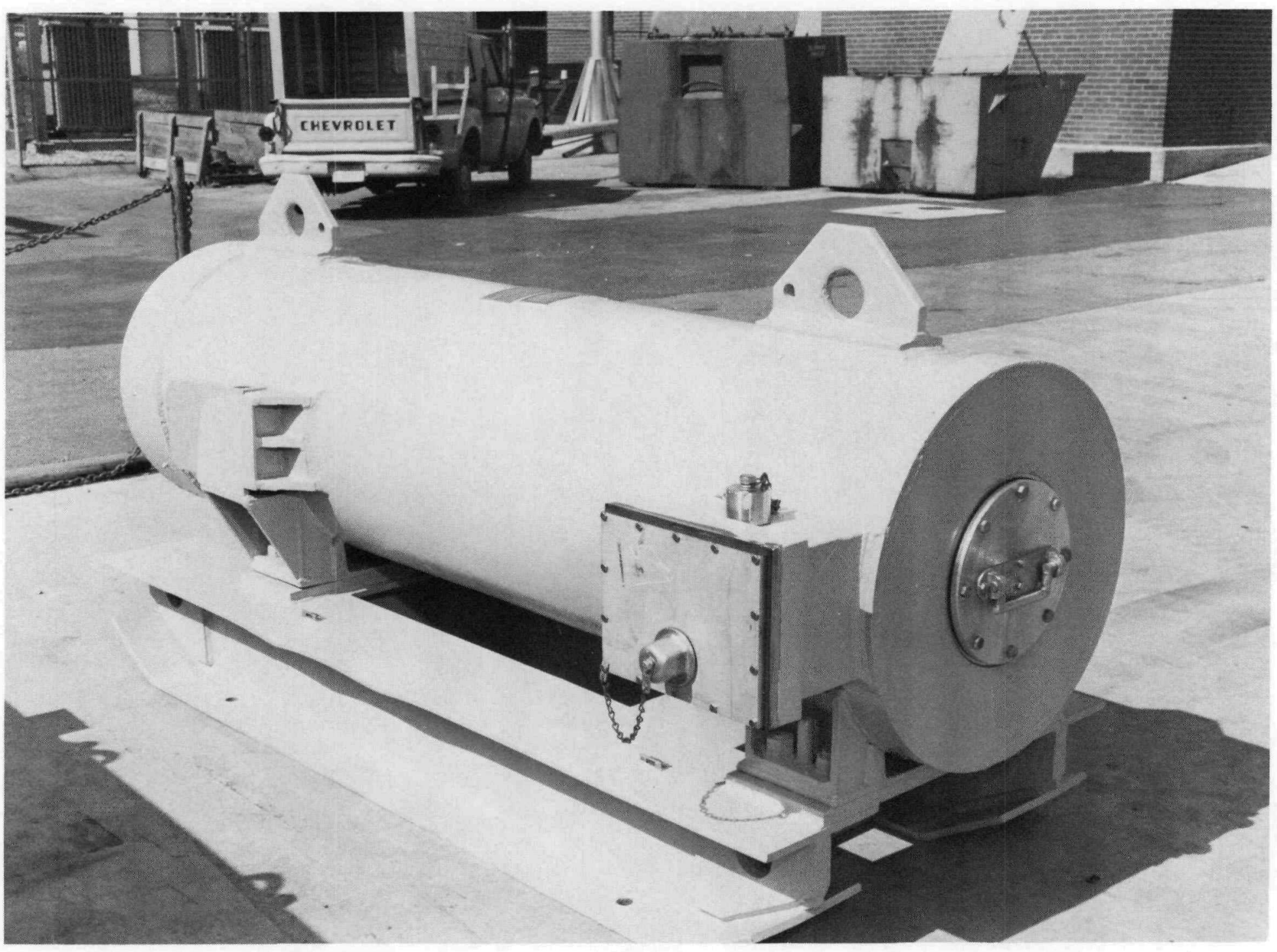

ORNL Loop Transport Cask - Type B 
ORNL DWG 75-500

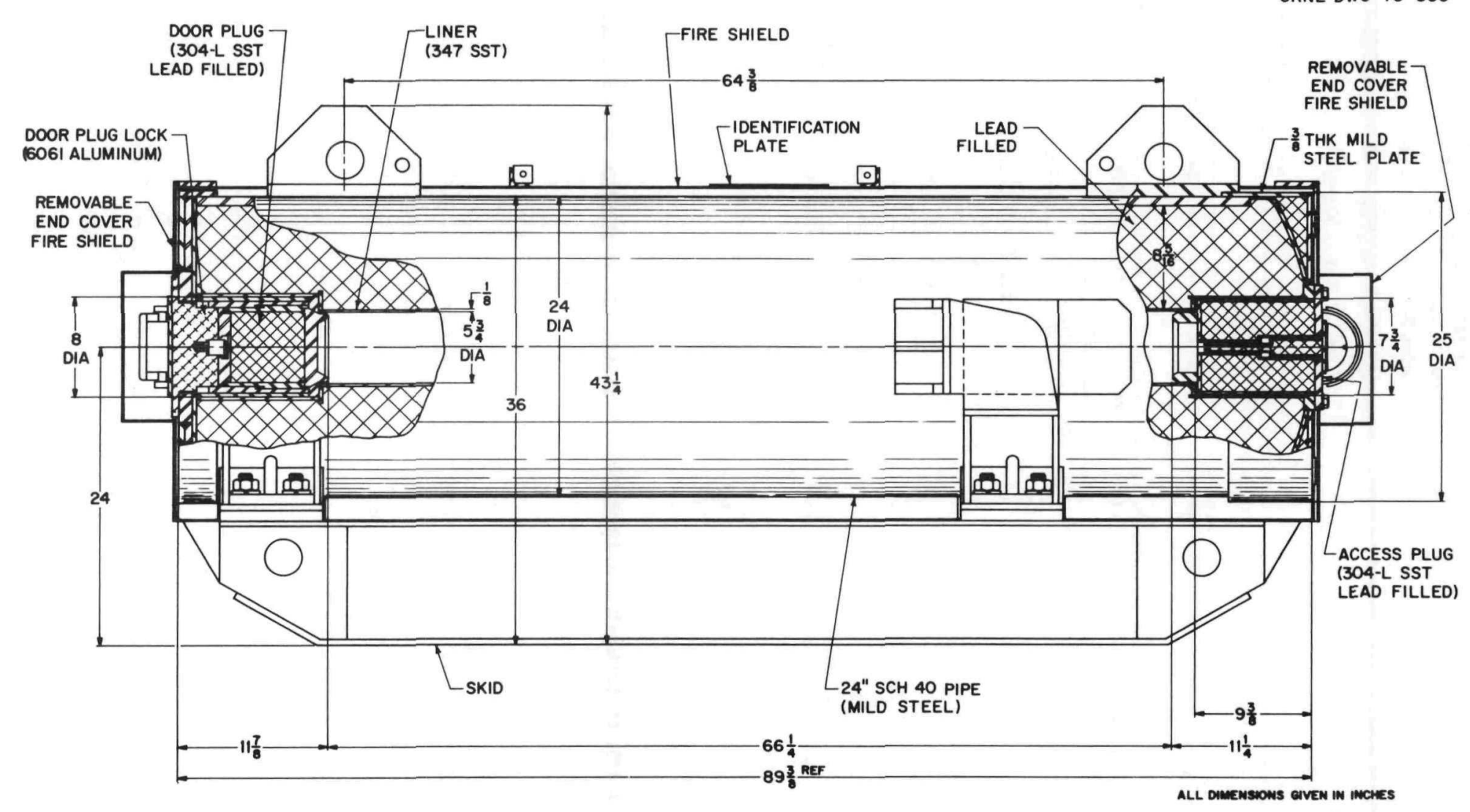

ORNL Loop Transport Cask - Type B 


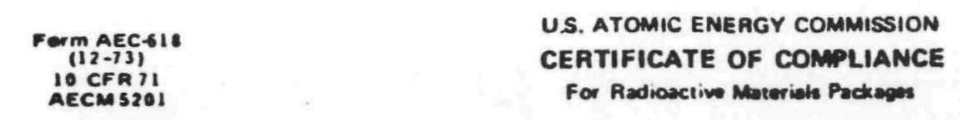

\begin{tabular}{|c|c|c|c|c|}
\hline $\begin{array}{l}\text { 1. Cortificate Number } \\
5753\end{array}$ & 16. Revision No. & $\begin{array}{l}\text { 1c. Package Identification No. } \\
\text { USA/5753/BLF (DOE-OR) }\end{array}$ & 1d. Page No. & $\begin{array}{l}\text { 16. Total No. Pagmes } \\
2\end{array}$ \\
\hline
\end{tabular}

PREAMBLE

2a. This certificate is issued to satisfy Sections 173.3939, 173.394, 173.395, and 173.396 of the Depertment of Transportation Hazardous Materials Regulations (49 CFR 170-189 and 14 CFR 103) and Sections 146-19-10a and 146-19-100 of the Depertmeme of Tramportation Dangerous Cargoes Regulations (46 CFR 146-149), as amended.

2b. The packaging and contents described in item 5 below, meets the safety standards set forth in Subpert C of Title 10, Code of Federel Regulations, Part 71, "Packaging of Radiosctive Material for Transport and Transportation of Radiosctive Material Under Certain Conditions."

2c. This certificate does not relieve the consignor from compliance with any requirement of the regulations of the US. Depertment of Transportation or other applicable regulatory agencies, including the gover nmemt of any country through or into which the packege will be tramported.

3. This certificate is issued on the besis of a safery anelysis report of the peckepe design or application-

(1) Prepered by (Nome and addresa):

Oak Ridge National Laboratory

Post Office Box X

Oak Ridge, Tennessee 37830

(2) Title and Identification of report or application:

(3) Dote:

Safety Analysis Report for Packagtris

November 1977 ORNL Loop Transport Cask

Report No.: ORNL/ENG/TM-11

4. CONDITIONS

This certificate is conditional upan the fulfilling of the requirements of Subpart D of 10 CFR 71, as applicable, and the conditions specified in item 5 below.

5. Description of Packaging and Authorized Contents, Model Number, Fissile Class, Other Conditions, and Refierencus:

(a) Packaging:

(1) Model No.: ORNL Loop Transport Cask

(2) Description:

Packaging for Irradiated experimental capsules and spent fuel elements. Containment consists of the cladding or fackets of fuel elements or capsules or an inner contalner meeting DOT Specification $2 R$ or special form. The inner cavity is $53 / 4 \mathrm{in}$. diameter $x 68 \mathrm{in}$. 1ong. The outside dimensions are $24 \mathrm{in}$. diameter $\times 893 / 8 \mathrm{in.} \mathrm{1ong.} \mathrm{Shielding} \mathrm{consists}$ of a minimum thickness of $85 / 16 \mathrm{in}$. lead with a $1 / 8 \mathrm{in}$. thick inner stainless steel liner and an outer shell consisting of a 24 in. schedule 40 carbon steel pipe. Access to the cavity is through:

(i) A sliding door having $81 / 2$ in. closure bolts.

(ii) A plug on the opposite end having $81 / 2$ in. closure bolts.

Each opening is gasketed with a neoprene gasket. The gross weight of the cask is $16,150 \mathrm{lb}$. The skid weight is about $1000 \mathrm{lb}$.

\begin{tabular}{l|l}
\hline 6a. Date of Issuance: October 17, 1977 & 6b. Expiration Date: \\
\hline \multicolumn{2}{|c|}{ FOR THE U.S. ATOMIC ENERGY COMMISSION } \\
\hline 7a. Address of Issuing Office: & 7b. Signature, Name, and Title of Approving Officis/s \\
$\begin{array}{l}\text { Wepartment of Energy } \\
\text { Post Office Box E }\end{array}$ & $\begin{array}{l}\text { William H. Travis, Director } \\
\text { Safety \& Environmental Control Division } \\
\text { Oak Ridge, Tennessee 37830 }\end{array}$ \\
\hline
\end{tabular}


Page 2 - Certificate of Compliance, No. USA/5753/BLF (DOE-OR), Revision 1

(2) Description (continued)

A fire shield consisting of $30 \mathrm{in.}$ diameter mild steel cover $1 / 8 \mathrm{in}$. thick and painted with intumescent paint surrounds the cask.

(3) Drawings:

The cask was constructed and modified in accordance with ORNL Drawings M-11109-EL-008-D through -013-D, -020-E, and -021-D.

(b) Contents:

(1) Type and Form of Material

Solid, large quantity of radioactive materials, fissile and non-fissile, increased in metal cladding, meeting special form or packaged in DOT Specification $2 R$ inner container and whose decay heat load does not exceed 450 watts when shipped by Common Carrier. When shipped by exclusive use vehicle, the decay heat will not exceed 1,000 watts.

(2) Maximum Quantity of Material per Package

Fissile material is limited to $1250 \mathrm{~g}$. per shipment; however, if the total quantity of fissile naterial exceeds $800 \mathrm{~g}$. , the distribution of fissile material is further limited to 200g. per linear $\mathrm{ft}$.

(c) Pissile Class 
0

-

○ 
II.B. 71

B. RADIOACTIVE SOLIDS

HFIR UNIRRADIATED FUEL ELEMENT CASK (Outer) 
II.B. 72

ORNL Photo $2375-78$

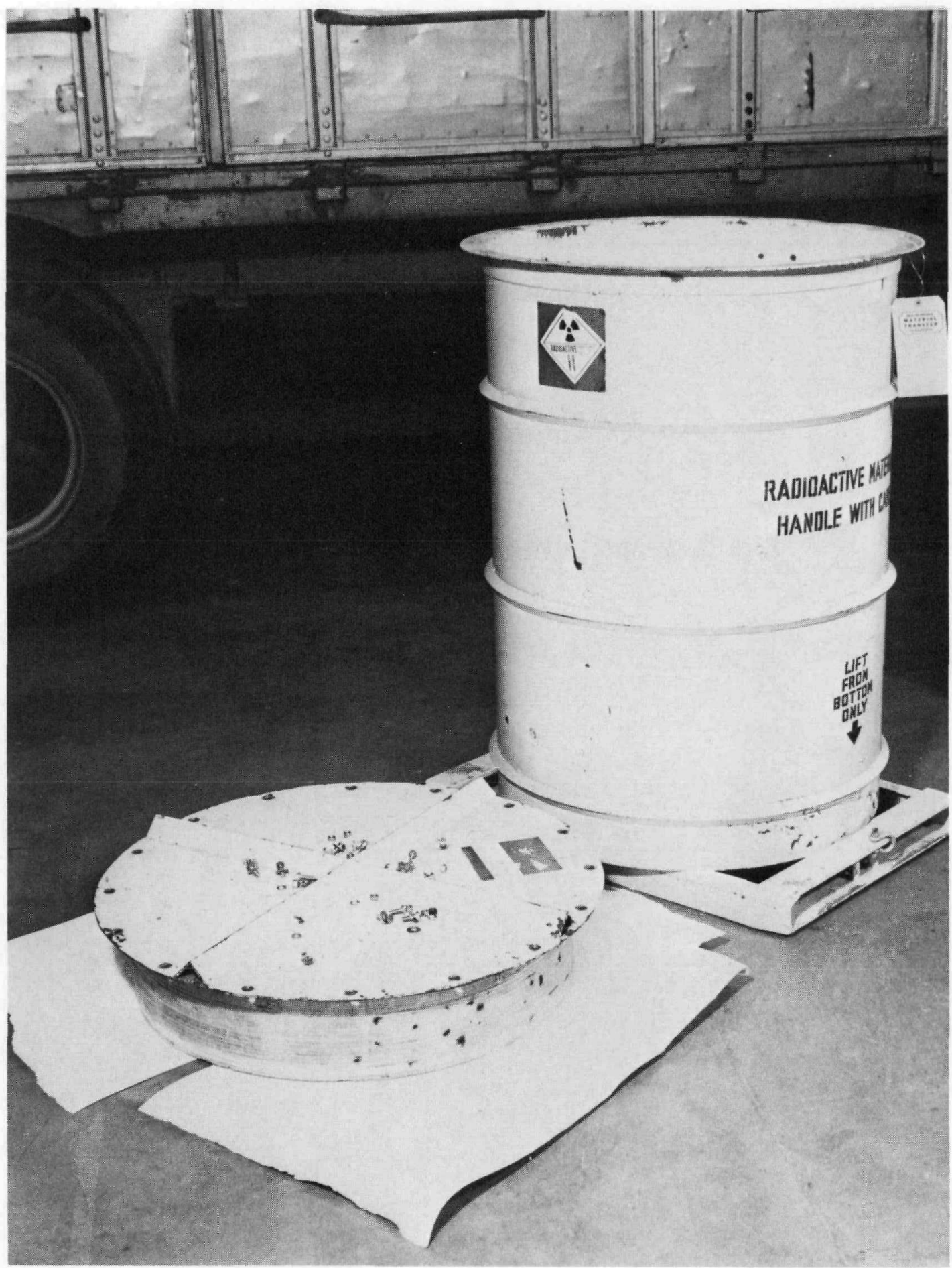

ORNL HFIR Unirradiated Fuel Element Shipping Container (Outer) Type B 


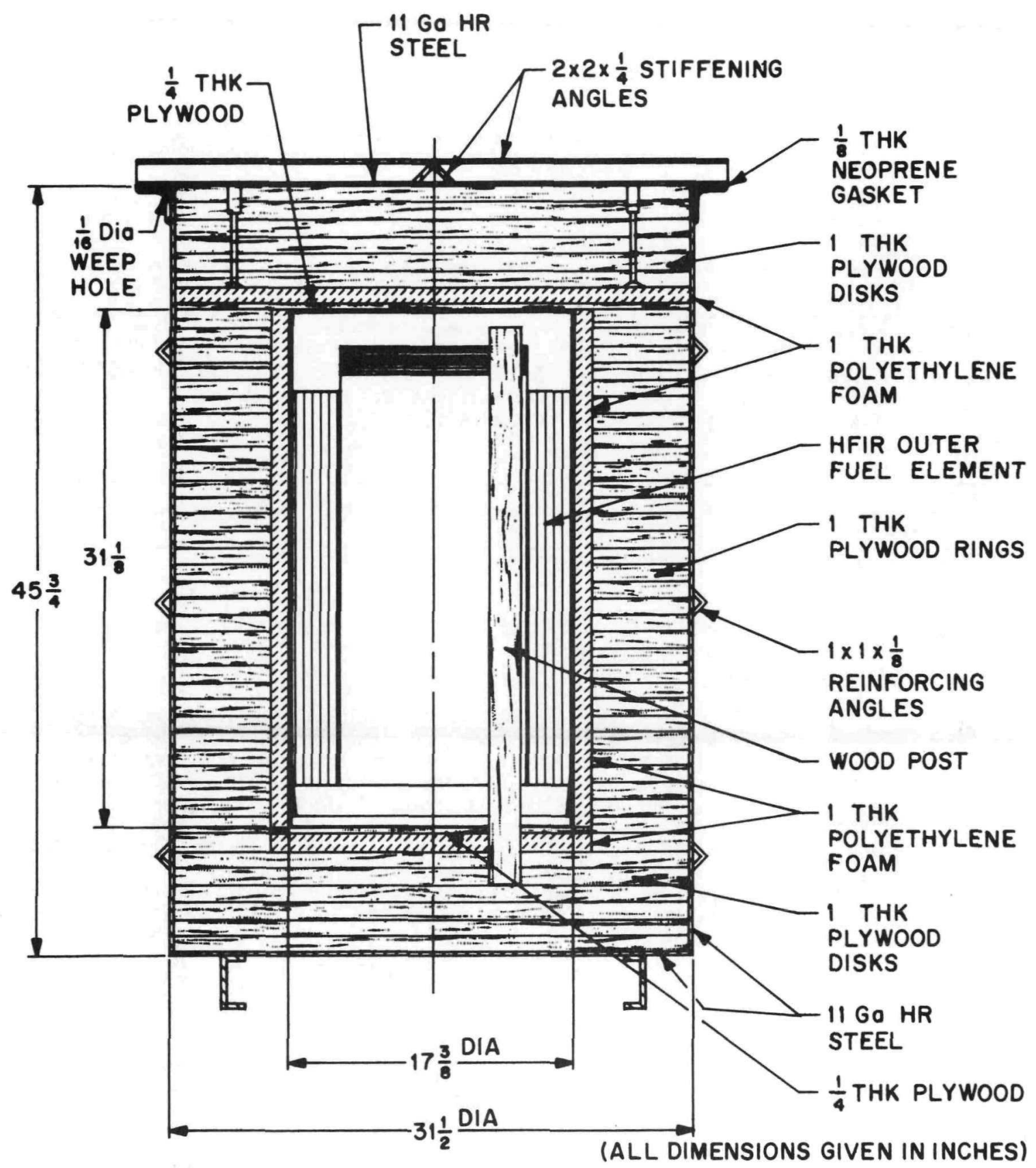

ORNL HFIR Unirradiated Fuel Element Shipping Container (Outer) Type B 


\begin{tabular}{|c|c|}
\hline 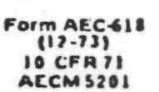 & $\begin{array}{l}\text { U.S. ATOMIC ENERGY COMMISSION } \\
\text { CERTIFICATE OF COMPLIANCE } \\
\text { For Radioseline Moterists Packapes }\end{array}$ \\
\hline
\end{tabular}

\begin{tabular}{|c|c|c|c|c|c|}
\hline \multicolumn{2}{|c|}{$\begin{array}{l}\text { 1a. Certificsile Number } \\
5797-A\end{array}$} & $\begin{array}{l}\text { 1b. Revision No. } \\
1\end{array}$ & $\begin{array}{l}\text { Ic. Package Idontification No. } \\
\text { USA/5797-A/BF (ERDA-OR) }\end{array}$ & 1d. Page No. & $\begin{array}{c}\text { 18. Total No. Past } \\
2 \\
\end{array}$ \\
\hline \multicolumn{6}{|c|}{ 2. PREAMBLE } \\
\hline 20. & \multicolumn{5}{|c|}{ 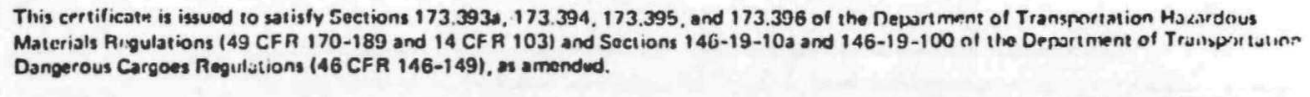 } \\
\hline 2b. & \multicolumn{5}{|c|}{$\begin{array}{l}\text { The packaging and contents described in item } 5 \text { below, moets the safoety standards set forth in Subpart C of Title 10, Code of Firdera" } \\
\text { Regulations, Purt 71, "Pockaging of Radioactive Matorial for Transpont and Tramsportation of Radioactive Material Uinder Certain } \\
\text { Conditions." }\end{array}$} \\
\hline $2 c$. & \multicolumn{5}{|c|}{ 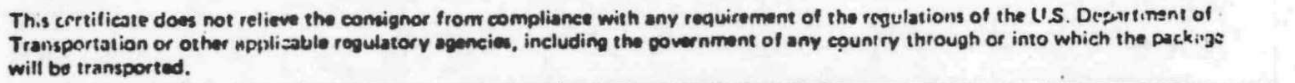 } \\
\hline
\end{tabular}

3. This certificate is issual on the basis of a sofety analyvis report of the packoge design or application-

(1) Prepared Ly (Nouns and address):

Oak Ricige l'ational Laboratory Post Office Box $X$

Oak Ridg:. Tennessee 37830

(2) Title and Identification of report or applicasion:

(3) liate:

Safety Ana? ysis for the ORNL. HFIR November 1977 Unirradiated Fuel Element Shipping Containers

Report No. ORNL/ENG/TM-9

4. contoitiotis

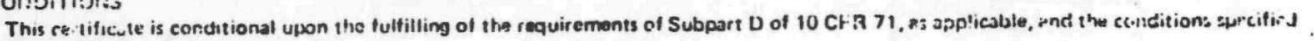
in item 5 below.

5. Descriptiuen of Packaging and Authorized Contents, Ktodel Nuniber, Fissile Class, Other Cunditions, and Reifrences:

(a) Packaging:

(1) Model: Outer HFIR* Unirradiated Fuel Element Shipping Coritainer

(2) Description:

Type B Packaging for unirradiated fissile radioactive material describer? as outer HFIR fuel element containing uranium enriched in the U-235

isotope. A 11 -gage carbon steel, right circular cylindrical container, $31.5 \mathrm{in}$. OD $\times 45.75 \mathrm{in.}$.long. The inner cavity is $177 / 8 \mathrm{in.}$. ID $\times 30 \mathrm{i} / 4$ inch long. A 2 in. OD wood post is located $41 / 2$ in. off center in the center cavity to prevent loading both an inner and outer clement. The space between the outer shell and the inner cavity is filled with laminated Douglas plywood to a minimum thickness of $6 \mathrm{in}$. The ply:tood is 1 ined with 1 in. thick polyethylene foam which serves as a shock absorier to protect the fuel element. Closure is provided by sixteen $3 / 8$ in. stee? bolts which attach the lid to a $2 \times 2 \times 1 / 8$ in. angle flange welded to the outer shel1. The package gross weight is $1050 \mathrm{lbs}$.

*High Flux Isotope Reactor

\begin{tabular}{|c|c|}
\hline 6. Date of Issuance: September 19, 1977 & 6b. Expiration Date: \\
\hline \multicolumn{2}{|c|}{ FOR THE U.S. ATOMIC ENERGY CONIMISSION } \\
\hline $\begin{array}{l}\text { 7. Address of Issuing Office: } \\
\text { U. S. Energy Research \& Development Adm. } \\
\text { Post Office Box E } \\
\text { Oak Ridge, Tennessee } 37830\end{array}$ & $\begin{array}{l}\text { 7b. Signature, Name, and Title of Approving Officiar: } \\
\text { Wereacen If Tavenesis } \\
\text { Hilliam H. Travis, Director } \\
\text { Safety \& Environmental Control Division }\end{array}$ \\
\hline
\end{tabular}


II.B. 75

Page 2 - Certificate of Compliance, No. 5797-A, Revision 1

(3) Dra!vings:

The package is described and fabricated in accordance with Oak Ridze National Laboratory Dratying H-20678-EL-003-D-2.

(b) Contents:

(1) Type and Form

Uraniuns as $U_{3} O_{8}$ - Al cermet, enriched to $33 \% U-235$ and clad in 10-riil thick aluminum as an outer IIFIR unirradiatied fte:1 element. Oak Ridge Hational Laboratory Draving [i-42126-6 describis the outer fuel elenient.

(2) Maximun quantity of uranium not to excec: Tyoe $B$ auantitios of radioactive waterial consisting of not iise than $6.8 \mathrm{~kg}$ of $\mathrm{U}-235$.

(c) Fissile Class: 
○

-

- 
II.B. 77

B. RADIOACTIVE SOLIDS

HFIR UNIRRADIATED FUEL ELEMENT CASK (Inner) 
II.B. 78

ORNL Photo 2374-78

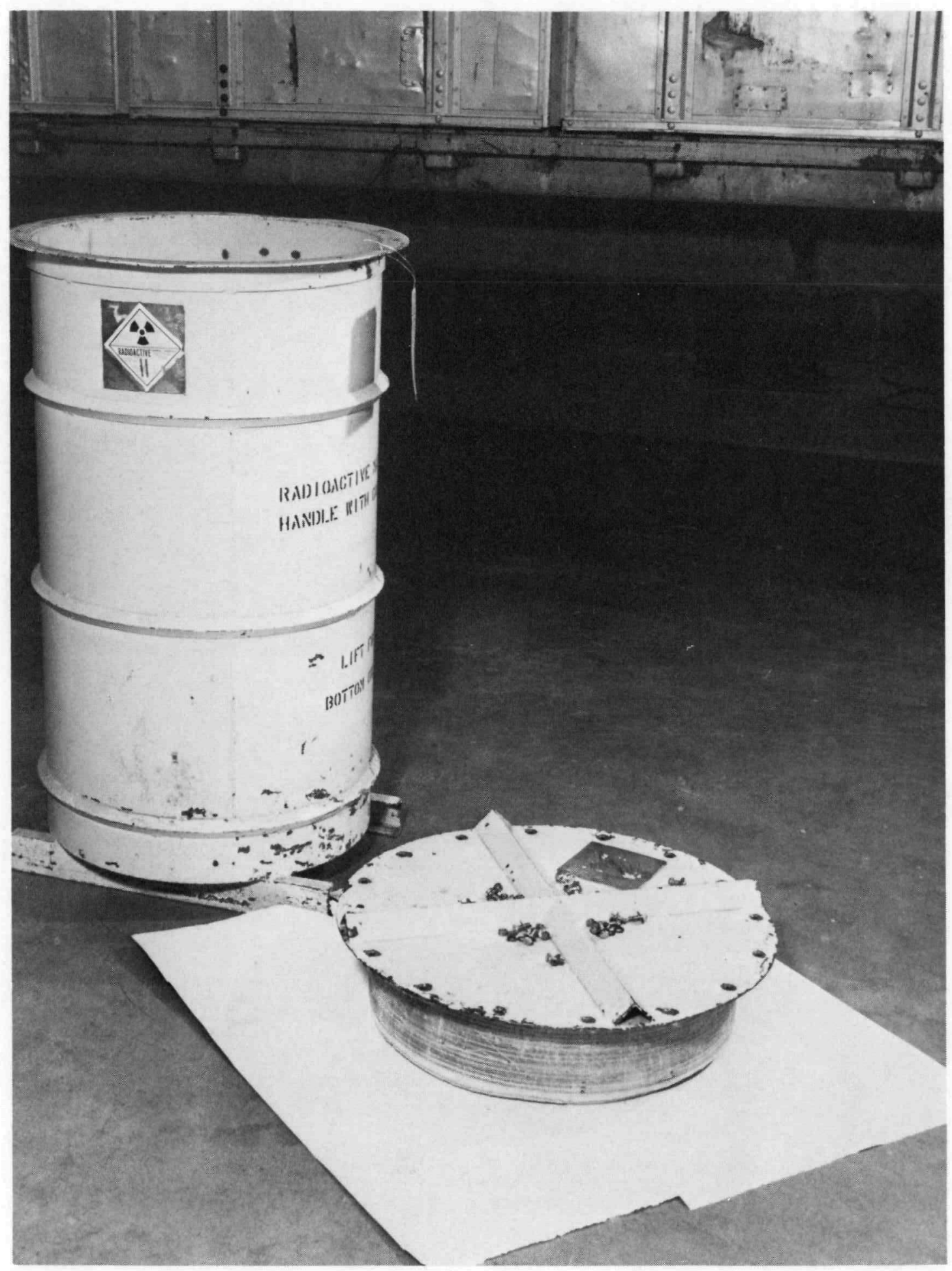

ORNL HFIR Unirradiated Fuel Element Cask (Inner) 
II.B. 79

ORNL DWG 74-9723

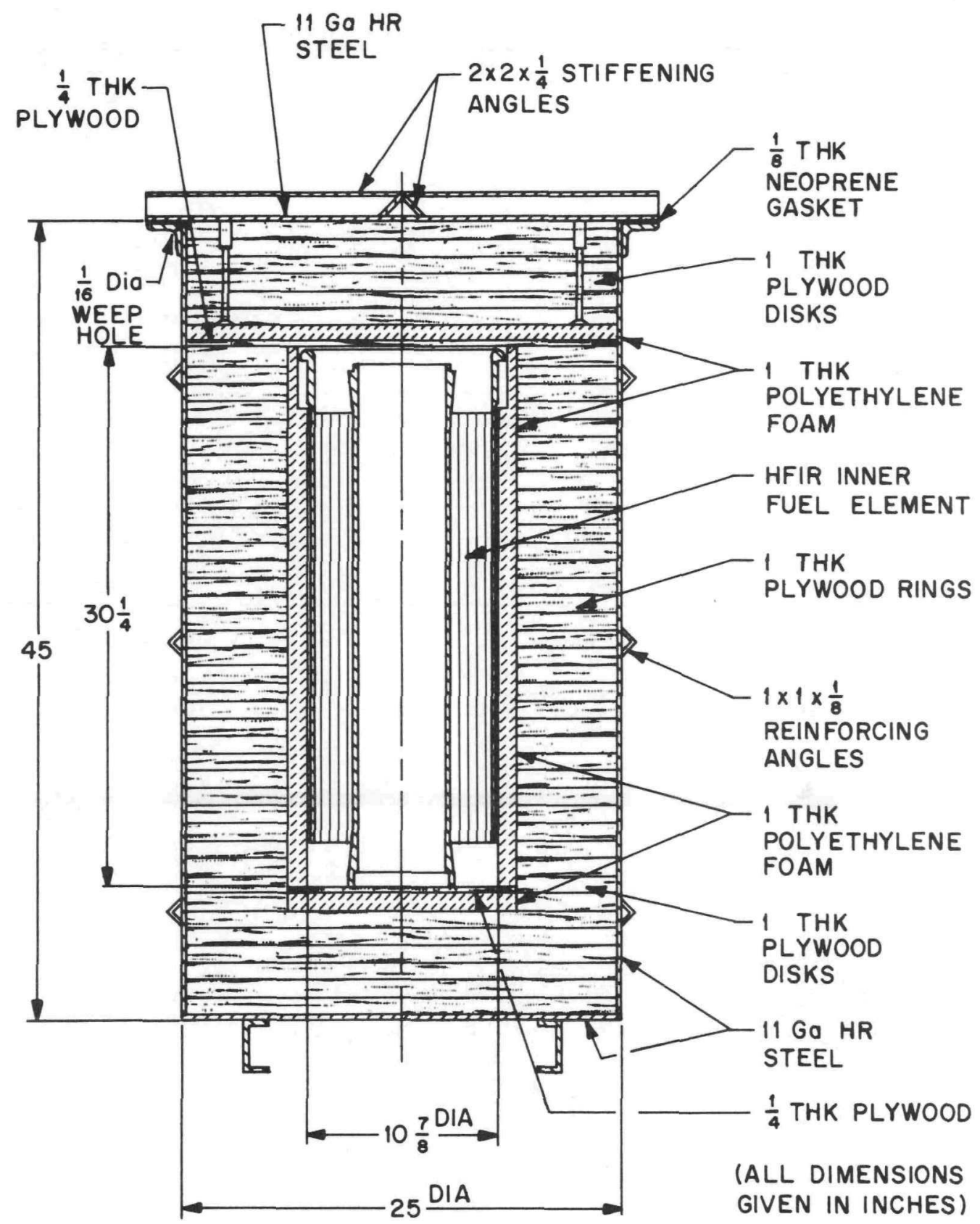

ORNL HFIR Unirradiated Fuel Element Cask (Inner) 
II.B. 80

NAC-618 U.S. NUCLEAR REGULATORY COMMISSION
CERTIFICATE OF COMPLIANCE
OCFR 71

For Radioactivo Materials Packages

\begin{tabular}{|c|c|c|c|c|}
\hline $\begin{array}{l}\text { 1.(a) Cortificate Number } \\
5797\end{array}$ & $\begin{array}{l}\text { 1.(b) Rovision No. } \\
0\end{array}$ & $\begin{array}{l}\text { 1.(c) Package Identification No. } \\
\text { USA/5797/AF }\end{array}$ & (1. (d) Pages No. & $\begin{array}{l}\text { 1.fel Total No. Pages } \\
3\end{array}$ \\
\hline
\end{tabular}

2. PREANBLE

2.13) This certificats is issued to satisfy Sections 173.393a, 173.394, 173.395, and 173.396 of the Department of Transportation Hazardous Ma:erals Fegulations 149 CFR 170.189 and 14 CFR 103) and Sections 146-19-10a and 146-19-100 of the Department of Transportation Dangerous Cargoos Regulations (46 CFA 146-149), as amended.

2.(b) The packaging and contents described in item 5 below, meets the salety standards set forth in Subpart C of Titto ro. Cade of Federal Regulations. Part 71, "Packaging of Radioactiva Materials for Transport and Transportation of Radiosctive Material Under Certsin Conditions."

2.Ic) This certificat does not relieve the consignor from compliance with any requirement of the regulations of the U.S. Department of Transportation or other apolicable regulatory agencies, including the government of any country through or into which the packzge will be transported.

3. This cersilicate is issued on the basis of a safety anaiysis report of the package design or application-

- 3.(a) Precared by (Name and address):

Department of Energy

P.O. BOx E

Oak Ridge, TiN 37830

3.(b) Title and identification of report or apolication:

Safety Analysis Report for Packaging: The ORNL HFIR Unirradiated Fuel Element Shipping Containers, ORNL/ENG/TM-9, November 1977, as amended.

3.(c) Docket No. 71-5797

4. CONDITIONS

This certiticase is conditional upon the fulfilling of the requirements of Subpart D of 10 CFR 71, as applicable, and the conditions specified

in it:m 5 balow.

5. Description of Packaging and Authorized Contents. Model Number. Fissile Class, Other Conditions, and References:

\section{(a) Packaging}

(1) Models Nos.: Inner HFIR Unirradiated Fuel Element Shipping Container, and Outer HFIR Unirradiated Fuel Element Shipping Container

(2) Description

Packaging for unirradiated fissile radioactive material as fuel e? ements for the High Flux Isotope Reactor (HFIR). The container is a right circular cylinder with an 11 -gauge carbon steel shell. Closure is provided by $16,3 / 8$-inch diameter steel bolts which attach the lid to the cylindrical steel shell. The steel shell is filled with laminated Douglas fir plywood with a minimum thickness of 6 inches. A central cavity is formed in the plywood, and lined with a 1-inch thickness of polyetheylene foam.

The packaging for the inner HFIR fuel element has overall dimensions of 25 -inch 0.0 . by 45 -inch high, a $10-7 / 8$-inch diameter by $30-1 / 4$-inch deep cavity, and a 660 pound gross weight.

The packaging for the outer HFIR fuel element has overall dimensions of 37.5-inch 0.0. x 45.75-inch high, a 17-3/8-inch diameter by 31-1/8-inch deep cavity, and a 1050 pound gross weight.

Revised 3/1/81 
- Certificate of Compliance No. 5797 - Revision No. 0, Docket No. 71-5797

j. (a) Packaging (Cont'd)

(3) Drawings

(i) The packaging for the inner HFIR fuel is constructed in accordance with Oak Ridge National Laboratory Drawing No. M-20978-EL-003, Rev 6.

(ii) The packaging for the outer HFIR fuel is constructed in accordance with Oak Ridge National Laboratory Drawing No. M-20978-EL-002, Rev. 6.

(b) Contents

(1) Type and form of material

Uranium as $\mathrm{U}_{3} \mathrm{O}_{8}-\mathrm{Al}$ cermet, enriched up to $93 \%$ in the $\mathrm{U}-235$ isotope, and clad in aluminum, 10-mils thick, and:

(i) For the packaging described in $5(a)(3)(i)$ the contents are described in Oak Ridge National Laboratory Drawing No. D-42118, Rev. J.

(ii) For the packaging described in $5(a)(3)(i i)$ the contents are described in Oak Ridge National Laboratory Drawing No. D-42126, Rev. G.

(2) Maximum quantity of material per package

(i) For the contents described in $5(b)(1)(i)$ not more than $2.6 \mathrm{~kg}$ of U-235.

(ii) For the contents described in $5(\mathrm{~b})(1)(\mathrm{ii})$ not more than $6.8 \mathrm{~kg}$ of U-235.

\section{(c) Fissile Class}

3. Prior to delivery to a carrier for transport, the shipper shall ensure that at no point along the proposed shipping route that the ambient temperature will be less than $32^{\circ} \mathrm{F}$; or, the shipmeric silall be mude in a heated vahicle such that the package temperature shall not be less than $32^{\circ} \mathrm{F}$ along the shipping route.

7. The package authorized by this certificate is hereby approved for use under general license provisions of 10 CFR $\S 71.12(b)$.

3. Expiration date: September 30, 1984. 
-

-

- 
II.B. 83

B. RADIOACTIVE SOLIDS

ORNL IN-PILE CAPSULE SHIPPING CASK 
ORNL Photo 0182-72

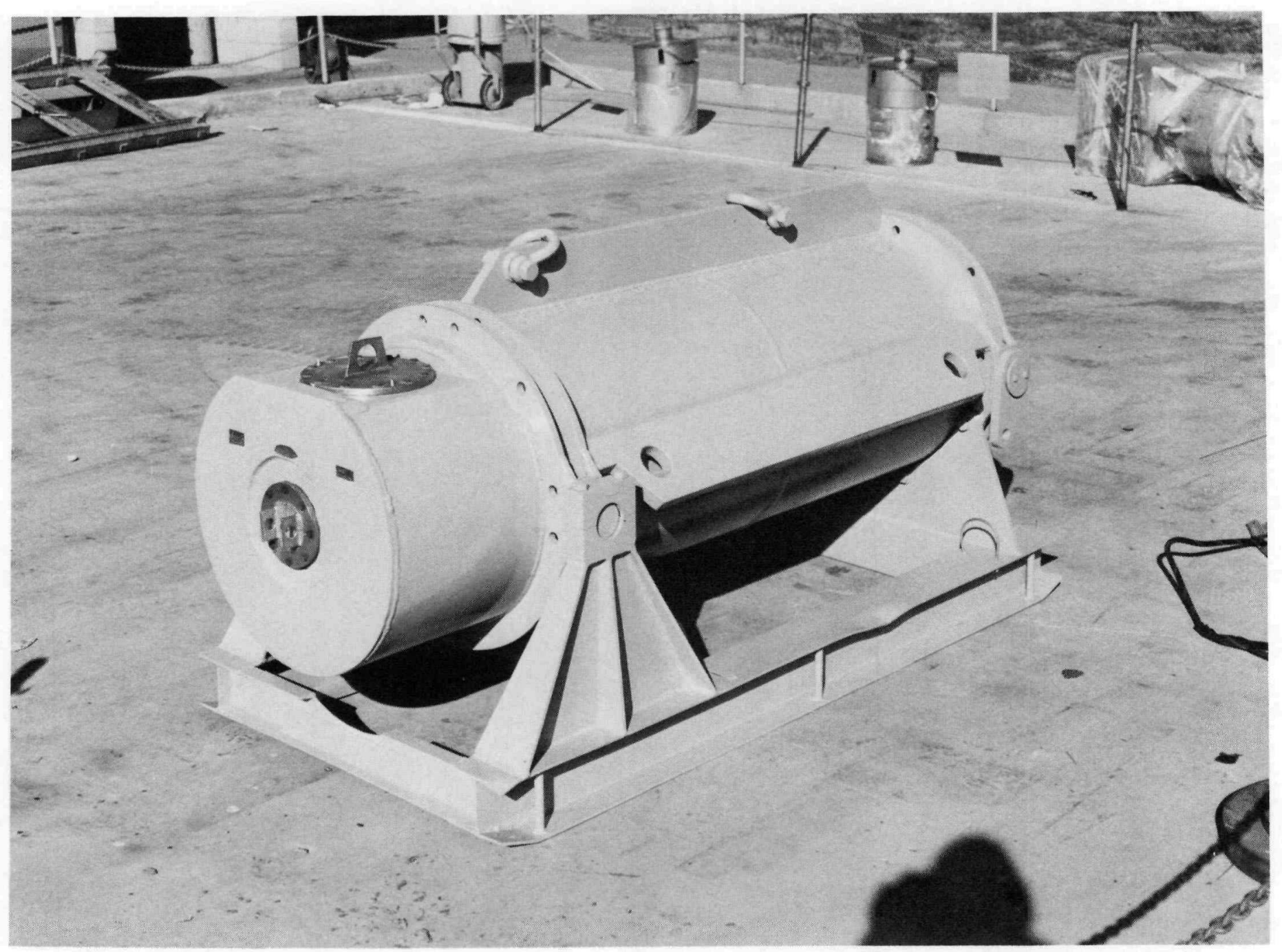

ORNL In-Pile Capsule Shipping Cask - Type B 


\begin{tabular}{|c|c|}
\hline $\begin{array}{l}\text { FormAEC-618 } \\
\text { (12-73) } \\
10 \text { CFR } \\
\text { AECM } 5201\end{array}$ & $\begin{array}{l}\text { US. ATOMIC ENERGY COMMISSION } \\
\text { CERTIFICATE OF COMPLIANCE } \\
\text { For Radionctive Materieds Packoger }\end{array}$ \\
\hline
\end{tabular}

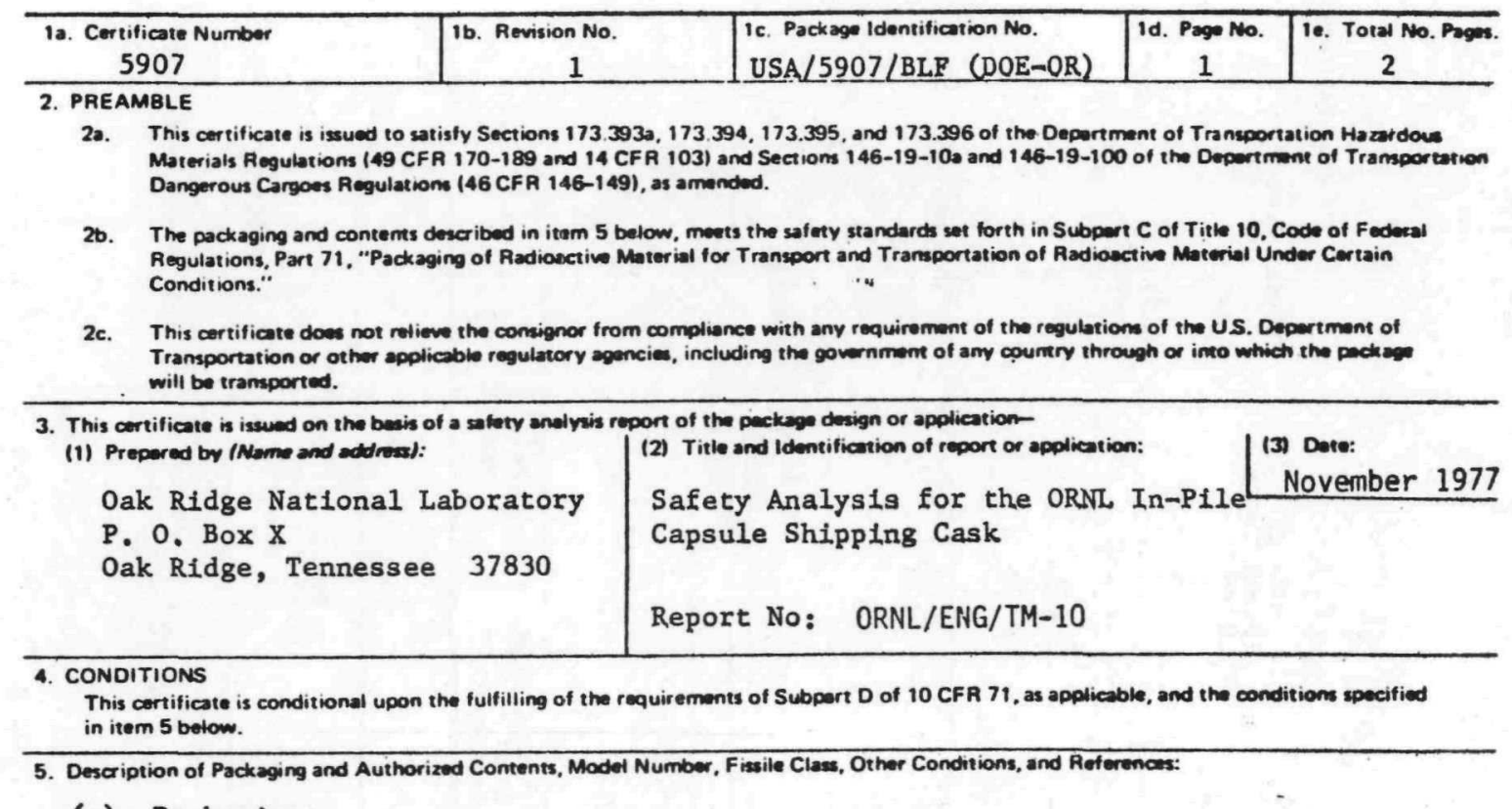

(a) Packaging:

(1) Model No.: ORNL In-Pile Capsule Shipping Cask.

(2) Description:

Packaging for irradiated experimental capsules and spent fuel elements. Containment consists of the cladding or jackets of fuel elements or capsules or an inner container meeting DOT Specification $2 R$ or spectal form. The inner cavity is $43 / 4$ in. I.D. $x 58$ in. long. The cask is $24 \mathrm{in.} \mathrm{O.D.} \times 83 \mathrm{in.}$ long. Shielding consists of $91 / 2 \mathrm{in.}$ of lead between a $1 / 8$ in. thick stainless steel inner liner and a $0.75 \mathrm{in.} \mathrm{total}$ thickness, carbon steel outer shell. Access to the cavity is through:

(i) A sliding gate having $12-3 / 8^{\prime \prime}$ dia. closure bolts.

(ii) A lower plug having $8-3 / 8^{\prime \prime}$ dia. closure bolts.

(iii) An upper plug having $8-1 / 2^{\prime \prime}$ dia. closure bolts.

Each opening is gasketed with a neoprene gasket. The cask gross weight is $17,000 \mathrm{lb}$. The skid weighs $1,000 \mathrm{lb}$.

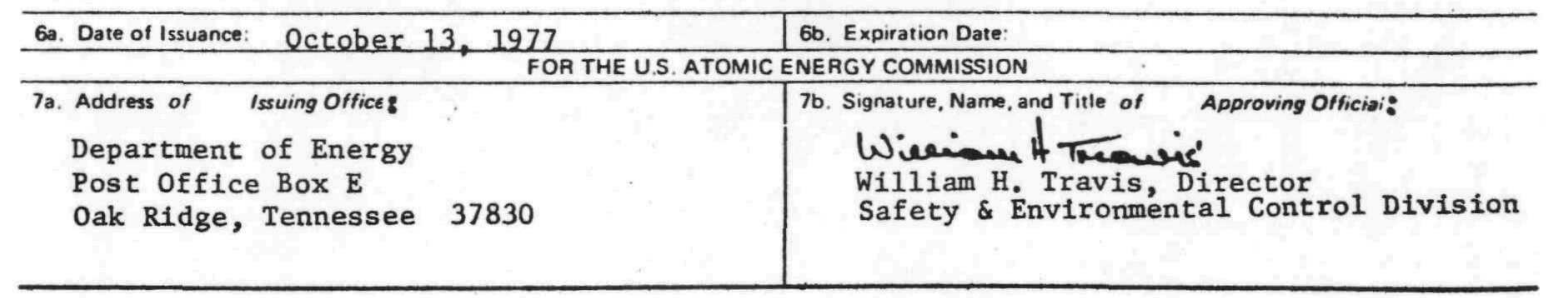


Page 2 - Certificate of Compliance, No. USA/5907/BLF (DOE-OR), Revision 1

\section{(3) Drawings:}

The cask was constructed in accordance with Pratt \& Whitney Drawing CLR-10572-12 and modified in accordance with Oak Ridge National Laboratory Drawings 11-11165-EL-001-D through -011-D.

(b) Contents:

(1) Type and Form of Haterial

Solid, large quantity of radioactive materials, fissile and non-fissile, encased in metal cladding, meeting special form or packaged in DOT Specification $2 R$ inner container and whose decay heat load does not exceed 350 watts when shlpped by common carrier. When shipped by exclusive use vehicle, the decay heat load will not exceed 1, oco watts.

(2) Maximum quantity of material per package

Fissile material is limited to $1250 \mathrm{~g}$ per shipment; however, if the total quantity of fissile material exceeds $800 \mathrm{~g}$, the distribution of fissile material is further limited to $250 \mathrm{~g}$ per linear foot.

(c) Fisstie Class 

II.B. 89

B. RADIOACTIVE SOLIDS

ORNL GARDEN CARRIER NO. 2 
II. B. 90

ORNL Photo 98436A

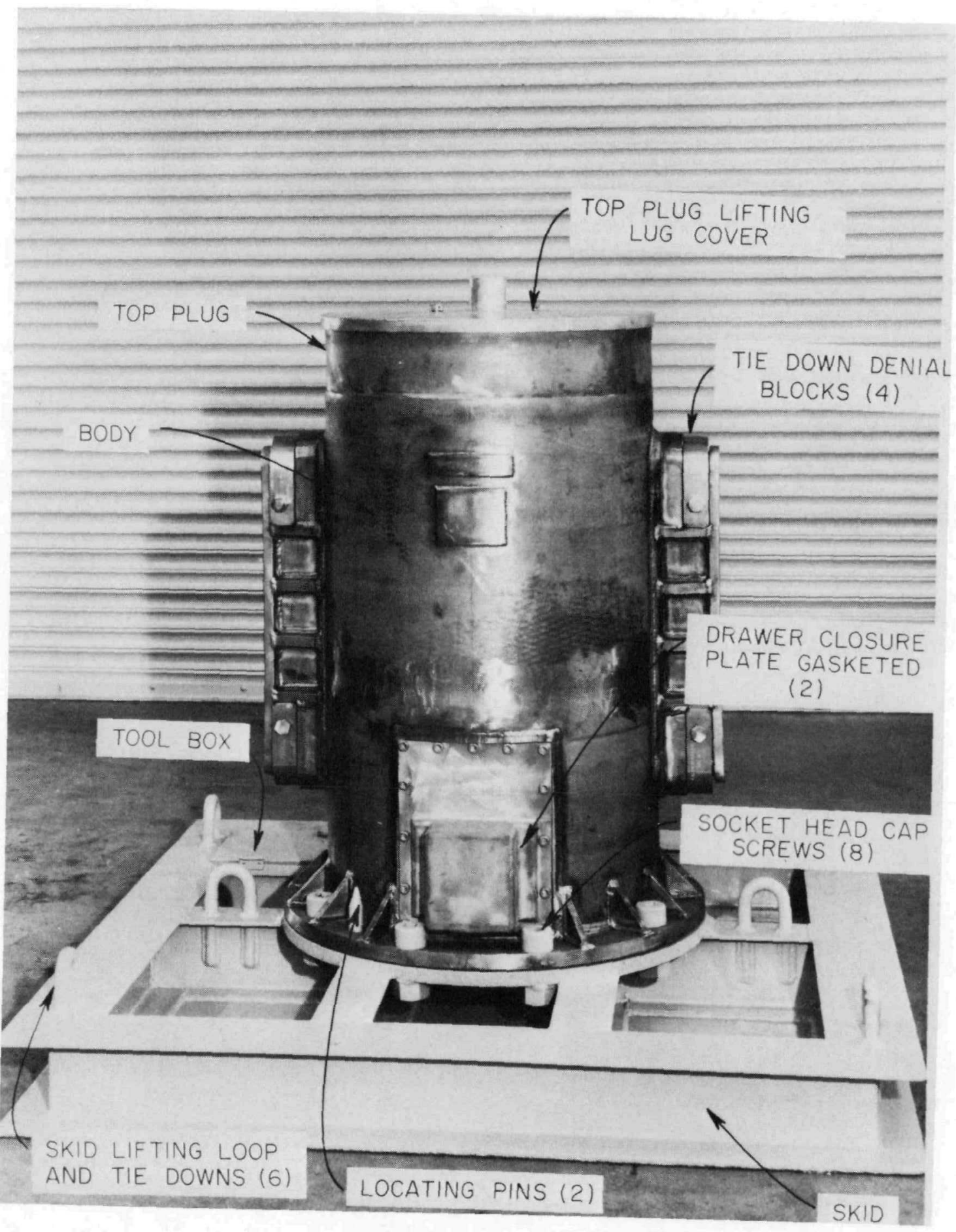

ORNL Garden Carrier No. 2

Type B 


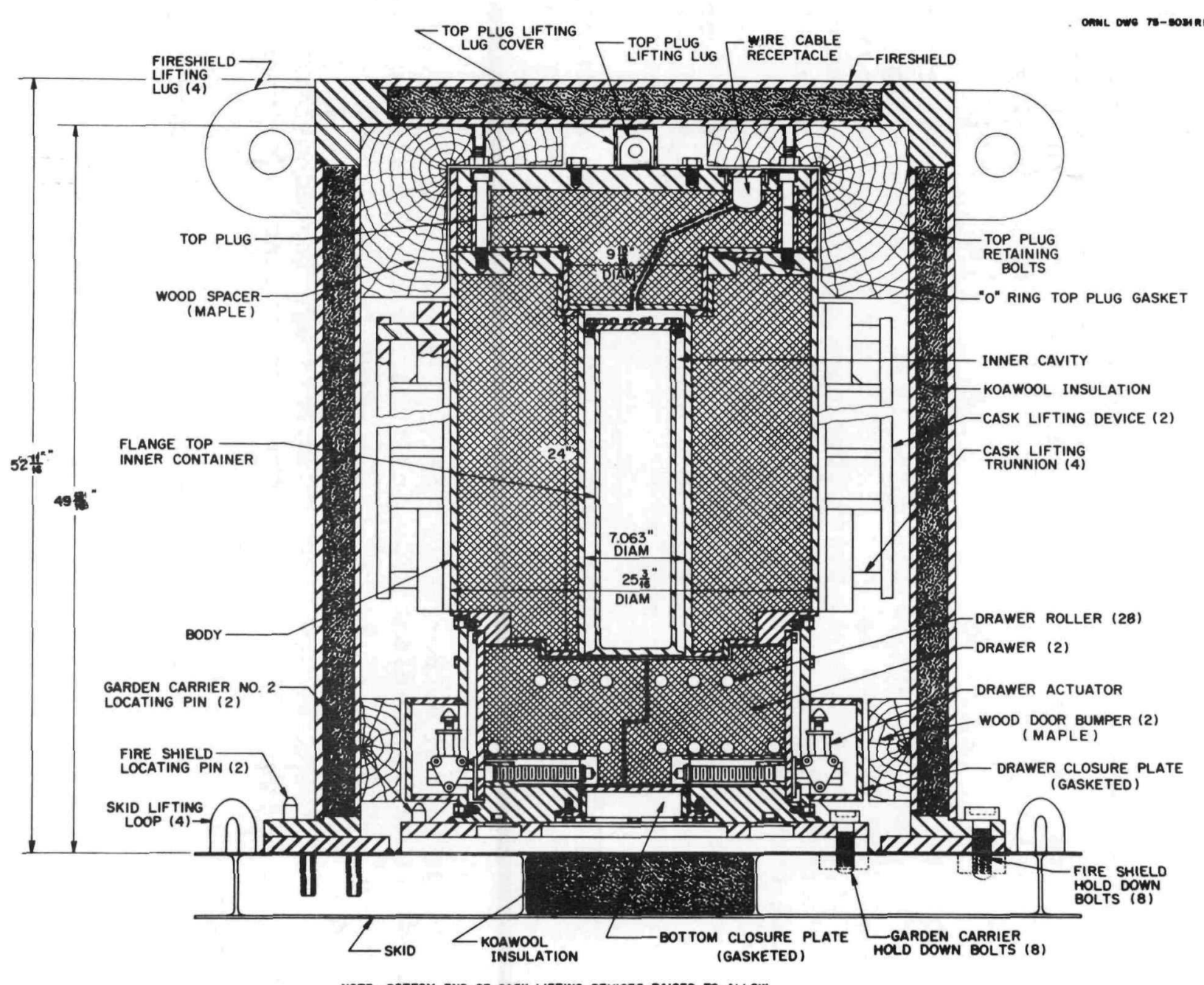

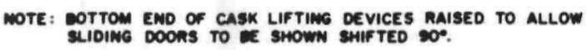

ORNL Garden Carrier No. 2 - Type B 


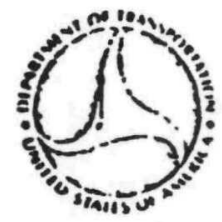

\author{
DEPARTMENT OF TRANSPORTATION \\ HAZARDOUS MATERIALS REGULATIONS EOARD \\ WASHINGTON, D.C. 20590
}

SPECIAL PERMIT NO. 6088

This special permit is issued pursuant to 49 CFR 170.15 of the Department of Transportation (DOT) Hazardous Materials Regulations, as amended, and on the basis of the August 11, 1969, petition by Oak Ridge National Laboratory, Oak Ridge, Tennessee.

1. Shipments of fissile and large quantities of radioactive materials, n.o.s., are hereby authorized in the packaging as described in this special permit. This packaging, when constructed and assembled as prescribed herein, with the contents as authorized herein meets the standards prescribed in the DOT regulations, Sections $173.395(c)(2), 173.396(c)(3)$, and 173 . $398(\mathrm{c})$. Shipments must be in accordance with the provisions of the U. S. Atomic Energy Commission (USAEC), Oak Ridge Operations Office approval number 69-014 dated August 4, 1969, and as further provided for herein.

2. Each shipper, under this permit, other than the petitioner named above, shall register his identity with this Board prior to his first shipment, and shall have a copy of this permit in his possession before making any shipment.

3. The packaging authorized by this permit consists of leadfilled, steel cask weldment, which is a right cylinder approximately $25^{\prime \prime}$ in diameter by $49^{\prime \prime}$ high, weighing about 8500 pounds, with a $7^{\prime \prime}$ diameter by $24^{\prime \prime}$ deep cavity. Approximately 8 . $3 / 16^{\prime \prime}$ of lead shielding is provided. Contents are loaded within DOT Specification $2 \mathrm{R}$ or equivalent inner containment. The package is identified as the Garden Carrier Number 2 Shipping Cask, and is described on Oak Ridge National Laboratory's drawing number M-12166-CD-037-D and in the attachment to the USAEC Certification.

4. The contents of each package authorized by this permit consist of fissile and large quantities of radioactive material n.o.s., in the form of unirradiated and irradiated fuel elements and contained sections of fuel elements with solid and liquid mixed fission products, or waste products. Liquids will be contained in primary polyethylene or stainless steel bottles within 
the DOT Specification $2 \mathrm{R}$ containment vessel. The maximum thermal decay energy of the contents is 100 watts. The fissile content is limited to not more than 500 grams of uranium-235, 350 grams of uranium-233 or plutonium, or 350 grams of any combination thereof.

5. The packaging authorized by this permit meets the requirements for shipment as Fissile Class I. The transport index must be assigned based on external radiation levels.

6. The outside of each package must be plainly and durably

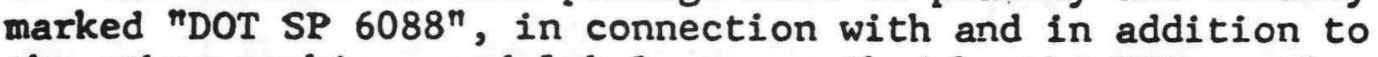
the other markings and labels prescribed by the DOT regulations. Each shipping paper issued in connection with shipments made under this permit must bear the notation "DOT SPECIAL PERMIT NO. 6088", in connection with the commodity description thereon.

7. Each package must have its gross weight plainly and durably marked on the outside of the package.

8. This permit authorizes shipments only by motor vehicle, and rail.

9. The shipper is required to furnish an experience report to this Board before expiration of the permit and when any amendment is requested. This report must include the approximate number of packages shipped, and the number of packages involved in any loss of contents. The modes of transportation used for these shipments must also be shown.

10. Prior to each shipment authorized by this permit, the shipper shall notify the consignee of the dates of shipment and expected arrival. The shipper shall notify each consignee of any special loading/unloading instructions prior to his first shipment.

11. Any incident involving loss of contents of the package must be reported to this Board at the earliest feasible moment following the incident. 
0

○

○ 
II.B. 95

B. RADIOACTIVE SOLIDS

ORNL URANIUM SHIELDED SHIPPING CASKS 
ORNL Photo 2289-78

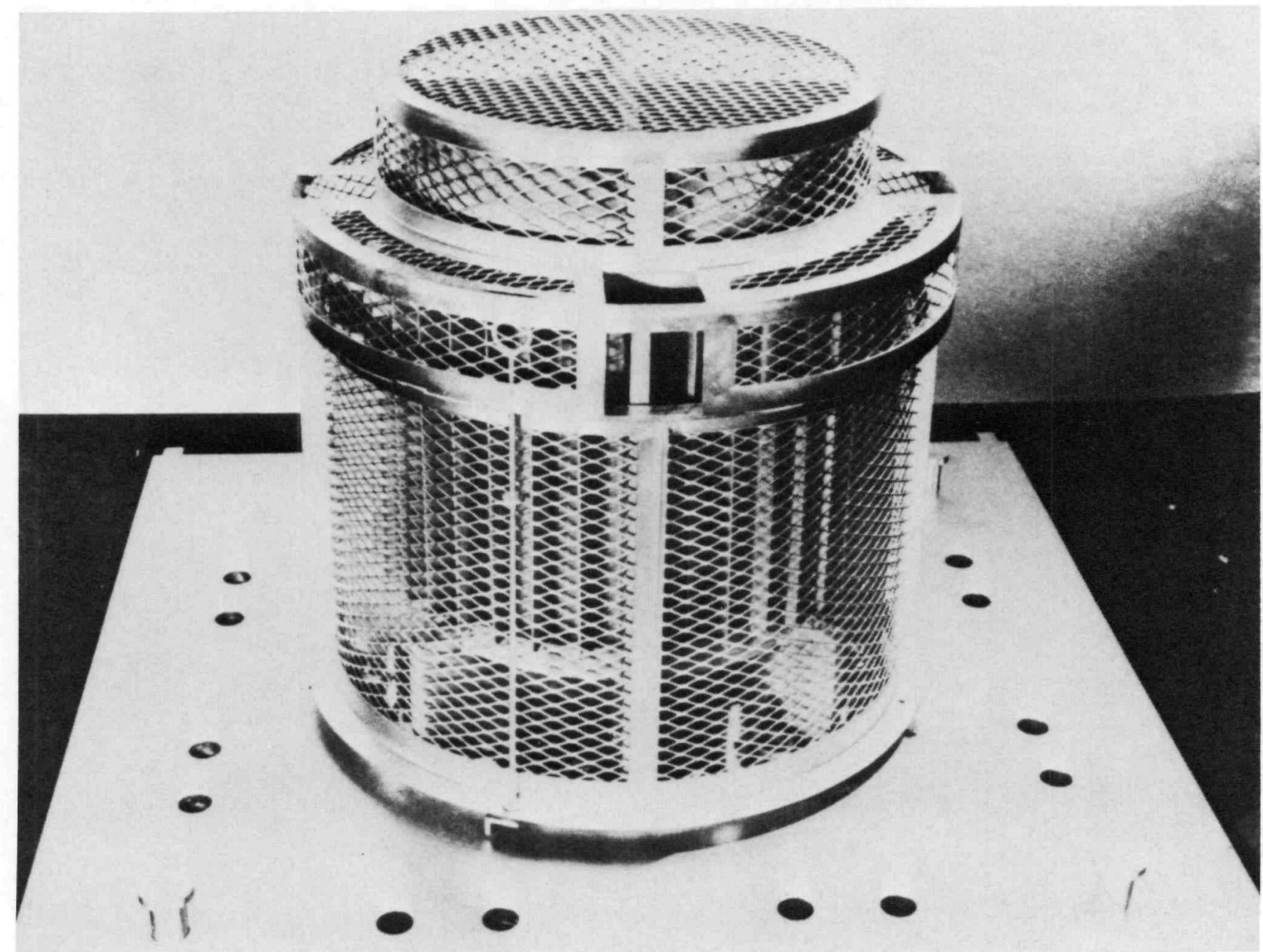

ORNL Uranium Shielded Shipping Cask - Type B 


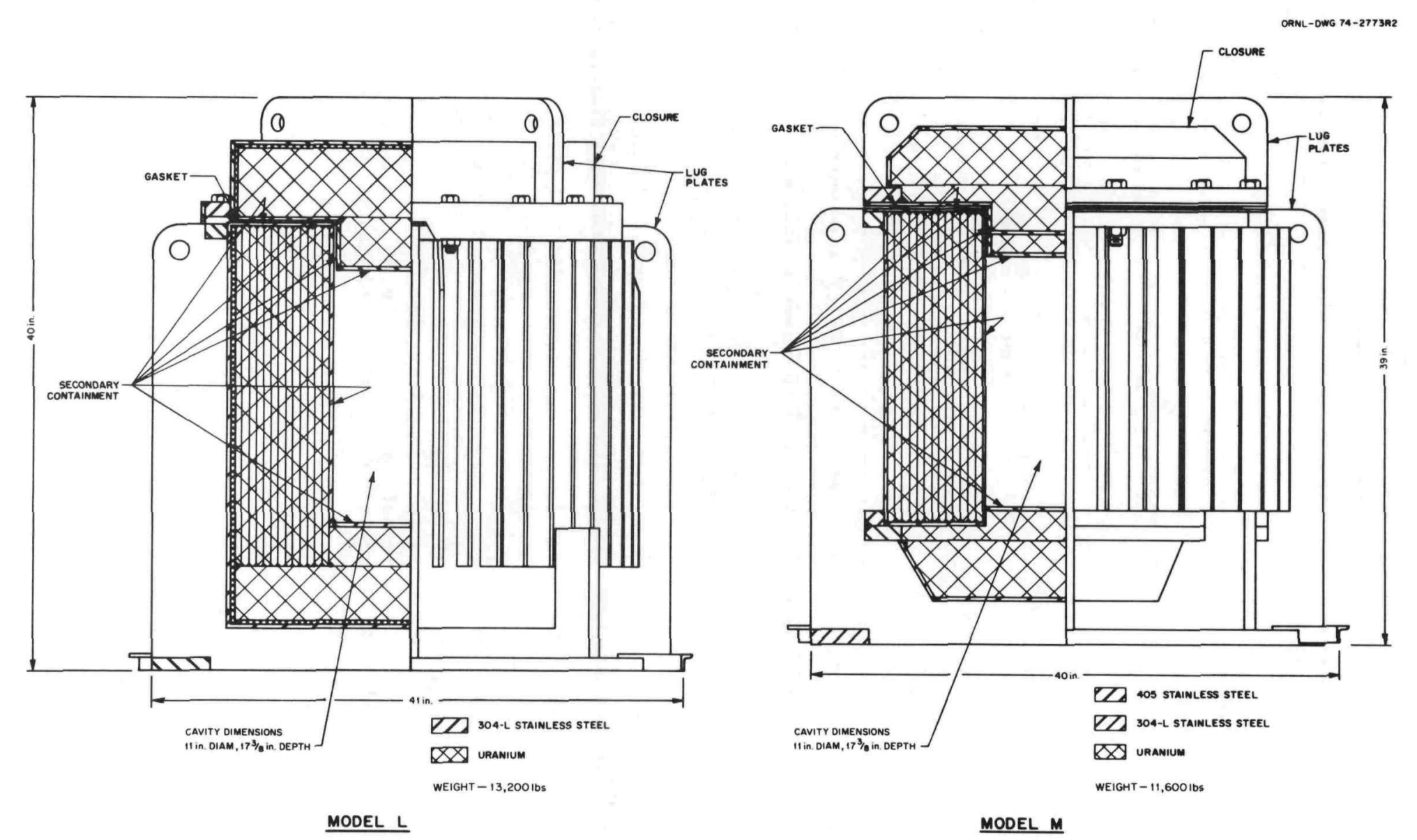

ORNL Uranium Shielded Shipping Cask - Type B 


US. ATOMIC ENEAGY COMMISSION
FormAECCS18
CERTIFICATE OF COMPLIANCE
10 CFR 71,
AECM 5201

\begin{tabular}{|c|c|c|c|c|c|}
\hline \multicolumn{2}{|c|}{$\begin{array}{l}\text { 1a. Certificate Number } \\
\text { USA/5595/BL (ERDA-OR) }\end{array}$} & $\begin{array}{l}\text { 1b. Revision No. } \\
1\end{array}$ & $\begin{array}{l}\text { 1c. Package Idemtification No. } \\
\text { USA/5595/BL (ERDA-OR) }\end{array}$ & $\begin{array}{l}\text { 1d. Pape No. } \\
1\end{array}$ & $\begin{array}{l}\text { 1e. Total No. Pages. } \\
2\end{array}$ \\
\hline \multicolumn{6}{|c|}{ 2. PREAMBLE } \\
\hline $2 a$. & \multicolumn{5}{|c|}{$\begin{array}{l}\text { This certificate is issued to satisfy Sections 173.393a, 173.394, } 173.395 \text {, and } 173.396 \text { of the Department of Transportation Hazardous } \\
\text { Materials Regulations (49 CFR 170-189 and 14 CFR 103) and Sections 146-19-10a and 146-19-100 of the Deppertmant of Tramportation } \\
\text { Dangerous Cargoes Regulations (46 CFR 146-149), as amended. }\end{array}$} \\
\hline $2 \mathbf{b}$. & \multicolumn{5}{|c|}{$\begin{array}{l}\text { The packaging and contents dencribed in item } 5 \text { below, meets the safety standarde set forth in Subpert C of Titie 10, Code of Federel } \\
\text { Regulations, Part 71, "Packaging of Radioactive Mater iel for Transport and Transportation of Radiactive Materiel Under Certain } \\
\text { Conditions." }\end{array}$} \\
\hline 2c. & \multicolumn{5}{|c|}{ 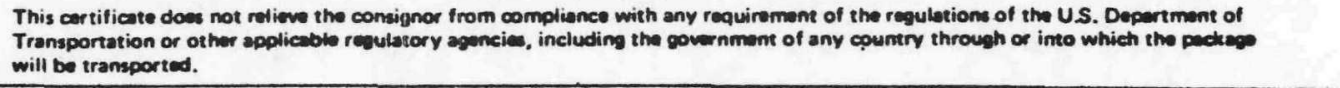 } \\
\hline
\end{tabular}

3. This certificate is iseued on the besis of a safety and ysis report of the peckaen deaign or application-

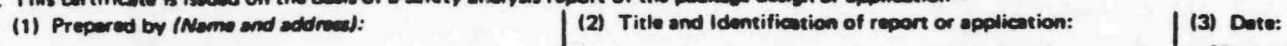

Oak Ridge National Laboratory

Post Office Box X

Oak Ridge, Tennessee 37830

Safety Analysis Report for Rackaging

November 1977 for the ORNL Urantum-Shlelded ShIpping Casks Report No. ORNL/ENG/TM-4

4. CONDITIONS

This certificate is conditionel upon the fulfilling of the requirements of Subpert D of 10 CFR 71, as applicable, and the conditions specified in item 5 below.

5. Description of Packaging and Authorized Contents, Model Number, Fissile Class, Other Conditions, and Aeforences:

(a) Packaging:

(1) Model(s): L and $M$

(2) Description:

Type B Packaging for large quantities of nonfissile radioactive material. The inner containment vessel which consists of a vessel meeting either special form or DOT Specification $2 R$, is determined by heat load as follows:

Heat Load (Watts)

$\leq 3000$

$>3000$

*Metallic gasket required.

The Inner containment vessels are positioned within right circular cylinders of $1 / 4$ inch thick stainless steel-clad depleted uranium having a plug-type, bolted and gasketed top 11d closure.

\begin{tabular}{|c|c|}
\hline 6a. Date of Issuance: August 30,1977 & 6b. Expiration Date: \\
\hline \multicolumn{2}{|c|}{ FOR THE U.S. ATOMIC ENERGY COMMISSION } \\
\hline $\begin{array}{l}\text { 7a. Address of Issuing Office: } \\
\text { U. S. Energy Research \& Development Adm. } \\
\text { Post Office Box E } \\
\text { Oale Ridge, Tennessee } 37830\end{array}$ & $\begin{array}{l}\text { 7b. Signature, Name, and Title of Approving Official: } \\
\text { Weenmen H Treovere } \\
\text { William H. Travis, Director } \\
\text { Safety \& Environmental Control Division }\end{array}$ \\
\hline
\end{tabular}


Page 2 - Certificate of Compliance, No. USA/5595/BL (ERDA-OR), Rev. 1

(a) (2) - Description (continued):

Details of the two Models are as follows:

Model L Model M

Cavity

I.D. (In.)

11

11

Height (in.)

$171 / 2$

$171 / 2$

Outside Dimensions

O.D. (in.)*

25

Height (in.)

$393 / 4$

38

Bottom Lug Plate

O.D. (In.)

$355 / 8$

$351 / 8$

*Excluding 3 in. deep fins

Minimum U Shield Thickness (in.)

$63 / 4$

6

Gross Weight** (1bs.)

13,200

11,600

* Inoluding skid

Each cask is mounted on a skid and covered with a personnel heat shield.

(3) Drawings

The packagings are as described and fabricated in accordance with the following Union Carbide Corporation, Nuclear Division, Paducah Plant Drawings:

Model L - M-11572-EM-001-E through -003-E

Model M - M-11572-EM-010-E through -014-E

(b) Contents

(1) Type and Form of Material Nonfissile radioactive materials in solid form.

(2) Maximum quantity of radioactive Material limited by the volume and shape of the internal cavity of each cask, internal heat 1oad, and external radiation levels prescribed in DOT Regulations, Title 49 CFR.

(3) Maximum decay heat load not to exceed 4000 watts; however, when the heat load exceed 1250 watts transport will be made by exclusive-use vehicle. 
-

-

- 
II.B. 101

B. RADIOACTIVE SOLIDS

ORNL FOAMGLASS SHIPPING CONTAINER 
ORNL Photo 0501-74

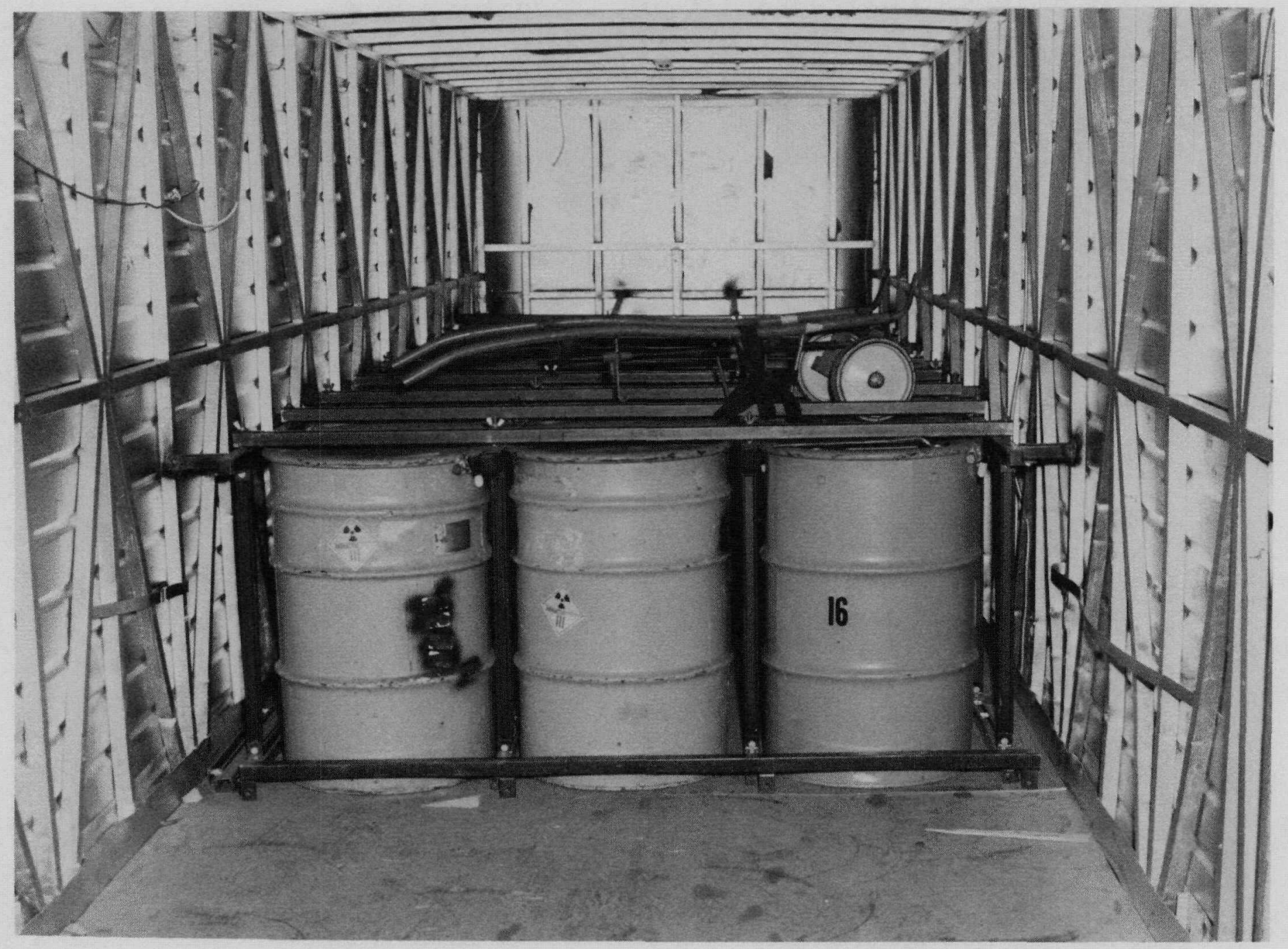

$ت$
$\stackrel{H}{+}$
$\stackrel{\circ}{\circ}$

ORNL Foamglass Shipping Container - Type B 
II.B.103

ORNL DWG 68-14352 R5

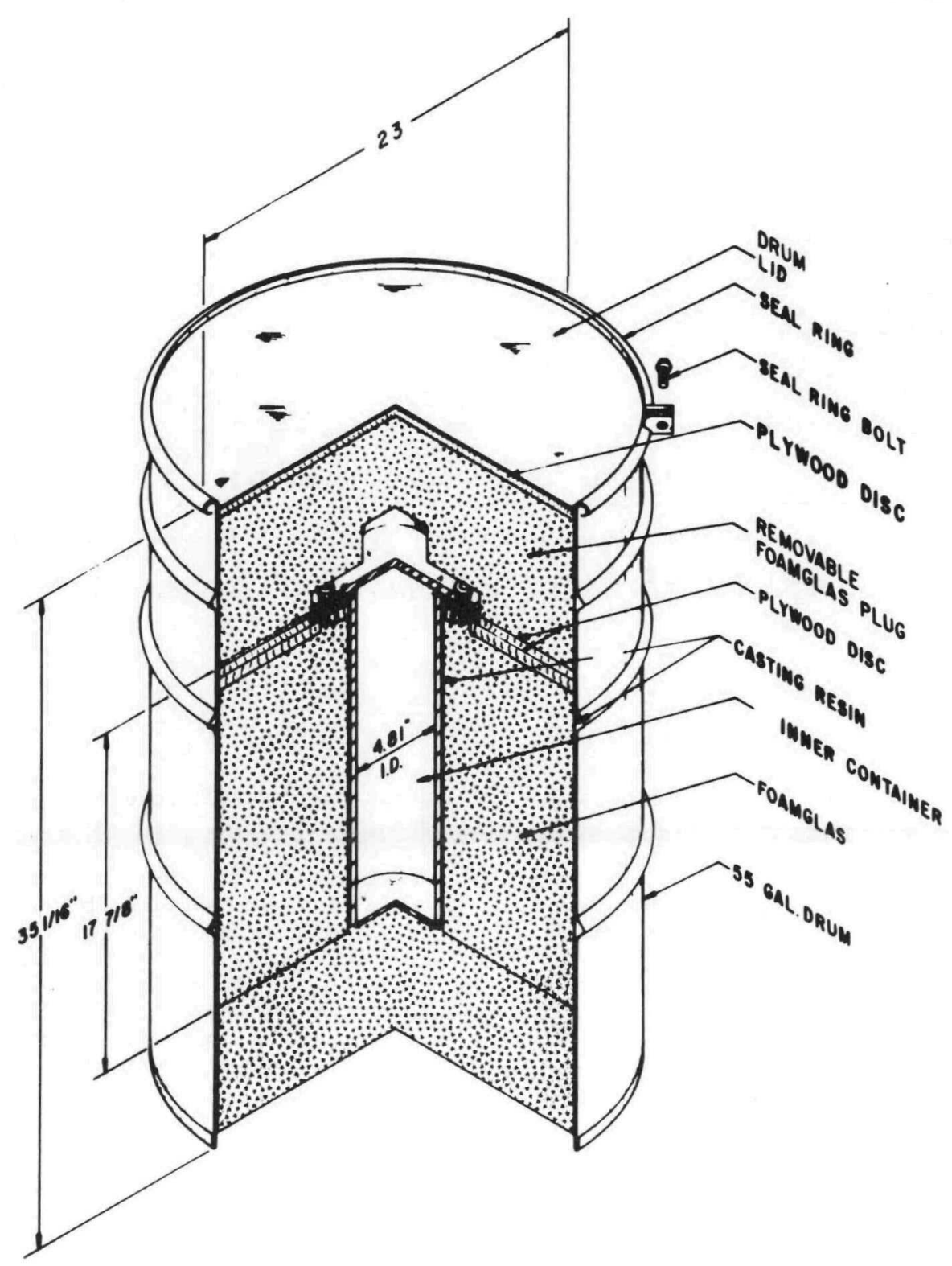

FOAMGLAS SHIPPING CONTAINER 
GOE Form EV\&10 10 CFR 111
U.S. DEPARTMENT OF ENERGY CERTIFICATE OF COMPLIANCE

For Radionctivo Materials Packapos

\begin{tabular}{l|l|l|l|l}
\hline $\begin{array}{l}\text { 10. Cortificate Number } \\
5795\end{array}$ & $\begin{array}{l}\text { 1b. Revision No. } \\
1\end{array}$ & $\begin{array}{l}\text { 1c. Package Identification No. } \\
\text { USA } / 5795 / \text { BLF (DOE-OR) }\end{array}$ & $\begin{array}{c}\text { 1d. Pago No. } \\
1\end{array}$ & $\begin{array}{c}\text { 10. Total No. Papes. } \\
3\end{array}$ \\
\hline
\end{tabular}

2. Paeamble

2a. This certificate is issued to satisfy Sections 173.393a, 173.394, 173.395, and 173.396 of the Depertment of Transportation Hazardous Materials Regulations (49 CFR 170-189).

2b. The packaging and contents described in item 5 below, meets the safety standards sat forth in Subpart $C$ of Title 10, Code of Federal Regulations, Part 71, "Packaging of Radioactive Material for Transport and Transportation of Radioactive Material Undee Certain Conditions."

2c. This certificate does not relieve the consignor from compliance with any requirement of the regulations of the U.S. Depertment of Transportation or other applicable regulatory agencies, including the government of any country through or into which the package will be transported.

3. This certificate is issued on the basis of a safety analysis report of the package design or application-

(1) Prepared by (Name and address):

Oak Ridge National Laboratory

Post office Box E

Oak Ridge, TN 37830

(2) Title and Identification of report or application:

Safety Analysis Report for Pack- January 1979 aging (SARP) of the Oak Ridge National Laboratory Foamglas Shipping Container

Report No.: ORNL-5407/RI

4. CONDITIONS

This certificate is conditional upon the fulfilling of the requirements of Subpart D of 10 CFR 71, as applicable, and the conditions specified in item 5 below.

5. Description of Packaging and Authorized Contents, Model Number, Fissile Class, Other Conditions, and References:

(a) Packaging

(1) Model: ORNL Foamglas

(2) Description:

Packaging for fissile material. The containment vessel is a flanged DOTSpecification 2R inside container consisting of a 4.81" I.D. $x 18^{\prime \prime}$ long Schedule 80 stainless steel pipe (0.375" wall thickness) with a $1 / 4$ " thick welded bottom plate. The flange is sealed with a $1 / 8$ " thick $x$ " I.D. $x$ 10" 0.D. silicone gasket. Fissile material is contained inside sealed metal cans within the containment vessel. Void space inside the containment vessel may be filled with crumpled aluminum foil. The containment vessel is supported inside a DOT Specification $17 \mathrm{H} 55$-gallon drum by solid foamed boron silicate glass (foamglas). The outer steel drum is 23" $0 . \mathrm{D}$. $x$ $351 / 16^{\prime \prime}$ long. It has a 12-gage bolted closure ring with drop forged lugs, one of which is threaded, and has a 5/8" steel bolt and lock nut. The package gross weight is $2151 \mathrm{~b}$.

(3) Drawing:

The packaging is as described and is fabricated in accordance with ORNL Drawing 68-14352R6

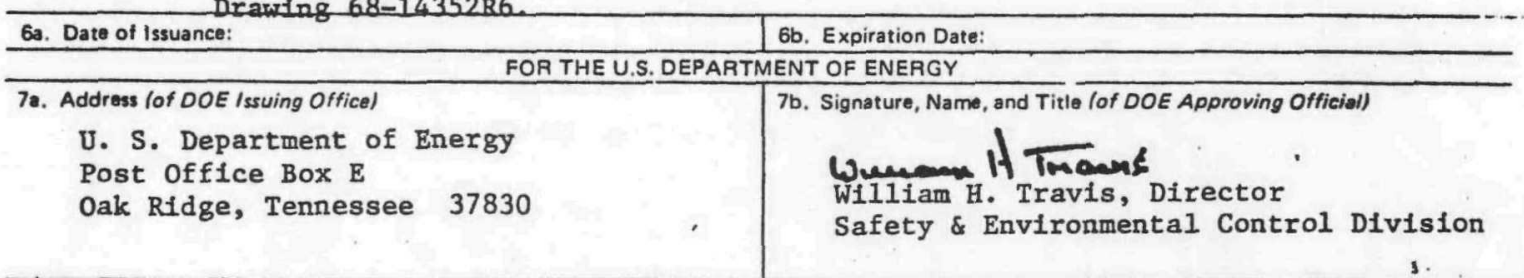


Page 2 - Certificate of Compliance, No.: 5795, Revision 1

(b) Contents

(1) Type and form of material:

Uranium and plutonium isotopes either singly or in mixture,

as metal oxide. Uranium may contain up to $100 \% 23{ }^{23} \mathrm{U},{ }^{235} \mathrm{U}$, or ${ }^{238} \mathrm{U}$.

Plutonium in quantities greater than $50 \mathrm{~g}$ will contain at

least $60 \mathrm{wt} \%{ }^{239} \mathrm{Pu}$, more ${ }^{240} \mathrm{Pu}$ than $241 \mathrm{Pu}$, and $238 \mathrm{Pu}$ will

be considered as ${ }^{239} \mathrm{Pu}$.

(2) Maximum quantity of material per package:

Not to exceed 10 watts thermal decay and for the fissile contents decribed in $5(\mathrm{~b})(1)$, the assignment of the transport Index for Fissile Class II is consistent with the following 1 imitations of form, mass, $H: X$ ratio, and density:

Mass (kg of $\mathrm{X}$ )

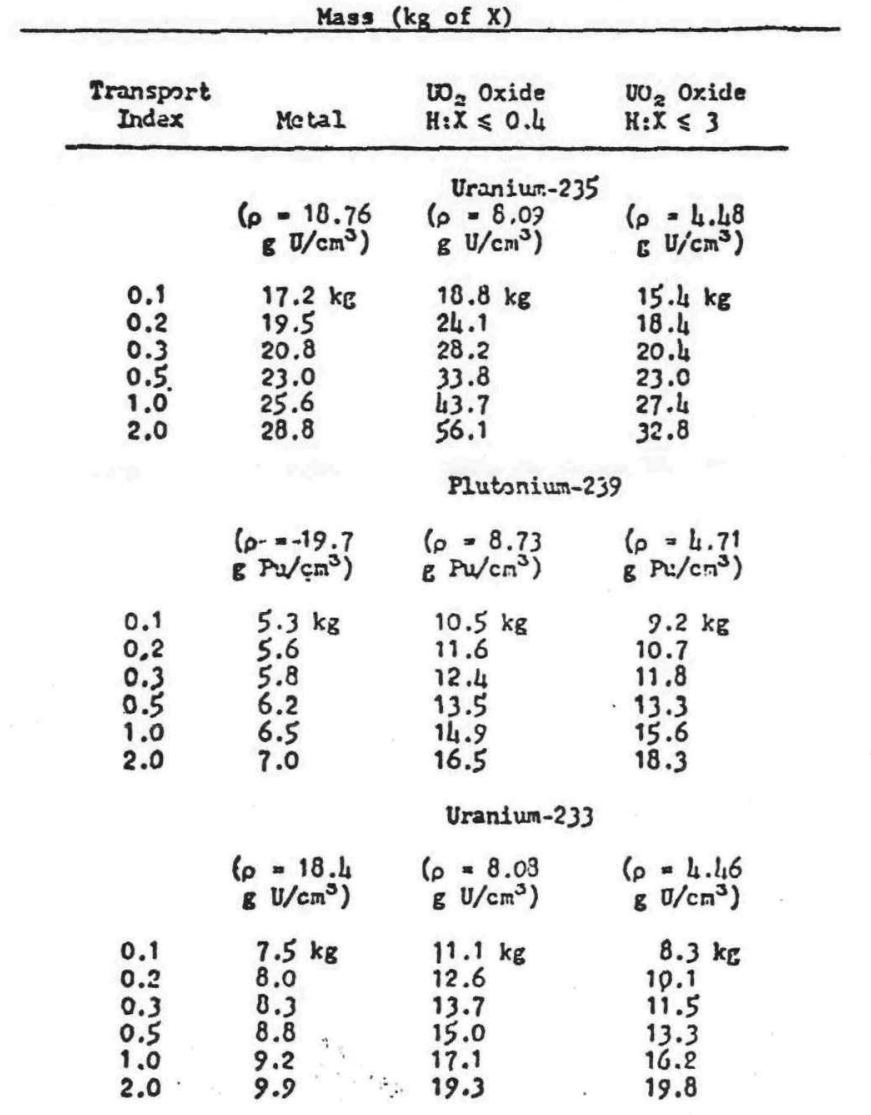




\section{II.B.106}

Page 3 - Certificate of Compliance, No.: 5795, Revision 1

(c) Fissile Class

II and III

(1) Minimum transport index to be be shown on label for Class II

0.1

(2) Maximum Transport Indexes per shipment for Class III

(d) External radiation levels will conform to US DOT Regulations, 49 CFR 173.393.

(e) ORNL foamglas containers loaded with $\mathrm{Pu}$ in excess of $20 \mathrm{Ci}$ will be transported in SST's (Safe Secure Trailers) operated by USDOE-ALO in order to conform to $10 \mathrm{CFR} 71.42(\mathrm{~b})$. 
II.B. 107

\section{B. RADIOACTIVE SOLIDS}

Y-12 DT-14 PACKAGING FOR ENRICHED URANIUM 
II.B. 108

ORNL Photo 2865-78

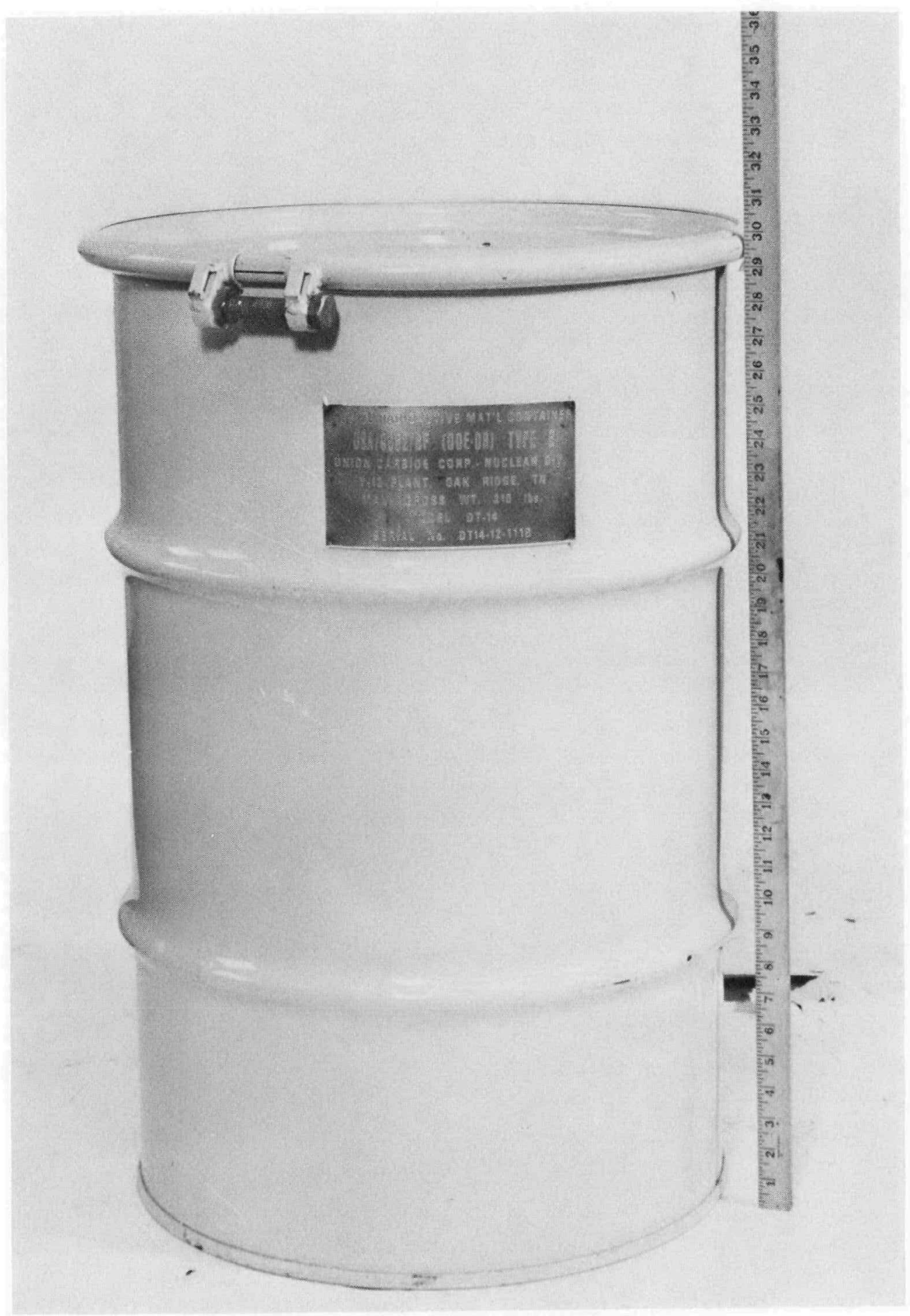

Y-12 DT-14 Package for Enriched Uranium Type B 


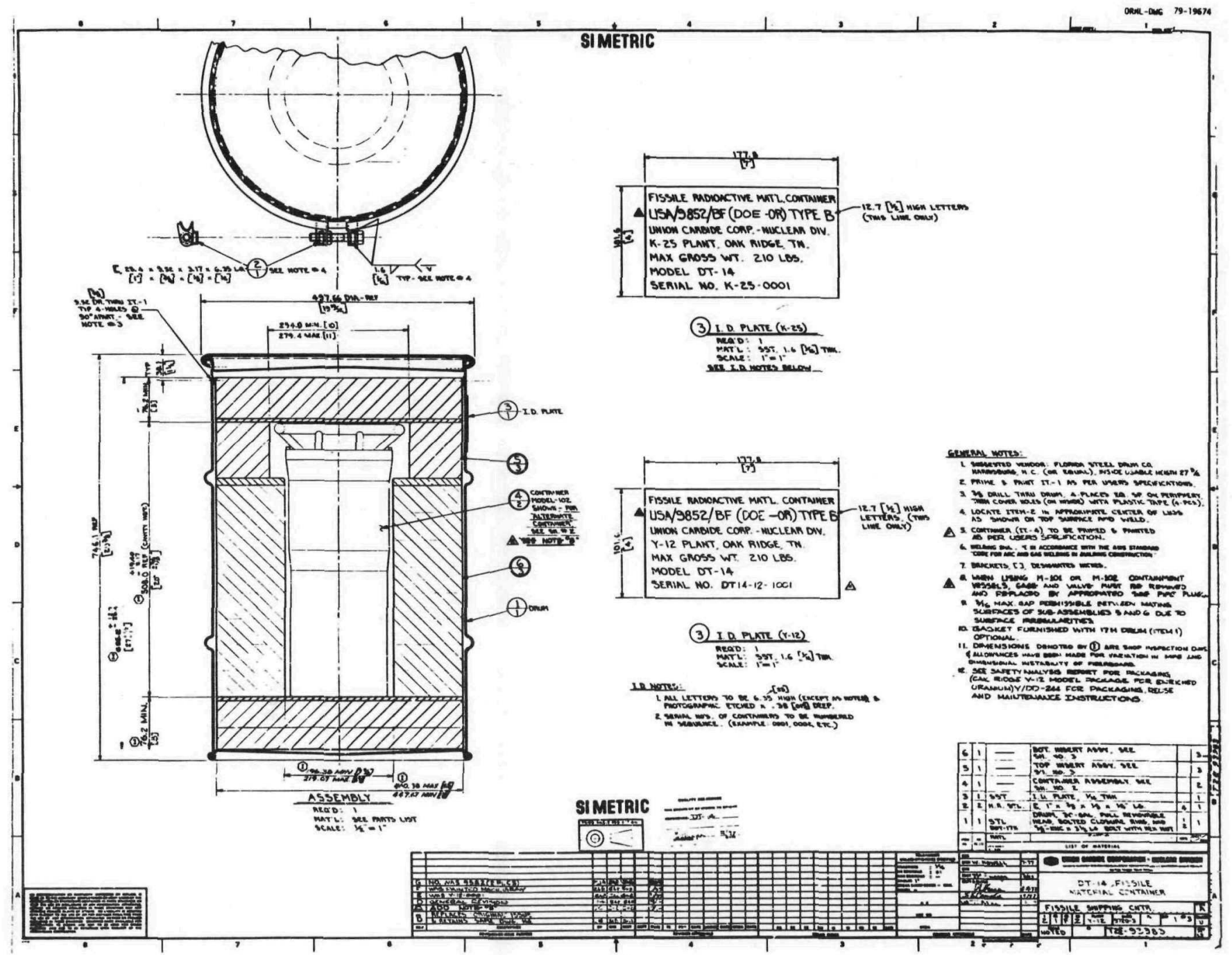




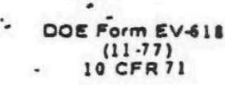

U.S. DEPARTMENT OF ENEAGY

CERTIFICATE OF COMPLIANCE

For Radioactive Materials Packages

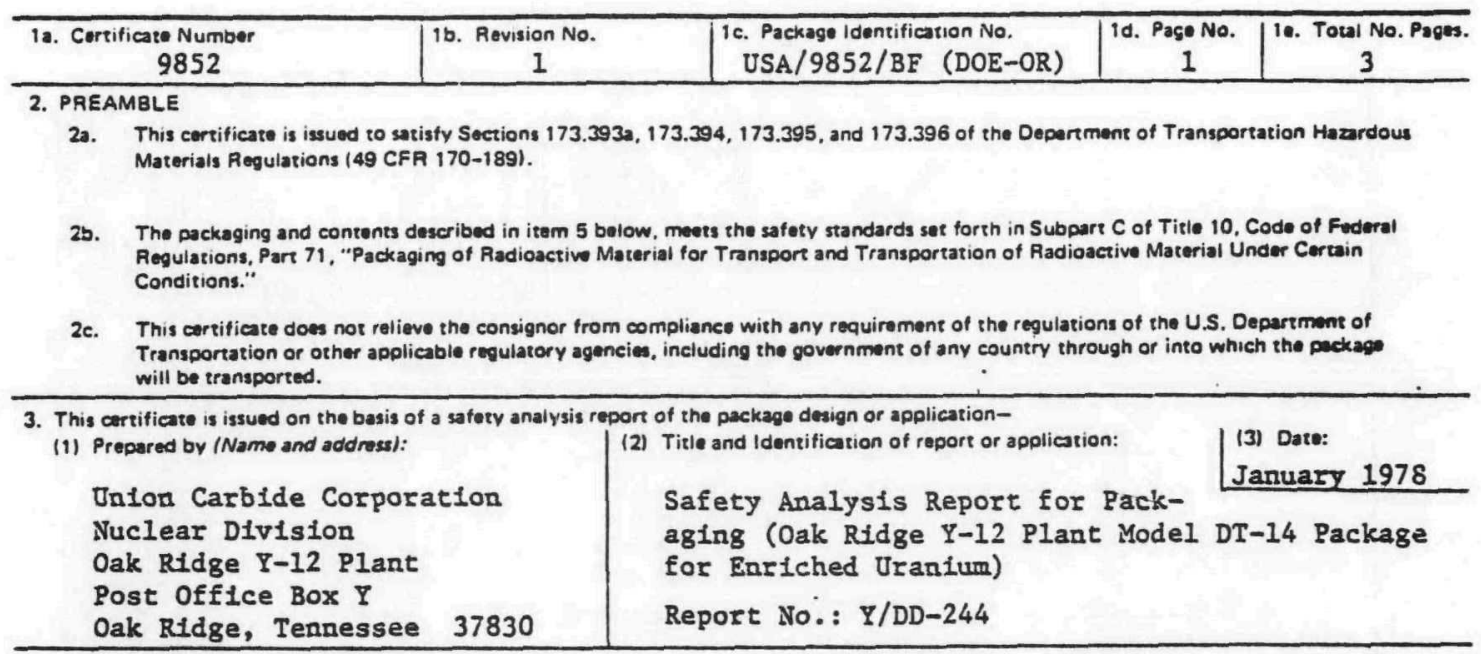

4. CONDITIONS

This certificate is conditional upon the fulfilling of the requirements of Subpart D of 10 CFR 71, as applicable, and the conditions specified in item 5 below.

5. Description of Packaging and Authorized Contents, Model Number, Fissile Class, Other Conditions, and References:

\section{(a) Packaging:}

(1) Model: DT-14

(2) Description:

Packaging for uranium enriched in the U-235 1sotope. The primary Containment Vessel consists of either a polyethylene bottle with a normal wall thickness of $1.0 \mathrm{~mm}$ ( $40 \mathrm{mils}$ ) or greater or a metal can with a nominal wall thickness of $0.254 \mathrm{~mm}$ ( $10 \mathrm{mils}$ ) such as DOT Specification $2 \mathrm{~A}$ or $2 \mathrm{~N}$. The Containment Vessel consists of (i) Inner Containment Vessel from Los Alamos M-101 with breech lock. closure held in place by at least three set screws, (i1) inner Containment Vessel from Rocky Flats M-102 with breech lock closure held in place by at least three set screws, or (iii) alternate vessel of steel pipe tubing 6.5" I.D. x $0.25^{\prime \prime}$ wall thickness $\times 15.5$ " long with

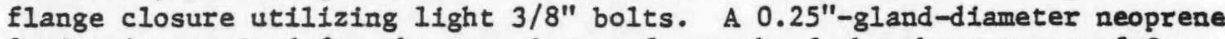
$0-r i n g$ is required for the top closure for each of the three types of Containment Vessels. Flange bolts are torqued to at least 1 foot-pound. The Containment Vessel is centered and supported within an 18 gauge DOT Spec. 17H - 30 gallon size drum by cane fiberboard insulation with a minimm density of $14 \mathrm{Ib} / \mathrm{ft}^{3}$. One-quarter inch plywood discs will be provided as load bearing surface both above and below the inner Containment Vessel. The

\begin{tabular}{l|l|l}
\hline 6a. Date of Issuance: May 22, 1978 & 6b. Expiration Date: \\
\hline
\end{tabular}

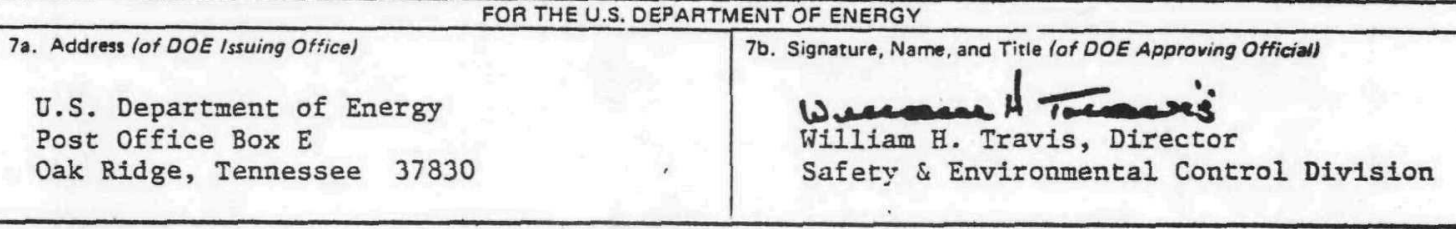


Certificate of Compliance, USA/9852/BE, - 2 Revision 1

outer steel drum closure must be at least a 12-gauge bolted ring with drop forged lugs, one of which is threaded, and having a 5/8" steel bolt and lockaut. The package gross weight is $210 \mathrm{lb}$.

(3) Drawings:

(a) The packaging is as described and fabricated in accordance with the Un10n Carbide Corporation, Nuclear D1vision, Oak R1dge Y-12 Plant Drawlags (Figures $1,2,3$ and 4 , and Pages $6,7,9$, and 10 respectIvely of Report Y/DD-244).

(b) Conkents:

(1) Type and forn of materfal.

Enriched uranium at any U-235 enrlchment as metal, compounds or solutions.

(2) Maximum quant1ty of material per package not to exceed Type $B$ quantities of radloactive material and not more than $21 \mathrm{~kg}$ of $\mathrm{D}-235$.

(3) Maximum interal heat load not to exceed 10 watts.

(c) Fissile Class:

II and III

(1) Transport Index to be shown on label for Class II based on loading and conditions as follows:

\begin{tabular}{|c|c|c|c|c|c|c|c|}
\hline \multirow[b]{2}{*}{$\begin{array}{l}235 \text { U Dentiry (g/em }{ }^{3} \text { ) - } \\
\text { H/235 U Atom Patio - }\end{array}$} & \multirow{2}{*}{$\begin{array}{l}\text { Metwil or } \\
\text { Alloys (1) } \\
<18.78 \\
0.00\end{array}$} & \multicolumn{5}{|c|}{ Mixatren, Comoounds, and Solutions (2) } & \multirow{2}{*}{$\begin{array}{l}\text { Assigned } \\
\text { Transport } \\
\text { Indexe }\end{array}$} \\
\hline & & $\begin{array}{l}<8.33 \\
<0.43\end{array}$ & $\begin{array}{l}<.55 \\
<3.22\end{array}$ & $\begin{array}{l}<2.05 \\
<10.7\end{array}$ & $\begin{array}{l}<1.15 \\
<21.4\end{array}$ & $\begin{array}{l}<18.78 \\
\text { Unlimized }\end{array}$ & \\
\hline \multirow{7}{*}{$\mathrm{KG} \cdot \longrightarrow$} & 10.0 & 9.5 & 7.0 & 4.7 & 3.3 & 0.30 & 0.1 \\
\hline & 14.5 & 13.3 & 93 & 5.8 & 39 & 0.45 & 0.3 \\
\hline & 120 & 16.5 & 11.2 & 6.6 & 4.4 & 0.58 & 28 \\
\hline & • & 19.3 & 128 & 7.2 & 4.8 & 0.70 & 1.0 \\
\hline & - & 21.0 & 14.0 & 7.7 & 5.0 & 0.75 & 1.4 \\
\hline & - & • & 16.0 & 8.5 & 5.5 & 0.85 & 2.3 \\
\hline & $\bullet$ & - & $\cdot$ & - & $\cdot$ & $1 . \infty$ & 5.0 \\
\hline
\end{tabular}


Certificate of Compllance, USA/9852/BF, - 3 Reviston 1 -

Note: Total matarial contents within inner Containment Vessel must not exceed $30 \mathrm{~kg}$. Bergllium and deuterfum not permitced. Low-density ( $51.0 \mathrm{~g} / \mathrm{cm}^{3}$ ) packaging material, with oo incermingling with fissile materfal may cushion material within fnner Containment Vessel.

(a) Multiple metal pieces for which any piece has a volume-to-suriace ratio less than a one-inch cube ( $V / S \leq 0.17$ 1n) shall be securely grouped together in elther polyethylene bottle or metal can. Examples of such items are one-half-inch cubes, thin plates measuring $2^{\prime \prime} \times 8^{\prime \prime} \times 0.42 "$, or pieces of undeterminable surface area with a minimum dimension < 1 inch.

$\leq 120$ grams of packaging material may be interstitially used for metal pieces. Greater packag1ng-material masses require that the reserfetions on mixtures, compounds, and solutions be observed.

Alloying materlal masses shall be assumed to be ${ }^{235} \mathrm{U}$, except where alloying reduces the actual $235 \mathrm{U}$ density below $8.33 \mathrm{~g} / \mathrm{cm}^{3}$. Alloys with $23 \mathrm{~J}_{0}$ densities $\leq 8.33 \mathrm{~g} / \mathrm{cm}^{3}$ may be packaged as mixtures, compounds, and solutions.

(b) Uranium hydrides with densitles $>4.55 \mathrm{~g} / \mathrm{cm}^{3}$ not permited. A water-t1ght polyethylene bottle with a 1-um minimum wall thickness shall be used to contain solutions or dry compounds. Dry compounds may be placed IIr water-tight metal cans.

(2) Maximum transport 1ndex per shipment for Class III 
II.B. 113

B. RADIOACTIVE SOLIDS

ORNL UNIRRADIATED FUEL SHIPPING CONTAINER 


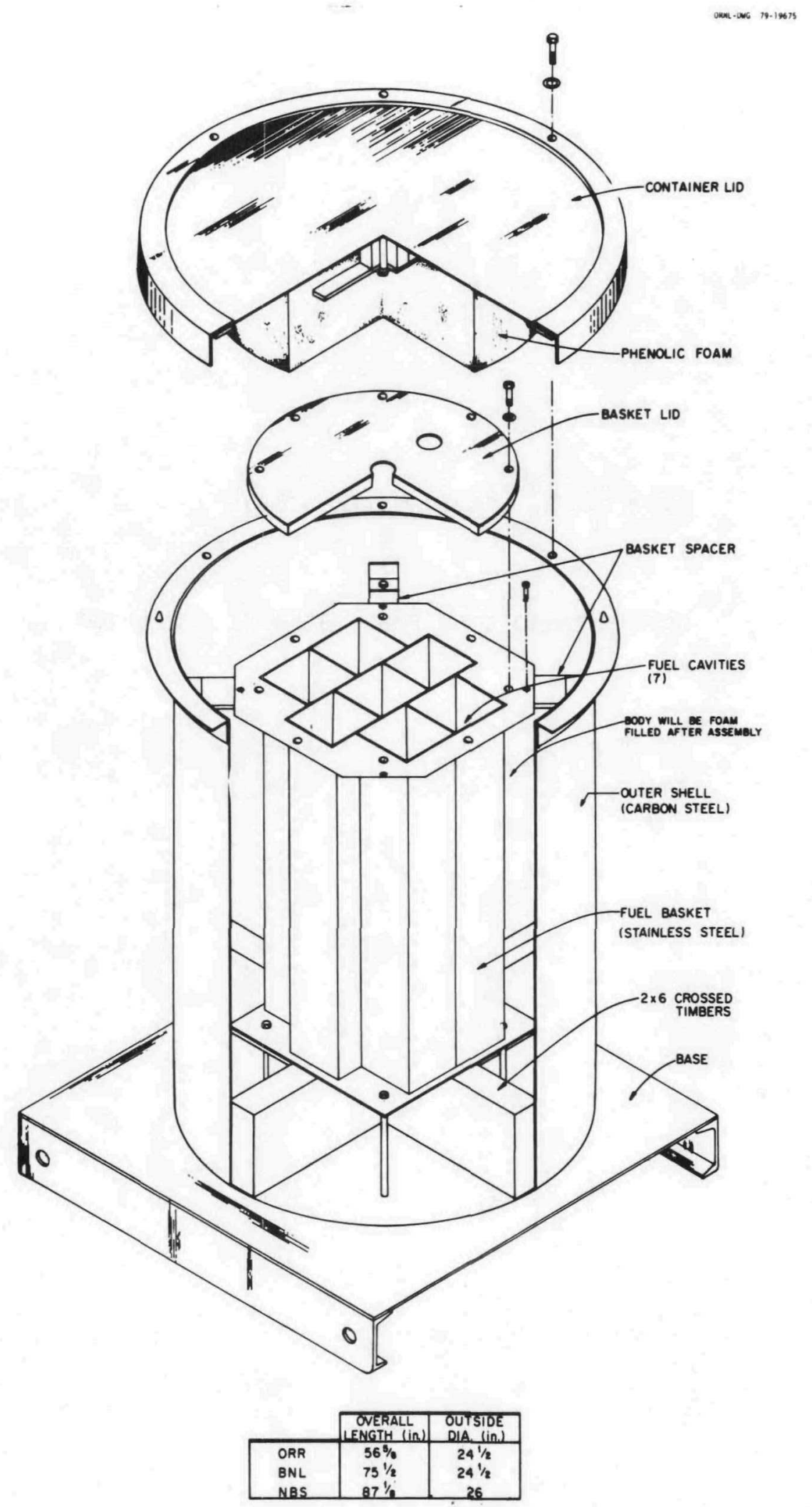

ORNL Unirradiated Fuel Shipping Container - Type B 
DOE Form EV-618

10 (1) CFR')
U.S. DEPARTMENT OF ENERGY

CERTIFICATE OF COMPLIANCE

For Radioactive Materials Packages

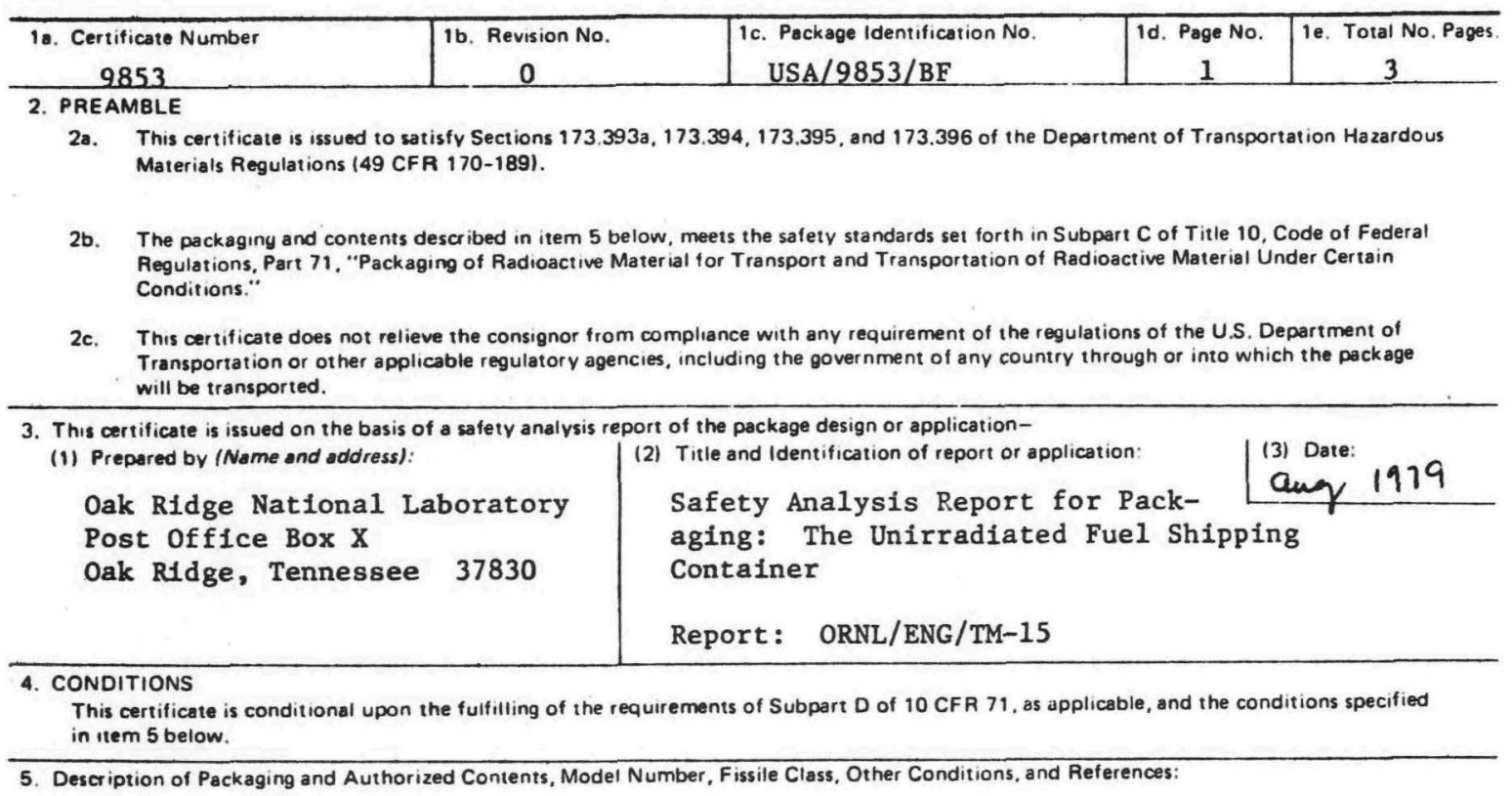

a. Packaging:

(1) Model: ORNL Unirradiated Fuel Shipping Container

(2) Description:

Packaging for unirradiated fissile material as fuel elements. The fuel elements are positioned in a basket consisting of seven square cavities fabricated from 16 gauge plate and a base fabricated from eleven gauge plate. The plate is Type 300 stainless steel. Eight $3 / 8^{\prime \prime}$ nuts and bolts retain the basket lid, which is made from $0.125^{\prime \prime}$ thick aluminum, in place. The basket is positioned inside a cylindrical outer shell. The outer shell and lid are fabricated from eleven gauge plate and the base is $1 / 4$ " thick plate. The plate for the shell is Type 300 stainless steel. The outer lid is held in place by six 5/8" nuts and bolts. The basket is supported on 2 " $x$ 6" timbers inside the outer shell. The remaining space around the basket is filled with phenolic foam insulation.

There are different types of packages. Table I describes the details of each design.

b. Contents:

(1). Type and form of material

The wranium is enriched to $293 \% 235 \mathrm{U}$ and is in the oxide form. It is

\begin{tabular}{|c|c|}
\hline 6a. Date of Issuance JUN 41979 & 6b. Expiration Date: \\
\hline \multicolumn{2}{|c|}{ FOR THE U.S. DEPARTMENT OF ENERGY } \\
\hline $\begin{array}{l}\text { 7a. Address (of DOE Issuing O'fice) } \\
\text { U. S. Department of Energy } \\
\text { Post Office Box E } \\
\text { Oak Ridge, Tennessee } 37830\end{array}$ & $\begin{array}{l}\text { 7b. Signature, Name, and Title fof DOE Approving Officiall } \\
\text { '//,iten. It Thanas' } \\
\text { Wiliam H. Travis, Director } \\
\text { Safety and Environmental Control } \\
\text { Division }\end{array}$ \\
\hline
\end{tabular}


III. 1

III. COMMERCIAL PACKAGES SHIPPED FROM ORNL

(NRC or DOT Approved)

TECHNICAL OPERATIONS 
III. 2

ORNL Photo 2417-78

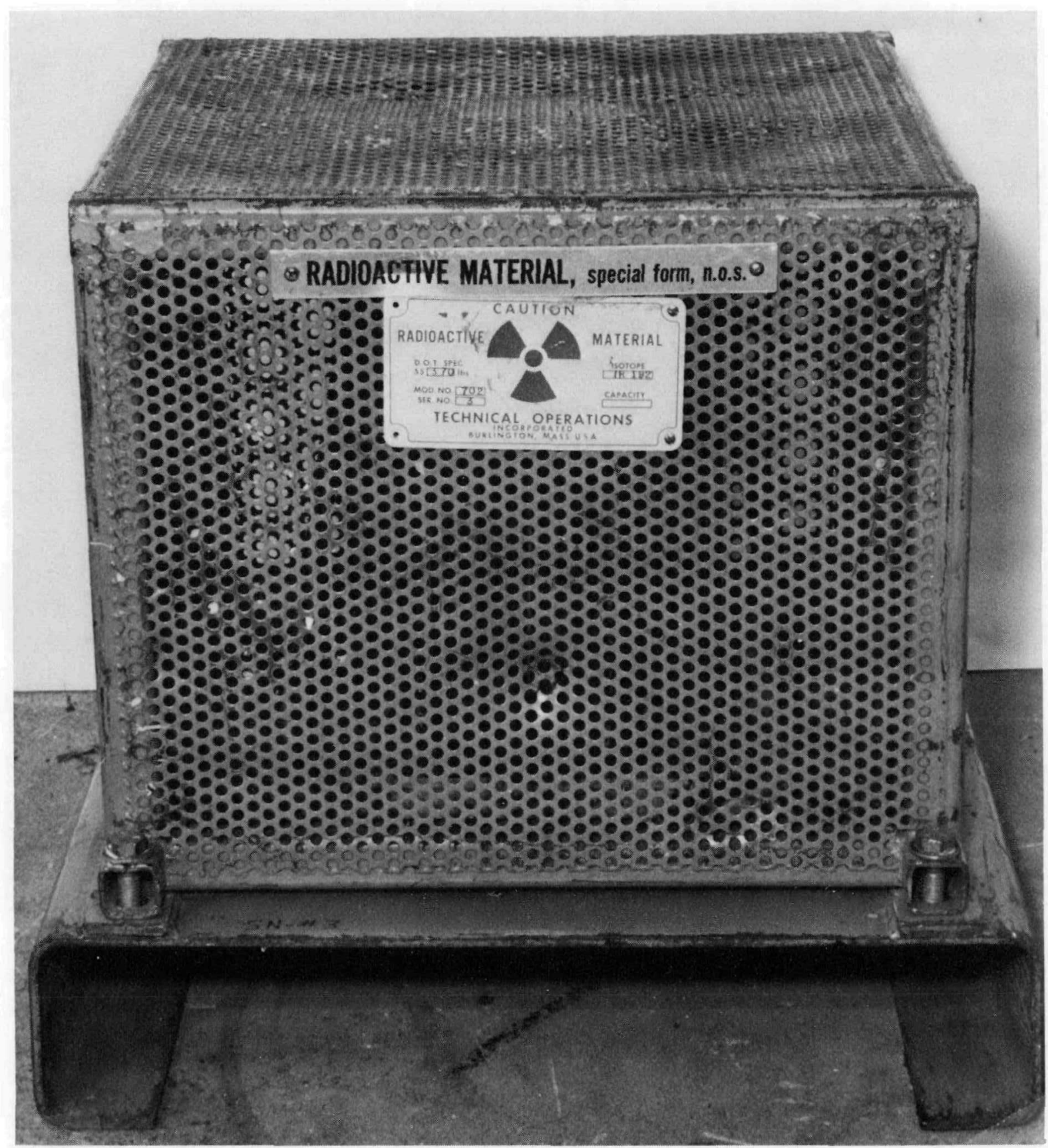

Technical Operations Iridium-192 Cask Type B 
III. 3

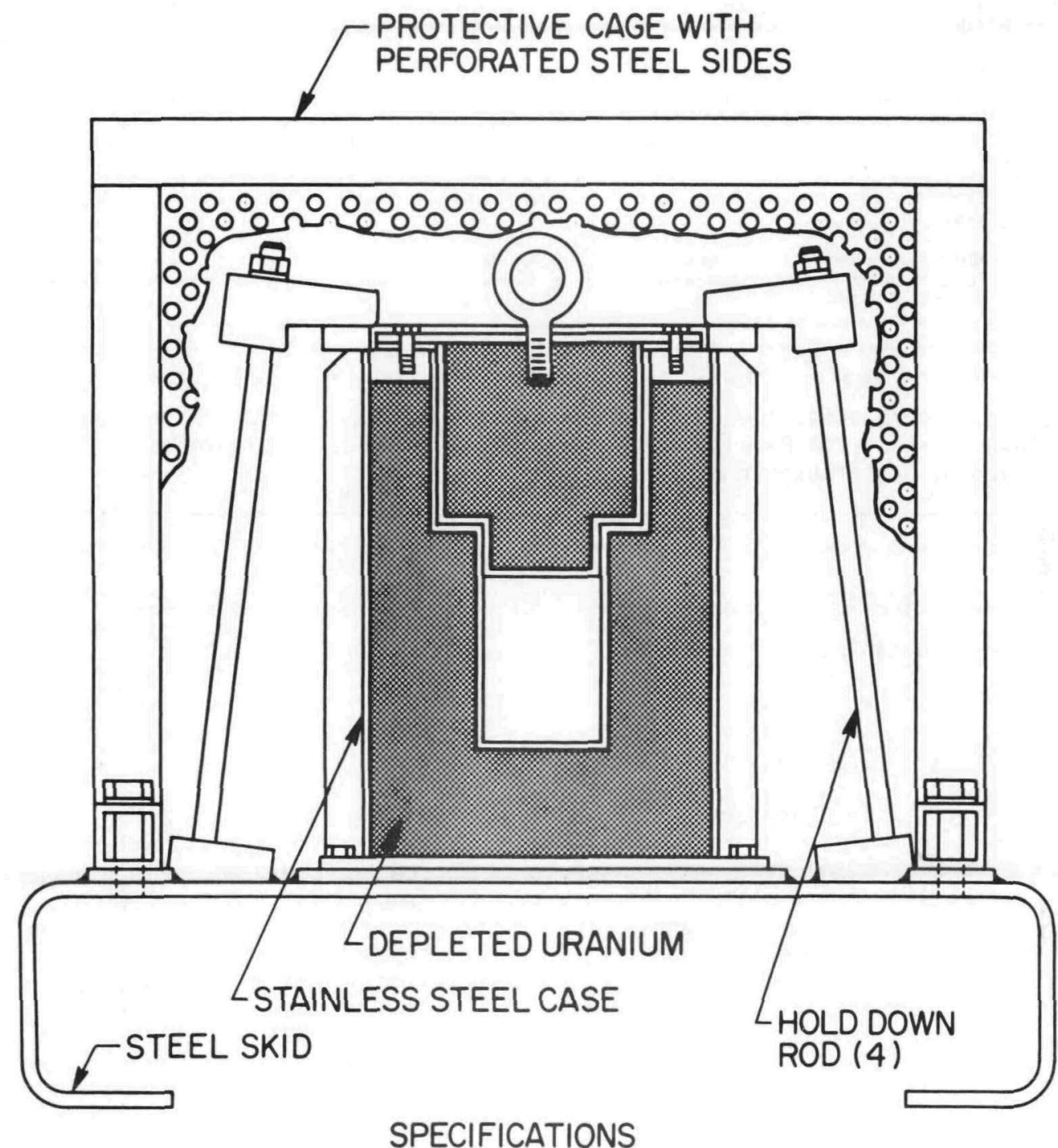

SIZE -21 in. $W \times 21$ in. $L \times 20$ in. $H$

WT. OF DEPLETED URANIUM - 209 LBS.

TOTAL WEIGHT — 370 LBS.

TECHNICAL OPERATIONS INC.

MODEL 702

IRIDIUM-192 SHIPPING CONTAINER 


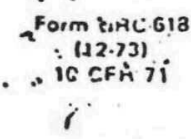

2.(a) This certificate is issued to satisly Sections 173.3933, 173.394, 173.395, and 173.396 of the Depurtment of Transportatian Haxardous P.Isterials Fmulations (49 CFR 170.189 and 14 CFR 103) and Sections 146-19-103 and 146-19-100 of the Department of Transportation Dangerous Cargoes Regulations (46 CFR 146-149), as amended.

2.(u) The pack.nging and contents described in item 5 below, meets the salety standards set forth in Subpart C of Title 10. Code of Federal Regulutions. Part 71. "Packaging of Rodiosctive Materials for Transport ond Transportstion of Radioactive Material Under Certsin Conditions."

- 2.(c) This certificste does not relieve the consignor Irom compliance with any requirement of the regulations of the U.S. Department of Trunsportation or other applicable regulatory agencies, including the government of any country through or into which the package will be transported.

3. This certilicate is issued on the basis of a salety analysis report of the package design or application-

3.(a) Prepored by (Name and address):

Technical Operations, Inc. Northwest Industrial Park Burlington, Massachusetts 01803 3.(b) Titie and identifiration of report or application:

Technical Operations, Inc. application dated October 14, 1971, as supplemented.

3.(c) Docket No. $71-6613$

4. CONDITIONS

This certificate is conditional upon the fulfilling of the requirements of Subpart D of 10 CFR 71, as applicable, and the conditions sdpen in item 5 below.

5. Description of Packaging and Authorized Contents, Model Number, Fissile Class, Other Conditions, and Relerences:

(a) Packaging

(1) Model No.: 702

(2) Description

The cask system overall dimensions are $21 " \times 21 " \times 20 "$. The shielding container is a stainless steel-depleted uranium-stainless. steel stepped annulus closed at one end and with a lid closure at the other. The base plate is square in shape and extends outside the annulus to provide a base for the twenty-four fins and space for placing four tie down bolts. The top cover is equipped with an eye bolt and two drain and vent plugs, is secured to the main body of the cask by four stainless steel $3 / 8$-inch bolts. The top cover is sealed with a 0.0625 inch. thick rubber gasket. The annulus formed by the stainless steel : shells is filled with depleted uranium. Copper sheets are placed ... between the uranium-stainless steel interfaces. Connecting the outer and inner shell assemblies at the top of the cask is a 5/8-inch thick stainless steel flange ring.

The flange ring has four holes to accommodate the cask cover bolts. The skid is made of $1 / 4$-inch thick hot rolled steel plate reinforced with 1/4-inch plates at points where the cask and the cage 
Page 2 - Certificate No. 6613 - Revision No. 0 - Docket No. 71-6613

will be bolted to it. The cask is mounted on the skid with four $1 / 2$-inch bolts and a tie down system consisting of four 1/2-inch diameter threaded rods, base supports and top brackets. The cage is constructed of $11 / 4$-inch square steel tubing and perforated 18 gauge steel sheets tack welded to. the tubular frame. Haximum gross weight of the packaging is 370 pounds.

(3) Drawings

The cask and other system components are constructed in accordance with the following Technical Operations, Inc. Drawings Nos. and Bill of Materials Nos.: D70202, Rev. D; B/M 70202, Sheets 1 and 2, Rev. none; B708, Rev. E; A70201-1, Rev. none; A70205-2, Rev. none; C70205-1, Rev. none; C70201, Rev. none; C70205, Rev. none; B70203, Rev. none; B/M 70203, Rev. none; A70202-1, Rev. A; D70206, Rev. none; and D70204, Rev. A.

(b) Contents

- (1) Type and form of material

Metallic iridium 192.

(2) Maximum quantity of material per package

10,000 curies.

(3) Maximum decay heat per package

100 watts.

6. The 10,000 curies of iridium 192, in metallic form, shall be enclosed in steel special form capsules shown in Drawing No. B708, Rev. E, which are assembled with a new copper gasket and closed with a minimum torque of $15 \mathrm{ft}-1 \mathrm{~b}$.

7. The package authorized by this certificate is hereby approved for use under $\cdots$. the general license provisions of Paragraph 71.12(b) of 10 CFR Part 71.

8. Expiration date: March 31, 1982. 
III. 6

Page 3 - Certificate No. 6613 - Revision No. O - Docket No. 7I-6613

\section{REFERENCES}

Technical Operations, Inc. applicated dated October 14, 1971.

Supplements dated: January 10 and February 11, 1972.

FOR THE U.S. NUCLEAR REGULATORY COMMISSION

$$
\begin{gathered}
\text { R\& Olegaorelen } \\
\text { for Charles E. MacDonald, chief } \\
\text { Transportation Branch } \\
\text { Division of Fuel Cycle and } \\
\text { Material Safety }
\end{gathered}
$$

Date: Jun 131977 
III. 7

III. COMMERCIAL PACKAGES SHIPPED FROM ORNL

(NRC or DOT Approved)

GENERAL ELECTRIC COMPANY 
ORNL Photo 2418-78

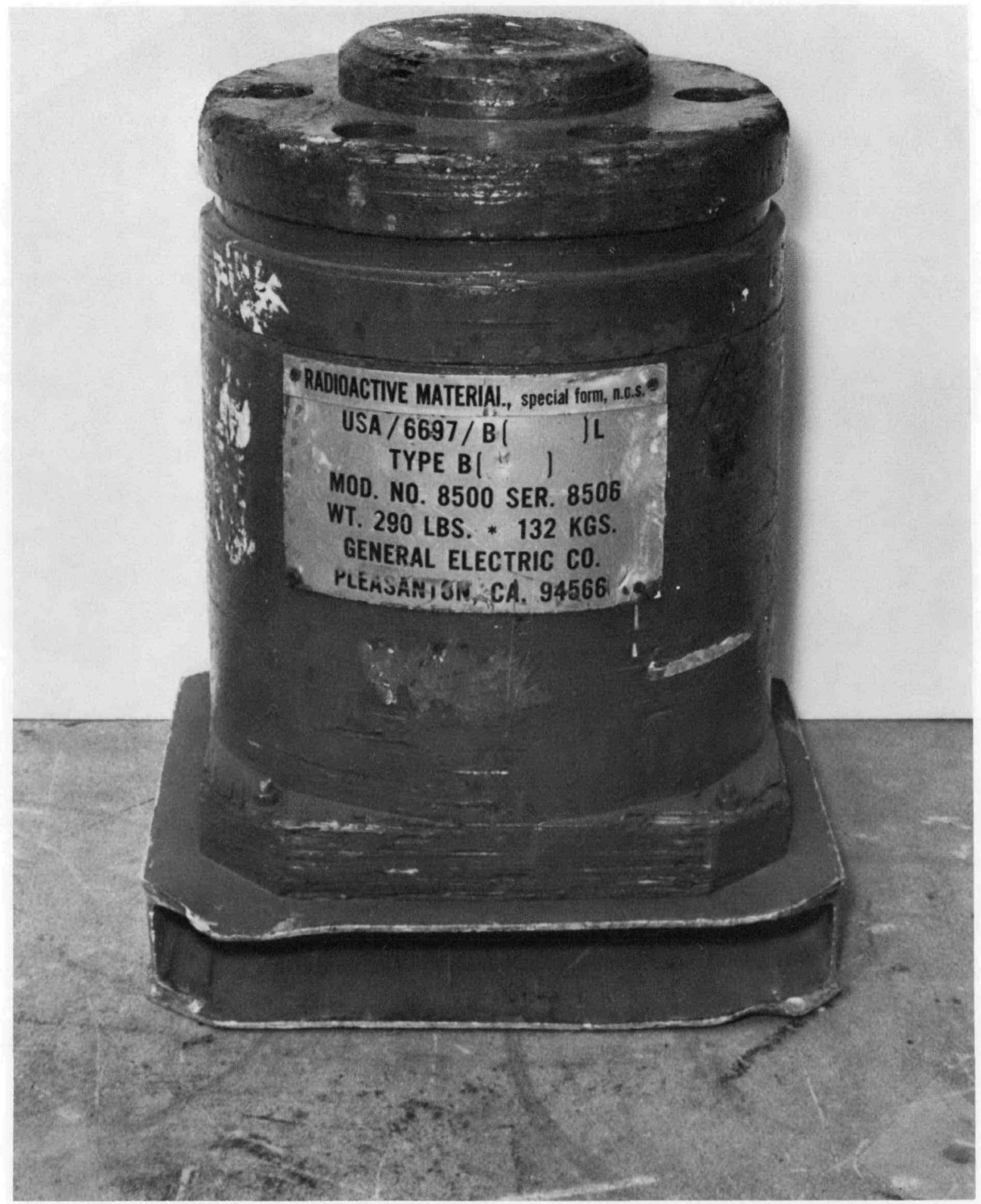

General Electric Shipping Container

Type B 
III.9

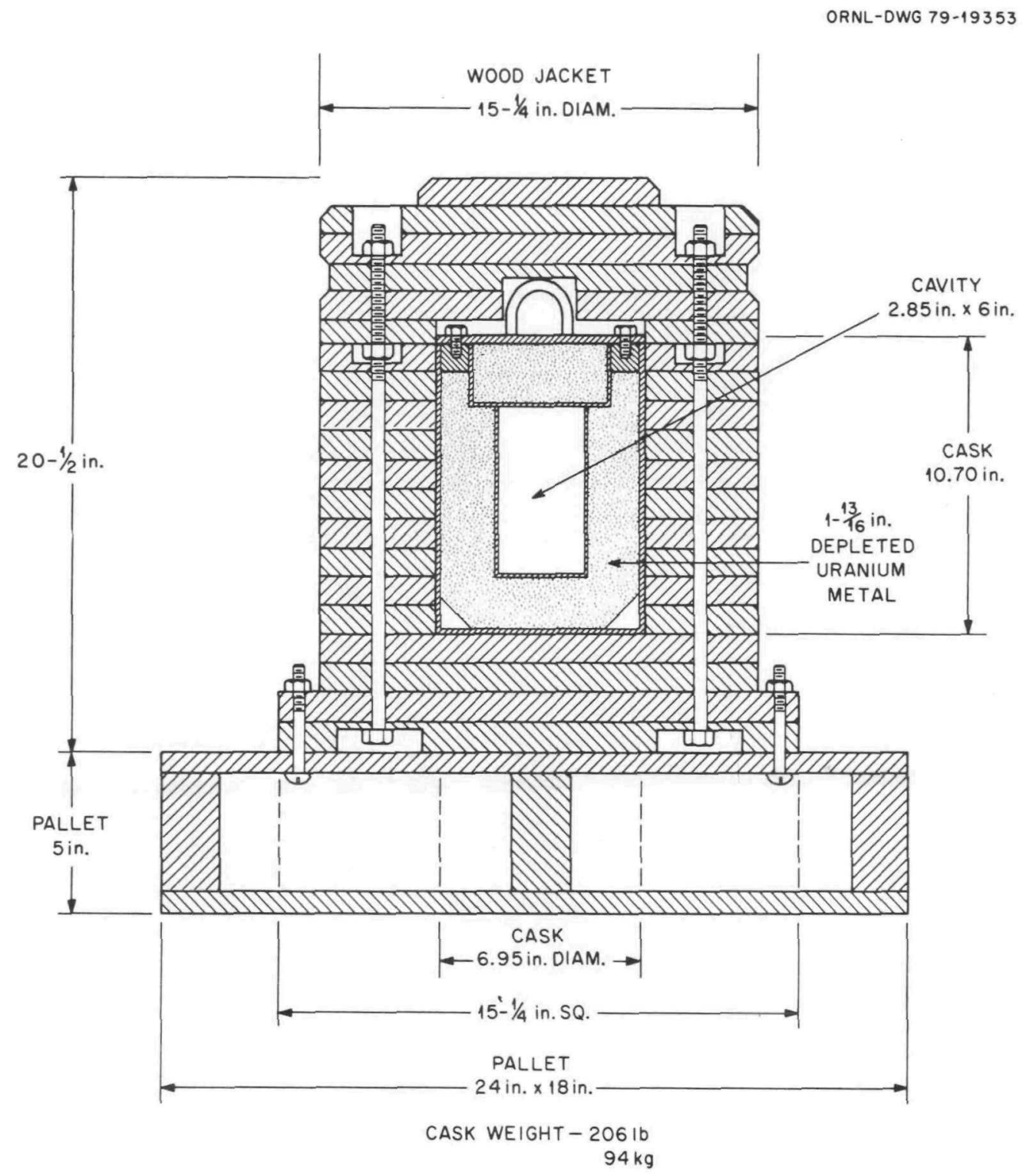

GENERAL ELECTRIC - MODEL 8500 SHIELDED CONTAINER 


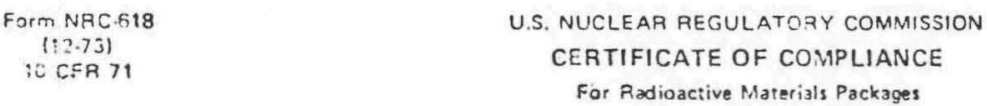

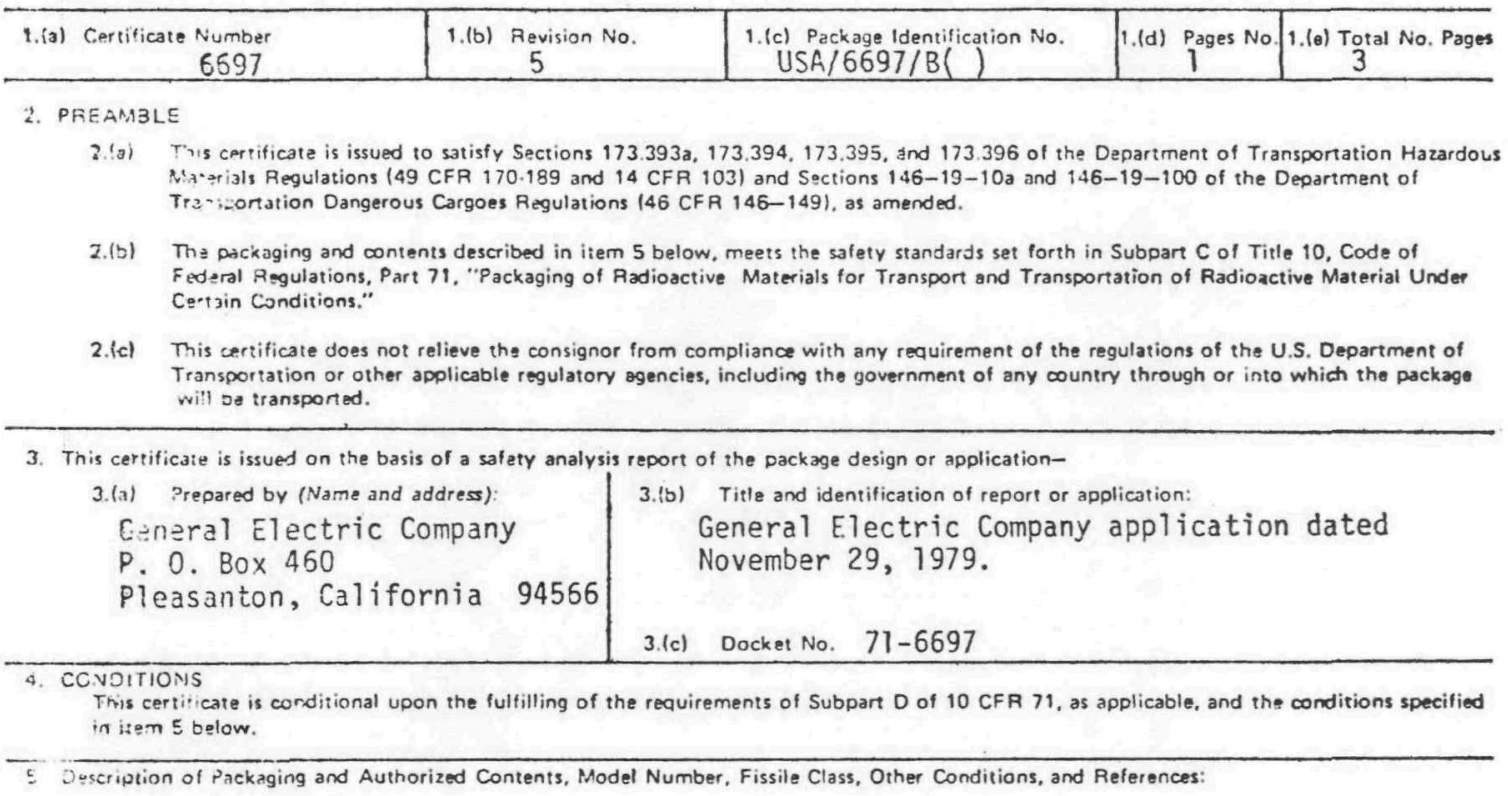

(a) Packaging

(1) Nodel No.: GE-8500

(2) Description

The packaging is a steel, uranium shielded shipping cask surrounded by a laminated plywood protective jacket.

The inner shielded cask is an upright circular cylinder, consisting of an inner she11, 2-7/8 inches ID $\times 6-1 / 8$ inches high, made of $1 / 8$-inch thick stainless steel which is surrounded by $1-13 / 16$ inches of depleted uranium and enclosed in a 7 -inch $00 \times 10-1 / 2$-inch high $x$ lid-inch thick stainless steel outer shell.

Closure is by means of six, 3/8-inch diameter bolts and a $1 / 8$-inch thick neoprene rubber gasket between body and lid. The shielded cask is positionad in a two-piece protective jacket of solid plywood laminations which is bolted to a rectangular pallet made of aluminum.

The protective jacket is $15-1 / 4$ inches $O D \times 20-1 / 2$ inches high and together with the pallet, weighs 80 pounds. The cavity of the shielded cask contains a leak tight, 2R. type, steel insert, shown on GE Draving Pio.151F443, Rev. 5 or $135 \mathrm{C} 5982$, Rev. 4 , or 10503830 , P. 1. \& (the latter to be used with the liner shown on 153C4613, Prev. 1). Tha gross weight of the loaded package is approximately 285 pounds. 
age 2 - Certificate No. 6697 - Revision No. 5 - Docket No. 71-6697

5. (a) Packaging (continued)

(3) Drawings

The package is constructed in accordance with the following General Electric Company Drawing Nos.: 277E696, Rev. 6; $277 \mathrm{E} 712$, Rev. 6; 174F482, Rev. 5; 289E795, Rev. 3; 195F169, Rev. 2; 289E796, Rev. 5; 161F443, Rev. 5; or 135C5982, Rev. 4; or 10603830, Rev. 8 with 153C4613, Rev. 1.

(b) Contents

(i) Type and form of material

Radioactive materials as solids.

(2) Maximum quantity of material per package

Greater than Type A quantities of radioactive material with the decay heat load not exceeding 50 watts. Plutonium in excess of twenty (20) curies per package must be in the form of metal, metal alloy or reactor fuel elements.

6. Prior to each shipment, the package lid Neopoene gasket shall be inspected. The gasket shall be replaced with a new Neoprene gasket if inspection shows any defects or every twelve (12) months, whichever occurs first. In each shipment, a new Viton 0 -ring shall be used to seal the $2 R$ type insert.

7. The $2 R$ type insert shall be pretested to ensure leak tightness prior to each use in accordance with Attachment D of General Electric's letter dated November 29, 1979.

8. The radiation dose level shall not exceed 1000 millirem per hour, at a distance of 3 feet from the surface of the depleted uranium cask, when the wooden protective jacket is not in place.

9. The package authorized by this certificate is hereby approved for use under the general license provisions of 10 CFR $571.12(\mathrm{~b})$.

10. Expiration date: February 28, 1985. 
III. 13

III. COMMERCIAL PACKAGES SHIPPED FROM ORNL

(NRC or DOT Approved)

J. L. SHEPHERD AND ASSOCIATES 
Form NRC-618

(12.73)

10 CFR 71
U.S. NUCLEAR REGULATORY COMMISSION CERTIFICATE OF COMPLIANCE

For Radioactive Materials Packages

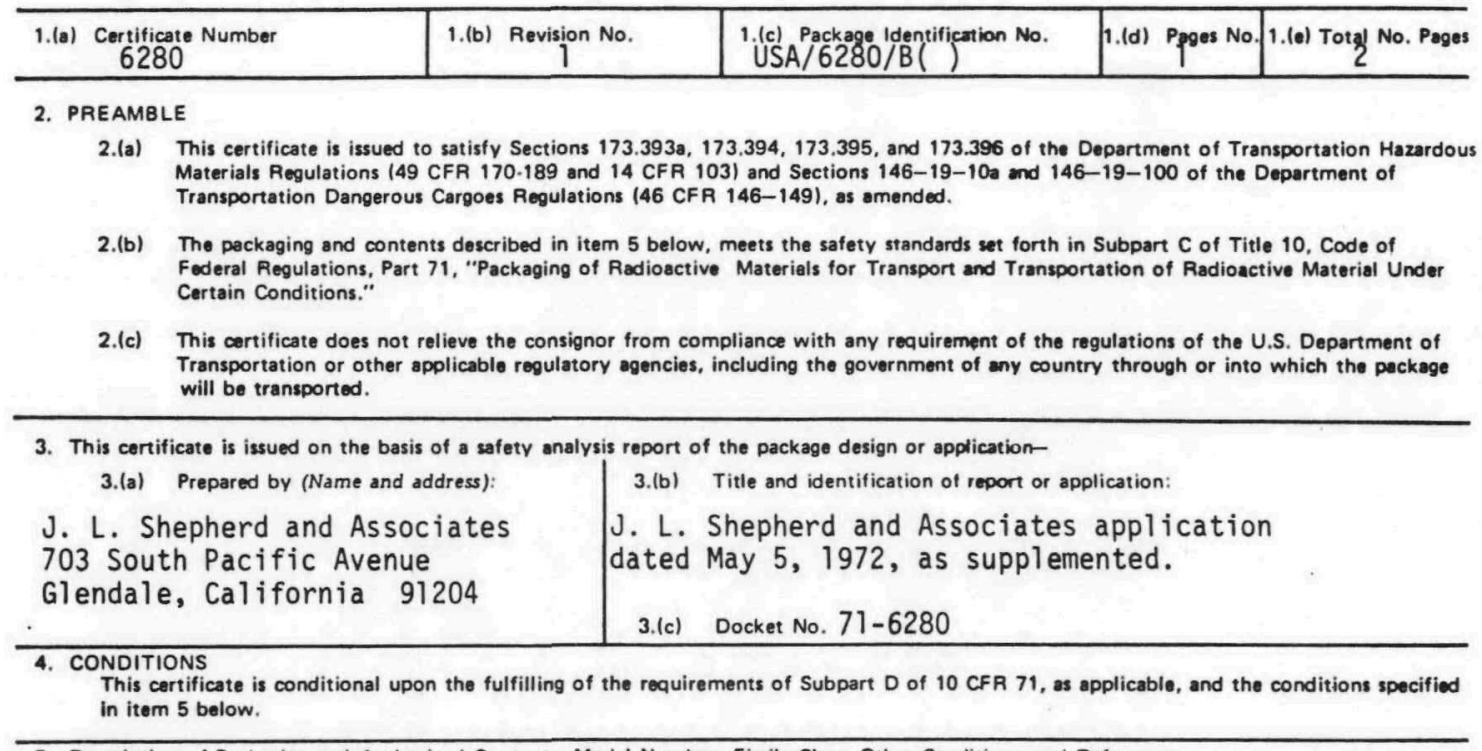

5. Description of Packaging and Authorized Contents, Model Number, Fissile Class, Other Conditions, and References:

(a) Packaging

(1) Model No.: A-0109 Irradiator in A-0117 Overpack

(2) Description

The packaging consists of an inner, lead-filled, steel weldment (Model A-0109 irradiator) enclosed within an outer protective enclosure (Model A-0117 overpack). The irradiator is a right cylinder, 31 inches diameter by 36 inches high, with a bolted top plug closure. The overpack is a double-walled steel cylinder enclosing a shock abosrbing and thermal insulation core of glue-bonded layers of balsa wood ( $11 \mathrm{lbs} / \mathrm{cu}$. $\mathrm{ft}$. density, 12 inches thick on the sides). The irradiator is held in place in the overpack by steel spacers attached to a $1 / 2$ inch thick steel plate at each end. The void between the irradiator and inside wall of the overpack is filled with hardwood spacers. The overpack cover is secured by $30-5 / 8$ inch diameter bolts. The dimesions of the package are 50.5 inches diameter by 73 inches long. The weight of the shielded irradiator is 7,000 lbs. and the weight of the overpack is 3,400 lbs., totaling 10,400 lbs.

(3) Drawings

The overpack and irradiator are constructed in accordance with J. L. Shepherd and Associates Drawings Nos.: A-0109-A1, A-0109-10, $\mathrm{A}-0109-20, \mathrm{~A}-0117 \mathrm{~B}, \mathrm{~A}-0117 \mathrm{C}$, and A-0117-C1. 
Page 2 - Certificate No. 6280 - Revision No. 1 - Docket No. 71-6280

5. (b) Contents

(1) Type and form of material

Cobalt 60 as cobalt wire encapsulated and heliarc welded in a stainless steel tube. The source is further encapsulated in an annular capsule approximately 6 inches in diameter by 6.43 inches long and sealed by heliarc welding. The cobalt 60 must meet the special form requirements of 10 CFR 71 .

(c) Maximum quantity of material per package

30,000 curies

6. The overpack must be modified by the addition of not less than $14-1 / 4$ inch diameter vent holes in the outer shell (two each in the top cap and cap side, two in the bottom, and in two side tiers of 4 holes each, at $90^{\circ}$ separation, with each tier located about one foot from each end). The holes must be sealed to prevent the inleakage of water but not so as to affect their capability of venting in the event of fire.

7. The package authorized by this certificate is hereby approved for use under the general license provisions of Paragraph $71.12(\mathrm{~b})$ of 10 CFR Part 71.

8. Expiration date: November 30, 1979.

\section{REFERENCES}

J. L. Shepherd and Associates' application dated May 5, 1972.

Supplement dated: June 27, 1972.

FOR THE U.S. NUCLEAR REGULATORY COMMISSION

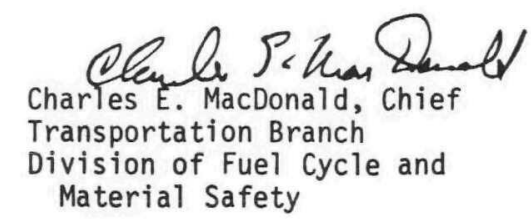

Date: MAR 291971 
○

O

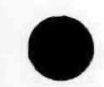


III. 17

III. COMMERCIAL PACKAGES SHIPPED FROM ORNL

(NRC or DOT Approved)

GAMMA INDUSTRIES 
RNL Photo 2540-78

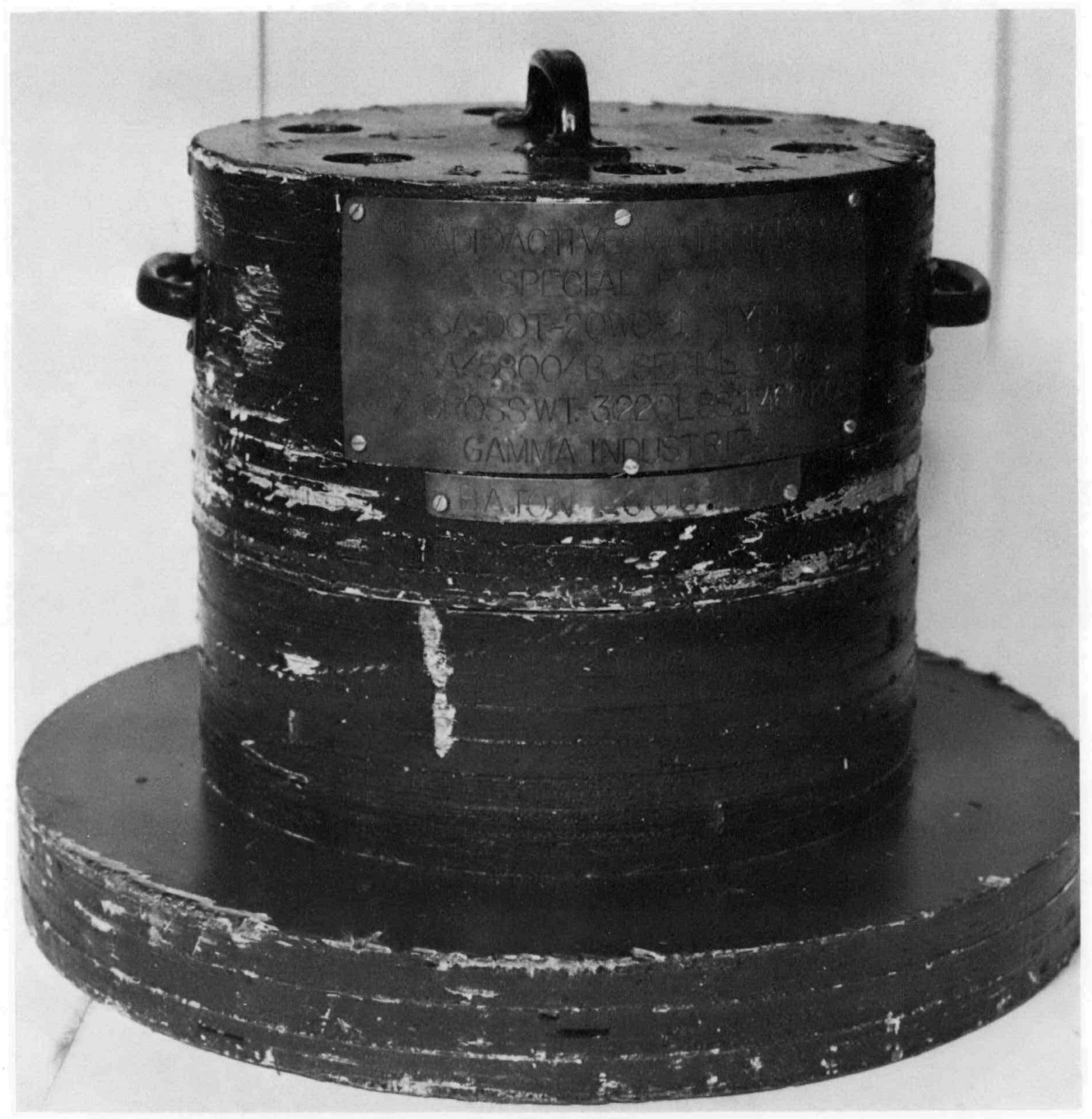

Gamma Industries DOT 20WC-1

Type B 


$\begin{aligned} \text { 1. } & \text { H. C. Austin } \\ \text { 2. } & \text { H. Bailey } \\ \text { 3. } & \text { J. E. Bigelow } \\ \text { 4-5. } & \text { G. H. Burger } \\ \text { 6. } & \text { C. D. Cagle } \\ \text { 7. } & \text { G. C. Cain } \\ \text { 8. } & \text { F. N. Case } \\ \text { 9. } & \text { R. L. Cline } \\ \text { 10. } & \text { J. A. Cox } \\ \text { 11. } & \text { J. R. DeVore } \\ \text { 12. } & \text { J. H. Evans } \\ \text { 13. } & \text { J. R. Gisse1 } \\ \text { 14. } & \text { H. R. Gwinn } \\ \text { 15. } & \text { K. W. Haff } \\ \text { 16. } & \text { S. S. Hurt } \\ \text { 17. } & \text { V. M. Johnson } \\ \text { 18. } & \text { R. D. Johnston } \\ \text { 19. } & \text { E. M. King } \\ 20 . & \text { L. J. King } \\ \text { 21. } & \text { F. F. Knapp }\end{aligned}$

22. E. Lamb

23. R. V. McCord

24. J. H. Moore

25. C. L. Ottinger

26. J. R. Parrott

27. M. E. Ramsey

28. J. E. Ratledge

29-34. R. W. Schaich

35. R. D. Seagren

36. J. A. Setaro

37. L. B. Shappert

38. M. R. Skidmore

39. W. R. Tatum

40. A. A. Walls

41. F. V. Williams

42-43. Central Research Library

44. Document Reference Section

45-54. Laboratory Records Department

55. Laboratory Records - RC

56. ORNL Patent office

EXTERNAL DISTRIBUTION

57. L. G. Blacok, DOE, Supply Div., ORO

58. H. N. Culver, DOE, ORO

59. R. E. Harris, DOE, ORO

60. Assistant Manager, Energy Research and Development, DOE, ORO

61. W. A. Pryor, DOE, ORO

62. W. H. Travis, DOE, ORO

63. Safety and Health Protection Branch, DOE, ORO

64-224. Given distribution as shown in TID-4500 under category UC-71 Transportation of Property and Nuclear Materials (25 copies NTIS) 
$D$

$\sigma$

0 


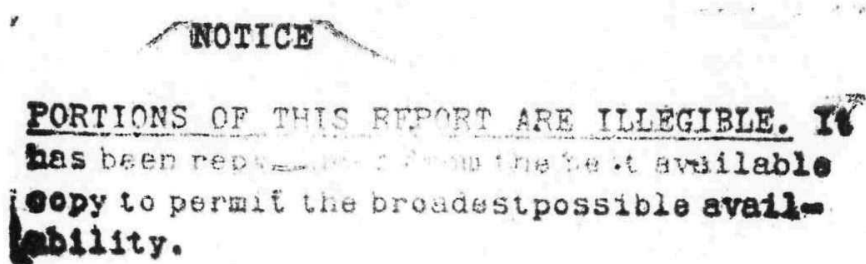

Ability.
ORNL/TM-7179

Dist. Category UC-71

Contract No. W-7405-eng-26

OPERATIONS DIVISION

Radioisotope Department

MASTER

\author{
OAK RIDGE NATIONAL LABORATORY \\ SH I PPING CONTAINERS FOR \\ RADIOACTIVE MATERIALS
}

R. W. Schaich

Date Published: May 1980

NOTICE This document contains information of a preliminary nature. It is subject to revision or correction and therefore does not represent a final report.

OAK RIDGE NATIONAL LABORATORY

Oak Ridge, Tennessee 37830

operated by

UNION CARBIDE CORPORATION

for the

DEPARTMENT OF ENERGY 


\section{Printed in the United States of America. Available from National Technical Information Service \\ U.S. Department of Commerce \\ 5285 Port Royal Road, Springfield, Virginia 22161 NTIS price codes-Printed Copy: A10 Microfiche A01}

This report was prepared as an account of work sponsored by an agency of the United States Government. Neither the United States Government nor any agency thereof, nor any of their employees, makes any warranty, express or implied, or assumes any legal liability or responsibility for the accuracy, completeness, or usefulness of any information, apparatus, product, or process disclosed, or represents that its use would not infringe privately owned rights. Reference herein to any specific commercial product, process, or service by trade name, trademark, manufacturer, or otherwise, does not necessarily constitute or imply its endorsement, recommendation, or favoring by the United States Government or any agency thereof. The views and opinions of authors expressed herein do not necessarily state or reflect those of the United States Government or any agency thereof. 
ORNL TYPE A PACKAGES . . . . . . . . . . . . . . I I.1

I.A DOT-IAEA TYPE A ORNL SHIPPING CONTAINERS . . . . I.A.I

A. Radioactive Liquids and Solids . . . . . . I.A.I

1. Non-Shielded - Non-Returnable . . . . I.A.1

2. Shielded - Non-Returnable . . . . . I.A.5

3. Shielded - Returnable Outer Container . . I.A.8

4. Shielded - Returnable . . . . . . I.A.11

I.B. DOT-IAEA TYPE A ORNL SHIPPING CONTAINERS . . . . I.B.I

B. Radioactive Solids Only . . . . . . . I.B.1

1. Cyclotron Target - 1" Lead ...... . I.B.1

2. Cyclotron Target - 2" Lead ...... I.B.5

3. Cyclotron Target - 4" Lead ...... I.B.7

4. TRU Neutron Shipping Container . . . . I.B.11

I.C DOT-IAEA TYPE A ORNL SHIPPING CONTAINERS . . . I.C.I

C. Radioactive Gases . . . . . . . . . . I.C.1

1. Shielded - Non-Returnable ....... I.C.1

2. Shielded and Non-Shielded - Returnable

Cylinders (10 cc) . . . . . . . . I.C.5

3. Shielded and Non-Shielded - Returnable Cylinders $(50,150,300,500 \mathrm{cc})$. . I.C. 7

4. Shielded and Non-Shielded - Returnable Cylinders $(1000 \mathrm{cc})$. . . . . . . I.C.11

5. Non-Shielded - Non-Returnable (1000 cc) . I. C. 15

6. Shielded Cylinder - Impact Shield . . .

II. ORNL TYPE B PACKAGES . . . . . . . . . . . . . . II.1

II.A RADIOACTIVE GASES . . . . . . . . . . . II.A.1

1. Gas Cylinder Fire and Impact Shield . . . II.A.1

2. SRO-LP 50 Fire and Impact Shield . . . II.A.5

3. Krypton-85 Shipping Container..... II.A.13

II.B. RADIOACTIVE SOLIDS ........... II.B.1

1. DOT 6M .............. . . . . . . . .

2. DOT-20WC-1 ........... . . . II.B.7

3. DOT-20WC-3 . . . . . . . . . II.B.9

4. DOT-20WC-4 ............ . . II.B.11

5. DOT-20WC-5 ............ . . . II.B.15

6. DOT-21WC ............. . . . . . . . 23

7. LiOH Fire and Impact Shield ....... II.B.29

8. Tungsten Shielded Casks ........ II.B.35

9. TRU Curium Shipping Container...... II.B.41 
10. TRU Ten-Ton Californium Shipping Container.......... . . II.B.47

11. D-38 Uranium Shielded Shipping Cask . . II.B.53

12. HFIR Irradiated Fuel Element Cask . . . II.B-59

13. ORNL Loop Transport Cask . . . . . II.B.65

14. HFIR Unirradiated Fuel Element Cask (Outer) ......... II.B.71

15. HFIR Unirradiated Fuel Element Cask (Inner) . . . . . . . . II.B.77

16. ORNL In-Pile Capsule Shipping Cask . . II.B.83

17. ORNL Garden Carrier No. 2 . . . . . II.B.89

18. ORNL Uranium Shielded Shipping Cask . . II.B.95

19. ORNL Foamglass Shipping Container . . . II.B.101

20. Y-12 DT-14 Packaging for Enriched

II.B. 107

21. ORNL Unirradiated Fue1 Shipping Container.......... II.B.113

III. COMMERCIAL PACKAGES SHIPPED FROM ORNL . . . . . . . III.1

1. Technical Operations ............ . III.1

2. General Electric Company . . . . . . . . . III.7

3. J. L. Shepherd and Associates . . . . . . . III.13

4. Gamma Industries . . . . . . . . . . III.17 
I. ORNL TYPE A PACKAGES

Oak Ridge National Laboratory (ORNL) shipping containers for radioactive materials which meet the requirements of the Code of Federal Regulations No. 49 [Department of Transportation (DOT)], and the International Atomic Energy Agency (IAEA) Safety Series No. 6 (1973) for Type A packaging are divided into three categories.
A. Radioactive Liquids and Solids
B. Radioactive Solids
C. Radioactive Gases

The quantities of radioactive material that are approved for shipment by the CFR-49, Transportation, Part 173.389e, in a Type A package are listed in the following chart.

\begin{tabular}{|c|c|}
\hline $\begin{array}{l}\text { Transport group } \\
(\text { see } \S 173.389(\mathrm{~h}))\end{array}$ & $\begin{array}{l}\text { Type A quantity } \\
\text { (in curies) }\end{array}$ \\
\hline I........... & 0.001 \\
\hline II $\ldots \ldots \ldots \ldots \ldots$ & 0.05 \\
\hline III............. & 3 \\
\hline IV $\ldots \ldots \ldots \ldots \ldots$ & 20 \\
\hline $\mathrm{v}, \ldots \ldots \ldots \ldots \ldots$ & 20 \\
\hline vi and viI $\ldots \ldots \ldots$ & 1,000 \\
\hline Special form....... & $20^{a}$ \\
\hline
\end{tabular}

The transport group for each radionuclide can be determined from the following chart (CFR-49, Part 173.390a). 
III. CLASSIFICATION OF RADIOACTIVE MATERIAL

Table I. Classification of Radionuclides into Groups for Transportation Purposes

\begin{tabular}{|c|c|c|c|c|c|c|c|c|c|c|c|c|c|c|c|c|c|}
\hline \multirow{2}{*}{ Element ${ }^{1}$} & \multirow{2}{*}{ Radionuclide 3} & \multicolumn{7}{|c|}{ Transport Group } & \multirow{2}{*}{ Element ${ }^{1}$} & \multirow{2}{*}{ Radionuclide ${ }^{3}$} & \multicolumn{7}{|c|}{ Transport Group } \\
\hline & & I & II & III & IV & $\mathrm{v}$ & VI & VII & & & I & II & III & IV & $\mathrm{v}$ & VI & VII \\
\hline \multirow[t]{2}{*}{ Actinium (89).... } & $A c-227 \ldots \ldots \ldots$ & $\mathrm{X}$ & $\cdots$ & $\cdots$ & $\cdots$ & $\cdots$ & $\cdots$ & $\cdots$ & \multirow[t]{3}{*}{ Californium (98).. } & Cf $-249 \ldots \ldots \ldots$ & $\mathrm{x}$ & $\cdots$ & & $\cdots$ & & . & \\
\hline & $A c-228 \ldots \ldots \ldots$ & $\mathrm{x}$ & $\cdots$ & $\cdots$ & $\cdots$ & $\cdots$ & $\cdots$ & $\cdots$ & & Cf-250........ & $\mathrm{x}$ & $\cdots$ & $\cdots$ & $\cdots$ & $\cdots$ & $\cdots$ & $\cdots$ \\
\hline Aluminum (13).... & $\mathrm{A} 1-26 \ldots \ldots \ldots \ldots$ & $\cdots$ & $\mathrm{x}$ & $\ldots$ & $\cdots$ & $\cdots$ & $\cdots$ & $\ldots$ & & $\mathrm{Cf}-252 \ldots \ldots \ldots$ & $\mathrm{X}$ & $\cdots$ & $\cdots$ & $\cdots$ & $\cdots$ & $\cdots$ & $\cdots$ \\
\hline \multirow[t]{2}{*}{ Americium (95)... } & $\mathrm{Am}-241 \ldots \ldots \ldots$ & $\mathrm{X}$ & $\cdots$ & $\cdots$ & $\cdots$ & $\cdots$ & $\cdots$ & $\cdots$ & Carbon (6)........ & C-14.......... & $\cdots$ & $\cdots$ & $\cdots$ & $\mathrm{X}$ & $\cdots$ & $\cdots$ & $\cdots$ \\
\hline & $\mathrm{Am}-243 \ldots \ldots \ldots$ & $\mathrm{X}$ & $\cdots$ & $\cdots$ & $\cdots$ & $\cdots$ & $\cdots$ & $\cdots$ & \multirow[t]{4}{*}{ Cerium $(58) \ldots \ldots$. } & $\mathrm{Ce}-139 \ldots \ldots \ldots$ & $\cdots$ & $\cdots$ & $\mathrm{x}$ & $\cdots$ & $\cdots$ & $\cdots$ & $\cdots$ \\
\hline \multirow[t]{3}{*}{ Antimony (51).... } & sb-122.......... & $\cdots$ & $\cdots$ & $\cdots$ & $\mathrm{x}$ & $\cdots$ & $\cdots$ & $\cdots$ & & $\mathrm{Ce}-141 \ldots \ldots \ldots$ & $\cdots$ & $\cdots$ & $\cdots$ & $\mathrm{X}$ & $\cdots$ & $\cdots$ & $\cdots$ \\
\hline & Sb-124.......... & $\cdots$ & $\cdots$ & $\mathrm{X}$ & $\cdots$ & $\cdots$ & $\cdots$ & $\cdots$ & & $\mathrm{Ce}-143 \ldots \ldots \ldots$ & $\cdots$ & $\cdots$ & $\ddot{v}$ & $\mathrm{X}$ & $\cdots$ & $\cdots$ & $\cdots$ \\
\hline & $\mathrm{Sb}-125 \ldots \ldots \ldots$ & $\cdots$ & $\cdots$ & $\mathrm{X}$ & $\cdots$ & $\cdots$ & $\cdots$ & $\cdots$ & & $\mathrm{Ce}-144 \ldots \ldots \ldots$ & $\cdots$ & $\cdots$ & $\mathrm{X}$ & 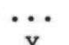 & $\cdots$ & $\cdots$ & $\cdots$ \\
\hline \multirow{3}{*}{ Argon $(18) \ldots \ldots \ldots$} & $\mathrm{Ar}-37 \ldots \ldots \ldots \ldots$ & $\cdots$ & $\cdots$ & $\cdots$ & $\cdots$ & $\cdots$ & $\mathrm{X}$ & $\cdots$ & \multirow[t]{4}{*}{ Cesium (55)...... } & $\mathrm{Cs}-131 \ldots \ldots \ldots$ & $\cdots$ & $\cdots$ & $\cdots$ & $\mathrm{x}$ & $\cdots$ & $\cdots$ & \\
\hline & $\operatorname{Ar}-41 \ldots \ldots \cdots \cdots$ & $\cdots$ & $\mathrm{X}$ & $\cdots$ & $\cdots$ & $\cdots$ & $\cdots$ & $\cdots$ & & $\mathrm{Cs}-132 \ldots \ldots \ldots$ & $\cdots$ & $\cdots$ & $\begin{array}{l}\mathrm{X} \\
\mathrm{x}\end{array}$ & $\cdots$ & $\cdots$ & $\cdots$ & $\cdots$ \\
\hline & $\begin{array}{l}\text { Ar-41 } \\
\text { (uncompressed) }^{2} \text {. }\end{array}$ & & & & & $x$ & & & & $\begin{array}{l}\mathrm{Cs}-134 \mathrm{~m} . \ldots \ldots \ldots \\
\mathrm{Cs}-134 \ldots \ldots \ldots\end{array}$ & $\cdots$ & $\cdots$ & $\begin{array}{l}x \\
x\end{array}$ & $\cdots$ & $\cdots$ & $\cdots$ & $\cdots$ \\
\hline \multirow[t]{4}{*}{ Arsenic (33).... } & As-73........... & $\ldots$ & $\ldots$ & $\ldots$ & $\mathrm{x}$ & $\ldots$ & $\cdots$ & $\cdots$ & & $\begin{array}{l}\mathrm{Cs}-134 \ldots \ldots \ldots \ldots \\
\mathrm{Cs}-135 \ldots \ldots \ldots\end{array}$ & $\cdots$ & $\cdots$ & $\begin{array}{c}x \\
\ldots\end{array}$ & $\ddot{x}$ & $\cdots$ & $\cdots$ & $\ldots$ \\
\hline & As $-74 \ldots \ldots \ldots \ldots$ & $\ldots$ & $\ldots$ & $\ldots$ & $\mathrm{X}$ & .. & $\ldots$ & $\ldots$ & \multirow{4}{*}{ Chlorine (17).... } & Cs-136........ & $\ldots$ & $\ldots$ & $\ldots$ & $\mathrm{x}$ & $\ldots$ & $\ldots$ & $\ldots$ \\
\hline & As-76. . & $\cdots$ & $\cdots$ & $\cdots$ & $\mathrm{x}$ & $\cdots$ & $\cdots$ & $\ldots$ & & Cs $-137 \ldots \ldots \ldots$ & $\ldots$ & $\ldots$ & $\mathrm{x}$ & $\ldots$ & $\ldots$ & $\ldots$ & $\ldots$ \\
\hline & $\cdots$ & $\cdots$ & $\cdots$ & $\cdots$ & $\mathrm{x}$ & .. & $\ldots$ & $\ldots$ & & $\ldots \ldots \ldots \ldots$ & $\ldots$ & $\ldots$ & $\mathrm{x}$ & $\ldots$ & $\ldots$ & $\ldots$ & $\ldots$ \\
\hline Astatine $(85) \ldots$. & $\ldots \ldots$ & $\cdots$ & $\ldots$ & $\mathrm{X}$ & $\ldots$ & $\cdots$ & $\ldots$ & $\ldots$ & & $\ldots \ldots$ & $\ldots$ & $\ldots$ & $\ldots$ & $\mathrm{x}$ & $\ldots$ & $\ldots$ & $\ldots$ \\
\hline \multirow[t]{3}{*}{ Barium $(56) \ldots \ldots$} & $\mathrm{Ba}-131 \ldots \ldots \ldots$ & $\cdots$ & $\cdots$ & $\cdots$ & $\mathrm{x}$ & $\cdots$ & $\cdots$ & $\cdots$ & Chromium (24).... & $\mathrm{Cr}-51 \ldots \ldots \ldots$ & $\cdots$ & $\cdots$ & $\cdots$ & $\mathrm{x}$ & $\cdots$ & $\cdots$ & $\cdots$ \\
\hline & $\mathrm{Ba}-133 . \ldots \ldots \ldots$ & $\cdots$ & $\mathrm{X}$ & $\cdots$ & $\cdots$ & $\cdots$ & $\cdots$ & $\ldots$ & \multirow{5}{*}{ Cobalt (27)...... } & Co-56......... & $\cdots$ & $\cdots$ & $\mathrm{X}$ & $\cdots$ & $\cdots$ & $\ldots$ & $\cdots$ \\
\hline & $\ldots \ldots \ldots$ & $\cdots$ & $\cdots$ & $\mathrm{X}$ & $\cdots$ & $\cdots$ & $\cdots$ & $\cdots$ & & Co-57.......... & $\cdots$ & $\cdots$ & $\cdots$ & $\mathrm{x}$ & $\cdots$ & $\ldots$ & ... \\
\hline Berkelium (97)... & $249 \ldots \ldots \ldots$ & $\mathrm{X}$ & $\cdots$ & $\cdots$ & $\cdots$ & $\cdots$ & $\cdots$ & $\cdots$ & & $8 \mathrm{~m} \ldots \ldots \ldots$ & $\cdots$ & $\cdots$ & $\cdots$ & $\mathrm{x}$ & $\cdots$ & $\cdots$ & $\cdots$ \\
\hline Beryllium (4)... & $\mathrm{Be}-7 \ldots$ & $\cdots$ & $\cdots$ & $\cdots$ & $\mathrm{x}$ & $\cdots$ & $\cdots$ & $\cdots$ & & $\cdots \cdots$ & $\cdots$ & $\cdots$ & $\cdots$ & $\mathrm{x}$ & $\cdots$ & $\cdots$ & $\cdots$ \\
\hline \multirow[t]{5}{*}{ Bismuth $(83) . . .}$. & $\mathrm{Bi}-205 \ldots$ & $\cdots$ & $\cdots$ & $\mathrm{X}$ & $\cdots$ & $\cdots$ & $\cdots$ & $\cdots$ & & Co-60.. & $\cdots$ & $\cdots$ & $\mathrm{X}$ & $\cdots$ & $\cdots$ & $\cdots$ & $\cdots$ \\
\hline & Bi-206......... & $\cdots$ & $\cdots$ & $\cdots$ & $\mathrm{X}$ & $\cdots$ & $\cdots$ & $\cdots$ & \multirow{4}{*}{$\begin{array}{l}\text { Copper }(29) \ldots \ldots \\
\text { Curium }(96) \ldots \ldots\end{array}$} & $\mathrm{Cu}-64 .$. & $\cdots$ & $\cdots$ & $\cdots$ & $\mathrm{x}$ & $\cdots$ & $\cdots$ & $\cdots$ \\
\hline & Bi-207.......... & $\cdots$ & $\cdots$ & $\mathrm{X}$ & $\cdots$ & $\cdots$ & $\cdots$ & $\cdots$ & & $\mathrm{Cm}-242 \ldots \ldots \ldots$ & $\mathrm{X}$ & $\cdots$ & $\cdots$ & $\cdots$ & $\cdots$ & $\cdots$ & $\cdots$ \\
\hline & Bi-210......... & $\cdots$ & $\mathrm{x}$ & $\cdots$ & $\cdots$ & $\cdots$ & $\cdots$ & $\cdots$ & & $\mathrm{Cm}-243 \ldots \ldots \ldots$ & $\mathrm{X}$ & $\cdots$ & $\cdots$ & $\cdots$ & $\cdots$ & $\cdots$ & $\cdots$ \\
\hline & $B i-212 \ldots \ldots \ldots$ & $\cdots$ & $\cdots$ & $\mathrm{X}$ & $\cdots$ & $\cdots$ & $\cdots$ & $\cdots$ & & $-244 \ldots \ldots \ldots$ & $\begin{array}{l}x \\
x\end{array}$ & $\cdots$ & $\cdots$ & $\cdots$ & $\cdots$ & $\cdots$ & \\
\hline \multirow[t]{2}{*}{ Bromine (35)..... } & $\mathrm{Br}-77 \ldots$ & $\cdots$ & $\cdots$ & $\mathrm{X}$ & $\cdots$ & $\cdots$ & $\cdots$ & $\cdots$ & \multirow{4}{*}{ Dysprosium $(66) \ldots$} & $\mathrm{Cm}-245 \ldots$ & $\begin{array}{c}\mathrm{X} \\
\mathrm{y}\end{array}$ & $\cdots$ & $\cdots$ & $\cdots$ & $\cdots$ & $\cdots$ & $\cdots$ \\
\hline & $\mathrm{Br}-82 \ldots \ldots \cdots \cdots$ & $\cdots$ & $\cdots$ & $\cdots$ & $\begin{array}{l}\mathrm{X} \\
\mathrm{X}\end{array}$ & $\cdots$ & $\cdots$ & $\cdots$ & & $\mathrm{Cm}-246 \ldots \ldots$ & $\mathrm{X}$ & $\cdots$ & $\ddot{x}$ & $\cdots$ & $\cdots$ & $\cdots$ & $\cdots$ \\
\hline \multirow{2}{*}{ Cadmium (48).... } & $\mathrm{Cd}-115 \mathrm{~m} . \ldots \ldots \ldots$ & $\cdots$ & $\cdots$ & $\ddot{x}$ & $\begin{array}{c}\Lambda \\
\cdots\end{array}$ & $\cdots$ & $\cdots$ & $\ddot{m}$ & & $\begin{array}{l}\text { Dy }-154 \ldots \ldots \ldots \\
\text { Dy-157......... }\end{array}$ & $\cdots$ & $\cdots$ & $\begin{array}{l}x \\
x\end{array}$ & $\cdots$ & $\cdots$ & $\cdots$ & $\ddot{m}$ \\
\hline & $\mathrm{Cd}-115$ & $\cdots$ & $\cdots$ & $\ldots$ & $\mathrm{x}$ & $\cdots$ & $\ldots$ & & & Dy-165......... & $\ldots$ & $\ldots$ & $\cdots$ & $\mathrm{x}$ & $\ldots$ & $\ldots$ & \\
\hline \multirow{3}{*}{ Calcium (20)..... } & $\mathrm{Ca}-45 \ldots$ & $\cdots$ & ... & $\cdots$ & $\mathrm{x}$ & ... & $\ldots$ & & & Dy-166... & . & $\cdots$ & $\cdots$ & $\mathrm{x}$ & ... & $\cdots$ & \\
\hline & $\mathrm{Ca}-47 \ldots \ldots \ldots \ldots$ & $\cdots$ & $\cdots$ & $\cdots$ & $\mathrm{x}$ & $\cdots$ & $\cdots$ & & Erbium $(68) \ldots \ldots$ & Er-169... & $\cdots$ & $\cdots$ & $\cdots$ & $\mathrm{X}$ & $\cdots$ & $\cdots$ & $\cdots$ \\
\hline & & & & & & & & & & $\operatorname{Er}-171 \ldots \ldots \ldots$ & $\cdots$ & $\cdots$ & $\cdots$ & $\mathrm{x}$ & $\cdots$ & $\cdots$ & $\cdots$ \\
\hline
\end{tabular}


II.B. 3

ORNL-DWG 76-13675R

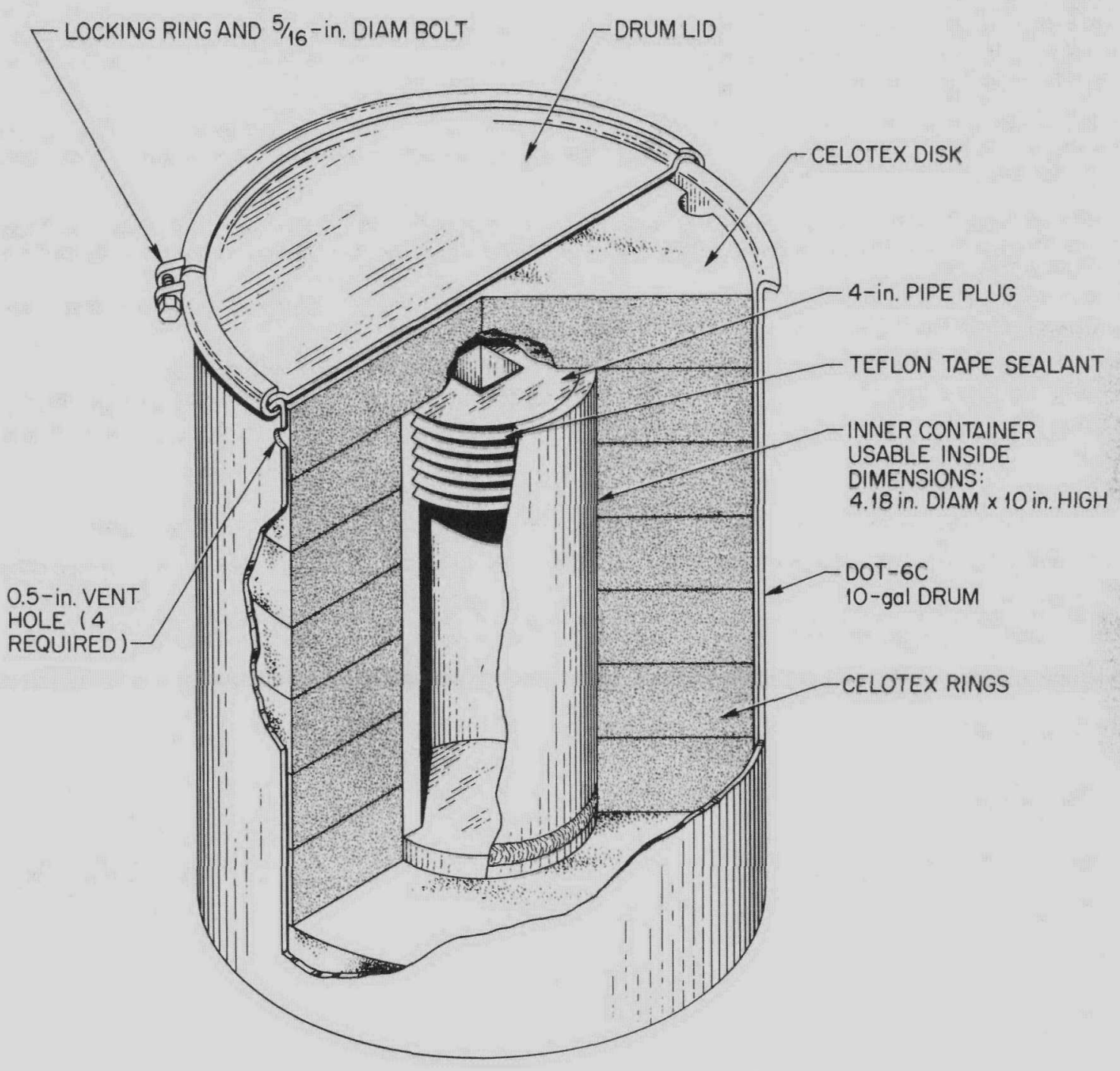

TYPICAL ASSEMBLY DETAIL, $10 \mathrm{gal}$ SIZE DOT-6M WEIGHT-6O Ibs, TYPE B 
Form NAC 618

(12.73)

10 CFA 71
U.S. NUCLEAR REGULATORY COMMISSION CERTIFICATE OF COMPLIANCE

For Radibective Materials Packages

\begin{tabular}{|c|c|c|c|c|}
\hline $\begin{array}{l}\text { 1.(a) Certificate Number } \\
5908\end{array}$ & 1.(b) Remition No. & $\begin{array}{l}\text { 1. (c) Package Identification No. } \\
\text { USA/5908/B( )F }\end{array}$ & 1.(d) Paos No. & $\begin{array}{l}\text { 1.(e) Total No. Peges } \\
3\end{array}$ \\
\hline
\end{tabular}

2. paeamble

2.a) This cartificate is issuad to satisfy Sections 173.393., 173.394, 173.395. and 173.396 of the Department of Transportation Hazardoua Materials Regulations (49 CFR 170-189 and 14 CFR 103) and Sections 146-19-10a and 146-19-100 of the Depertment of Transportation Dangerous Cargoes Regulations (46 CFR 146-149), as anended.

2.(b) The pockaging and comtens described in item 5 below, meers the safery reandards set forth in Subourt C of Tite 10, Code of Federal Regulatiom, Part 71. "Packeging of Aediosctive Materials for Traneport and Transportation of Radionetive Material Under Certain Conditions."

2.lel This certificate does not relieve the consignor from complience with amy requirement of the regularions of the U.S. Depertment of Transportation or other applicable regulatory. apencies, including the government of any country through or into which the peckage will be transported.

1. This certificate is isued on the basis of a satery nendysis report of the packape design or spolication-

3(a) Prepared by (Name and addrese):

The Babcock \& Wilcox Company

609 N. Warren Avenue

Apollo, PA 15613 3.(b) Title and identification of report or application:

Nuclear Materials and Equipment Corporation application dated May 3, 1974, as" supplemented.

3.(c) Docker No. 71-5908

4. CONDITIONS

This certificate is conditional upon the fulfilling of the requirements of Subper D of 10 CFR 71, as applicable, and the conditions specified in item 5 below.

5. Description of Packaging and Authorizad Contents, Model Number, Fiasile Class, Orner Conditions, and Roferences:

(a) Packaging

(1) Model No.: DOT-6M Type B

(2) Description

Metal packaging as described and constructed in accordance with DOT Specification 6M (49 CFR \$178.104).

(b) Contents

(1) Type and form of material

(i) Solid radioactive materials which will not decompose at temperatures up to $250^{\circ} \mathrm{F}$. Carbide compounds are not authorized; or

(ii) $\mathrm{UO}_{2}$ or $\mathrm{UO}_{2}$ mixtures in the form of powder or compact pellets; or

(iii) Plutonfum nitrate or uranyl nitrate solution in flame sealed glass ampoules or screw top plastic vials, each within one or more additional plastic vials with taped lids, and within a sealed product can or polyethylene bottle containing a sufficient amount of vermiculite to absorb twice the liquid contents present; or 
II.B. 5

Page 2 - Certificate No. 5908 - Revision No. 8 - Docket No. 71-5908

(b) Contents (continued)

(1) Type and form of material (continued)

(iv) Plutonium sources in excess of twenty (20) curies per package must be at least double encapsulated in a metal capsule such that the sources meet special form criteria defined in 10 CFR $\$ 71.4(0)$.

Inner and outer capsules are individually leak tested during fabrication per ANSI N542-1977, procedure A2.2.3 (He pressure bubble test), or equivalent.

(2) Maximum quantity of material per package and fissile class

(i) For the material described in 5.(b)(1)(i), the maximum fissile material and maximum hydrogen per package for Fissile Class I is as follows:

Fissile

Material

U-235

$\mathrm{Pu}$

U-233
Maximum fissile material per package, kilograms

1.6

$0.9^{*}$

0.5
Hydrogen Material per package, grams

20

11

6.4

ॠBecause of the 10 watt thermal decay heat limitation, the limit for Pu-238 is 0.02 kilograms. Plutonium in excess if twenty (20) curies per package must be in the form of metal, metal alloy or reactor fuel elements.

(ii) For the material described in 5.(b)(1)(i) the maximum U-235 loading for uranium bearing materials with an $H / X \leq 3$ and the minimum transport index to be assigned to each package for Fissile Class II is as follows

\begin{tabular}{l} 
Maximum \\
Kgs U-235 \\
\hline
\end{tabular}

\section{2}

5.4

7.3

9.1

\section{Minimum \\ Transport Index}

0.1

0.2

0.5

1.0

(iii) For the material described in 5 .(b)(1)(ii) the maximum quantity of $U-233$ is 500 grams at an $H / U$ ratio not to exceed 20 , as Fissile Class III with a limit of 51 packages per shipment. The package size shall not be less than 55 gallons.

(iv) For the material described in 5.(b)(1)(iii) the maximum quantity of material is not to exceed $20 \mathrm{Ci}$ radioactivity and $40 \mathrm{ml}$ of solution. Fissile material shall not exceed 10 grams.

(v) For the material described in 5.(b)(1)(iv) the maximum quantity of plutonium is $100 \mathrm{Ci}$. 
Page 3 - Certificate No. 5908 - Revision No. 8 - Docket No. 71-5908

6. Two steel through bolts may be installed between the lid and bottom of the steel drums.

7. Venting may be provided by a 1-inch diameter hole in the drum lid backed by a minimı $1 / 2-$ inch thick Cerafelt refractory pad.

8. Maximum decay heat per package shall not exceed ten (10) watts.

9. The package authorized by this certificate is hereby approved for use under the general license provisions of 10 CFR $\$ 71.12(\mathrm{~b})$.

10. Expiration date: February 28, 1986.

\section{REFERENCES}

References Required for All Contents Except Contents Described in 5. (b)(1)(iv)

Nuclear Materials and Equipment Corporation application dated May 3, 1974.

Additional References Required for Contents Described in 5.(b)(1)(ii)

Westinghouse Electric Corporation supplement (WAPD-RS(CC)-620) dated May 8, 1973.

DOE, NR supplement dated March 28, 1979.

Additional Reference Required for Contents Described in $5 .(b)(1)$ (iii) and 5. (b)(2)(iv)

Allied Chemical Corporation, Report No. ICP-1061, December 1974.

Reference Required for Contents Described in 5.(b)(1)(iv)

Monsanto Research Corporation application dated January 10, 1980.

FOR THE U.S. NUCLEAR REGULATORY COMMISSION

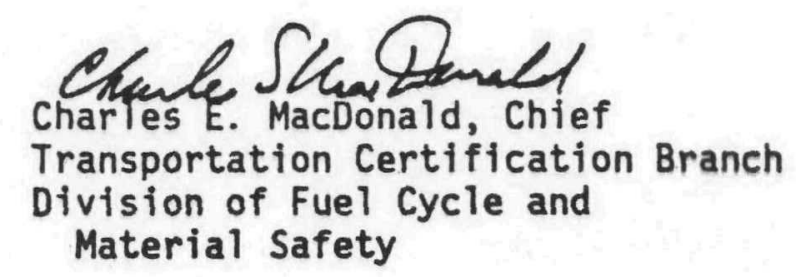

Date: FEB 031981

Revised $9 / 1 / 81$ 
c. This certificate does not relieve any consignor or carrier from compliance with any requirement of the Government of any country through or into which the package is to be transported.

V. Marking and Labeling - The package must bear the marking USA/5787/B( )F as well as the other marking and labels prescribed by the USA Regulations.

VI. Expiration Date - This certificate, unless renewed, expires on January $31,1981$.

This certificate is issued in accordance with the requirements of the IAEA and USA Regulations and in response to the November 25, 1975, petition by the U. S. Energy Research \& Development Administration, Oak Ridge, Tennessee, and in consideration of the associated information provided in USERDA, Oak Ridge Certificate AEC-OR USA/5787/BLF (Append1x A).

Certified by:

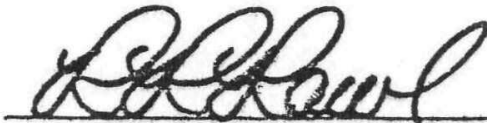

R. R. Rawl, Health Fhysicist

Office of Hazardous Materials Regulation

U. S. Department of Transportation

Washington, D. C. 20590

1"Safety Series No. 6, Regulations for the Safe Transport of Radioactive Materials, 1967 Edition" published by the International Atomic Energy Agency (IAEA), Vienna, Austria.

21itle 49, Code of Federal Regulations, Parts 100-199, USA.

This certificate supersedes in its entirety DOT Special Permit 5787

with respect to international shipments.

Revision 1 issued to extend expiration date in response to the January 19, 1979, petition by the Department of Energy, Oak Ridge, TN. 
II.B. 58

DOE Form EV 618

10 CFR?

U.S. DEPARTMENT OF ENERGY

CERTIFICATE OF COMPLIANCE

For Radioactive Materiais Packages

\begin{tabular}{l|l|c|c|c|}
\hline $\begin{array}{l}\text { 1a. Certificate Number } \\
5787\end{array}$ & $\begin{array}{c}\text { 1b. Revision No. } \\
1\end{array}$ & $\begin{array}{c}\text { 16. Package Identification No. } \\
\text { USA/5787/BLF (DOE-OR) }\end{array}$ & $\begin{array}{c}\text { 1d. Page No. } \\
1\end{array}$ & $\begin{array}{c}\text { 18. Totai No. Pages. } \\
2\end{array}$ \\
\hline
\end{tabular}

2. PREAMBLE

2a. This cartificate is issued to satisfy Sections 173.393a, 173.394, 173.395, and 173.396 of the Department of Transportation Hazardous Materiais Regulations (49 CFR 170-189).

2b. The packaging and contents described in itern 5 below, meets the safety standards set forth in Subpart C of Title 10, Code of Federai Regulations, Part 71 , "Packaging of Radioactive Material for Transport and Transportation of Radioactive Material Under Certain Conditions."

2c. This certificate does not relieve the consignor from compliance with any requirement of the regulations of the U.S. Department of Transportation or other applicable regulatory agencies, including the government of any country through or into which the package will be transported.

3. This certificate is issued on the basis of a safety analysis report of the package design or application-

(1) Prepared by (Name and address):

Oak Ridge National Laboratory

Post Office Box $\mathrm{x}$

Oak Ridge, Tennessee 37830
(2) Title and Identification of report or application: Safety Analysis Report for Packaging (SARP) of the Oak Ridge National Laboratory Shipping Cask D-38 Report ORNL-5406

4. CONDITIONS

This certificate is conditional upon the fulfilling of the requirements of Subpart D of 10 CFR 71, as applicable, and the conditions specified in item 5 beiow.

5. Description of Pacxaging and Authorized Contents, Model Number, Fissile Class, Other Conditions, and References:

(a) Packaging:

(1) Model: D-38 Shipping Cask

(2) Description:

Packaging for transport of fissile and large quantities of radioactive material as solids including mixed fission products, fuel elements, and waste, which are contained within inner DOT Special Form Containers or meet Special Form encapsulation. Plutonium is doubly contained.

The inner cavity of the cask is a 300 Series Stainless Steel Schedule 40 pipe with inside dimensions 6-1/16 in. diameter $\times 13-13 / 16$ in. high. The cuter shel: is a 300 Series Stainless Steel Schecule 30 pipe $20-1 / 2$ in. high. Shielding consists of depleted uranium metal with a thickness of 2-3/4 in. The top opening plug is held in place by eighteen $1 / 3-i n$. studs equipped with nuts. The plux is sealed with a neoprene gasket. The cask is mounted on a 14-in. square $x$ $5 / 8-i n$. thick base plate. Six of the studs are extra long so that a protective shroud may be utilized curing transport. The cask is bolted with four l-in. bolts to a 3-ft. square pallett.

The gross weight of the package is $1525 \mathrm{lb}$.

\begin{tabular}{c|c|c|}
\hline 6e. Date of Issuance: July 24, 1981 & 6b. Expiration Date: \\
\hline FOR THE U.S. DEPARTMENT OF ENERGY
\end{tabular}

7a. Address (of DOE (ssuing Office)

U.S. Department of Energy

Post Office Box E

Oak Ridge, Tennessee 37830

7b. Signature, Name, and Title (of DOE Approving Officiall

$$
\text { the thito }
$$

funwilliam H. Travis, Director

Safety \& Environmental Control Division

Revised $9 / 1 / 81$ 


\section{II.B. $58 \mathrm{a}$}

Page 2 of Certificate No. 5787

\section{(3) Drawings}

The cask is described and fabricated in accordance with Union Carbide Corporation, Nuclear Division, Oak Ridge National Laboratory drawings:

M-12133-CD-126E. Rev. 12 and M-12166-CD-022 Rev. 1.

(b) Contents:

Type and form of material:

(1) Solid, large quantity of radioactive materials, fissile and nonfissile, packaged in DOT Specification $2 \mathrm{R}$ inner Container(s) or meeting Special Form. Plutonium will be doubly contained inside the cask. Dry heat load does not exceed 80 watts. Heat loads in excess of 20 watts are shipped "exclusive-use" of vehicle.

(2) Extemal radiation levels will be within the levels prescribed by DOT Regulations, Title 49 CFR 173.393.

(3) Specific limits of contents:

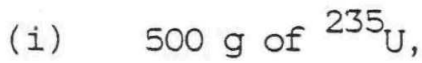

(ii) $350 \mathrm{~g}$ of ${ }^{233} \mathrm{U}$ or ${ }^{239} \mathrm{Pu}$,

(iii) $350 \mathrm{~g}$ of any combination of (i) or (ii) above.

(c) Fissile Class: 
-

○

○ 


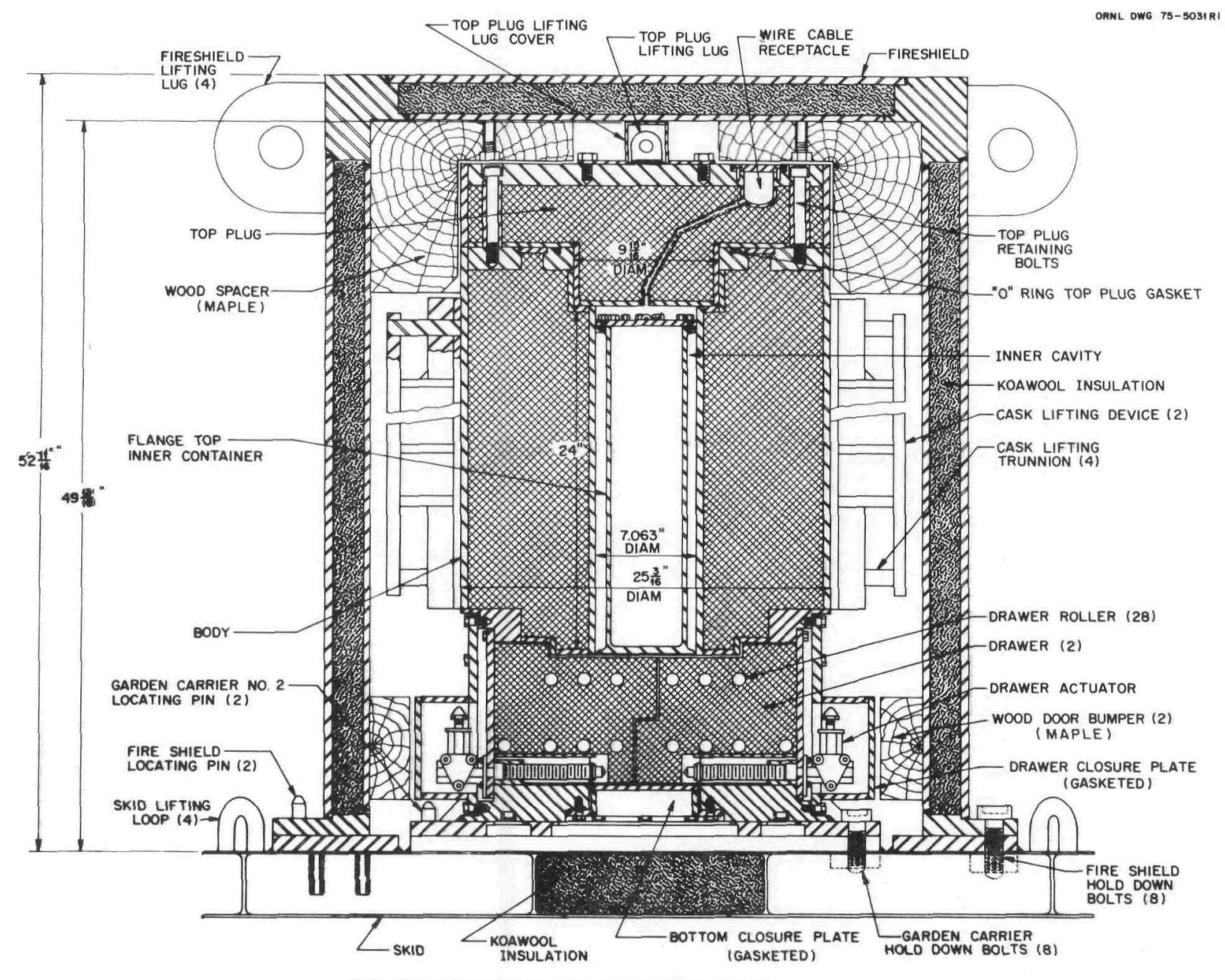

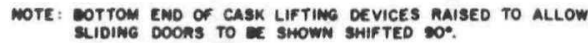

ORNL Garden Carrier No. 2 - Type B 
II.B. 92

DOE Form EV-618

10 CFR 71

U.S. DEPARTMENT OF ENERGY

CERTIFICATE OF COMPLIANCE

For Radioactive Materials Packages

\begin{tabular}{l|c|l|c|c}
\hline $\begin{array}{c}\text { 1a. Certificate Number } \\
6088\end{array}$ & $\begin{array}{c}\text { 1b. Revision No. } \\
1\end{array}$ & $\begin{array}{l}\text { 1c. Package Identification No. } \\
\text { USA/6088/BLF (DOE-OR) }\end{array}$ & $\begin{array}{c}\text { 1d. Page No. } \\
1\end{array}$ & $\begin{array}{c}\text { 1e. Total No. Pages. } \\
2\end{array}$ \\
\hline
\end{tabular}

2. PREAMBLE

2a. This certificate is issued to satisfy Sections 173.393a, 173.394, 173.395, and 173.396 of the Department of Transportation Hazardous Materials Regulations (49 CFR 170-189).

2b. The packaging and contents described in item 5 below, meets the safety standards set forth in Subpart $\mathrm{C}$ of Title 10, Code of Federal Regulations, Part 71, "Packaging of Radioactive Material for Transport and Transportation of Radioactive Material Under Certain Conditions."

2c. This certificate does not relieve the consignor from compliance with any requirement of the regulations of the U.S. Department of Transportation or other applicable regulatory agencies, including the government of any country through or into which the package will be transported.

3. This certificate is issued on the basis of a safety analysis report of the package design or application-

(1) Prepared by (Name and address):

Oak Ridge National Laboratory

Post office Box X

Oak Ridge, Tennessee 37830
(2) Title and Identification of report or application:

Safety Analysis Report for

Packaging (SARP) of the Oak Ridge

National Laboratory Garden Carrier No. 2, Revision 1, Report ORNL-5408/RI

4. CONDITIONS

This certificate is conditional upon the fulfilling of the requirements of Subpart D of 10 CFR 71, as applicable, and the conditions specified

in item 5 below.

5. Description of Packaging and Authorized Contents, Model Number, Fissile Class, Other Conditions, and References:

(a) Packaging

(1) Model: ORNL Garden Carrier No. 2.

(2) Description: A 304L stainless steel encased lead shipping cask.

Packaging for solid radioactive materials as whole or sectioned unirradiated anc irradiated fuel elements, fission products, and wastes. The $25 \mathrm{in.} \mathrm{ODx45}$ in. high cylindrical cask consists of lead, 8-3/16 in. thick, encased in 304L stainless steel. The inner cavity is $7 \mathrm{in.} \mathrm{IDx} 24 \mathrm{in}$. high. Access to the cavity i:: through a plug equipped with an o-ring for top loading and two sliding drawers for bottom opening. Side cover plates for the drawers and the kottom cover plate, which are equipped with gaskets, are bolted to the cask body. The O-rinc and gaskets are made of neoprene.

The radioactive material is contained within a DOT specification $2 \mathrm{R}$ container as specified, which is positioned within an inner container made of 304L stainless steel $5 \mathrm{in.} \mathrm{diameter} \mathrm{schedule} 10$ pipe. The overall dimensions are $6-7 / 8$ in. OD 23-1/2 in. high and the inside dimensions are $5.36 \mathrm{in.} \mathrm{dia.} \times 20-11 / 16 \mathrm{in}$. high. The inner container is covered with a. 10-bolt flange equipped with an 0-ring mac: of neoprene or Silastic.

During shipment, the cask is bolted with $81-1 / 2$ in. $\times 5-1 / 2$ in. long bolts to a $5 \mathrm{ft} . \times 5 \mathrm{ft} . \times 7-1 / 4 \mathrm{in}$. high skid. The cask is covered with a $43 \mathrm{in}$. OD $x$ $52 \mathrm{in.} \mathrm{high} \mathrm{fire} \mathrm{shield} \mathrm{consisting} \mathrm{of} \mathrm{a} 2$ in. thickness of Kaowood insulation

\begin{tabular}{c|c|c|}
\hline 6a. Date of Issuance: & June 30,1981 & 6b. Expiration Date: \\
\hline
\end{tabular}

7a. Address (of DOE Issuing Office)

U.S. Department of Energy

Post office Box E

Oak Ridge, Tennessee 37830

7b. Signature, Name, and Title (of DOE Approving Officiall

Hw Hithte

William H. Travis, Director

Safety \& Environmental Control Division

Revised 9/1/81 
(Babcock \& Wilcox ceramic fiber insulation) encased in steel plate--1/2 in. thick outside and 3/16 in. inside. The void between the top of the cask and inside of the fire shield is partially filled with an annular ring of maple wood. Two maple wood pads fastened to the inside of fire shield are positioned over the drawer cover plates. The fire shield is aligned on the skid by 2 locating pins and is attached to the skid by $81-1 / 2$ in. dia. $\times 3-1 / 2 \mathrm{in.}$ long bolts.

(3) Drawings:

The cask, skid, fire shield, and inner flanged container and modifications are described in Oak Ridge National Laboratory Drawings:

$$
\begin{aligned}
& M-11332-E M-O 10-E-4 \\
& M-11332-E M-O 11-E-3 \\
& M-11332-E M-O 12-E-2 \\
& M-11332-E M-O 13-E-O \\
& M-11332-E M-O 14-E-2 \\
& M-11332-E M-O 15-E-1 \\
& M-11332-E M-O 16-E-0 \\
& M-11332-E M-O 17-D-0 \\
& M-11332-E M-O 18-E-4 \\
& M-11332-E M-O 19-D-0 \\
& M-11332-E M-O 2 O-D-4 \\
& M-12124-C B-O 43-D-2 \\
& M-12166-C D-037-D-2 \\
& M-12166-C D-043-E-1
\end{aligned}
$$

(b) Contents

(1) Type and Form of Material:

Solid, fissile, and large quantity of radioactive materials in the form of unirradiated or irradiated fuel elements, whole or sections, solid fission products, and wastes. The radioactive materials are contained within a DOT Specification 2R inner container as specified in Report ORNL-5408/RI.

(2) Maximum quantity per package:
(a) $500 \mathrm{~g}$ of $233 \mathrm{U}$ or
(b) $350 \mathrm{~g}$ of ${ }^{233} \mathrm{U}$ or Pu or
(c) $350 \mathrm{~g}$ of any combination of fissile material.

(3) Other limitations:

(a) Maximum heat load--100 $\mathrm{W}$.

(b) External radiation dose rates--limited to DOT Regulations, 49 CFR 173.393.

(c) Fissile Class: I 
-

-

○ 
III.13

III. COMMERCIAL PACKAGES SHIPPED FROM ORNL

(NRC or DOT Approved)

J. L. SHEPHERD AND ASSOCIATES 
III. 14

Form NRC.618

(12-73)

20 CFR 71
U.S. NUCLEAR REGULATORY COMMISSION

CERTIFICATE OF COMPLIR.NCE

For Radioactive Materials Packages i.(a) Certificate Number 6280 1.(b) Revision No.

2

1.(c) Package Identification No. USA/6280/B( ) 1.(d) Pages No. 1.(e) Total No. Pages 2

2. PREAMBLE

2.(a) This certificate is issued to satisfy Sections 173.393a, 173.394, 173.395, and 173.396 of the Department of Transportation Mazardou! Materisls Feyulations (49 CFR 170-189 and 14 CFR 103) and Sections 146-19-103 and 146-19-100 of the Department of Transportation Dangerous Cargoes Regulations (46 CFR 146-149), as amended.

2.(b) The packaging and contents described in item 5 below, meets the safety standards set forth in Subpart C of Title 10. Cod 2 of Federal Regulations, Part 71. "Packaging of Radioactive Materials for Transport and Transpurtation of Radioactive Mater'al Under Certain Conditions.:

2.(c) This certificate does not relieve the consignor from compliance with any requirement of the regulations of the U.S. Department of Transportation or other applicable regulatory agencies, including the government of any country through or into which the pacixags. wil! be tratsported.

3. This certificate is issusd on the basis of a safety analysis report of the package design or application-

3.(a) Prepared by (Name and address):

3.(b) Title and identification of report or application:

J. L. Shepherd and Associates

740 Saieni Street

Glendale, CA 91203

J. L. Shepherd and Associates application dated Septembier 5, 1979.

3.(c) Docket No. $71-6280$

4. CONDITIONS

This certificate is conditional uron the fulfilling of the requirements of Subpart D of 10 CFR 71 , as applicable, and the conditions 3pecifisd in irom 5 belom.

5. Description of Packaging and Auth rized Contents, Model Number. Fissile Class, Other Conditions, and References:

(a) Packaging

(1) Model Ho.: A-0109 Irradiator in i-0117 Overpack

(2) Description

The packaging consists of an inner, lead-filled, steel weldment (Model A-0109 irradiator) enclosea within an outer protective enclosure (Model A-0117 overpack). The irradiator is a right cylinder, 3: inch 2 diameter by 36 inches high, with a bolted top plug closure. The overpack is a double-walled steel cylinder enclosing a shoc': abosrbing and thermal insulation core of glue-bonded layers of balsa wood (11 lbs/cu. ft. density, 12 inches thick on the sides). The irradiator is held in place in the overpack by steel spacers attached to a 1/2 inch thick steel plate at each end. The void between the irradiator and inside wall of the overpack is filled with hardwood spacers. The overpack cover is secured by 30-5/8 inch diameter bolts. The dimesions of the package are 50.5 inches diameter by 73 inches long. The weight of the shielded irradiator is 7,000 lbs. and the weight of the overpack is 3,400 lbs., totaling 10,400 lbs.

(3) Drawings

The overpack and irradiator are constructed in accordance with J. L. Shepherd and Associates Drawings Nos.: A-0109-Al, A-0109-10, A-0109-20, A-01178, A-0117C, and A-0117-CT. 
Page 2 - Certificate No. 6280 - Revision No. 2 - Dor.ket No. 71-6280

5. (b) Contents

(1) Type and form of material

Cobalt 60 as cobalt wire encapsulated and heliarc welded in a stainless steel tube. The source is further encapsulated in an annular capsule approximately 6 inches in diameter by 6.43 inches long and sealed by heliarc welding. The cobalt 60 must meet the special form requirements of 10 CFR 71 .

(2) Maximum quantity of material per package

30,000 curies

6. The overpack must be modified by the addition of not less than 14-1/4 inch diameter vent holes in the outer shell (two each in the top cap and cap side, two in the bottom, and in two side tiers of 4 holes each, at $90^{\circ}$ separation, with each tier located about one foot from each end). The holes must be sealed to prevert the inleakage of water but not so as to affect their capability of venting in the event of fire.

7. The package authorized by this certificate is hereby approved for use under the general license provisions of Paragraph 71.12(b) of 10 CFR Part 71.

8. Expiration date: November $30,1984$.

\section{REFERENCES}

J. L. Shepherd ind Associates' application dated September 5, 1979.

FOR THE U.S. NUCLEAR REGULATORY COMMISSIUN

Date: NOV 301975

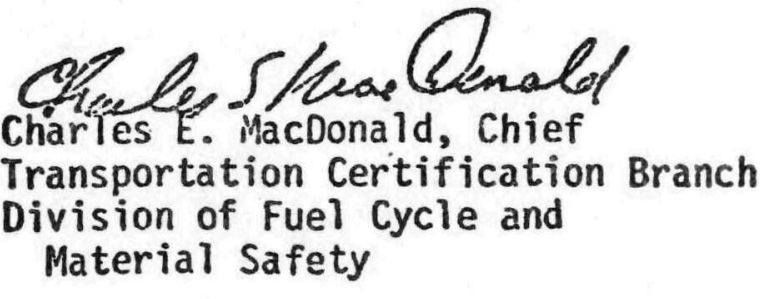

Revised 9/1/81 
○

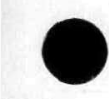


INTERNAL DISTRIBUTION

ORNL/TM-7179

Dist. Category UC-71

\author{
23. E. Lamb \\ 24. R. V. McCord \\ 25. J. M. Miller \\ 26. J. H. Moore \\ 27. E. Newman \\ 28. C. L. Ottinger \\ 29. J. R. Parrott \\ 30. J. E. Ratledge \\ 31-36. R. W. Schaich \\ 37. R. D. Seagren \\ 38. J. A. Setaro \\ 39. L. B. Shappert \\ 40. M. R. Skidmore \\ 41. W. R. Tatum \\ 42. W. E. Terry \\ 43. A. A. Walls \\ 44. F. V. Williams \\ 45-46. Central Research Library \\ 47. Document Reference Section \\ 48-57. Laboratory Records Department \\ 58. Laboratory Records - RC \\ 59. ORNL Patent office
}

\section{EXTERNAL DISTRIBUTION}

60. L. G. Blalock, DOE, Supply Div., ORO

61. R. E. Harris, DOE, ORO

62. J. T. Hummel, DOE, ORO

63. J. A. Lenhard, DOE, ORO

64. W. A. Pryor, DOE, ORO

65. W. H. Travis, DOE, ORO

66. Safety and Health Protection Branch, DOE, ORO

67-227. Given distribution as shown in TID-4500 under category UC-70 Transportation of Property and Nuclear Materials (25 copies NTIS)

Revised $9 / 1 / 81$ 